\title{
A PLAN FOR THE LONG TERM ENVIRONMENTAL ASSESSMENT OF GEOPRESSURED RESOURCE DEVELOPMENT IN THE LOUISIANA GULF COAST REGION
}

E. J. Newchurch, C. F. Bryan, D. P. Harrison, R. A. Muller, R. E. Wilcox

A. L. Bachman, J. P. Newman, K. J. Cunningham, R. K. Hilding, J. A. Rehage

INSTITUTE FOR ENVIRONMENTAL STUDIES

LOUISIANA STATE UNIVERSITY

BATON ROUGE, LOUISIANA

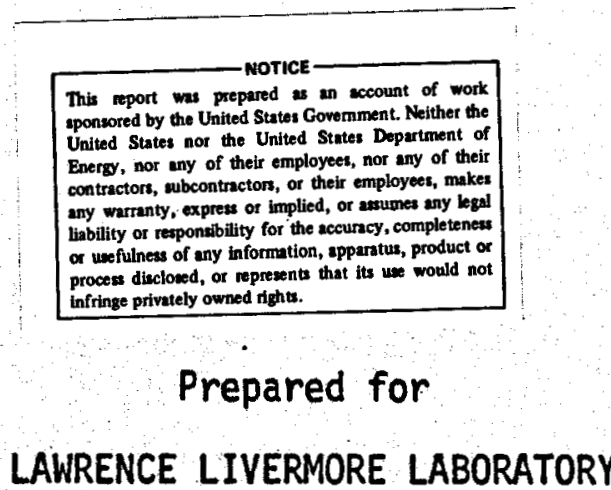

\section{U. S. DEPARTMENT OF ENERGY}

July 15, 1978

"Work performed under the auspices of the U.S. Department of Energy by the Lawrence Livermore Laboratory under contract number W-7405-ENG-48." 


\section{DISCLAIMER}

This report was prepared as an account of work sponsored by an agency of the United States Government. Neither the United States Government nor any agency Thereof, nor any of their employees, makes any warranty, express or implied, or assumes any legal liability or responsibility for the accuracy, completeness, or usefulness of any information, apparatus, product, or process disclosed, or represents that its use would not infringe privately owned rights. Reference herein to any specific commercial product, process, or service by trade name, trademark, manufacturer, or otherwise does not necessarily constitute or imply its endorsement, recommendation, or favoring by the United States Government or any agency thereof. The views and opinions of authors expressed herein do not necessarily state or reflect those of the United States Government or any agency thereof. 


\section{DISCLAIMER}

Portions of this document may be illegible in electronic image products. Images are produced from the best available original document. 


\section{AUTHORS BY DEPARTMENT}

INSTITUTE FOR ENVIRONMENTAL STUDIES

E. J. Newchurch

R. E. WiTcox

DEPARTMENT OF CHEMICAL ENGINEERING

D. P. Harrison

DEPARTMENT OF GEOGRAPHY AND ANTHROPOLOGY

R. A. Muller

R. K. Hilding

DEPARTMENT OF GEOLOGY

K. J. Cunningham

J. A. Rehage

LOUISIANA COOPERATIVE FISHERIES RESEARCH UNIT

C. F. Bryan

OFFICE OF ADVANCED STUDIES AND RESEARCH

A. L. Bachman

SCHOOL OF FORESTRY AND WILDLIFE MANAGEMENT

J. P. Newman 


\section{ACKNOWLEDGEMENTS}

The authors wish to acknowledge the support and guidance of Dr. Joseph D. Martinez, Director of the Institute for Environmental Studies; the technical contributions of Dr. R. L. Thoms, Professor of Civil Engineering; Dr. R. L. Noble, Associate Professor of Forestry and Wildlife Management; Mr. M. F. Hawkins, Project Engineer, Institute for Environmental Studies; Dr. A. J. Lewis, Professor of Geography; and Charles G. Smith, Jr., consulting geologist; the contributions of the office staff including Marie Champagne, Diana Cole, Evelyn Jeansonne, Antonia Moore, Sally Pedrick, and Vicki Pilgrim; and also the assistance of draftswomen Norma Duffy and Suzanne Jambon. 
CONTENTS

Page

List of Figures ........................ ix

List of Tables ............................ xi

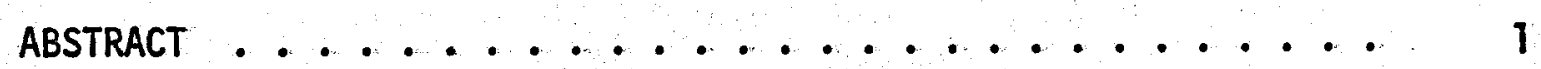

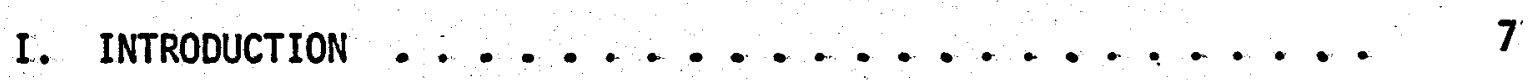

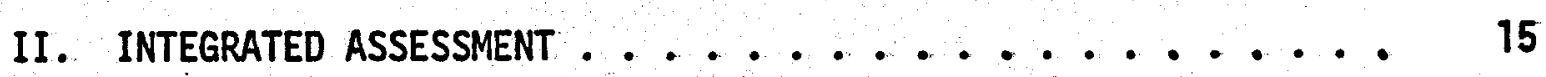

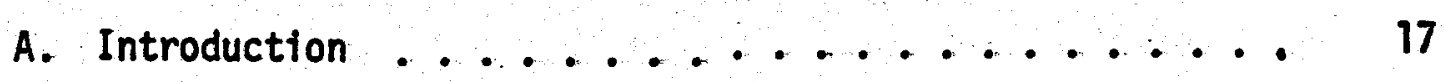

B. Dimensions of the operation ............... 19

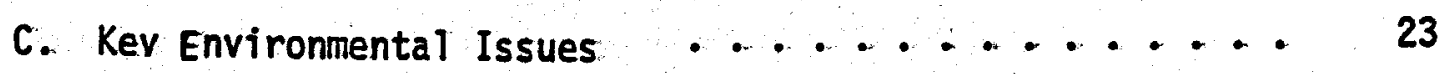

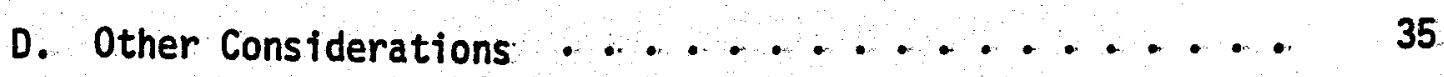

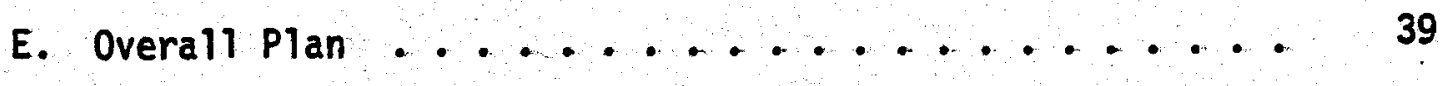

III. DESCRIPTION OF THE PROPOSED ACTIVITY. . . . . . . . 47

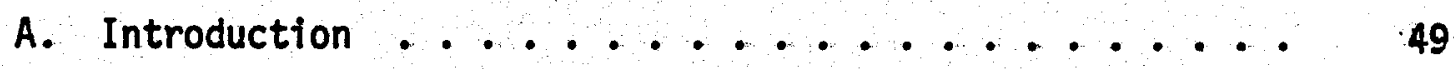

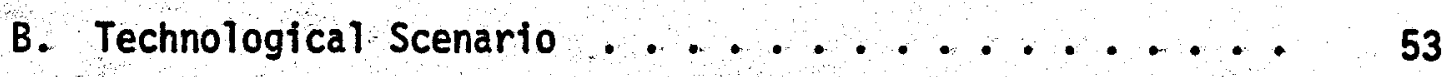

1. General ........................ 53

2. Well Field Development ............ 55

3. Energy Recovery . . . . . . . . . . 55

4. Non-electric Uses of Geopressured Fluids . . . . 61

5. Fluid Disposal _............... 62

C. Resource Characterization ............. 65

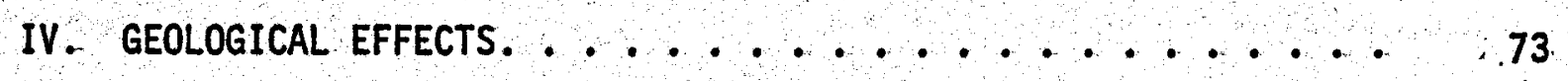

A. Rationale ................ 75

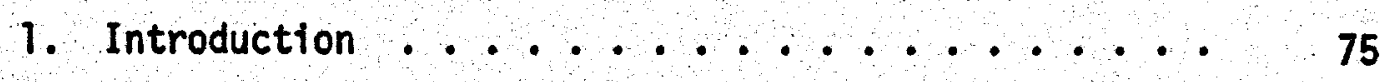

2. Geological Setting: Northern Gulf of Mexico Basin. $\quad 77$ 
3. Potential Environmental Impacts ........ 89

B. Data Requirements and Availability. ......... 99

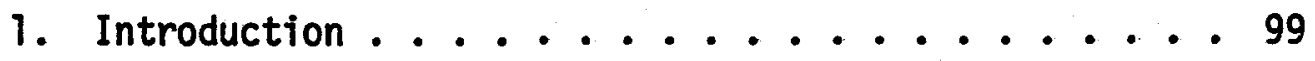

2. Data Requirements ............. 99

3. Data Availability .............. 103

C. Plan for the Acquisition of Data for the Assessment of

Potential Geological Effects ............. 117

1. Introduction .................... 117

2. Level I: Detection .................... 118

3. Level II: Materials Testing .......... 121

4. Level III: Prediction ............. 124

5. Estimated Costs .............. 126

V. AIR QUALITY ..................... . . . 129

A. Rationale ..................... 131

1. Introduction ................ 131

2. Environmental Setting ............ 132

3. Potential Environmental Impacts ........ 148

B. Data Requirements and Availability ........ 155

1. Data Requirements. ............ 155

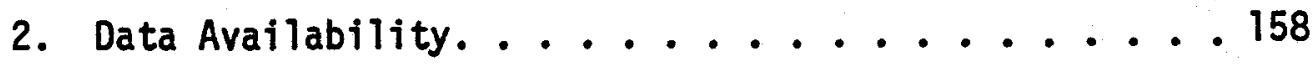

C. Plan for the Acquisition of Data for the Assessment of Potential Environmental Impacts on Air Quality...... 163

1. Fixed Location Monitoring Stations ........ 163

2. Program Costs and Reporting. .......... 165

3. Site Specific Monitoring ........... 166

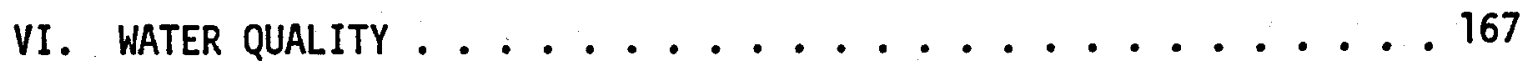

A. Rationale ............................... 169 
1. Introduction. ...................... 169

2. Environmental Setting ............. 170

3. Potential Environmental Impacts......... 185

B. Data Requirements and Availability. ......... 191

1. Data Requirements ............... 191

2. Data Availability .................... 191

C. Plan for Acquisition of Data for the Assessment of

Potential Environmental Impacts on Water Quality. . . 197

1. Surface Water Quality . .............. 197

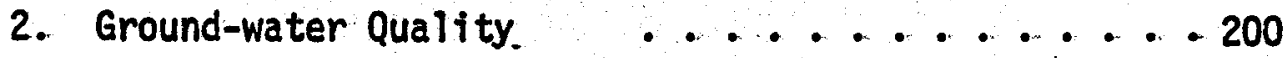

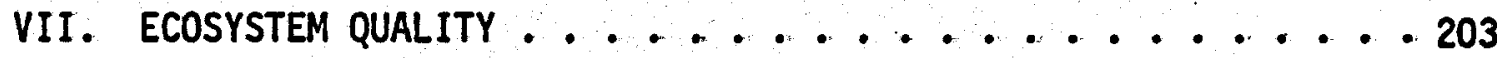

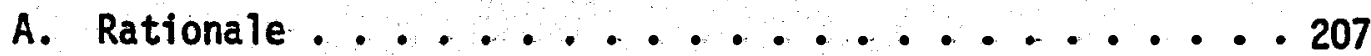

1. Introduction. ....................... 207

2. Environmental Setting . . . . . . . . 207

3. Potential Environmental Impacts . ....... 219

B. Data Requirements and Availability ........233

1. Data Requirements ............. 233

2. Data Avallability .............. 236

C. Plan for the Acquisition of Data for the Assessment of

Potential Environmental Impacts on Ecosystem Quality. . . 243

1. Introduction. ................. 243

2. Offshore Development. ............. 245

3. Coastal Impact. .................. 246

4. Upland and Forest Development .......... 250

VIII. SOCIOECONOMIC AND CULTURAL CONSIDERATIONS . . . . . . . 253

A. Introduction. .................. 255 


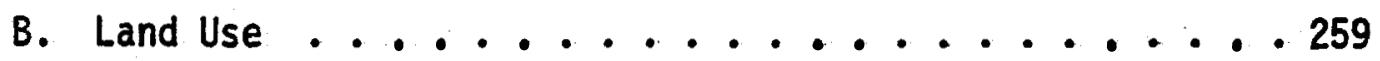

1. Introduction. . . . . . . . . . . 259

2. Population................... 260

3. Industrial Activity ............ 260

4. Agriculture ............... 265

5. Recreation ................. 269

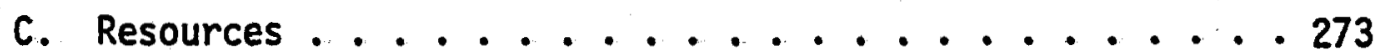

1. Renewable Resources . . . . . . . . . . 273

2. Nonrenewable Resources. . . . . . . . . 275

3. Cultural Resources ............. 277

4. Coastal Resource Management ......... 279

D. Natural Hazards ............... 285

1. Hurricanes and Accompanying Storm Surges. . ... . 286

2. Fresh Water Flooding. .......... 288

3. Tornadoes . . . . . . . . . . . . 290

4. Thunderstorms and Lightning ......... 291

5. Freezing Weather and Fog. . . . . . . . 292

IX. REFERENCES. .................... 293

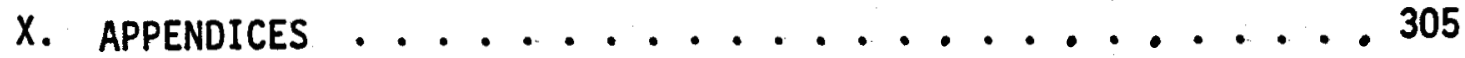

A. Description of Ecosystem Types in the Geopressured

Prospect Area, Louisiana ... . . . . . . . . 307

B. Summary of Consultations with Interested Groups . . . 319 


\section{FIGURES}

Page

Fig. I-1 Geopressured Study Area............. 11

Fig. III-A-1 Geopressured Prospect Areas. . . . . . . . . 50

Fig. III-B-I Activities Associated with Development of a Geopressured Reservoir ........... 54

Fig. III-B-2 Timing of Geopressured Development Activities. . . . 57

Fig. III-B-3 Flashed Steam Cycle. . . . . . . . . . 58

Fig. III-B-4 Binary Power Cycle ............. 59

Fig. IV-A-1 Profile Section Through the Gulf of Mexico Basin . . 78

Fig. IV-A-2 Thickness of Cenozoic Deposits in the Gulf Coast Geosyncline. .............. 80

Fig. IV-A-3 Geologic Dip Section Across South Texas Coastal Plain................ 83

Fig. IV-A-4 Preliminary Rates of Elevation Change. . . . . . 93

Fig. IV-C-1 Interaction of Efforts Related to Prediction of

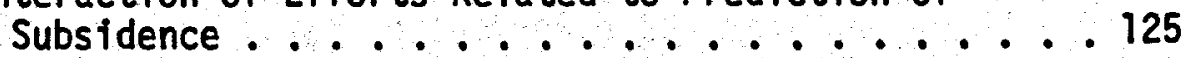

Fig. V-A-1 Frequency of Synoptic Weather Types and Associated

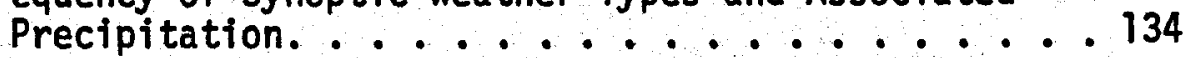

Fig. V-A-2 Louisiana Air Control Commission Monitoring Stations . 141

Fig. V-A-3 Locations of Special Air Quality Studies . . . . 147

Fig. V-C-1 Locations of Proposed Air Quality Monitoring

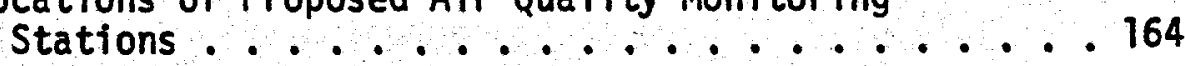

Fig. VI-A-I. Hydrologic Units of the Louisiana Coastal Marshes. . . 171

Fig. VI-A-2 Availability of Fresh Ground Water . . . . . . 175

Fig. VI-A-3 U.S. Geological Survey Water Quality Sampling Stations, Southeastern Louisiana . . . . ... 181

Fig. VI-A-4 U.S. Geological Survey Water Quality Sampling Stations, Southwestern Louisiana 
Fig. VI-A-5 Louisiana Stream Control Commission Water Quality Monitoring Stations.......... 183

Fig. VI-B-I U.S. Geological Survey Continuous Gaging Stations . . 194

Fig. VII-A-T Boundaries of Louisiana Coastal Zone. . . . . . 208

Fig. VII-A-2 Louisiana Coastal Marshes ............ 211

Fig. VII-A-3 Natural Vegetation Regions .......... 212

Fig. VII-A-4 Ridge Ecosystems ............... . . 213

Fig. VII-A-5 Relief Features and Regions . . . . . . . . 215

Fig. VII-A-6 Major Waterways, Pipelines, and 011 Fields Within Barataria Basin............ 225

Fig. VII-A-7 Typical Canal Networks, Louisiana Coastal Region. . 226

Fig. VIII-B-1 1970 Population Distribution, Urban and Rural . . . 261

Fig. VIII-B-2 Louisiana Parishes by Rate of Growth. . . . . . . 262

Fig. VIII-B-3 Projected Urban Growth Corridors. . . . . . . . 263

Fig. VIII-B-4 Mining as a Percent of Total Parish Employment. . . . 264

Fig. VIII-B-5 Payrolls in Petroleum and Chemicals . . . . . . 266

Fig. VIII-B-6 Parish Farm Income. . . . . . . . . . . 267

Fig. VIII-B-7 Modern Agricultural Regions . . . . . . . . 268

Fig. VIII-B-8 Louisiana State Recreation Land, South Louisiana. . . 270

Fig. VIII-B-9 U.S. Government Recreation Land, South Louisiana. . . 271

Fig. VIII-C-1 Main Commercial Species . . . . . . . . . 274

Fig. VIII-C-2 Mineral Production. ............ 276

Fig. VIII-C-3 Distribution of Archeological Sites, Coastal Louisiana .............. 280

Fig. VIII-D-I Flooding from Storm Surge During Hurricane Audrey .............. 2 287 


\section{TABLES}

Page

Table II-B-1 Dimensions of Geopresşured Operation. ....... 20

Table III-A-I Ranking of Geopressured Prospect Areas. . . . . 51

Table III-B-1 Well Field Parameters ............ 56

Table III-C-I Range of Concentrations Reported for Louisiana Geopressured Waters .......... 66

Table III-C-2 Summary of Water Analyses from the Edna Delcambre No. 1 Wel1.............. 68

Table III-C-3 Radioactivity Analysis of Delcambre Geopressured Fluid ................... 70

Table III-C-4 Gas Analysis from Delcambre Test Wel1 . . . . . 71

Table IV-C-1 Estimated Costs of Performing Geological Effects Studies ................ 127

Table V-A-1 Synoptic Weather Types .......... 135

Table V-A-2 Dispersion Characteristics of Synoptic Weather Types ................ 139

Table V-A-3 Ambient Air Quality Standards .......... 140

Table V-A-4 Ambient Air Quality Data, 1976, ContinuQus Monitoring Sites............, 143

Table V-A-5 Ambient Air Quality Data, 1976, Non-continuous. Monitoring Sites. ................. 144

Table V-A-6 Concentrations of Pollutants in South Louisiana . 149

Table V-B-1 Data Required for Assessment of Impacts on

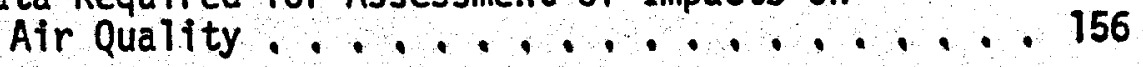

Table V-B-2 Meteorological Data Collected at National Weather Service Stations. ............ 160

Table VI-A-1 Louisiana Water Quality Criteria for Major Basins - 179

Table VI-A-2 Surface Water Quality Characteristics ... . . 184

Table VI-B-1 Data Requirements for Water Quality Impacts Assessment................. 192 
Table VI-C-1 Estimated Costs for Performing Surface Water Quality Studies.......... 199

Table VI-C-2 Estimated Costs for Performing Groundwater Quality Studies ........... 202

Table VII-A-1 Major Characteristics of Ecosystems . . . . . 216

Table VII-A-2 Threatened and Endangered Species . . . . . 218

Table VII-B-1 Data Requirements for the Assessment of Impacts on Ecosystems ............... 234

Table VII-C-1 Schedule for Performing Ecosystem Qualities Studies .............. . 244

Table VII-C-2 Estimated Costs of Ecosystem Quality Studies at an Offshore Site ........... 247

Table VII-C-3 Estimated Costs of Ecosystem Quality Studies at a Coastal Site........... 249

Table VII-C-4 Estimated Costs of Ecosystem Quality Studies at an Upland Site....................... 251

Table VIII-C-l Value of Louisiana Commercial Landings, Fish and Shellfish, 1975.............. 274

Table VIII-C-2 Parishes in the Geopressure Prospect Area by Rank of 1976 Severence Tax Collections. . . . 278 


\section{ABSTRACT}

E. J. Newchurch

This report presents the results of research by the Institute for Environmental Studies at Louisiana State University, to develop a plan for the long-term environmental assessment of geopressured/geothermal resource development in the Louisiana Gulf Coast region. This work was sponsored by the Lawrence Livermore Laboratory as part of a contract with the U.S. Department of Energy.

It has been assumed that full-scale development of the Louisiana geopressured resource wilt involve 50 or more sites, each $130-160 \mathrm{~km}^{2}$ (50-60 $\left.\mathrm{mi}^{2}\right)$ in area. For each site, we envision 15-20 producing wells, each producing some 40,000 barrels/day of fluid, 30-40 disposal wells, gas separation facilities, one 25 megawatt power plant, and about 200 miles of pipeline.

Whereas this study considered the effects of the development activities with the above listed facilities, it was beyond the scope of the study to consider the possible effects of ancillary development activities - that is industrial, commercial and residential activities resulting from non-electric uses of geopressured fluids. It is recommended that impacts stemming from such ancillary activities be carefully studied, and the results incorporated into the overall environmental assessment.

The major environmental issues stem from possible impacts which might result from: (1) subsidence associated with removing a large volume of fluids at high rates; and (2) disposal of equally large volumes of spent fluids by reinjection into shallow aquifers. Plans 
for the measurement and analysis of geologic effects include: (1) measurements related to subsidence, fault activation, and seismicity;

(2) sampling and testing to determine the mechanical properties of the geologic units involved as an aid in the interpretation of the effects measured in (1); and (3) computer modeling by the finite element method to provide a basis for predicting future geologic effects.

The south Louisiana coastal region is characterized by highly diverse and productive aquatic and wetland ecosystems. The economic value of these wetlands derives from their use as habitat by important commercial species of fish, waterfowl, and fur animals; and from mineral production. The value of the coastal wetlands in terms of recreational activities is also very high. Subsidence, should it occur, would have a significant adverse impact on this region. Much of the study area has very low elevations and relief, and is therefore vulnerable to extensive inundation from any measurable amount of subsidence. Marsh would be converted to open water, markedly reducing biological productivity, with the geopressured producer possibly facing private suits for damages or even injunctive relief. Plans have been developed for the assessment of impacts on ecosystem quality (1) offshore; (2) in the coastal region; and (3) in the upland and forest regions. Each plan involves the sampling of the biota, the water, and the substrate, with bioassays on selected organisms.

Regarding water quality, there is concern that the large volumes of water that must be disposed of, subsurface, may overtax the receiving aquifer with perhaps leakage of fluids up fault planes; or that abandoned oil and gas wells in the vicinity may be breached. Both ground 
water and surface waters could be adversely affected should this occur. Causes for concern include salinity, temperature, and total quantity of heat to be dissipated; as well as low dissolved oxygen content, and possible trace amounts of hydrogen sulfide, ammonia, copper, boron, and other toxic ions. Plans for assessing impacts on water quality include provisions for determining ground-water uses in the vicinity of a geopressured site, mapping ground-water resources, identifying sites of possible leakage, and sampling ground-water sources used for domestic and agricultural water supply. Surface water quality studies are to include monthly sampling and testing.

Air quality impacts are expected to be minor as compared to potential impacts on water and ecosystem quality. The major atmospheric emission from a geopressured power plant will be the steam plumes from wet cooling towers. Localized fogging will be possible. Fortunately, weather conditions in south Louisiana are generally favorable for the dispersion of atmospheric pollutants. If the Lake Charles, and Baton Rouge to New Orleans areas are avolded, it is likely that all state and federal air quality standards can be met. There will, of course, be some localized noise, but it should be possible to design around this potential problem. Plans for air quality assessment studies include the installation of three fixed location baseline air monitoring stations, equipped to obtain meteorological data. Additional fixed monitoring stations my be needed depending on the locations and configurations of the well sites once selected. Mobile testing will also be desireable to determine upwind and downwind concentrations of selected pollutants. 
The likely extent of the above described potential environmental impacts is unknown at the present time; thus, detailed studies should continue, beginning with reservoir testing activities. As more information becomes available, appropriate definitive plans must be incorporated into the overall design of the resource development so as to strike an acceptable balance between energy development and environmental quality.

A brief summary of the overall plan for the assessment of environmental impacts from geopressured resource development activities at a single prospect concludes this abstract.

\section{GEOLOGICAL EFFECTS}

OVERALL PRIORITY: HIGH

- Establish baseline conditions: subsidence history, surface elevations, seismicity.

- Monitor impacts: surface elevation changes, fault movement, seismicity.

- Determine compaction characteristics through laboratory materials testing and in situ rock mechanics tests.

- Model reservoir and overburden response to production.

- Analyze data and report results.

AIR QUALITY

OVERALL PRIORITY: LOW

- Establish regional baseline conditions.

- Establish site specific baseline conditions.

- Test and monitor emission streams.

- Monitor air quality.

- Perform dispersion modeling studies.

- Analyze data and report results. 
WATER QUALITY: SURFACE WATER

OVERALL PRIORITY: MEDIUM

- Establish baseline conditions: hydrology, water quality, usage.

- Test and monitor emission streams.

- Monitor surface water quality.

- Analyze data and report results.

WATER QUALITY: GROUND WATER

OVERALL PRIORITY: HIGH

- Establish baseline conditions: configuration, depth, groundwater quality, usage.

- Inventory existing wells.

- Monitor ground water quality.

- Analyze data and report results.

ECOSYSTEM QUALITY

OVERALL PRIORITY: MEDIUM TO HIGH

- Establish baseline conditions: substrate, biological surveys, bioassays.

- Monitor biological populations.

- Assess impacts.

- Conduct special studies.

- Analyze data and report results. 
U 
I. INTRODUCTION 



\section{INTRODUCTION \\ E. J. Newchurch}

This report presents the results of research, by the Institute for Environmental Studies, to develop a plan for the long-term environmental assessment of geopressured/geothermal resource development in the Louisiana Gulf coast region. This work was sponsored by the Lawrence Livermore Laboratory under Purchase Order No. 8316603, as part of its Contract No. W-7405-Eng. 48 with the U.S. Department of Energy (DOE).

The geopressured/geothermal resource of the Louisiana Gulf Coast region has the potential of becoming an important source of energy in the forms of natural gas, electricity and process heat. DOE-sponsored efforts are underway to assess the energy content of this resource, and eventually to test its deliverability with the goal of establishing commercial viability. In addition to environmental considerations, specific questions deal with number and locations of reservoirs, reservoir deliverability, natural gas content, disposal of spent fluids, economics, legal aspects, and institutional requirements.

Prior to commercial operations, it will be necessary to understand the potential environmental impacts so as to ensure that all activities involved in resource development take place in an environmentally sound manner. Accordingly, Lawrence Livermore Laboratory has authorized the study described herein to identify key environmental issues, to assess the adequacy of presently avallable environmental data, and to prepare a plan for: (1) acquiring additional baseline data; and (2) monitoring the environmental effects of geopressured resource development. This plan is designed to provide information necessary for informed decision-making 
concerning the long-term environmental assessment of geopressured resource development in Louisiana.

The study area covers that region of Louisiana which is bounded on the north by an east-west line drawn through Baton Rouge, and which extends south into the Gulf of Mexico (Figure $1-1$ ). This region includes the currently identified major propspect areas and is characterized by three major considerations:

- The geology varies significantly from east to west as a result of relatively recent geologic events, particularly changes in the course of the Mississippi River. This has resulted in deltaic formation and erosion in the central and eastern portions of the study area. The northwestern portion of the study area is of Pleistocene origin, while the southwestern portion is characterized by the chenier system.

- The land is flat with a very low elevation--the $5 \mathrm{ft}$ contour extending some 50 miles from the coast. Thus, there is a wide band of mixing between the surface waters of the wetlands and the Gulf of Mexico, resulting in very productive aquatic ecosystems. There is also much general flooding, and a potential for large impacts if subsidence occurs.

- The surface water varies from fresh to saline, with the salinity gradient generally running from north to south. The hydrology of this coastal region is much altered by resource development activities.

In this setting, we find a very complex mosaic of ecosystems, with large numbers of species of both plants and animals including many 


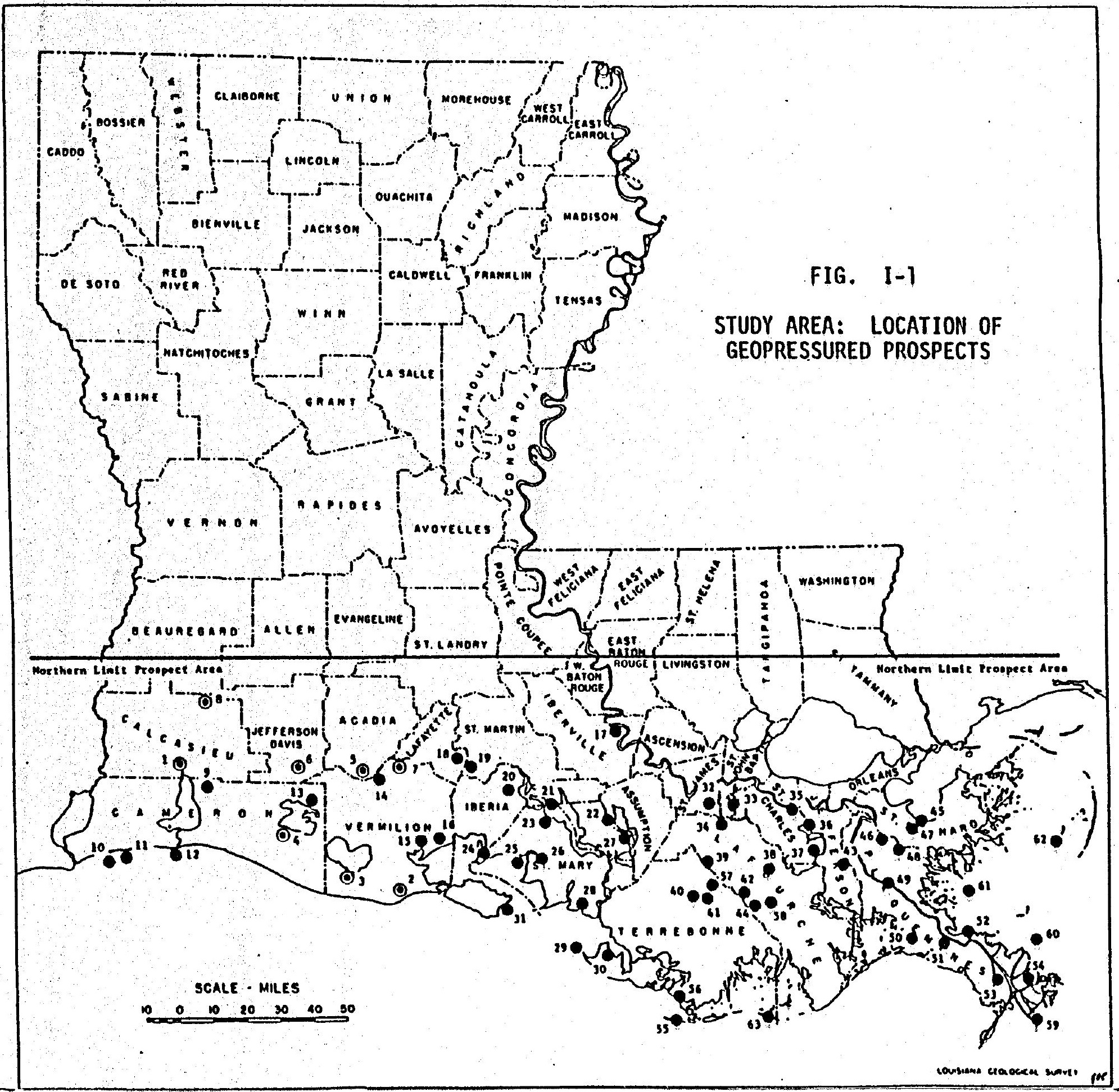


conmercially important species and several rare or endangered species. In addition, some parts of the study area are heavily populated and display a wide variety of cultural and economic activities.

The plan described in this report deals with the environmental aspects of geopressured resource development in the context of the above considerations, and is structured as follows:

- Integrated assessment

- Description of the proposed activity

- Geological effects

- Air quality

- Water quality

- Ecosystem quality

- Socioeconomic and cultural considerations

In the section, Integrated Assessment, an overall plan for the longterm environmental assessment of geopressured resource development activities is presented. The plan is drawn from the work described in the subsequent sections. Key environmental issues are also identified and reviewed in the Integrated Assessment, as well as the approach taken in identifying these issues and the criteria for assigning priorities. The section includes a discussion of those factors considered to be beyond the scope of this project. Finally, three natural regions within the study area are identified as to their relative vulnerability to development activities.

The section, Description of the Proposed Activity, is presented as a prelude to the subsequent sections dealing with environmental quality. This section describes the resource and the energy extraction operations; both 
developed in sufficient detail to provide a basis for identifying the potential sources of impacts on the various sub-systems of the environment.

The section on geological effects describes the geological framework of the study area and discusses the potential effects on this geology stemming from the development of the geopressured/geothermal resource. A plan is presented to measure, interpret and predict geological effects. This discussion lays the groundwork for a consideration of three separate areas of potential impact--air, water, and ecosystems. In each of these sections, the environmental setting is described, potential impacts are identified, and plans are proposed for baseline and monitoring studies. All of the plans are preceeded by a discussion of the data required to establish baseline conditions as well as for monitoring potential impacts. The adequacy of these data is also considered.

The finat section, Socioeconomic and Cultural Considerations, discusses the land uses, resources, and natural hazards of the study area, and relates these considerations to the development of the geopressured/geothermal resource. 
$\mathcal{U}$

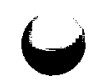




\section{INTEGRATED ASSESSMENT}
A. Introduction
B. Dimensions of the Operation
C. Key Environmental Issues
D. Other Considerations
E. Overall Plan 
0

0 


\section{INTEGRATED ASSESSMENT \\ E. J. Newchurch and A. L. Bachman}

A. INTRODUCTION

The purpose of this section is to present an overali view of the environmental issues facing decision-makers in the area of geopressured resource development in Louisiana, along with a plan for monitoring potential environmental impacts. The material presented here draws from the separate assessments and plans for geological effects, air and water quality, and ecosystem quality described in detail in Sections IV through VII; and from the discussion of socioeconomic and cultural considerations in Section VIII.

In each of these sections, the relative significance of potential impacts is discussed. We have combined these assessments to arrive at the overall priorites of the issues. This priority 1ist, the approach and criteria used to develop it, and a discussion of the issues are presented in Section II-C, following. To place the issues in the appropriate technological context, Section II-B gives a brief summary of a development scenario that will be typical of full-scale resource development activities in Louisiana.

The research problem addressed in this report is a difficult one to treat comprehensively, given the size and variation in the study area, and time and funding constraints. The LSU investigators circumscribed the problem in several specific ways, as set forth in Section II-D. These include 1 imitations on the kinds of impacts examined, and assumptions concerning existing geologic data. The size and variability of the study area also calls for a summary of which natural regions could be most 
severely impacted by resource development activities. This subject is addressed in Section II-C, as well.

The overall plan for assessing potential environmental impacts is given in Section II-E. The plan is essentially an overview of the individual plans presented in the main body of the Report, except that the overall plan is not specific as to natural region or ecosystem type. It is, however, directly keyed to the nature of the Louisiana resource and the characteristics of the Louisiana natural environment. The overall plan, as well as the individual plans, emphasizes baseline data collection and impact monitoring and prediction for the full-scale development case. 


\section{B. DIMENSIONS OF THE OPERATION}

The dimensions of a model geopressured operation are summarized in Table II-B-I for the full-scale development of a prospect area 50-60 square miles in extent. It is envisioned that such a fully developed geopressured field will have 15-20 producing wells, each producing approximately $40,000 \mathrm{bbl} /$ day of fluid.

In this scenario, it is assumed that the spent fluids will be pumped back into the ground, into a different formation, but safely below the base of frest ground-water. The fluids will flow in the producing wells under their own pressure, but it will be necessary to pump them against the resistance of the receiving formation for disposal; therefore, it is assumed that there will be a need for two disposal wells for each producing well. Well spacing, for producing wells, is assumed to be one per 3-4 square mile area. Disposal wells will be interspersed among the producing wells.

The fully developed well field will support a power plant of approximately 25 megawatts capacity, located in the well field. Approximateiy 200 miles of pipel ine will be required to transport the fluids from the producing wells to the power plant and back to the disposal wells. Energy output from the reservoir will include electricity, methane stripped from the geopressured water, and residual heat in the spent fluids which can be used in nearby indastries for process heat.

It will, of course, be recognized that the density of wells in this operation is small as compared to a typical oil and gas field with one well for each 40 acres. On the other hand, the rate of fluid removal in a geopressured well is projected to be perhaps 100 times as great as in 


\section{TABLE II -B - I}

\section{DIMENSIONS OF GEOPRESSURED OPERATION (FULL SCALE DEVELOPMENT)}

Prospect Area $=50-60$ sq. mi.

Producing Wells $=15-20$

Flow Rate $\quad=40,000 \mathrm{bbl} /$ day $/$ well

Disposal Wells $=30-40$

Power Plant $=25$ megawatts

Pipelines $\quad=200$ miles 
the case of a typical oil well. It's this large volume of fluids that provides for a large part of the environmental concern.

The type of activities which will be involved in the development of the geopressured resource, all of which are potential sources of environmental impact, fall under the broad headings of site preparation and. construction, operations, accidental occurrences, and natural hazards.

During site preparation and construction, it will be necessary to build roads and levees, structures of various types, pipelines, and canals to provide access in wetland sites. Operations will include drilling of wells, operation of the successful producing wells, drilling and operation of two reinjection wells for each producing well, and operation of the pipelines. All of these types of operations, of course, are similar to those encountered in oil and gas production. But now we add an energy plant, pipelines, and transmission lines to deliver the net energy recovered to consumers--perhaps some distance away. These represent additional potential sources of impact in a fragile environment.

As in the case of 011 and gas operations, there will be some risk of accidental occurrences such as well blowouts and well casing failures, which would result in fluid spills. A1so, in the Gulf coast there is always the risk of natural hazards such as hurricanes, and storm related flooding, causing accidents and possibly adding to the environmental risk of the overa 11 operation.

A number of possible non-electric uses of geopressured fluids are being explored, ranging from process and space heating to the recovery of minerals present in the fluids. Non-electric customers will have to be located close to the well field in order to minimize heat loss and 
fluid delivery costs. Thus, if non-electric uses prove feasible, considerable ancillary development activities could take place including industrial, commercial and residential development. The impacts from these ancillary activities have not been considered in this report solely because of time and funding constraints. 


\section{KEY ENVIRONMENTAL ISSUES}

The prime approach taken in identifying those environmental issues that could impede development of the geopressured resource in Louisiana involved consultations with industry and regulatory agency representatives. These meetings were conducted as interviews and in workshop settings. In each case, the LSU researchers presented a scenario for the full-scale development of geopressured resources, as summarized in the preceding: section, and then asked for input on the major environmental concerns. The approach was very successful. The industry and regulatory agency representatives were chosen on the basis of a strong interest in development of the resource and/or direct involvement in environmental regulation of development activities. A complete summary of these contacts is given in Appendix $B$ of this report.

Representatives of research groups with expertise in the environmental setting of the geopressured prospect region were also interviewed. These contacts were particularly helpful in placing future geopressured activities within the context of present and projected land use in the area. Conflicts among goals for use of the coastal wetlands, upland regions, and offshore portions of the study area were identified and this information considered in assigning priorities to potential enviromental impacts. A list of research groups and individuals consulted is. given in Appendix B.

From these contacts, criteria for prioritizing environmental issues were established. These criteria are as follows:

- Probability of Occurrence: Is there a high degree of probability that impacts will result from this issue?

- Magnitude: Will this issue result in impacts both large in areal extent and highly destructive to the environment? 
- Existing Impacts: Does this issue involve an impact that is already affecting the region and is expected to affect the region in the future?

- Management: Is this issue or the impacts resulting from this issue subject to management, mitigation, or control?

- Alternatives: Can this issue be resolved by employing alternative technologies or by engaging in alternative activities?

- Legal Setting: Is this issue subject to legal means of control? Could legal redress halt or delay development?

- Uncertainty: Is there a high degree of uncertainty concerning this issue and the impacts that arise from it? Does this uncertainty constitute a risk for the developer?

1. High Priority Issues

\section{a. Subsidence}

The most critical issue affecting the development of geopressured resources in Louisiana is possible surface subsidence due to compaction of sediments at depth as large quantities of fluid are produced. The effects of even a small amount of subsidence in the large portion of the study area that is at low elevation and low relief could be highly destructive. These effects would include inundation of large areas; increased areas prone to flooding; reduced biological productivity in the inundated areas causing economic losses in fish and shellfish harvests; loss of important water-fowl and fur animal habitat; and damage to roads and structures. It is likely that surface subsidence, if it occurs, would extend beyond the boundaries of the producing geopressured reservoir. 
There is considerable uncertainty as to whether subsidence will occur and how much will occur in the full-scalle development case. There are no analogous situations. Subsidence from ground-water withdrawal is well documented, but such subsidence has occurred as a result of compaction at depths considerably shallower than those that will be encountered in geopressured operations. Surface subsidence, if it occurs, is likely to lag behind peak production, thus compounding the uncertainties that otherwise exist. Subsidence from natural compaction of sediments in the Gulf of Mexico region is an ongoing process resulting in loss of coastal marshes, and this impact is already of concern. Subsidence from geopressured operations would add to the existing problem, and it may be difficult to discern the subsidence effects from the separate causes.

The State of Louisiana is sufficiently concerned about the potential for subsidence to provide for monitoring activities in the regulations for geopressured operations. Whether or not the State is satisfied on this issue, it is thought that private land owners adjacent to the leased acreage could file suit against the operator for damages or injunctive relief because of subsidence effects. (Lessors would be presumed to have agreed to the effects of subsidence which would be considered a normal result of operation of the lease).

Management of subsidence effects or management to reduce the probability of occurrence is a subject that has received little study. One alternative that has been suggested--reinjecting the spent fluid into the producing formation--appears not to be economically feasible.

The issues are: Will subsidence occur? How much will occur? What will be the areal extent of subsidence effects? Can subsidence be predicted? Can compaction at depth be prevented? Can subsidence effects be mitigated? 


\section{b. Fluid Disposal}

Large quantities of spent geopressured fluids, as much as 800,000 barrels/day in the full-scale operation of a single geopressured prospect area, must be disposed of in a manner compatible with environmental quality. Surface disposal will be possible only into the open Gulf, and this alternative seems unlikely because of the likely presence of toxic substances in the geopressured fluids. Subsurface disposal is thus the most likely disposal method; in many areas it will be the only feasible a) ternative.

Subsurface disposal of wastes in the total quantity, and at the rate anticipated in the full-scale development of a geopressured prospect, has never been attempted in Louisiana. Geologists generally agree that large volumes of suitable receiving sands exist in the disposal zone (at depths of $\sim 1500$ meters). This thesis is not proven for the circumstances of geopressured development, however. Industry representatives have expressed considerable concern about disposal because of the great risk involved in the failure of a disposal system where no alternative methods exist.

Possible environmental impacts of the failure of a subsurface disposal system include fouling of fresh-water aquifers; contamination of hydrocarbon producing areas; bleeding of fluids to the surface alona fault planes with possible severe surface effects; and breaching of abandoned wells with possible severe surface effects: These impacts could result because of intercommunication between the disposal aquifer and other aquifers and fault planes; overpressuring the disposal aquifers; and improperly abandoned wells in the area. 
South Louisiana is already faced with the problem of salt water encroachment of fresh-water aquifers pumped for rice irrigation and other domestic and agricultural uses. Failure of a subsurface geopressured disposal system would add to these problems.

Difficulties have arisen in the sub-surface disposal of brines in the Strategic Petroleum Reserve Program in Louisiana. These problems include plugging of disposal wells, and other technological fallures. U.S. Department of Energy representatives have expressed concern over the environmental impacts of further failures. The State of Louisiana has evidenced its concern over this issue through extensive regulation of drilling practices in geopressured operations to prevent contamination of fresh-water aquifers and hydrocarbon zones, and to minimize the likeIthood of leakages.

Subsurface disposal system failures can be minimized by assuring that suitable disposal aquifers are used; by employing an adequate casing program in disposal wells; by careful operation of the disposal wells and extensive monitoring of the disposal system; and by replugging improperly abandoned wells.

The latter two courses of action will be very costly and difficult to achieve. First, it will be difficult to monitor the fate of spent fluids disposed of at depth. "Fingerprinting" the geopressured fluids definitively may not be possible because contamination will occur as a result of brines migrating from depths of approximately 1500 meeters (500 ft) through non-homogeneous formations. Determining the direction of groundwater flow in an area of special concern may require a costly network of observation wells. Second, the areas of interest for geopressured re- 
sources have been extensively explored for oil and gas. Wells drilled before 1920 did not come under casing or abandonment regulations. These wells, and some more recent wells, are difficult or impossible to locate because of 1 and use changes and surface disruption. The other management methods can be achieved successfully; although, at the present time, the most critical factor--availability of suitable disposal aquifers--is not known.

The issues are: Do suitable disposal aquifers exist? Is the technology available adequate for disposal of fluids in the volumes envisioned here? Are monitoring and management methods adequate?

c. Surface Disruption in Wetland Areas due to Site Preparation and Construction Activities

The scenario for full-scale development of a geopressured prospect specifies a total of 20 producing and 40 disposal wells, $320 \mathrm{~km}$ (200 miles) of pipelines, and a 20-30 megawatt capacity energy plant with gas separators. This level of activity in a $130-160 \mathrm{~km}^{2}\left(50-60 \mathrm{mi}^{2}\right)$ area will cause a considerable amount of surface disruption. This is particularly true in wetland areas where access canals, pipeline canals, and impoundments will be required. The cumulative effects of widespread geopressured resource development (there are 63 identified prospects in south Louisiana) would indeed be serious.

The environmental impacts of this kind of surface disruption in wetland areas include: land loss and attendent habitat loss; disruption of normal hydrology resulting in salt water intrusion in coastal wetlands with subsequent habitat loss for important commercial species; 
possible warming of waters locally; and loss of archeological sites of which there are over 400 in the coastal region. (In upland portions of the study area, impacts would be much less severe. Some land use. changes would result; the most likely being some loss of crop and pasture Tand.)

The impacts from geopressured site preparation and construction activities are of particular concern should they take place in the coastal wetlands. This region is both unusually sensitive to these kinds of activities and unusually valuable in terms of commercial productivity, recreation, and cultural and scientific interest. Most of the identified geopressured prospects are within this area. There is already a problem in coastal wetlands with land loss due to natural subsidence and erosion: and as a result of canal dredging, channelization and other human activities. The total amount and rate of land loss is large and the effects are serious in the area, as the coastal marshes perform several vital functions. The coastal wetlands act as habitat for comercially important fish and shellfish, fur-bearers and waterfowl, as buffer of storm surges; and as a natural filtration system for pollutants originating in the more populated upland regions.

There are no state regülations concerning this issue at the present time. However, if the State of Louisiana develops a coastal resource management plan (planning grants made available under the 1972 coastal Zone Management Act have been used to develop a data base for a plan which is before the State legislature at this time), some state effort to reconcile land and resource uses in the coastal region will result. This could have an impact on geopressured resource development. The 
U.S. Army Corps of Engineers is responsible for issuing permits for the disposal of dredge and fill material in the coastal wetlands. This regulatory function allows an avenue for private groups to attempt to block certain kinds of activity: an avenue that is being used more frequently in Louisiana.

The surface effects of site preparation and construction activities can be mitigated to a certain degree. Directional drilling might be employed; helicopters can be used to emplace certain kinds of equipment; canals can be properiy oriented and maintained to minimize land loss and impacts on the hydrologic system. In order for management methods to be effective, however, information on the biota of each geopressured site, and on the hydrology of the site, must be obtained. Currently available data are not adequate for such an assessment. Hydrologic data in the coastal region are sparse.

The issues are: What is the extent of impacts on wetland ecosystems? A satisfactory answer to this question hinges on a thorough understanding of the biology and hydrology of the area and on monitoring capabilities.

\section{Medium Priority Issues}

a. Accidental Spil1s

In many types of activities, accidental spills of produced or waste fluids would be considered a low priority issue because of the low probability of occurrence, and because of effective prevention technology and clean up procedures. Accidental spills are a medium priority issue in the geopressured case, however. First, the impact in terms of air, water and ecosystem quality would be severe in the immediate vicinity, 
depending partly on the biotic communities present, meteorological conditions, hydrologic patterns, and soils properties. Certainly, the nature of geopressured fluids is such that any plant species, at least, to come in contact with spilled fluids would not survive. Volumes and rate of flow of spilled fluids is likely to be high. Second, clean up methods commonly used in the oil and gas industry may not prove as effective in the event of a geopressure well blowout. The emissions in the geopressure case would include brines and methane gas, and these are not as readily susceptible to containment as are the more viscous and flammable liquids of oll well blowouts. Also, because bottomhole pressures will be high--in excess of 10,000 psi, well blowouts in the geopressure case may be more difficult to bring under control.

Blowout prevention technology is advanced as regards the conventional oil and gas industry. It is uncertain whether there are differences between the effectiveness of blowout preventors on wells producing geopressured fluids as opposed to 011 and gas wells; or whether geopressured wells would be more likely to blow out than oil and gas wells. Certainly the oil and gas industry is experienced in drilling through geopressured zones; producing geopressured fluids may be another matter. In any event, should a blowout occur, the impacts would generally be more severe in the geopressured case. A thorough understanding of the impacts in different environments is required to assess the risks of accidental spills.

The issues are: What are the impacts of accidental spills? What containment methods are effective? Is prevention technology adequate? 


\section{Low Priority Issues.}

a. Air Quality and Noise Impacts from Normal Operations

Atmospheric emissions from the normal operation of producing and dispoal wells, gas separators, and the power plant, in the full-scale development situation are not expected to contribute significantly to air quality degredation. The major and most visible emission will be the steam plumes from wet cooling towers which could cause localized fogging under unfavorable meteorological conditions. Atmospheric dispersion characteristics in the study area are generally favorable, however. Also, the relatively small size of the power plant will tend to 1 imit adverse effects to a relatively small area.

The study area is a non-attainment region for ozone; however, geopressured operations are not expected to contribute to this problem.

Atmospheric hydrogen sulfịde emissions are of major concern in many of the world's geothermal resource areas, but pollutant gas concentrations of $\mathrm{H}_{2} \mathrm{~S}$ are not expected in the Louisiana geopressured fluids. However, because $\mathrm{H}_{2} \mathrm{~S}$ concentrations could vary from well to well, the presence of $\mathrm{H}_{2} \mathrm{~S}$ must be considered an unknown at this time. If appreciable $\mathrm{H}_{2} \mathrm{~S}$ levels are found, control technology is commercially available and, it is assumed, would be employed.

High localized noise levels can be expected during normal operations. Noise abatement equipment is available to ameliorate this problem, however.

\section{b. Induced Seismicity and Fault Activation}

Seismicity and fault activation as a result of producing or injecting geothermal fluids are major concerns in geothermal areas in western states. The Gulf Coast region, however, is generally lacking in the generation of seismic activity. Evidence from drilling seismic exploration for oil 
and gas have documented the slow and continuous release of stress along the many growth faults in the region. Only two seismic events have been reported in Louisiana in this century. If stress were to accumulate along fault zones as a result of reduction in pore pressure in geopressured reservoirs, release could result in many small "earthquakes" or microseisms. These would likely be too weak to be felt by humans, or to cause damage due to earth shock.

It is remotely possible that accumulated stress would be released in a more drastic fashion. Fault movement should therefore be monitored during geopressured fluid production. Ground-based instruments are avaitable for this purpose.

\section{c. Natural Hazards}

Tropical storms and hurricanes with gale force winds and storm surges occur frequently in the Gulf coast region compared to other parts of the country. They represent a significant threat to human life and property in the area. However, hurricane monitoring usually allows sufficient time for evacuation of personnel, and the shutdown of vulnerable drilling operations. Hurricane damage rarely results in well blowouts or other accidental spills. 


\section{OTHER CONSIDERATIONS}

The area of interest for geopressured resource development, depicted in Figure $1-1$, includes all of south Louisiana. This large region varies considerably in both natural setting and in human use of these environments. Given time and funding constraints, this fact imposed certain limitations on the range of impacts considered. Possible environmental impacts of ancillary development activities were judged beyond the scope of this work. These include the potential impacts of industrial, residential and commercial activity generated efther by extraction activities or because of non-electric utilization of the hot fluids. These kinds of activities could impact both the natural and socioeconomic environments. Also, the effect of normal operations and accidental occurrences on the health of workers was considered beyond the scope of this profect. A plan for assessing impacts on the socioeconomic and cultural environments was not developed because of the major contribution health considerations and ancillary development activities would. make to such an assessment.

In order to develop comprehensive plans in the time allotted for the project, the LSU investigators limited the scope of the work in several additional areas. The major assumption was made that suitable aquifers for the subsurface disposal of spent geopressured fluids are available. Neither the individual plans for geological effects and water. quality studies described in sections IV and VI, respectively, nor the overall plan sumarized below include activities designed to locate such aquifers. These activities are fundamental to the success of geopressured operations, as discussed in the preceding section. Also, the effectiveness of various impact abatement and management technologies 
and practices were not explored in depth. The overall plan and individual plans do not include activities that will resolve questions on this subject. There is a need for these kinds of activities, particularly in conjunction with subsidence studies.

Finally, the plans were developed for prototype geopressured prospects or reservoirs, and not for geopressured prospects in specific geographic settings. There:are 63 identified geopressured prospect areas. Of these, fewer than 10 have been studied in depth geologically. Authors of this report felt that a more efficient approach was to develop plans based on average Eouisiana reservoir characteristics, and to specify, when necessary, differences in implementing the plans in three basic natural settings. These three areas are upland, coastal, and offshore regions.

Coastal regions are the most vulnerable to the impacts discussed in the previous section. The coastal wetlands are uniquely productive biologically, providing habitat for many commercially important species. The key to both the biological diversity and productivity of Louisiana wetlands is the unbroken intercomunication among many ecosystem types and the predictable cycles of physical events. Subsidence and surface disruption from site preparation and construction activities could seriously disturb these balances. Although sparsely populated, there is already competition among land uses in the coastal areas resulting in significant deterioration and destruction of the marsh ecosystems.

Upland regions would be less vulnerable than coastal areas to impacts from subsidence and construction activities. The higher elevations of the upland region will help contain subsidence effects if they occur, al though damage to structures and roads is a possibility 
in these areas. The upland areas would be more vulnerable to failures in subsurface disposal systems, which would be the only feasible disposal alternative. The principal land use in the upland portions of the study area is agriculture; specifically rice in the western and central parts of the study area. Rice is an irrigated crop, using fresh ground water resources extensively.

Offshore geopressured resource development would conflict least with the goal of maintaining environmental quality. Subsidence would have no adverse effects if confined to the offshore areas. Accidental spills would disperse more quickly than in coastal and upland environments. Also, surface disposal might be a feasible al ternative, if federal and state water quality standards can be met.

The plans for water and ecosystem quality described in Sections VI and VII take into account these differences among ecosystem types. The overall plan summarized in Section II-D below, is not specific as to the natural setting. 


\section{E. OVERALL PLAN FOR THE LONG TERM ENVIRONMENTAL ASSESSMENT OF GEOPRESSURED RESOURCE DEVELOPMENT IN THE LOUISIANA GULF COAST REGION}

The Plan outlined below is for collecting baseline data, and monitoring the impacts, from full-scale geopressured resource development at a single geopressure prospect area. The Plan is not specific to a particular prospect for environmental setting, but is generally applicable in the study area.

Monitoring efforts will continue at a reduced level for the entire period of production: approximately 20 years. The level of effort in monitoring activities will be contingent on the occurrence of impacts from development activities or other environmental changes. Some monitoring activities are contingent on data availability or the development of adequate instrumentation.

\section{GEOLOGICAL EFFECTS}

Issues Addressed: Presence, extent, and causes of surface subsidence, fault activation, and seismicity. Prediction of surface subsidence.

Priority: Surface subsidence--high; fault activation--low; seismicity--low.

I. Pre-Development Activities.

A. Leve1 1: Detection Activities--Baseline Data Collection.

- Establish leveling network and perform initial leveling survey.

- Install seismic monitoring system.

- Establish subsidence history from aerial photos and other data.

- Analyze results to estabilish baseline conditions. 
B. Level II: Materials Testing.

- Perform near-surface soils test and analyze results for correction of tiltmeter readings.

C. Level III: Prediction.

- Develop preliminary model to simulate reservoir and overburden response to production.

II. Post-Development Activities.

A. Level 1: Detection Activities and Preliminary Interpretation.

- Extend leveling network to cover all well clusters and perform annual releveling.

- Install integrated tiltmeter system and monitor continuously.

- Monitor seismic system.

- Perform annual aerial photographic surveys to measure subsidence effects (i.e. inundation) if necessary.

- Log representative wells and prepare geologic cross sections.

- Record production and reservoir data.

- Analyze data to determine extent of geological effects and preliminary causal interpretation of field data.

- Report results to appropriate agencies and impacts assessment groups.

B. Level II: Materials Testing.

- Core representative wells and perform laboratory tests on cores.

- Perform in situ rock mechanics studies if adequate instrumentation is available.

- Analyze data to determine compaction characteristics and to measure extent of compaction at depth.

C. Level III: Prediction.

- Revise model with relevant data from Level I and Level II activities until agreement with field conditions exist.

- Analyze data to develop predictive capability.

- Report results to appropriate agencies and other impacts assessment groups. 


\section{AIR QUALITY}

Issues Addressed: Extent, cause, and prediction of atmospheric emissions and dispersion.

Priority: Emissions during normal operations--low; accidental emissions--medium.

I. Pre-Development Activities.

A. Regional Activities.

- Install fixed location monitoring stations.

- Monitor ambient air quality conditions, including background activity of $\mathrm{H}_{2} \mathrm{~S}, \mathrm{NH}_{3}$ and others.

- Collect meteorological data for atmospheric dispersion characteristics.

- Perform dispersion modeling studies.

- Identify existing emission sources.

- Analyze data to establish regional baseline conditions.

- Determine level of compliance with federal and state standards.

B. Site Specific Activities.

- Install fixed location monitoring station.

- Monitor ambient air quality conditions, including background activity of $\mathrm{H}_{2} \mathrm{~S}, \mathrm{NH}_{3}$ and others.

- Collect meteorological data for atmospheric dispersion characteristics.

- Perform dispersion modeling studies.

- Identify existing emission sources.

- Analyze data to establish site specific baseline conditions.

- Determine level of compliance with federal and state standards. 
II. Post=Development Activities.

A. Emissions.

- Perform laboratory tests on emission streams: heat, $\mathrm{H}_{2} \mathrm{~S}, \mathrm{NH}_{3}$, methane, and others.

- Monitor emission streams: cooling tower exhaust, main condenser purge, and others.

B. Air Quality.

- Monitor ambient air quality conditions from fixed location station.

- Conduct mobile testing.

- Perform dispersion modeling studies.

- Analyze data to determine and predict conditions under normal operations and in event of accidental emissions.

- Determine level of compliance with federal and state standards.

- Report results to appropriate agencies and other impacts assessment groups.

WATER QUALITY: SURFACE WATER

Issues Addressed: Extent and cause of water quality impacts.

Priority: Impacts from disposal--high; impacts from site preparation and construction activities--medium; impacts from accidental spills--medium.

I. Predevelopment Activities.

A. Hydrologic Studies.

- Inventory surface water bodies.

- Determine drainage, discharge, mixing characteristics.

- Determine recent history of hydrologic changes.

- Analyze data to establish baseline hydrologic conditions.

B. Water Quality Studies.

- Conduct sampling program: physical and chemical parameters.

- Monitor water quality conditions. 
- Inventory surface water usage.

- Identify pollution sources.

- Analyze data to establish baseline water quality conditions.

- Determine level of compliance with federal, state, and local standards.

- Report results to appropriate agencies and other impacts assessment groups.

II. Post-Development Activities.

A. Emisstons.

- Perform laboratory tests on fluid emission streams: TDS, boron, radon, and others.

- Monitor fluid emission streams: spent brine, separator condensate, condenser condensate, and others.

B. Hydrologic Studies.

- Monitor hydrologic conditions.

- Analyze data to determine extent and cause of hydrologic changes.

- Report results to appropriate agencies and other impacts assessment groups.

C. Water Quality Studies.

- Monitor water quality conditions.

- Perform dispersion studies.

- Analyze data to determine extent and cause of water water quality impacts.

- Determine level of compliance with federal, state, and local standards.

- Report results to appropriate agencies and other impacts assessment groups.

WATER QUALITY: GROUND WATER

Issues Addressed: Extent and cause of ground-water impacts.

Priority: Impacts from disposal--high; Impacts from accidental occurrences--medium. 
I. Pre-Development Activities.

A. Ground-water Resources.

- Determine ground-water usage.

- Determine and map configuration and depth of groundwater aquifers from existing data and well logs.

B. Ground-water Quality.

- Conduct sampling program: specific conductance, temperature, dissoived solids, and others.'

- Monitor ground-water quality conditions.

- Identify pollution sources and pollution history.

- Analyze data to establish baseline ground-water quality conditions.

- Report results to appropriate agencies and other impacts assessment groups.

C. Abandoned Wells.

- Inventory abandoned oil, gas and water wells.

- Field inspection of abandoned wells.

- Review abandonment records.

- Make recommendations to appropriate groups on replugging improperly abandoned wells.

II. Post-Development Activities.

- Review data on fluid emission streams.

- Collect and review data on production and disposal.

- Conduct shallow induction logging program on all wells.

- Revise maps of ground water resources.

- Conduct sampling program and monitor ground water quality.

- Monitor conditions at abandoned well sites.

- Drill observation wells and monitor for hydraulic and water quality changes, if necessary.

- Analyze data to determine extent and causes of impacts on ground-water quality and impacts from subsurface fluid disposal system failure. 
- Report results to operator, appropriate agencies, and other impacts assessment groups.

ECOSYSTEM QUALITY

Issues Addressed: Extent and cause of impacts on ecosystem quality.

Priority: Impacts from subsidence--high; impacts from fluid disposal--high; Impacts from site preparation and construction activities--medium; impacts from accidental occurrences--medium; impacts from normal atmospheric emissions--low.

I. Pre-Development Activities.

A. Biological Survey.

- Identify control area.

- Perform biological surveys in control and developed areas.

- Compile biological inventories.

- Map vegetation.

B. Other Studies.

- Obtain data and results of pre-development studies of water quality.

- Determine substrate composition.

- Determine life histories of selected speciés.

- Conduct acute and chronic bioassays on selected organisms.

- Analyze data to establish baseline conditions.

- Report resuits to appropriate agencies and other impacts assessment groups.

II. Post-Development Activities.

A. Biological Surveys.

- Monitor biological populations.

- Assess impacts on biological populations from normal operations and accidental occurrences. 
B. Other Studies.

- Collect data and results from other impacts assessment groups.

- Perform periodic bioassays on selected organisms.

- Monitor substrate composition.

- Conduct special studies, if necessary.

- Analyze results to determine the extent and cause of impacts.

- Determine level of compliance with federal, state and local regulations.

- Report results to appropriate agencies and other impacts assessment groups.

OVERALL RECOMMENDATIONS

The LSU investigators recommend that this plan be implemented, with appropriate modifications, for the first fully-developed geopressured prospect in each of the following natural settings:

- Offshore areas.

- Coastal areas.

- Upland areas.

The results from each of these areas will indicate the level of effort required in development of additional prospects. Portions of the plan may be applicable to less than full-scale development situations. 
III. DESCRIPTION OF THE PROPOSED ACTIVITY

A. Introduction

B. Technological Scenario

C. Resource Characterization 


\section{DESCRIPTION OF THE PROPOSED ACTIVITY \\ D. P. Harrison}

\section{A. INTRODUCTION}

Geopressured/geothermal (hereafter referred to as geopressured) systems are known to exist throughout the entire Gulf Coast regions of Louisiana and Texas. As shown in Figure III-A-1, identified Louisiana prospect areas extend completely across the state in the east-west direction, and approximately as far north as a line drawn through Baton Rouge (latitude $30^{\circ} 30^{\prime}$ ). Although not shown on the map, the resource is also known to extend into the Gulf of Mexico for distances as great as $160 \mathrm{~km}$ (100 miles) (Hawkins, 1977).

Recent resource assessments indicate that the most favorable prospects are located in the southwestern and south-central portion of the state: specifically in Cameron, Vermilion, Iberia, St. Mary and Terrebonne Parishes and adjacent waters; and in the inland parishes: Calcasieu, St. Martin, and Assumption. Table III-A-I gives the locations and pertinent data for a preliminary ranking of the 20 most promising prospect areas (Bernard, 1977). However, because prospect areas exist throughout the region in the southern third of the state, the entire area south of the line drawn through Baton Rouge in Figure III-A-I is defined as the study area in this report.

Geopressured systems are unique in that recoverable energy may be obtained from as many as three sources. Reservoir pressures in excess of $7 \times 10^{7} \mathrm{~Pa}(10,000 \mathrm{psi})$ may be tapped by means of hydraul ic turbines to produce electricity or other forms of useful energy. The high temperatures within the reservoir, believed to be in the range of $90-200^{\circ} \mathrm{C}\left(200-400^{\circ} \mathrm{F}\right)$, may be used for a number of purposes ranging from electrical power generation 


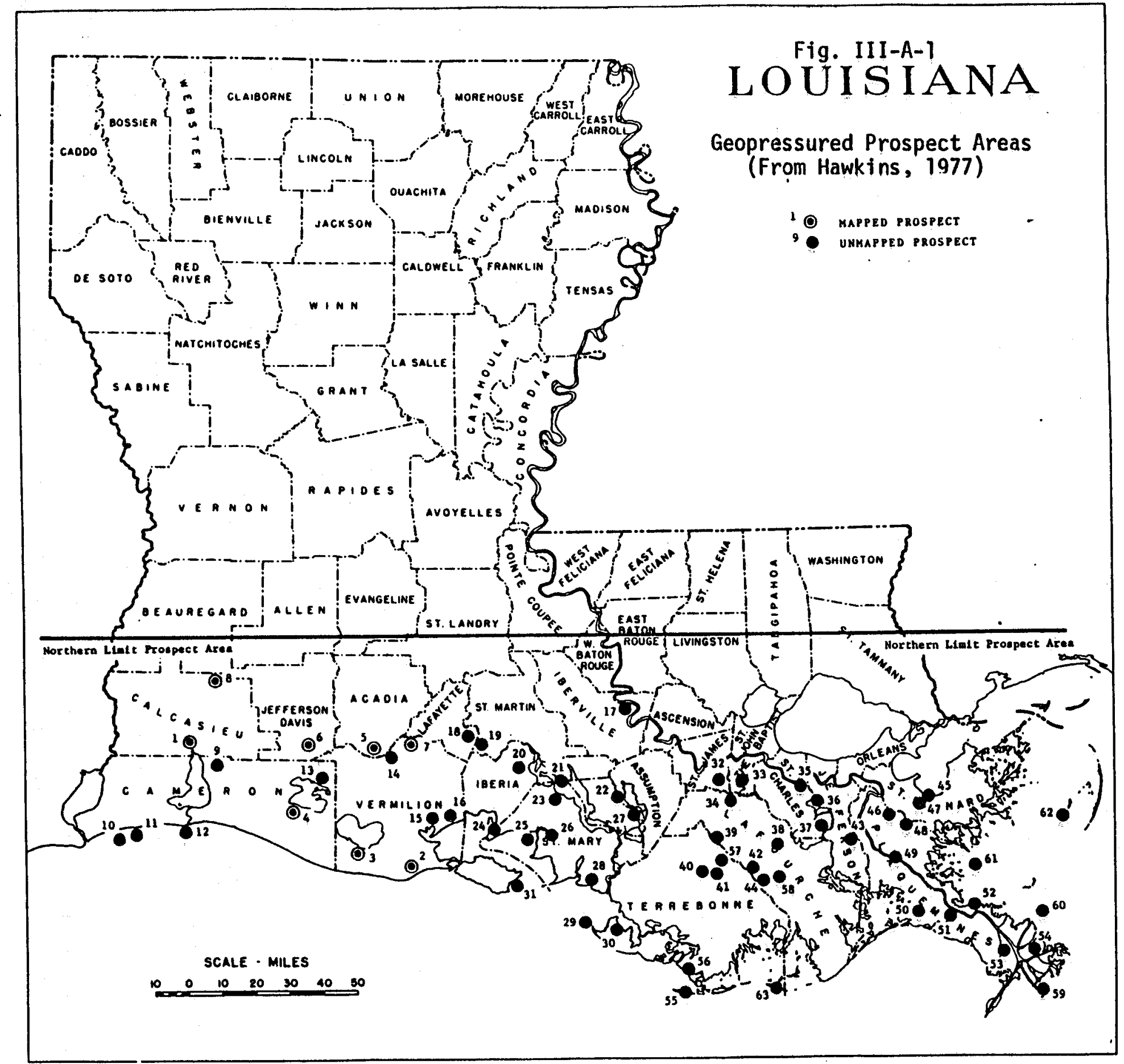


Table III-A-1. Preliminary ranking of geopressured prospect areas in Louisiana: first 20 ranked prospect areas. (From Bernard, 1977)

Avg. Temp. No. Geop.

Overall Prospect

Area Percent Avg. Mud

Gradient Wells in Geop. Wells/

Ranking Number

Parish Twp. Rge. Sg. Miles Sand Weight pa

${ }_{\mathrm{F} / 1000} \mathrm{ft}$ Prospect

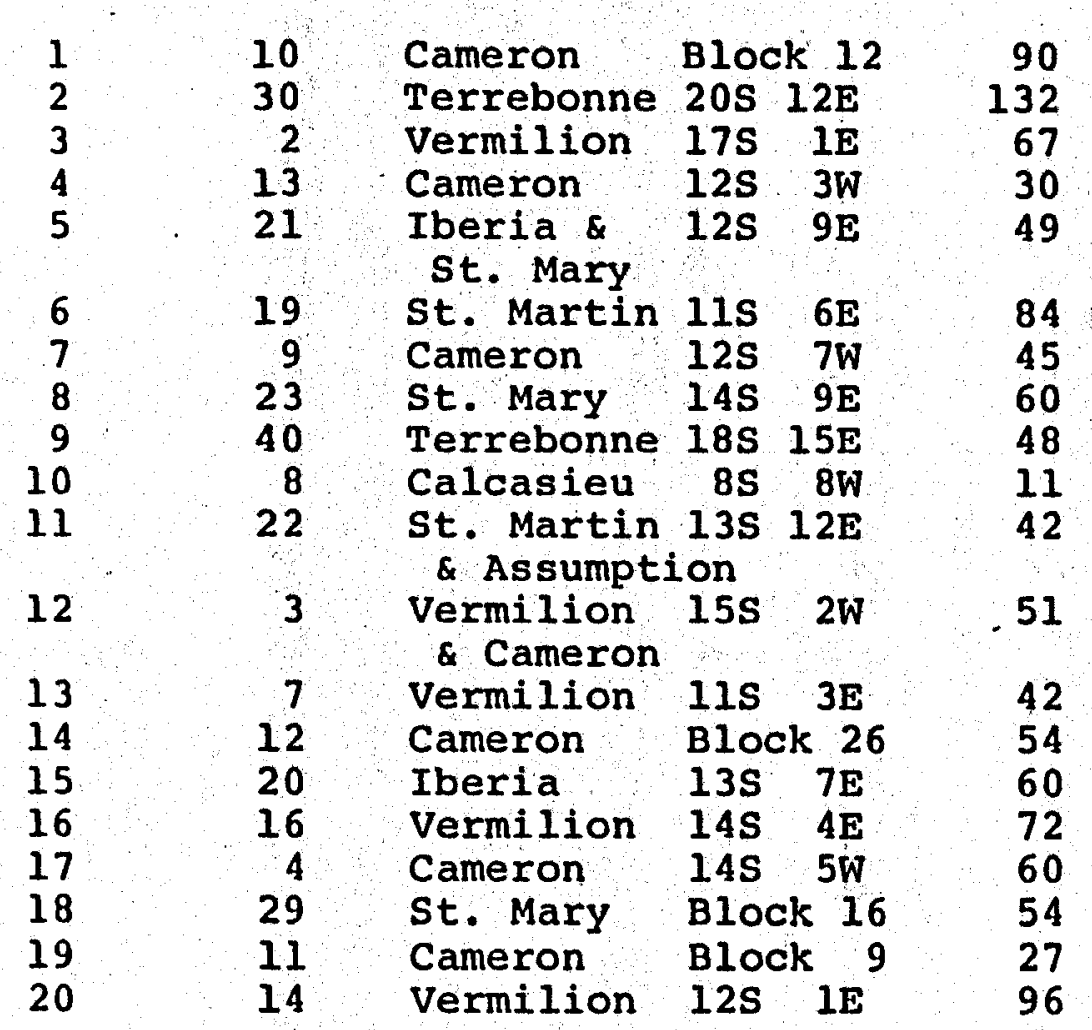

20.3
34.6
11.8
8.4
24.5
23.3
14.9
18.8
17.5
16.9
21.2
13.2
7.3
20.8
21.8
15.2
9.8
19.9
18.4
9.2

15,0
14.4
16.2
15.8
14.5
14.9
15.7
15.2
15.8
15.1
15.4
15.9
16.8
16.3
13.9
15.0
16.1
15.0
14,6
15.5

11.30

10.53

12.20

12.47

11.57

20

27

12

15

11

All Wells

10.13

11.95

11.12

10,73

11.79

10.48

20

35

11

10

8
18

1.000

1.000

1.000

1.000

1.000

13.00

4

1,000

0.972

1.000

1.000

1.000

0.947

11.43

12.23

10.29

10.65

12.37

10.91

11.62

11.26

1.000

1. 000

0.900

1.000

1.000

0.694

1.000

0.938

0.955

9 
to space heating. Finally, there are strong indications that large volumes of natural gas may be recovered from geopressured waters and used to supplement the nation's dwindling natural gas supply. At this stage in the development of the resource, estimates of the total energy in Louisiana range from a high of just over $1 \times 10^{21}$ joules ( 965 quads) to a low of approximately $3 \times 10^{19}$ joules (34 quads) (Papadopulos, et. al., 1975, high estimate; Hawkins, 1977, low estimate). Regardless of the uncertainty, the overall potential is sufficiently attractive to warrant major funding from the U. S. Department of Energy to prove the resource potential.

Activities in the overall development will range from short term testing under the DOE "wells of opportunity" program, to possible eventual commercialization of a geopressure field with natural gas recovery, electric power generation and perhaps process uses of the hot waters. Each of these activities will have its own unique set of environmental impacts. Full discussion of the impacts of each level of activity is clearly beyond the scope of this study; hence, this analysis concentrates on those environmental impacts expected from the full-scale cominercialization of the resource. This approach should include all potential impacts, although the relative importance of each may shift at different stages in the course of development. For example, the most significant impacts when the activity is limited to drilling and short term testing of a single well will be different from those expected from full-scale resource development.

Considerable interest has been expressed by industry in recovering only the natural gas from geopressured reservoirs (e.g., Wilson; Rust, personal communication, 1977). However, to meet the objectives of this study, the activities described below involve producing the total energy content of the geopressured fluids. 


\section{B. TECHNOLOGICAL SCENARIO}

\section{General}

The activities discussed in this section comprise the technological scenario on which the identification of environmental impacts is based. This scenario and the alternatives specified represent the most likely course of development. The scenario is based on published reports (Wilson, et a1., 1977; Zinn, et. a1., 1978), and on discussions with industry and regulatory agency representatives (Christopher, Rust, Wilson, Durham, Chauviere, LaFleur, personal communication, 1977).

All potential activities of a totally developed geopressured reservoir are shown schematically in Figure III-B-1. Fluid from a number of producing wells will be piped to a central processing site. At this site natural gas (methane) will be recovered, compressed, and shipped to consumers via pipeline. Electricity will be generated using the hydraulic and/or thermal energy of the fluid. Geopressured fluid exiting the power generation step will be in the temperature range of $60-90^{\circ} \mathrm{C}\left(140-200^{\circ} \mathrm{F}\right)$, have a high salinity, and possibly contain components which are toxic to plant or animal life. The remaining thermal energy may be further utilized for such applications as space or process heating or as a chemical feedstock for the recovery of valuable components. Following this potential secondary use, proper disposal of the "cool" fluid must be accomplished. In the absence of secondary utilization, the fluid leaving the power generation plant must be directly disposed of. Under either option, it is assumed, for the purposes of this study, that it will be the responsibility of the primary resource developer to see that proper disposal procedures are followed. Each of these activites is described in greater detail in the following sections. 


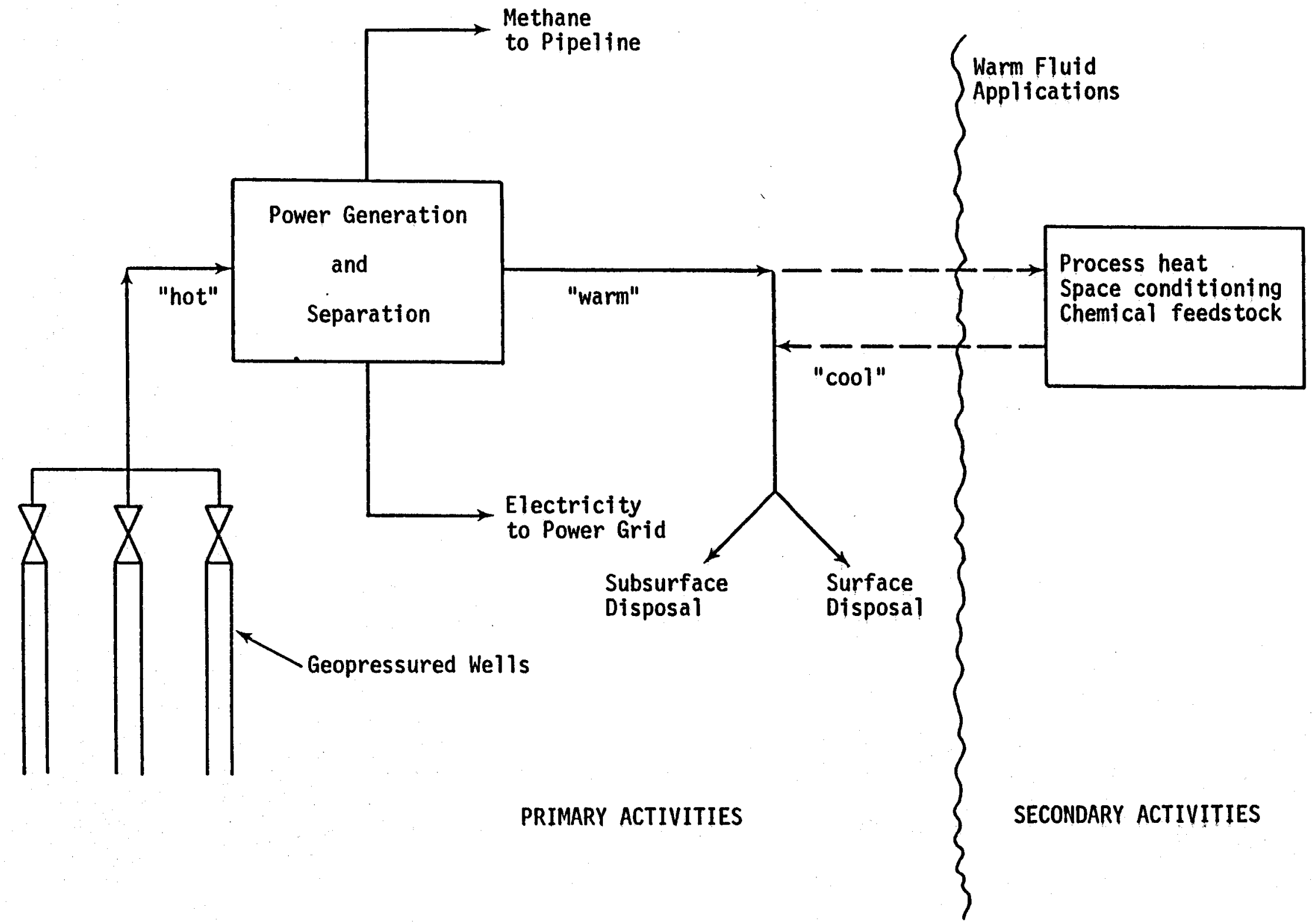

Fig. III-B-1. Schematic diagram of activities associated with total development of a geopressured reservoir. 


\section{Weil Field Development}

A Louisiana geopressured reservoir, assessed as having good resource recovery potential, is expected to support approximately 20 geopressured wells, each producing at a rate of $6.4 \times 10^{3} \mathrm{~m}^{3}(40,000$ barrels) per day. These wells will support a power generation facility with a 20-30 MW generating capacity. If the spent fluid is disposed of via subsurface injection, an additional 40 disposal wells will be required. Production wells will be spaced at one per approximately $8-10 \mathrm{~km}^{2}$ (one per 3-4 $\mathrm{mi}^{2}$ ) area with disposal wells interspersed between producing wells. The areal extent of the prospect is expected to be approximately $130-160 \mathrm{~km}^{2}\left(50-60 \mathrm{mi}^{2}\right)$. The geopressured field will be crossed by some $320 \mathrm{~km}$ (200 miles) of producing and disposal pipelines. Table III-B-1 sumarizes well field parameters and pertinent assumptions.

Drilling and completion of a producing well is expected to require approximately four months with $11 / 2$ months required for each disposal well. Plant construction is expected to take some 3 to 4 years. An overall activity time line for the project is shown in Figure III-B-2. This well field development scenario is specific to the Louisiana geopressured reservoirs as described by Hawkins (1977), and was developed in consultation with Bernard and Waguespack (personal communication, 1977) and from Zinn, et. a1. (1978).

\section{Energy Recovery}

Two processes, shown schematically in Figures III-B-3 and III-B-4, have been proposed for the full-scale utilization of the geopressured resource. Each recovers the methane present in the geopressured fluid and utilizes both the hydraulic and thermal energy of the resource. 
Table III-B-1. Well field parameters and assumptions for a Louisiana geopressured prospect with favorable reservoir characteristics.

Rate of flow, producing wells

No. of production wells drilled

Success ratio

No. of producing wells

Ratio, disposal to producing wells

No. of disposal wells

Well spacing, producing wells

Well spacing, disposal wells

Areal extent of prospect

No. of energy plants supported

Power plant capacity

Extent of pipeline required for collection, disposal
$6.4 \times 10^{3} \mathrm{~m}^{3}(40,000$ barrels $)$ per day per well

20-27 wells

.75

15-20 we $71 \mathrm{~s}$

2

30-40 wells

1 per 8-10 $\mathrm{km}^{2}\left(3-4 \mathrm{mi}^{2}\right)$ area

interspersed among producing wells

$\sim 130-160 \mathrm{~km}^{2}\left(50-60 \mathrm{mi}^{2}\right)$

1

20-30 MW

ح $320 \mathrm{~km}$ (200 miles) 
Fig. III-B-2. Timing of geopressured well field development activities.

ACTIVITY TIME LINE (post-exploration)

\begin{tabular}{lllrrrr}
\hline & & Year & & & \\
& 0 & 1 & 2 & 3 & 4 & 5 \\
\hline
\end{tabular}

Activity

Well drilling

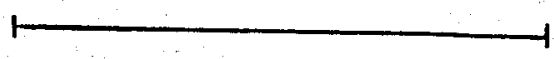

Energy plant construction

Energy production

$\vdash$ methane only $-+\frac{\text { methane, }}{\text { electricity }}$

ASSUMPTIONS

Drilling time required (assuming

4 months per producing well; 3

120-160 months months per dry well; 1.5 months

per disposal we11)

No. of rigs available

4

Months of drilling activity

30-40 months

Months of plant construction

42 months

activity

Economic life of plant

20 years 


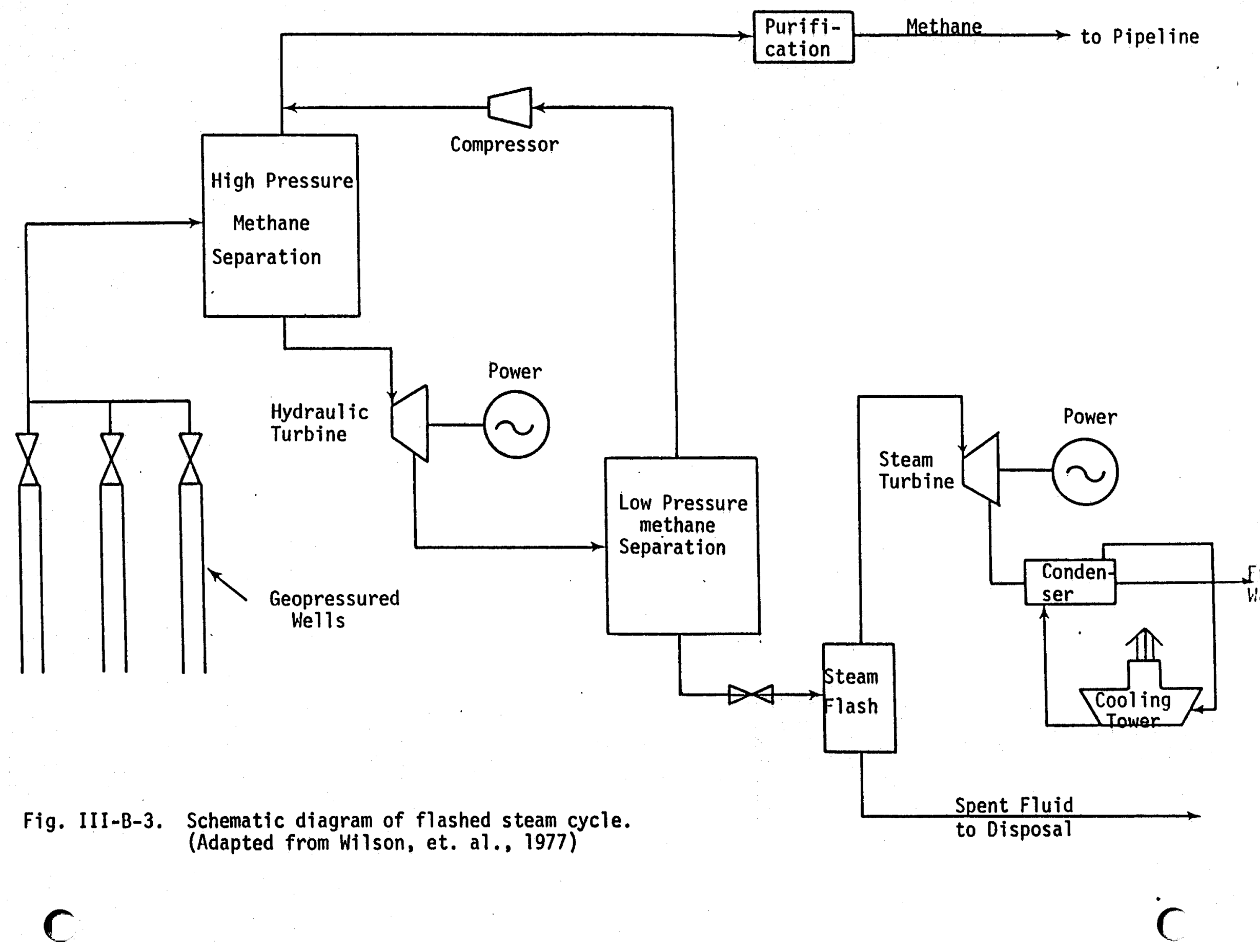




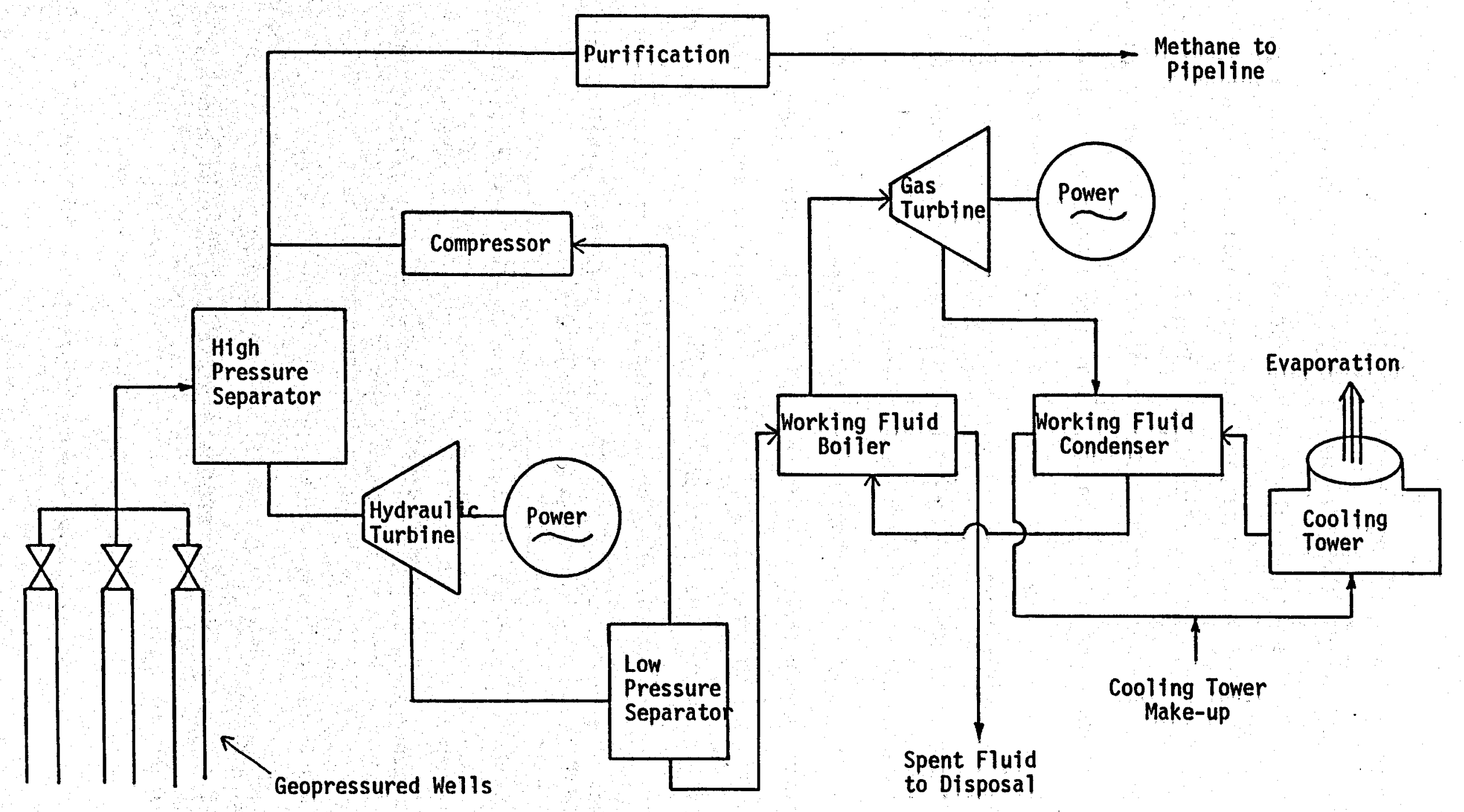

Fig. III-B-4. Schematic Diagram of binary power cycle. 
The flashed steam cycle shown in Figure III-B-3 has been described in several recent papers (e.g., Wilson, et al., 1977). Geopressured fluid from a number of wells will be collected for processing. Pressure reduction associated with flow from the reservoir to the well-head will cause much of the natural gas to come out of solution. This free gas will be recovered in the high pressure separator with the geopressured liquid directed through a hydraulic turbine connected to an electrical generator. The remaining natural gas may now be recovered and piped to the gas processing portion of the facility. Further pressure reduction causes a portion of the geopressured water to vaporize and the steam may be used to drive a low-pressure steam turbine connected to a second electrical generator.

The geopressured liquid emerging from the low pressure flash chamber may be either further utilized or disposed of directly. Steam turbine exhaust has lower concentrations of total dissolved solids than the liquid from the flash chamber. Depending upon the particutar case, the condensate may be utilized either separately or in conjunction with the bottom liquid, or disposed of either in conjunction with or separately from the bottom liquid.

The binary cycle, shown schematically in Figure III-B-4, is similar to the flashed steam cycle in its early stages. Natural gas separation is the first step, followed by electrical generation through a hydraulic tur-. bine. Thermal energy is recovered, however, by using the heat from the geopressured fluid to vaporize a suitable high pressure working field such as isobutane. The working fluid is used to generate electricity by passing it through an expansion turbine, a water or air-cooled condensor, and the vaporizing heat exchanger in a closed cycle operation. Brown and 
Root (1976) have provided a detailed analysis of this system.

The binary cycle system may be particularly appropriate for the Louisiana resource. While the general temperature range of Gulf Coast geopressured fluids is expected to be $90-200^{\circ} \mathrm{C}\left(200-400^{\circ} \mathrm{F}\right)$, the data currently available indicate that Louisiana's geopressured fluids are likely to be in the vicinity of $120^{\circ} \mathrm{C}\left(250^{\circ} \mathrm{F}\right)$. As the fluid temperature decreases, the amount of steam which may be obtained by flashing also decreases thus providing added incentive to substitute an appropriate secondary working fluid.

Because of the low fluid temperature, geopressure energy cycles have inherently low efficiency. For example, the flashed steam system considered by wilson (1977), produced an overall cycle efficiency (neglecting methane) of only $10.3 \%$ using as a design basis geopressured water available at the surface at $1.38 \times 10^{7} \mathrm{~Pa}(2000 \mathrm{psi})$ and $163^{\circ} \mathrm{C}\left(325^{\circ} \mathrm{F}\right)$. As a general rule, cycle efficiency will decrease with a decrease in both surface pressure and temperature. Lower cycle efficiencies would not change the kind of environmental impacts expected, but would tend to increase the magnitude of each of the separate impacts since greater production rates would be required to achieve a specified quantity of usable energy.

\section{Non-electric Uses of Geopressured Fluids}

The geopressured flufd exiting the power generation facility will be in the temperature range of $60-90^{\circ} \mathrm{C}\left(140-200^{\circ} \mathrm{F}\right)$. Numerous sugges tions have been made for the additional use of these spent brines for purposes ranging from process and space heating to the recovery of 
chemicals present in the water (e.g., Schnadelbach, 1977; Hornburg, 1975; Pile, et. al., in press). Schnadelbach (1977) has studied the south Louisiana food and related products industry to identify areas where hot brine might be effectively utilized and thereby replace natural gas and/or electricity. Pile, et. al., are examing agricultural uses of the waste heat from geopressured brines. A group at Johns Hopkins University is researching space conditioning applications of the spent brines. (Toth, personal communication, 1978). There is general agreement, however, that non-electric use of geopressured fluids will only develop as a by-product from the methane recovery/power generation industry. The costs of resource development could never be justified for process heat applications alone. In the development scenario presented here, we have charged the primary developer with the ultimate responsibility of satisfactory disposal of the brine. The potential environmental impact, therefore, will be little changed from the previous case of direct disposal following power generation.

\section{Fluid Disposal}

At the flow rate required to supply a 20-30 MW plant, a fullydeveloped geopressured field would produce as much as $12.8 \times 10^{4} \mathrm{~m}^{3}$ $(800,000$ barrels) of spent brine per day. Two disposal alternatives are anticipated: surface disposal into the Gulf, and subsurface disposal into relatively shallow aquifers below the base of fresh water. Water quality considerations prohibit the disposal of spent 
brines into fresh-water streams or coastal lagoons (LaFleur, personal communication, 1977).

A number of geopressured prospect areas in the coastal region of Louisiana ( and, of course, in the Gulf itself) are located near enough to open Gulf waters for surface disposal to be considered. Wilson, et. al. (1977) have suggested that the economic distance of the geopressured energy plant from the nearest body of saline water for surface disposal is less than $65 \mathrm{~km}$ ( 40 miles). At this distance (in rural areas) surface disposal would be less costly than subsurface reinjection. Of course, the presence of toxic components in the spent brines could eliminate surface disposal altogether.

If surface disposal were permitted, either an open-ditch system or pipeline would be used to transport the spent brines. Wilson, et. al. (1977) note the conditions that must be present for an open ditch system to be feasible: rural areas, few natural or constructed obstructions, gently sloping terrain, little or no topographic relief, little likelihood for run-off flood waters greater than approximately 0.66 meter ( 2 feet) deep.

Subsurface disposal of geopressured brines will be in aquifers below the base of fresh water. Approximately two disposal wells will be required for each producing well. The presence of suitable receiving aquifers underlying the well field is the principal constraint for this method of disposal. 
$\mathcal{U}$ 


\section{RESOURCE CHARACTERIZATION}

At this time, we must consider the physical characteristics of the geopressure reservoir--temperature, pressure, and fluid composition--to be largely unknown. Much of the available data was originally collected for other purposes and is, therefore, incomplete and subject to numerous questions regarding sampling and analysis techniques. Wilson, et al. (1977) have pointed out the questionable nature of the data in their tabulation.

As previously noted, the general temperature range of Gulf Coast. geopressured fluids is expected to be $90-200^{\circ} \mathrm{C}\left(200-400^{\circ} \mathrm{F}\right)$ (Wilson, et al., 1977). The average temperature for all prospects in Louisiana is $98^{\circ} \mathrm{C}$ $\left(209^{\circ} \mathrm{F}\right)--$ on the low end of this range. Maximum Louisiana geopressured fluid temperature is reported as $220^{\circ} \mathrm{C}\left(428^{\circ} \mathrm{F}\right.$ ) (Hawkins, 1977). Bottom hole pressures in excess of $7 \times 10^{7} \mathrm{~Pa}(10,000 \mathrm{psi})$ and well-head pressures under operating conditions of $1.4 \times 10^{7} \mathrm{~Pa}(2,000 \mathrm{ps} i)$ are expected (Hawkins, 1977; Bernard, personal communication, 1977).

Table III-C-I summarizes the range of fluid composition values from the individual tabulations of Wilson. Thus, we could encounter water ranging from near potable quality to brines approximately ten time more saline than sea water.

One should not assume that the absence of any component from the Table III-C-I list implies the absence of that component from geopressured fluids. The correct conclusion is that the component was simply not analyzed for. Further, one should not assume that the analyses of Table: III-C-I will be representative of reservoirs selected for geopressured development. These samples originated from oil and gas development where avoidance of geopressured formations is normally desired. 
Table III-C-1. Range of concentrations reported for Louisiana geopressured waters. (From Wilson, et a1., 1977).

\begin{tabular}{|c|c|c|c|}
\hline Component & $\begin{array}{l}\text { Concent } \\
\text { Minimum }\end{array}$ & $\frac{\text { on, mg/T }}{\text { Maximum }}$ & $\begin{array}{l}\text { Number of } \\
\text { Analyses Reported }\end{array}$ \\
\hline $\begin{array}{l}\text { Total Dissolved Solids } \\
\text { Sodium } \\
\text { Potassium } \\
\text { Calcium } \\
\text { Magnesium } \\
\text { Chloride } \\
\text { Sulfate } \\
\text { Bicarbonate } \\
\text { Lithium } \\
\text { Strontium } \\
\text { Barium } \\
\text { Bromine } \\
\text { Iodine } \\
\text { Boron }\end{array}$ & $\begin{array}{r}200 \\
10 \\
50 \\
8 \\
0 \\
10 \\
0 \\
0 \\
2 \\
3 \\
4 \\
14 \\
5 \\
18\end{array}$ & $\begin{array}{r}345,000 \\
103,000 \\
1,100 \\
33,000 \\
24,000 \\
201,000 \\
407 \\
2,500 \\
18 \\
265 \\
1,000 \\
213 \\
74 \\
67\end{array}$ & $\begin{array}{l}64 \\
65 \\
45 \\
65 \\
63 \\
66 \\
61 \\
65 \\
46 \\
10 \\
34 \\
44 \\
45 \\
38\end{array}$ \\
\hline
\end{tabular}


In May, June and July 1977, the abandoned Edna Delcambre \#1 gas well, near Delcambre, Louisiana, was reopened expressly for the purpose of geopressured fluid testing. Two geopressure sands: sand \#3 at approximately $3.93 \times 10^{3} \mathrm{~m}(12,900 \mathrm{ft})$; and sand \#1 at approximately $3.84 \times 10^{3} \mathrm{~m}(12,600$ ft) were perforated and produced. These tests marked the first instance in which geopressured fluids in south Louisiana were deliberately produced. Rather complete liquid and gas analyses were obtained. These results provide perhaps the best data currently available on the composition of Louisiana geopressured fluids. However, they should not be assumed to be representative of a 11 Louisiana geopressured fluids for several reasons. First, they represent data from a single site, and we can expect fluid composition to vary significantly from site to site. The tests were of short duration and, therefore, do not necessarily represent steady state conditions. Finally, the original well was drilled because of its natural gas potential; the site most probably would not have been selected solely for development of geopressured resources.

A summary of water analyses from the Edna Delcambre well appears in Table III-C-2. The data was presented by Hankins at the Third GeopressuredGeothermal Energy Conference in November 1977 (Hankins, et al., 1978).

The overall agreement between the data in Tables III-C-I and III-C-2 is good. Each of the entries of Table III-C-2 lies within the range established in Table III-C-I with the exception of strontium where the measured values from the Delcambre well exceed the previously reported maximum values. The concentration of boron lies near the previously reported maximum values.

Hankins, et a1., (1978) note certain trends in their data. For example, the concentration of iron decreases with increasing flow rate. They attribute at least a portion of the iron content to contact with 
Table III-C-2. Summary of water analyses from the Edna Delcambre No. 1 well. (From Hankins, et a1., 1978).

\begin{tabular}{lrr}
\hline Component & \multicolumn{1}{c}{ Sand \#3 } & Sand \#1 \\
\hline Total Dissolved Solids & 175,000 & 133,000 \\
Total Hardness $\left(\mathrm{as} \mathrm{CaCO}_{3}\right)$ & 6,100 & 6,800 \\
Chloride & 67,000 & 80,000 \\
Silicate (as $\left.\mathrm{SiO}_{2}\right)$ & 58 & 57 \\
Bicarbonate $\left(\mathrm{as} \mathrm{CaCO}_{3}\right)$ & 1,100 & 1,100 \\
Calcium & 1,700 & 2,100 \\
Magnesium & 160 & 180 \\
Iron & 7 & 11 \\
Zinc & 290 & 1 \\
Strontium & 290 & 400 \\
Boron & 60 & 63 \\
Sodium & 43,000 & 46,000 \\
Potassium & 290 & 290 \\
pH & 6.2 & 6.1 \\
\hline
\end{tabular}


the processing equipment. Zinc values continually decrease with time, and this result is attributed to the zinc content of the pipe dope which is gradually flushed from the system.

Additional analyses are being conducted by laboratories across the country, but most of the results are not yet available. However, radioactivity data determined by the U. S. Geologic Survey Laboratory in Denver has been reported and is summarized in Table III-C-3. Certain of these values are reported to be a factor of ten higher than those observed in nearby surface waters. The potential radioactivity problem obviously requires additional attention.

Chemical analysis of the gases from the Delcambre production test was the subject of a paper by Karkalits and Hankins (1978) at the Third Geopressured-Geothermal Energy Conference. As far as can be determined, this is the only Gulf Coast geopressured gas analysis which has been reported. A summary of the results is shown in Table III-C-4. Clearly, methane is the major component of the gas. The heating value is reported to be near $3.4 \times 10^{7} \mathrm{~J} / \mathrm{std} \cdot \mathrm{m}^{3}$ (920 Btu/scf).

In general, hydrogen sulfide and, perhaps, ammonia are the primary pollutant gases associated wtih geothermal fluids. Hydrogen sulfide concentrations in excess of 15 mole per cent and ammonia concentrations approaching 2 mole per cent have been reported in some of the world's geothermal fluids (Kruger and 0tte, 1973). Pollutant gas concentrations of this level are not expected in the geopressured fluids. Wilson, et al. (1977) discount the importance of hydrogen sulfide almost completely, but Gustavson and Kreitler (1976; Gustavson, personal communication, 1977) note that it is not known if geopressured fluids will contain potential air pollutants. Neither hydrogen sulfide or ammonia were reported in 
Table III-C-3. Representative radioactivity analysis of Delcambre geopressured fluid. (From Karkalits and Hankins, 1978).

\begin{tabular}{|c|c|c|c|}
\hline Component & Sand \#3 & Sand \#1 & Units \\
\hline $\operatorname{Rn} \quad \begin{array}{l}\text { (gas) } \\
\text { (1iquid) }\end{array}$ & $\begin{array}{r}60 \\
400\end{array}$ & $\begin{array}{r}40 \\
200\end{array}$ & $\begin{array}{l}\mathrm{pCi} / \mathrm{T} \\
\mathrm{pCi} / 1\end{array}$ \\
\hline $137 \mathrm{C}$ & 1,500 & 1,000 & $\mathrm{pCi} / 1$ \\
\hline Gross $\alpha$ & 10,000 & 6,600 & as $\mu \mathrm{g} U / 1$ \\
\hline Gross B & 1,300 & 900 & as $\mathrm{pCi} / \mathrm{Sr} / 1$ \\
\hline${ }^{226} \sigma_{\mathrm{Ra}}$ & 350 & 240 & $\mathrm{pCi} / 1$ \\
\hline U & 0.12 & .05 & $\mu g / 1$ \\
\hline$K$ (dissolved) & - & 300 & $\mathrm{mg} / 1$ \\
\hline $40_{K}$ & - & 220 & $\mathrm{pCi} / 1$ \\
\hline
\end{tabular}


Table III-C-4. Typical gas analysis from Delcambre test well. (From Karkalits and Hankins, 1978).

\begin{tabular}{|c|c|c|}
\hline & \multicolumn{2}{|c|}{ Mole \% } \\
\hline Component & Sand \#3 & Sand \# 1 \\
\hline $\mathrm{CO}_{2}$ & 1.08 & 2.03 \\
\hline$N_{2}$ & 0.29 & 0.13 \\
\hline $\mathrm{CH}_{4}$ & 92.78 & 95.36 \\
\hline $\mathrm{C}_{2} \mathrm{H}_{6}$ & 3.47 & 1.73 \\
\hline $\mathrm{C}_{3} \mathrm{H}_{8}$ & 1.12 & 0.37 \\
\hline$i-\mathrm{C}_{4} \mathrm{H}_{10}$ & 0.42 & 0.09 \\
\hline $\mathrm{n}-\mathrm{C}_{4} \mathrm{H}_{10}$ & 0.32 & 0.09 \\
\hline$i-\mathrm{C}_{5} \mathrm{H}_{12}$ & 0.14 & 0.05 \\
\hline $\mathrm{n}^{\mathrm{C}} \mathrm{C}_{5} \mathrm{H}_{12}$ & 0.09 & 0.04 \\
\hline$C_{6}{ }^{\prime} s$ & 0.09 & 0.02 \\
\hline$c_{7}$ plus & 0.20 & 0.09 \\
\hline
\end{tabular}


72

the Delcambre data (Tables III -C-2, III-C-4). In supplementary discussions, Karkalits (personal communication, 1977) stated that sulfide concentrations in the water were less than $1 \mathrm{ppm}$, and that no hydrogen sulfide odor was detected in the gas samples.

However, because of its toxicity and low odor threshold, it is impertart that baseline environmental data acquisition plans be based upon a presumption of $\mathrm{H}_{2} \mathrm{~S}$ being present. The presence or absence of hydrogen sulfide in other situations seems to be quite unpredictable. Sweet natural gas fields lie near sour fields. In an Oklahoma project involving the production of geopressured fluid for iodine and methane recovery, it is reported (Reed, personal communication, 1977) that hydrogen sulfide levels from different wells in the same formation are quite variable. 
$112+1$

IV. GEOLOGICAL EFFECTS

A. Rationale

B. Data Requirements and Availability

C. Plan for the Acquisition of Data for the Assessment of Potential Geological Effects 
IV. GEOLOGICAL EFFECTS

R. Wilcox, J. A. Rehage, and K. J. Cunningham

The purpose of this section of the report is to provide a rationale for the assessment of geological effects from the development of the geopressured-geothermal resource based on the geological setting; and to present a plan for the assessment of potentially adverse effects to surface and subsurface geological regimes which could result from geopressured resource development in southern Louisiana.

\section{A. Rationale}

\section{Introduction}

The potential effects on the environment of geopressured resource development are both varied and complex in relationship to the geological setting in southern Louisiana. Ground-surface subsidence, earthquakes, and extensive ground-water pollution by toxic saline waste water are the most important environmental geological changes which may result from production and disposal of geopressured water. (Water quality aspects of subsurface fluid disposal are discussed in Section VI). Because there has not been extensive production of geopressured waters from any Gulf Coast reservoirs in the quantities and at the rates anticipated, all estimates and projections of possible consequences of such production must be viewed with considerable caution.

Geological effects of geopressured resource development are of two types: (1) changes induced by the removal of large volumes of water and dissolved gases at high rates which alter the subsurface (reservoirs) pressure regime, and (2) effects related to disposal of the generally saline waste water in equally large volumes by reinjection into the subsurface or by surface dumping. The surface disposal alternative is generally agreed to be unilkely 
because of salinity and toxicity, unless the waters are suitably piped to and dispersed into the open Gulf of Mexico.

Removal of the geopressured water and consequent lowering of reservoir pressures may cause adverse effects on any production of oil and gas from nearby fields producing from the geopressured zone. Proposed state regulations on the production and disposal of geopressured waters are designed to protect oil and gas production from these effects (Harrel1, 1978). For this reason, the investigators making the resource assessment in Louisiana selected geopressured prospect areas which, if produced, would avoid any possible interference with established oil and gas production (Hawkins, 1977; Bernard, personal communication, 1977). Of greater general environmental concern is the potential for surface subsidence and induced seismicity (earthquakes), both of which are related to subsurface compaction and faulting in the vicinity of geopressured water production.

Subsurface disposal of the saline waste water should be accomplished without difficulty if sufficiently large masses of highly porous and permeable sands are present below the fresh-water (near-surface) zone and above the geopressured zone. There is some disagreement on this subject among geologists and industry and regulatory agency representatives. Determining the actual presence of suitable aquifers in the study area is beyond the scope of this study. However, the subject should be studied in depth given the large quantities of fluid that must be reinjected, and the likelihood that subsurface disposal will be the only alternative in most of the study area.

The following two sub-sections describe the geological setting of the geopressured-geothermal zones in the northern Gulf of Mexico basin and the potential environmental impacts of production from such zones. 


\section{Geological Setting: Northern Gulf of Mexico Basin}

a. General Geology

The following summary of the geology of the northern Gulf coast is based primarily on and in part quoted from the papers of Jones $(1975,1969 a$, 1969b). He has utilized many of the classic papers and books on Gulf Coast geology (e.g. Burst, 1969; Murray, 1961) and for many years has been a strong advocate of energy development from the geopressured formations of the Gulf Coast.

The Gulf of Mexico basin has been a prolific source of oil and gas from Mesozoic and Cenozoic deposits. These sediments overlie the southern continental margin of North America and, therefore, are underlain by Paleozoic rocks on the continental basin margins and by the oceanic floor of the Gulf in the basin center (Figure IV-A-1).

Wilhelm and Ewing (1972) have presented the geologic history of the Gulf of Mexico as interpreted from modern geophysical and drilling data. It is probable that the Gulf of Mexico formed and has been progressively enlarged as a result of slow horizontal displacements of crustal plates in the western hemisphere. The movement of crustal plates may have caused rifting in a continental crust followed by the rise of basaltic magma to form the present oceanic (simatic) crust in the central Gulf. Around the Gulf from north Florida, northwestward and westward via the ouachitaMarathon folded belt in Arkansas, Oklahoma, and Texas, and thence southwestward into Mexico, the Paleozolc basement was consolidated by the middle Pennsylvanian Ouachita orogeny. Postorogenic erosion and deposition during the latest Paleozoic, Triassic, and early Jurassic covered the simatic crust with a layer of continental (redbed) clastic sediments. During the 


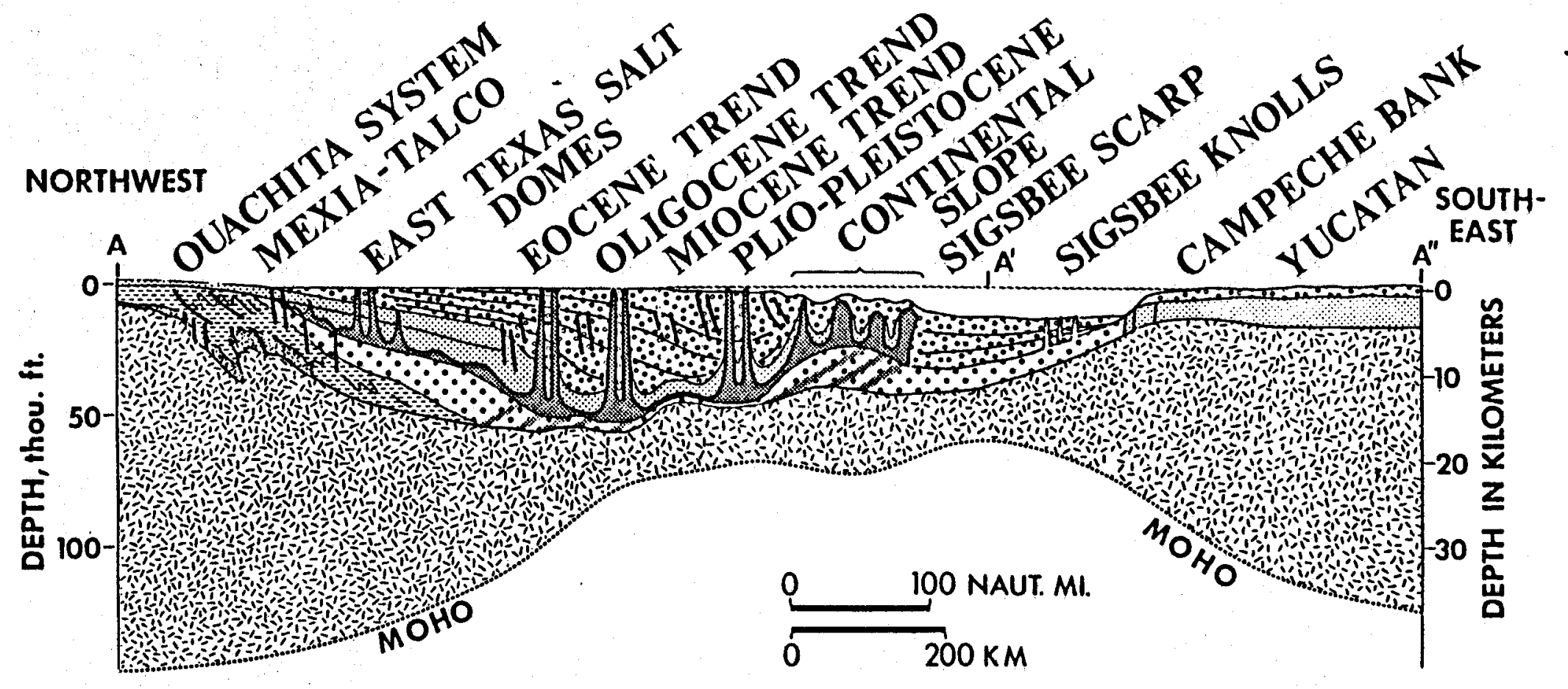

UPPER CRETACEOUS AND

TERTIARY CLASTIC FILL.

\% JURASSIC AND LOWER CRETACEOUS

SALT $\because \because$ LATE PENNSYLVANIANPERMIAN-TRIASSIC

OUACHITA FOREDEEP AND GEOSYNCLINAL FILL

WYY EARLY PALEOZOIC SHELF DEPOSITS

CRYSTALLINE BASEMENT

REFRACTION SPEEDS IN KM/sec.

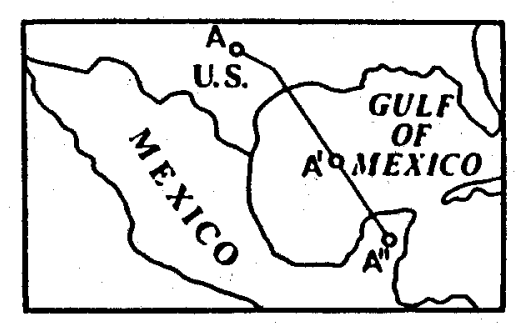

Fig. IV-A-1. Profile section through the Gulf of Mexico basin. (From Jones, 1975). 
late Jurassic, evaporites (salt and anhydrite) were deposited in the northern Gulf basins, which are now the Gulf Coast salt dome basins, and elsewhere along the southern basin margins. The florida and Yucatan carbonate platforms were constructed during the Cretaceous and early Tertiary times as the Gulf subsided and became a mediterranean deep-sea basin.

The final major episode in the development of the present: Gulf of Mexico began with the continent-wide Laramide orogeny during the late Cretaceous and Paleocene (earliest Tertiary). Huge quantities of Cenozoic clastic sediments derived from the continental interiors and deposited by the Mississippi River, the Rio Grande, and smaller rivers have blanketed all earlier deposits in the Gulf except the carbonate platform of Florida and Yucatan which continued to grow as the basin subsided. Along the northern Gulf margin (southern United States) this great thickness of sediment constitutes the Gulf coast geosyncline. It is this thick accumulation of sands and shales, locally faulted and intruded by salt domes, which contains the geopressured formations.

The Cenozoic sediments are primarily clay and sand; the clay fraction is dominated by montmorillinite with lesser amounts of lllite, kaolinite and chlorite; the sand is mainly quartz. These Cenozolc deposits completely fill the Gulf Coast geosyncline, along the northwest margin of the Gulf basin, and have a volume exceeding 1 million cubic miles. The aggregate thickness of 01 igocene and younger sediments exceeds $17.6 \mathrm{~km}(58,700 \mathrm{ft})$ in coastal Louisiana (Figure IV-A-2). This enormous mass was deposited over some 37 million years (Jones, 1975).

The filling of the Gulf Coast geosyncline was accomplished in eight major cycles of prograding sedimentation, corresponding to eight major deltaic systems and their marine equivalents. The principal area of deposition during the early Cenozoic was the Texas coastal plain and the 


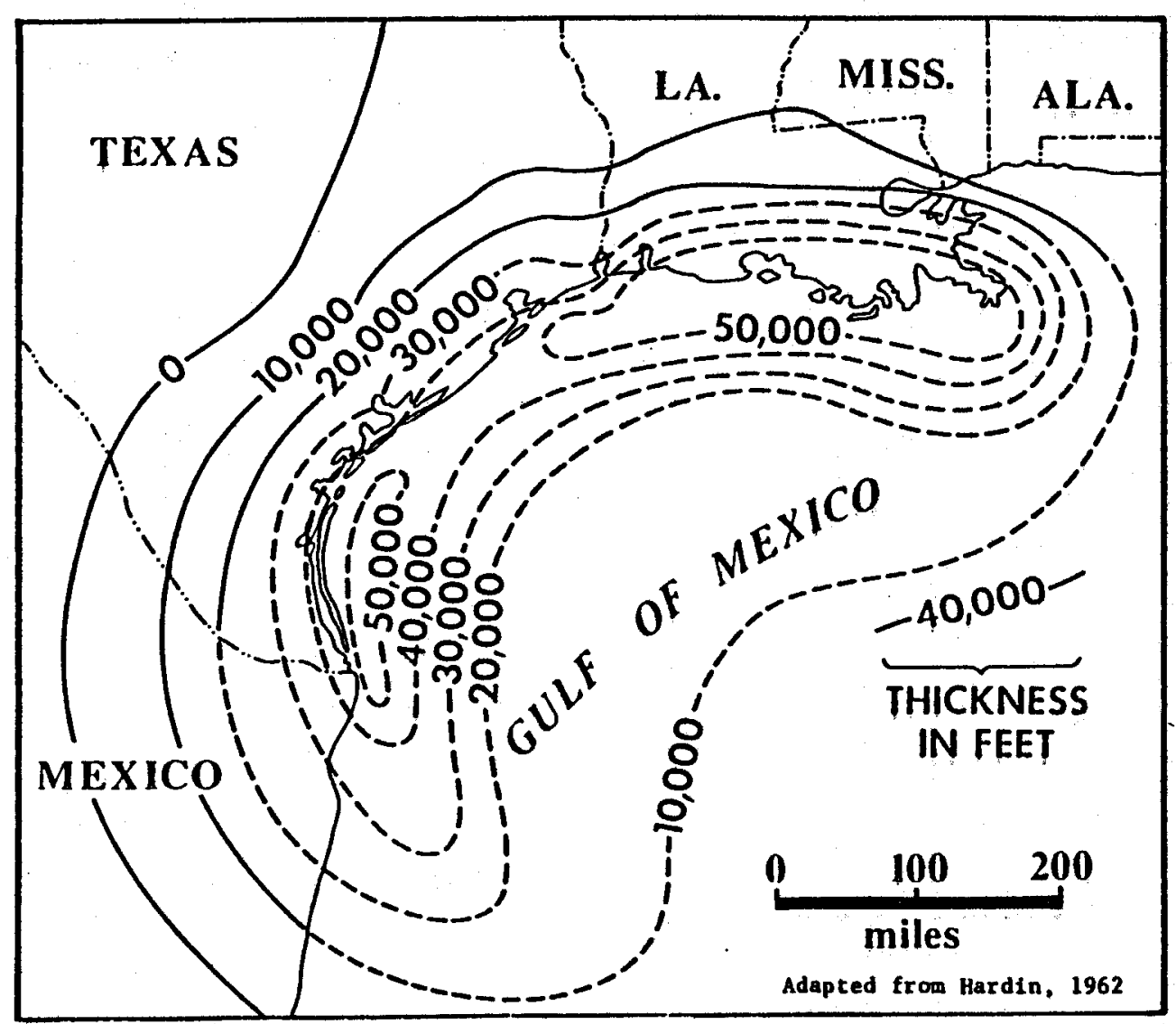

g

Fig. IV-A-2. Thickness of Cenozoic deposits in the Gulf Coast geosyncline. (Fom Jones, 1975). 
adjacent Gulf continental shelf and slope; the rivers that provided the sediments ranged widely between the Sabine Uplift and the Rio Grande. Since early Miocene time, the Mississippi River system and its precursors have drained the central North American continent and have deposited sands and clays in the Gulf Coast geosyncline underlying what is now the Louisiana coastal plain and adjacent Gulf continental shelf and slope (Jones, .1975).

As each younger deltaic system overrides its predecessor, a wedge of deposits is formed which gradually thickens gulfward. Fluvial sandy deposits accumulate at the gulfward extremity of each wedge, thickening downward along shear zones that cut deeply into prodelta and marine clays of older deltaic systems (Jones, 1975).

Basically, the shear zones (faults) develop as the prograding sandy deposits begin to overload the undercompacted older shales which lose water, as in a filter press. Loss of such interstitial water leads to compaction in the overloaded shales and maintanence of a normal fluid pressure gradient with depth. Therefore, increasing sedimentation is accomodated by progressive subsidence of the geosynclinal mass due to compaction. The subsidence rate is reduced or temporarily stopped and fluid pressure becomes abnormally high (geopressured) when there is resistance to water expuision from deeper deposits due to low permeabilities in the shales and isolation of sand bodies within shales.

The fluid pressure distribution within the Gulf coast geosyncline can be subdivided into the upper hydropressured zone and the deeper geopressured zone. In the hydropressured zone, fluid pressures are in equilibrium with the surface of the earth, as if an open pipe existed from the surface to a depth within the hydropressured zone. The fluid pressure at any depth is, therefore, hydrostatic and dependent solely on the weight 
of the water column. In the geopressured zone, fluid pressures are greater than hydrostatic because there is a lack of fluid communication to the surface, or at best a restricted connection, either of which results in a. part of the rock column being supported by the interstitial fluids within the rocks.

Jones (1975) states further that this cycle of deposition, water expulsion, downwarp, shear, and progressive rotation of deposits into the fault plane (with resulting reversal of dip) and stabilization (at least for a time) characterizes the contemporaneous fault zones of the Gulf basin. Locally, these faults are called "growth faults". Sand beds in the downthrown blocks drain adjacent shale beds and discharge water into the master faults which are connected upward with the hydropressure zone--probably via a complex and little-known network of branching faults. This cycle was repeated at differing scales in the distal parts of each major delta system, and the depositional processes define the geometry of the sand-bed aquifer systems in the down-thrown blocks. In plan, growth-fault zones of the northern Gulf basin trend roughly parallel to the modern shoreline. Although individual faults are discontinuous, the fault zones are continuous for hundreds of kilometers.

The depth to the top of the geopressured zone generally increases with age of the sediment (Figure IV-A-3). Jones (1975) gives the reasons for this as follows: "This is because the drainage of the younger Tertiary growthfaulted deposits is less advanced than in the older deposits, and the volume of the deposits formed in the younger cycles was progressively greater. The top of the geopressured zone in Quaternary deposits may be very shallow or very deep, depending upon sediment facies. Drainage is at a very early stage, the size of the depositional mass is very great, and the relative amount of coarse-grained material is large." 


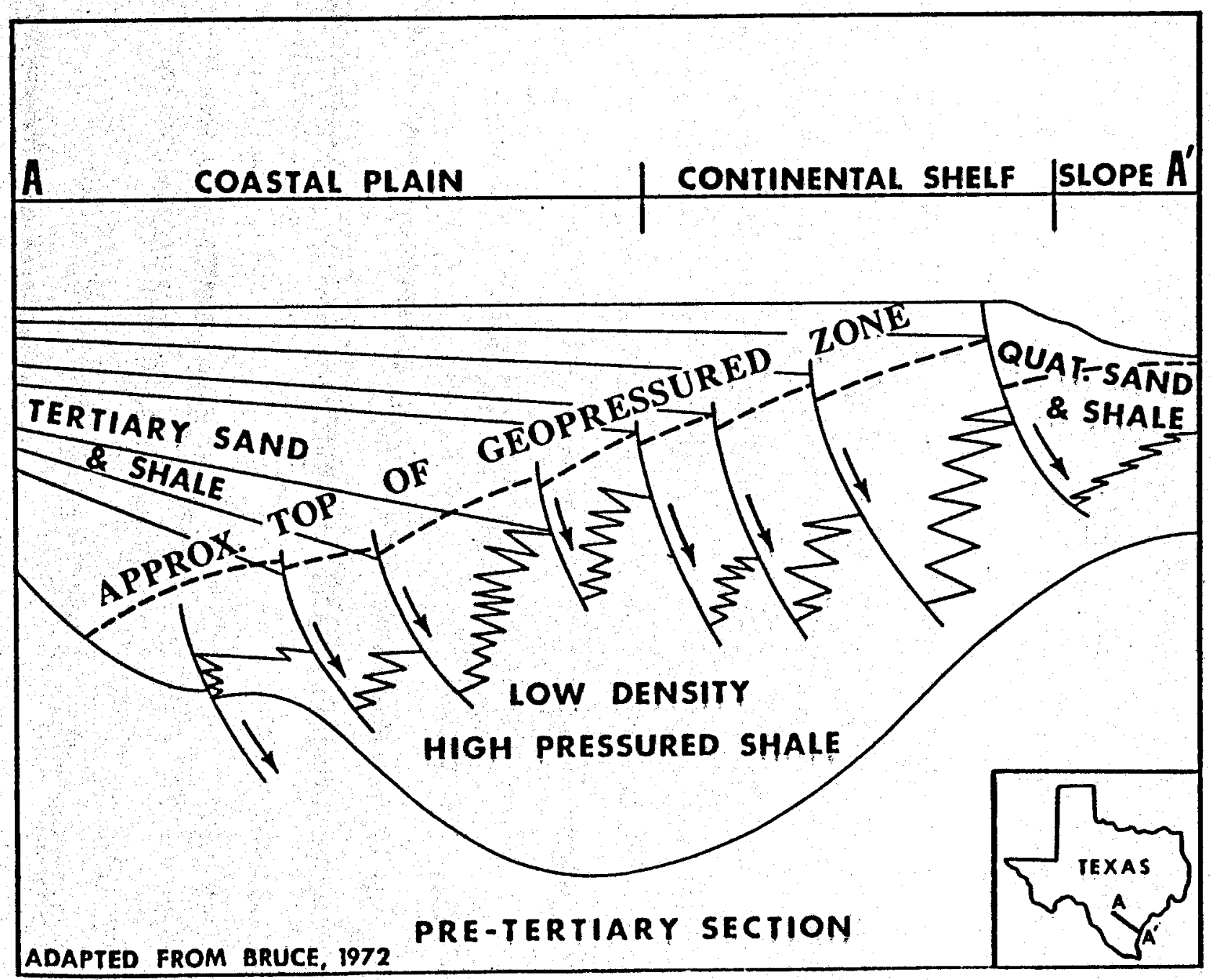

Fig. IV-A-3. Geologlc dip section across South Texas Coastal Plain. (From Jones, 1975). 
In profile, fault planes are concave upward and gulfward (Figure IV-A-3). During rapid burial, increasing fluid pressure in the fine-grained deposits reduced their resistance to shearing stress and faulting occurred. The dip angle is high where fluid pressure is low, and may be as high as $60^{\circ}$ at the top of the geopressured zone; deeper, where the fluid pressure is much higher, the dip is only about $15^{\circ}$ (Jones, 1975).

Thermal diagenesis of clay minerals, especially montmorilionite, results in the release of bound and crystalline water when the temperature exceeds $100^{\circ} \mathrm{C}$. The volume of water released by clay-mineral conversion may be 10 to 15 per cent of the compacted bulk volume of the rock (Burst, 1969). Expulsion of enormous volumes of water can therefore take place, accompanied by volumetric reduction at depth through upward escape of hot, high-pressure water via fault planes. These mechanisms make possible rapid, large scale subsidence of fault blocks with attendant vertical and horizontal components of movement. Superheated waters released to the hydropressured zone aquifers heat adjacent clay beds, causing progressive thermal diagenesis of montmorillanite in them, thus releasing water and triggering new shearing stresses and additional faulting. The faults serve as a valve to release fluids when pressures exceed a critical value near the lithostatic load, or to trap fluids by remaining closed until fluid pressures again exceed near-lithostatic values (Jones, 1975).

\section{b. Hydrodynamic Regime}

The hydrodynamic regime of the northern Gulf of Mexico basin is a function of two regional hydrodynamic systems (Jones, 1975):

(1) geopressured zone--fluid pressures reflect part of the weight of the rock overburden. 
(2) hydropressured zone--fluid pressures reflect weight of super incumbent water column and back pressure of out-flowing water.

The geopressured zone is the largest. Leakage from the geopressured zone affects the hydropressured zone because all water that escapes from the geopressured zone must pass through the hydropressured zone to reach the surface. In deposits of the hydropressured zone, a loss of porosity occurs with increasing depth. Also, compaction increases with increasing depth along with expulsion and upward discharge of water. Permeability decreases with increasing depth, causing an increase in hydraulic head required to cause fluid discharge and thus an increase in interstitial fluid pressure. Loss of permeability with depth is offset somewhat by a decrease in viscosity of pool waters with rising temperature (Jones, 1975).

Waters in geopressured zones decrease in salinity with depth which increases effective permeability. This salinity gradient is due to the concentration of dissolved solids in the upper geopressured zone caused by the hyperfiltration of waters within the shales at the geopressured-hydropressured boundary (Jones, 1975).

An abrupt increase in porosity occurs when passing downward from a hydropressured zone into a geopressured zone - up to 10\% increase in porosity. The porosity change in the geopressured zone is a function of changing pore pressure of the interstitial fluids (Jones, 1975).

The pressure gradient in the Gulf Coast is normally about $107 \mathrm{~g} / \mathrm{cm}^{3}$ $(0.465 \mathrm{psi} / \mathrm{ft})$. Until about 1950 , many wells blew out upon reaching a geopressured zone. Modern technology enables drilling into geopressured zones because of better methods of pressure prediction below the drill bit and improved drilling methods. 


\section{c. Hydrothermal Regime}

An important aspect of the geopressured energy resource is the relatively high temperature of the geopressured waters. In general, water carries out the major role in the redistribution and subtraction of heat in the geothermal field (Bogomolov, 1967). Because water surrounds mineral grains, heat flow is a function of the mass transfer of water. If water is held motionless the heat flow is reduced. The temperature increase with depth is approximately linear within the hydropressured zone in the Gulf basin. In the geopressured zone, the gradient is cormonily 2-3 times greater than in the hydropressured zone (Jones, 1975).

Bottom-hole temperatures measured in wells can be used to produce maps showing isothermal surfaces, and to identify the areas in which hightemperature water may be found at shallow depths. The $66^{\circ} \mathrm{C}$ isotherm is always within and near the base of the hydropressured zone and the $93^{\circ} \mathrm{C}$ isotherm is always within or near the top of the geopressure zone (Jones, 1975).

The isotherms of the geopressured zone may upwarp in areas where water leaks up fault planes. Upwarping of isotherms may also be caused by the updip movement of water in sandy deposits. The top of the geopressured zone rises gulfward and sinks landward (Figure IV-A-3).

\section{d. Hydrochemical Regime}

Dissolved solids in the geopressured water may be potentially harmful to the surface or ground-water environments. High salinities may exist in geopressured waters, because the expulsion of water from shales with porosities less than $45 \%$ is restricted by hyperfiltration (Jones, 1975). This restriction in flow and resultant increase in salinity is created 
by osmotic pressure which opposes the flow and is created by the finegrained sediments behaving as semipermeable membranes. Jones further states: "The selective retention of ionized dissolved solids within clay beds from which water is expelled by compaction (with increasing depth of burial and over-burden load) produces an osmotic pressure gradient resisting compaction as water squeezed into adjacent sand beds is freshened."

A very large gradient in head is present between the geopressured zone and hydropressured zone. The resistance of a clay bed to compaction (i.e., its load bearing strength) depends upon the salinity contrast between the clay pore-water and water in the adjacent sand beds. Any change in salinity of water in sand beds could result in a delayed or an accelerated compaction of adjacent clay beds, depending upon the resulting pore-water salinity contrast. The escape of high-salinity water from a geopressured zone upward along fault planes can increase the salinity of water in basal sands of the hydropressured zone. This process has flushed the geopressured zone of high-salinity water in broad areas (Jones, 1975).

The large-scale release of fresh water from clay beds into sand beds of the geopressured zone is the result of clay mineral diagenesis at elevated temperature. This process reduces the load-bearing strength of clay by converting bound and crystalline water to fresh pore water that is able to drain from the clay bed without hyperfiltration resistance. The $1000 \mathrm{C}\left(212^{\circ} \mathrm{F}\right)$ isotherm triggers the thermal diagenes is of montmor$1110 n i t e$ and liberates fresh water that slowly rises as a front through the deposits. The upward flush of fresh water drives salty connate water ahead of it, sweeping salt water upward. Loss of salty water from the geopressured zone has caused widespread freshening of water in sand beds at 
great depths. If water from one of these fresh-water areas of the geopressured zone escapes, it may flush the hydropressured zone.

\section{e. Hydrocarbons Associated with Geopressured Zones}

A major source of energy from geopressured waters should be dissolved methane. Petroleum hydrocarbons are formed by al teration of organic matter; the rate of hydrocarbon generation increasing with depth. The temperature at which hydrocarbon generation begins depends upon: (1) type of organic matter, (2) sediment type, and (3) time-temperature regime. The depth at which conversion begins depends on the geothermal gradient (Figure IV-A-4).

In the geopressured zone, the thermal diagenesis of montmorillonite in slay beds releases water as pore water which moves out of the clay beds and moves upward along fault planes toward the top of the geopressured zone. At the same time that montmorillonite is dehydrated, thermal maturation of hydrocarbons occurs in the clay beds. The saturated hydrocarbons are dissolved in the high temperature waters of the geopressured zone and are carried out of the clay beds as a hydrocarbon-water solution. Methane, which is soluble in water at high temperatures and pressures, is generated in large quantities and saturates the water of the geopressured zone. Hydrocarbons dissolved in water may move upward along growth faults which cut the clay-bed seal of the geopressured zone and move into the transition zone between the geopressured zone and hydropressured zone. As the highpressure water enters sand beds cut by the faults, solution pressure drops and hydrocarbons exsolve and accumulate, if a suitable trap is present. 


\section{Potential Environmental Impacts}

a. Subsidence of the Ground Surface.

In southern Louisiana, the ground surface has low relief and low elevation above sea level grading down to marsh lands at or slightly below sea level. Even small amounts of subsidence, therefore, may cause significant and widespread effects in the environments of such areas. Natural geological, pedological, and biological processes combine to produce slow and continuous subsidence in the Louisiana coastal zone (Adams, et a1., 1976). Extraction of fresh water for human and industrial consumption has contributed to subsidence near several large population centers in Louisiana (Smith and Kazmann, 1978; Wintz, et.al., 1970; Kazmann and Heath, 1968). 011 and gas production causes local subsidence over some fields, but not others, although systematic studies of many fields seem to be lacking.

Problems resulting from subsidence can be grouped as follows: damage or displacement of man-made structures within the subsiding area or along its margins (discussed in section VIII); (2) changes in groundwater levels and hydrodynamics; (3) widespread changes in the character of the land surface and, potentially its value as defined by its biological productivity (discussed in section VII); and (4) possible (though unlikely) earthquake hazards.

None of these problems can be predicted with any certainty based on studies of natural phenomena, and it is possible that each problem could be initiated or augmented in any area of geopressured water production. In view of this uncertainty and the considerable impacts that subsidence in coastal Louisiana would generate, the state agency charged with regulating 
geopressured resource development (Louisiana Department of Natural Resources; Office of Conservation, 1978) has proposed regulations that will require the collection of baseline data on surface elevations and reservoir and overburden characteristics. Specifically, fourth order levelling results must be filed annually, and a gamma ray-neutron log must be run initially. The proposed rules give the Office of Conservation authority to require additional data if subsidence is evident during production (Harrel1, 1978). Harrell also has presented a detailed analysis of the substantial legal implications for producers of geopressured waters if such production is considered to be the sole or contributing cause of subsidence. It is Harrell's opinion that the geow pressured water producer could be faced with private suits for damages, or even injunctive relief, should a landowner of property adjacent to the property leased to the geopressure producer believe his or her land has been damaged due to subsidence from geopressured development. (Louisiana courts have ruled that persons leasing property for hydrocarbon production are considered to have agreed to the consequences of normal operations). Given the large risk that it appears geopressured water producers must assume in connection with the possibility of subsidence, this particular potential environmental impact is of significant concern to industry representatives in Louisiana (Christopher, Durham, Rust, Wilson; personal communication, 1977). State agency representatives with planning and regulatory functions in the coastal region of Louisiana also consider the effects of subsidence, should it occur, of major consequence (Templet, St. Amant; personal communication, 1977).

Production of geopressured waters from zones in the Louisiana Gulf Coast has the potential for causing land subsidence associated with 
tectonic adjustments along faults, or with gradual sinking due to compaction and dewatering of the rocks at depth. No studies of land subsidence and its effects due to fluid withdrawal in the deep geopressured reservoirs of the Gulf Coast have been conducted. However, some inferences regarding such possible subsidence can be made from studies of land subsidence effects due to exploitation of shallow reservoirs. Studies such as those conducted by Gabryscb and Bonnet $(1974,1975)$, in the Houston-Galveston area, indicate that the potential exists for horizontal and vertical land-subsidence effects due to withdrawal of large quantities of fluids from a geopressured reservoir. Hunt (1970) indicates that the surface area affected by subsidence may be much larger than, and may be offset laterally from, the area of maximum geopressured water production. Because of the magnitude (areal extent) and consequences ( 1 and loss due to submergence, and ecosystem effects) of the subsidence problem, it is recommended that several in-depth programs for establishing baseline data and for monitoring land subsidence changes in the Louisiana Gulf Coast be considered.

Difficulties will be encountered when attempts are made to isolate subsidence effects due to geopressured water production from those caused by natura 7 and other man-induced processes. Extensive lowering of the land surface in the Louisiana Gulf coast results from:

(1) Regional subsidence due to natural sedimentary loading causing geosynclinal downwarping, natural processes of sediment compaction, and natural tectonic processes (growth faulting, folding, fracturing, and flowing).

(2) Man-induced subsidence due to the withdrawal of subsurface fiuids from relatively shallow reservoirs (less than 5,000 feet deep), principally ground water for frrigation or industrial use.

(3) Local subsidence caused by the mining of sulfur and salt from relatively shallow depths. 
(4) Subtle and often unrecognized subsidence due to the withdrawal of 0i1, gas, and formation waters from deep normally-pressured reservoirs, as well as from geopressured reservoirs.

(5) Subsidence resulting from volume reduction of organic soils and sediments; volume reductions as great as 85 per cent due to oxidation, dehydration and erosion in march soils are not uncommon.

Figure IV-A-4 shows preliminary estimates of elevation change--the surface expression of these processes--in the entire Gulf Coast region.

Efforts to separate each component of subsidence should be made in order to delineate baseline levels of subsidence for different producing fields or geographic areas. One approach could be to establish the background subsidence levels as a constant and then compute activity due to geopressure reservoir exploitation. Another possibility would be to select sites that are away from any producing water or mineral fields. Research on fluid-pressure decline in shallow subsurface aquifers indicates that ground movement may include both horizontal and vertical components. Subsidence and other forms of deformation occur as a result of compaction of unconsolidated sediments and/or deep-seated tectonic readjustments triggered by fluid withdrawal (Lofgren, 1977).

The magnitude of the compaction depends upon characteristics of the deposits and applied stresses such as: (1) the compressibility of the deposits, a function of their physical and chemical properties; (2) the nature, magnitude and history of stress application; and (3) the thickness of the compacting interval. Knowledge of assumed field parameters and laboratory information from analyzed mechanical properties of the reservoir system can be utilized to model subsidence effects, but data are sparse and such models are in the early stages of development. 


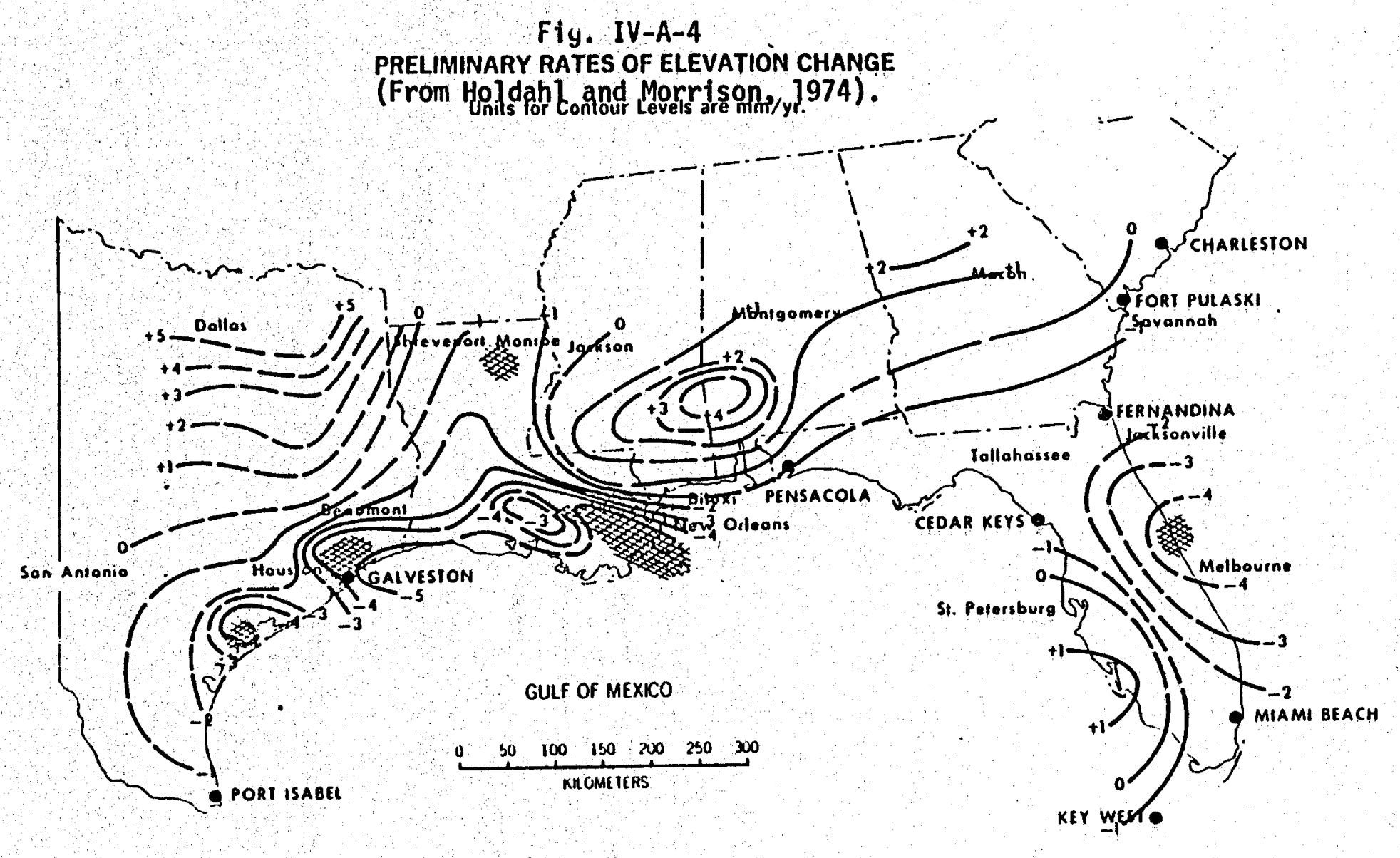


Effective changes in fluid pressures of reservoirs, possibly correlated to the net volume of fluids extracted, are an important factor contributing to formation compaction and land subsidence. In the Texas and Louisiana Guif Coast region, few unequivocal correlations have been made between heavy development of deep oil and gas fields and land subsidence. Failure to detect subsidence effects in these areas of deep fluid withdrawal must be accounted for by one or a combination of these conditions:

(1) field data are not adequate to show subtle changes of the land surface, or sufficient scrutiny of the data has not been made.

(2) ground movements, perhaps along growth faults, has accounted for part of the assumed formation compaction.

(3) stress changes in the reservoir system are minimized by fluid circulation replacement of withdrawn fluids.

(4) very low compressibility of the formation, due to physical and chemical aspects of grain arrangement, leading to low compaction, and hence to little or no subsidence.

Geertsma (1973) considers the causes of subsidence above oil and gas reservoirs, a method for estimating order of magnitude of compaction and subsidence, and a review of prediction of subsidence. Also he demonstrates that land subsidence due to hydrocarbon production seldom leads to serious subsidence and pinpoints potential problem areas. There is no way to directly apply Geertsma's conclusions to geopressured water production because of the great differences in volume and rate of production compared to normal oil and gas production. However, his data and conclusions may be indicative of the kinds of problems to be encountered during geopressured water production. 
Geertsma reports that some or all of the following conditions are fulfilled when considerable subsidence occurs in oil and gas fields:

1) significant reduction in reservoir pressure during production period;

2) production is from a large vertical interval; 3) oil or gas, or both, are contained in loose or weakly cemented rocks; 4) reservoirs have small depth of burial.

Geertsma derives estimates of formation compaction, a compaction coefficient, and a deformation constant. These are useful in estimating the magnitude of compaction and subsidence, and can also be usefut when combined with other parameters in predicting subsidence. An estimate of formation compaction is expressed as a change in reservoir height relative to the initial height. The compaction coefficient is the change in reservoir height divided by the product of initial height and pore pressure. The deformation constant is derived from mechanical experiments performed on core material.

Predicting a compaction distribution can be derived by combining these data: 1) lab measurements on core material in order to get a deformation constant; 2) map showing vertical and lateral distribution of productive zone; 3) predictions of reservoir-pressure distributions; 4) correlation of lab compaction data with petrophysical properties measured or derived from logs.

Geertsma (1973) concludes that oil reservoirs of depletion type in loose sands and extremely large gas reservoirs in either loose sediment or friable rock, are most sensitive to subsidence. However, certain "hard, strong" rocks may behave more like loose sediment or friable rocks under the reservoir conditions imposed by pressure changes related to geopressured water production. Research is in progress at many institutions 
on the complex problems of reservoir fluid dynamics and rock mechanics, al1 of which are relevant to attempts to predict ground surface subsidence caused by subsurface compaction related to fluid production.

\section{b. Faulting and Induced Seismicity (Earthquakes).}

The possible effects of geopressured water production on faulting and seismicity are closely related to ground surface subsidence caused by compaction of sediments at depth. In fact, faults (especially growth faults) are an integral part of the subsidence mechanism. The displacements of fault blocks downward allow for adjustments in the differences in stress and strength throughout the mass of accumulated sediments.

The Gulf Coast of Louisiana and Texas is generally considered to be lacking in the generation of seismic activity. Growth faults, and smaller faults antithetic to the major faults or related to salt-dome emplacement, are planes (more correctly, irregularly curved surfaces) along which deformation is concentrated as adjacent masses subside differentially. Abundant evidence from drilling and seismic exploration for oil and gas have documented the slow and continuous release of stress. With such a continuous release of stress, seismicity is normal.

Only two seismic events have been reported in Louisiana in this century (Gulf States Utility Co., 1973). An earthquake near Donaldsonville, Louisiana in 1930 registered VI on the modified Mercalli scale causing slight damage to poorly built structures. A localized earthquake near Baton Rouge in 1957 registered V on the modified Mercalli scale.

The effects on the Gulf Coast of producing geopressured water from fault blocks, and especially from rocks near faults, are unknown. Research in other areas (e.g. Colorado) has shown a relationship between injection 
and removal of fluids and seismicity (Evans, 1970; Raleigh, 1972). It is possible that reducing the pore pressure in geopressured reservoirs will produce a "locking" effect on the nearby faults thus perhaps allowing the accumulation of stress along the fault zones. After reaching a certain (but now unknown) critical stress value, the fault blocks might slip past each other in such a way as to cause a (probably) small earthquake. A less drastic release of the accumulated stress might result in many small "earthquakes" or microseisms, far too weak to be felt by humans or to cause damage due to earth shock. Clearly more research is needed in this area and a seismic and microseismic monitoring program should be included in any environmental evaluation of a geopressured energy site.

Faults at the surface, or fault "lines" projected to the surface from subsurface fault data, should be monitored by ground-based instruments and surveys and by aerial photography and other remote sensing techniques. Damage to structures and changes in the landscape along the surface traces of faults are well known. As with general (perhaps more uniform) subsidence, it is likely that considerable uncertainty and potentially significant legal liability may be involved if production from geopressured reservoirs activates faulting, ef ther on old or new faults. 


\section{B. DATA REQUIREMENTS AND AVAILABILITY}

\section{Introduction}

The pre-impact assessment of the geologic effects of geopressured resource development includes collecting information for difinition of geopressured reservoirs, and providing baseline data for later monitoring of subsidence, fault activity, and induced seismicity.

\section{Data Requirements}

a. Defining Geopressured Reservoirs

In the Texas Gulf Coast, the Bureau of Economic Geology and Department of Petroleum Engineering of the University of Texas, Austin for more than two years has conducted a search for geopressuredgeothermal energy (1.e., Bebout, et.al., 1975). Their search consisted of two major phases: regional resource assessment and detailed site selection. The objective of the regional study was to outline "geothermal fairways." Geothermal fairways are areas which include the appropriate temperatures, pressures, and 1ithologies to be considered as a potential producer of geopressured waters. Fairways which resulted from regional study were then investigated further to determine reservoir size, relationship to growth faults, porosity and permeability, and nature of porosity (diagenetic fabric). From this site-selection phase, specffic locations for testing were selected.

In order to define geopressured reservoirs in Louisiana, bottomhole temperatures and pressures of a statistically appropriate number of wells have been acquired using well logs (Hawkins, 1977; Bernard, 1977). Detailed geologic mapping of prime geopressured prospects 
(reservoirs) in Louisiana is presently underway (Bernard, personal communication, 1978). Well logs would also be useful in defining lithology, porosity, and permeability of geopressured reservoirs and in locating appropriate horizons that could accept spent fluids during reinjection.

\section{b. Subsidence}

Subsidence involves a number of physical parameters, such as compaction and compressibility of sediments, which can be monitored in order to determine subsidence resulting from fluid withdrawal. The types of data needed for studying subsidence potential of deep reservoirs in the study area include: (1) measurements of land surface elevations; (2) compressional measurements on subsurface samples: and (3) aerial photographs and other remote sensing data.

Leveling Surveys. Subsidence is measured as the lowering in elevation of the land surface. Three types of field data are useful in detecting and monitoring subsidence: (1) leveling surveys that are tied to a stable reference datum, such as surveys conducted by the National Geodetic Survey (NGS) and the U.S. Geological Survey (USGS); (2) surveys of tidal bench marks for monitoring isostatic sea level changes by the National Oceanic and Atmospheric Administration (NOAA); and (3) tiltmeter data which record relative vertical movement (parallel liquid-level tiltmenters) and rotation (borehole tiltmeters). Compaction. Compaction is the decrease in volume of sediments in response to an increase in effective stress. Predominately one-dimensional vertical consolidation occurs for thin formations of considerable lateral extent. Two techniques are useful for measuring compaction:

(1) Measurement of bench-mark subsidence gives a direct measure of net compaction at the surface which may be the result of differential 
compaction at one or more depths.

(2) Repeated well log surveys that can define density increase or porosity decrease in specific rock units or can show subsurface subsidence of certain rock layers compared to well casing joints.

Compressibility. Reservoir compressibility is a critical parameter for estimating compaction and subsidence. Data from field measurements of compaction and laboratory consolidation tests of core samples are useful in estimating formation compressibilities.

Change in Effective Stress. A decrease in formation fluid pressure caused by production of geopressured fluids results in a corresponding increase in effect stress on mineral grains in the rocks (Lofgren, 1968). A record of formation-pressure decline is a measure of the increase in effective stress tending to compact the fluidbearing deposits of the reservoir system. Drill-stem tests run on all wells when first drilled are useful tools in measuring formation pressures.

Thickness of Compressible Deposits. Based on electric logs and geologic sections available, a sequence of beds can be subdivided into iithologic units and compressibility values assigned to each unit. Volume of Fluid Produced. There is a close interrelationship among the volume of fluids produced from a particular reservoir, the fluid-pressure decline that occurs in the reservoir, and the surface subsidence that may result.

Modelling. Background data fram numerous sources is necessary In order to establish baseline data for numerical modelling studies of 
subsidence. Computer techniques are available for studies of this kind once suitable data have been acquired.

Aerial Photography and Remote Sensing. Before land loss rates caused by subsidence or other natural or induced processes can be properly evaluated, an inventory of land and water environments as they presently exist is necessary. In addition, an inventory of historical data to establish a quantitative base level of land/water changes in the past would be needed in order to isolate the future subsidence effects due to geopressured operations.

The detailed study of aerial photography and other remote sensors along with USGS quadrangle sheets may be useful for measuring comparative land losses over long periods within specific geographic areas. For instance, methods such as one developed by Gagliano and van Beek (1970) for determining land loss rates and marsh deterioration may be adaptable for long-term subsidence studies. In this study, aerial photographs, USGS quadrangle sheets, and USGS orthophotoquad sheets were evaluated by a point-counting system to determine changes in land/water ratios over time periods of approximately 15 years.

Evaluation of historic data from early USGS quandrangles and aerial photography can furnish information on past levels of land loss due to subsidence or other processes. Likewise, the most recent coverage by maps and sensors can serve as a base for future environmental inventory.

\section{c. Fault Activation and Seismicity}

Impact on the environment due to fault activation and induced seismicity is a complex problem which could result from fluid 
withdrawal and/or subsurface disposal. Since no historical monitoring of fault activation and seismicity on the Gulf Coast has been conducted, baseline data requirements would have to be obtained during the preimpact period. A network of tiltmeters periodic study of aerial photographs and ground leveling surveys would provide some of the data necessary to monitor any possible faulting. Since no seismic stations exist in the Louisiana coastal area, establishment of a seismic monitoring system would be required to observe any seismicity.

\section{d. Post-impact Data}

The data requirements for post-impact evaluation of subsidence involves the monftoring of established pre-impact parameters. For example, leveling surveys that are tied to a stable reference datum would require periodic re-surveying to establish existence of subsidence. Likewise, any baseline data concerning faulting and induced seismicity as outlined in the previous section would need continuous updating. Evaluation of the effects of fluid reinjection necessitates the monitoring of the same parameters included in monitoring faulting and seismicity.

\section{Data Availability}

Below is an outline of the avallability of data required for assessment of the geologic effects of geopressurcd development on the Louistana Gulf Coast

a. Location of Faults in Louisiana

Location of faults on and beneath the surface would be very useful in addressing the problems of subsidence and fault activation due to fluid withdrawal and/or subsurface disposal. Although the extent of 
coverage is unknown, detailed maps of Louisiana locating faults are available through Geomaps of Gulf Coast, Inc., Houston, Texas.

b. Well $\log$ Acquisition

Interpretation of well logs is essential to defining target geothermal/geopressured fairways. Information such as lithology, porosity and permeability, and sometimes temperature, is available from well logs.

Weli logs may be obtained for viewing from either the Louisiana Geological Survey, Baton Rouge or the Louisiana Department of Natural Resources, Office of Conservation, Baton Rouge. The state Survey has in its files only those logs which it has utilized in past and present projects. A complete log library containing all well logs filed with the state of Louisiana can be found at the Office of Conservation. However, not all logs filed with the office are available for public inspection. The oil and gas industry has the right to hold its logs confidential. Almost all logs from offshore are held confidential and onshore logs at depths greater than 15,000 feet can be held confidential for a longer period than logs of wells shallower than 15,000 feet. Most onshore logs are available to the public although a few onshore logs are held confidential.

c. Information Available in Annual Summaries of Field Statistics and Drilling Operations in Louisiana

Annually the Louisiana Office of Conservation compiles and publishes a summary of field statistics on drilling operations which occurred in Louisiana during the year. Included in the report are: (1) district and state summaries for the year; (2) a list of new field 
discoveries; (3) field statistics by onshore conservation districts and offshore; (4) a salt water disposal and disposition report; and (5) a miscellaneous well report.

The district and state summary includes such information as: number of wells drilled, number of oil well completions, number of gas well completions, number of multiple completions, number of field wells drilled, number of field wells drilled dry, number of wildcat wells drilled, number of discoveries, field footage drilled, wildcat footage drilled, average depth per well drilled, average depth per field well, and average depth per wildcat well. All of the above statistics are summarized for each state district and for the entire state.

The list of new field discoveries per district includes statistics on: operator, lease and well number, location of the well, completion date, total depth, producing depth, daily rate of production and other production data, and geologic age of producing formation.

The summary of field statistics by district includes such information on specific fields as; field name and parish; name, age, and depth of producing formation; year of discovery; estimated area proved; number of wells; number of wells producing at the end of the year; and deepest zone tested. Also included are statistics on the producing formations such as: of1 gravity, average porosity, producing thickness, and type of structure encountered.

The statistics on salt water disposal per field include: number of wells, average well depth, pressure range, volume of injection per year, cumulative volume of injection, parish totals and district totals. 
The statistics on the disposal of salt water produced for the year per district and state include: total amount for districts, total amount disposed in pits, total amount disposed in streams and rivers, and total amount disposed in non-potable water bodies.

Finally, a miscellaneous well report includes the number of wells per district other than oil and gas, and the types of wells (e.g., suifur).

\section{d. Extensometers}

A network of extensometers in south Louisiana could provide valuable information related to fault movements and subsidence. However, preliminary inquiry into the location of extensometers in south Louisiana has not located one.

e. Research and Development Programs in Geothermal Resources

Several federal government projects have been initiated since 1973, which include specific concerns such as brine disposal, subsidence related to fluid withdrawal, subsurface temperatures, hydrology, and remote sensing of prospective geothermal/geopressured areas. These studies would be useful in providing background material and data sources for site-specific studies in Louisiana. The USGS is actively involved in a five year program initiated in 1975 to study the ramifications of brine disposal. In 1973 the USGS began a Gulf Coast study which includes defining subsurface temperatures and hydrologic parameters. The USGS is also involved in studying the effects of fluid withdrawal on subsidence and seismic activity in the Imperial Valley, California. 


\section{f. Status of Photographic and Other Remote Sensors}

The compilation of information presented in this section was taken from several sources and inventories of photographic and sensor data. Much of this information is also presented in "Planner's Mapping Guide for Louisiana", a publication of the Louisiana State Planning Office (1975). This guide consists of an inventory of many types of maps and mapping tools, and also indicates the amount of state-wide coverage for each item. Supplemental information concerning remote sensor coverage for the study area obtained by personal communication with Dr. A. J. Lewis (LSU, 1977) is also included. Undoubtedly more photographic and sensor information exists, including proprietary information belonging to private companies which is not available; and coverage by government agencies that is not generally known, and therefore cannot be included at this time.

Agricultural Stabilization and Conservation Service (ASCA)

Aerial Photography. The Agricultural Stabilization and Conservation Service (ASCS), a part of the U.S. Department of Agriculture, has avallable probably the most extensive low altitude aerial photographic coverage of the study area. Individual photographs are available at a scale of 1:20,000 for aerial photography before 1971. After 1971, ASCS converted to $1: 40,000$ scale photography. Most parishes have coverage from at least 2 time periods, at approximately 10 year intervals. The ASCS office in Alexandria, Louisiana, maintains a complete set of the index sheets for Louisiana. These sheets are available for public inspection. The LSU Geoscience Library serves as a repository for older ASCS photographs. 
Five of the thirty parishes included in the study area have no aerial photographic coverage by ASCS. These parishes include the urban areas of Baton Rouge and New Orleans and environs. Twenty-seven per cent ( 8 parishes) have been covered twice by ASCS flights. Seven parishes have coverage from 3 time periods. Ten of the parishes have coverage from 4 different flights. All ASCS coverage extends from 1939 to 1968.

\section{U.S. Geological Survey Low Altitude Aerial Photography. The} U.S. Geological Survey has been using low altitude aerial photography to facilitate topographic mapping since the 1940 's. The coverage dating from 1947 to 1972 includes standard photographic imagery, usually at a scale of 1:24,000. Approximately $18 \%$ of the study area is covered by these photographs.

Since 1975, the USGS has published aerial photographic coverage in the form of orthophotoquad and orthophotomap prints. The scale and format of these prints is the same as the convential 1:24,000 USGS topographic maps. Orthophotoquad prints are usually produced from uncontrolled photo mosaics by bringing the mosaic to a defined scale, relating it to a geodetic reference system, and providing a map border. The orthophotomap prints have color-enhancements of district physiographic features, such as the limits of marshlands, boundary of salt-water encroachment, fault lines and other prominent geologic and biologic features. The orthophotomaps are also enhanced with the conventional cartographic symbols used on line maps. Coverage of the study area by orthophotomaps is approximately 28\%; and by orthophotoquads, approximately $11 \%$. Because it includes both photoimagery and 
and topographic detail, the orthophotomap format is the most useful for environmental inventory studies. Production costs for acquiring new orthophotomaps range from $\$ 15,000$ to $\$ 30,000$ per $71 / 2$ minute quadrangle, depending upon topographic detafl and accessibility to the area being mapped (Schwertz and Larimore, 1976).

High Altitude Aerial Photography. High altitude photography generally shows less detail than photoimagery of a larger scale. The extensive coverage of the study area by aerial photography of a scale smaller than 1:56,000 may, however, warrant its use in connection with this study. The U.S. Geological Suryey has avallable high altitude aerial photography at scales of $1: 56,000$ to $1: 80,000$ for approximately $8 \%$ of the study area. High altitude imagery for the entire study area is also available from NASA. From 1972 to 1974 , black and white, color, and color infrared photography was taken at a scale of 1:130,000. The majority of this photography is of high quality and good resolution and can be enlarged satisfactorily. Additional coverage at different times is available from various NASA flights.

The EROS Applications Assistance Facility in Bay St. Louis, Mississippi, includes a remote sensing reference library; a LANDSAT I and II Satellite Imagery Browse File; a computerized interrogation sys tem for LANDSAT I and II, NASA, and U.S. Geological Survey photography, and various photo-interpretation/enhancement instruments which are available for use by the general public (Schwertz and Larimore, 1976).

\section{Status of Topographic Map Coverage}

In order to quantify the amount of subsidence in any area, it is necessary to measure the net change in elevation during a specified 
time interval. As discussed earlier, analysis of old and recent topographic maps of the USGS may yield data on natural rates of subsidence in the Louisiana Gulf Coast area and serve as a base for subsidence monitoring studies.

Topographic surveys for establishing vertical control and delineation of relief differences in the low lying coastal area are referenced to the mean tide sea level position. Considerations of changes in this datum, 1.e. subtly eustatic or isostatic changes in sea level, and methods to calibrate such effects, are necessary.

Topographic mapping produced by the federal government is considered to be the most accurate and the best available. Federal agencies making topographic maps include the U.S. Geological Survey, the U.S. Army Map Service, the U.S. Army Corps of Engineers, and the National Geodetic Survey (Schwertz and Larimore, 1976).

U. S. Geological Survey Topographic Maps. Coverage of the entire state between 1961 and 1966 is available on the 1:250,000 scale. However, because the lowest elevations delineated on these maps are greater than 25 feet above sea level, these maps have only limited usefulness.

Fifteen-minute quadrangle maps on a scale of $1: 62,500$ are available for approximately $83 \%$ of the study area. These maps are usually printed in color and have a 20 -foot or 5-foot contour interval. A large number of 15-minute quadrangles were published from 1953 to 1964. Approximately $46 \%$ of the study area has such coverage from two or more different time periods. The oldest coverage, those maps 
published in 1930, are available for the Lake Decade, Maringouin, and Lake Chicot quadrangles.

A series of $71 / 2$-minute quadrangles, produced at a 1:24,000 scale, are the most detailed maps available. These maps are produced in three formats: (1) the standard color line maps, (2) black and white orthophotoquads, and (3) color enhanced and cartographically finished orthophotomaps. Approximately $70 \%$ of the study area (including al1 of the area not covered by the 15-minute quads) is covered by this series of maps. Approximately $42 \%$ of the areas have duplicate map coverage from two to as many as four different years. The oldest coverage by 7 1/2-minute quadrangles was published from 1932-1934. It includes an area of approximately $2500 \mathrm{~km}^{2}\left(1,000 \mathrm{mi}^{2}\right)$ west of Marsh Is land in southwest Louisiana. Recent coverage from 1973 to 1975 is available for these areas: (1) approximately $34 \%$ of the study area west of longitude $93^{\circ} \mathrm{W}$ as photorevised maps or orthophotomaps; (2) approximately $3500 \mathrm{~km}^{2}\left(1,350 \mathrm{mi}^{2}\right)$ of Mississippi Delta below New Orleans, $2000 \mathrm{~km}^{2}\left(750 \mathrm{mi}^{2}\right)$ of south-central Louisiana, and $600 \mathrm{~km}^{2}\left(250 \mathrm{mi}^{2}\right)$ near Loreauville as orthophotomaps.

U. S. Army Corps of Engineers Topographic Maps. Topographic coverage of the lower Mississippi River Basin at a $1: 62,500$ scale is available from the U. S. Army Corps of Engineers. This series covers approximately half of the study area. Corps of Engineers maps differ from the standard USGS 15 -minute quadrangle sheets in that they include navigational and flood control features. Similar maps at a $1: 250,000$ scale are available for the entire state. 


\section{h. Status of Leveling Surveys}

Precise leveling surveys by the National Geodetic Survey will be useful for detection and monitoring subsidence if the existing lines cross areas of geopressured production. In general, leveling surveys in the coastal and low-lying areas are of three types: (1) local traverses that measure elevation differences of bench marks along the traverse - usually highway or industry surveys of low precision for engineering purposes; (2) geodetic networks of high precision of regional extent, designed to establish absolute elevations of bench marks throughout the net (Lofgren, 1977); (3) short lines of high order levels, such as the Interstate Highway System traverses.

\section{i. Additional Materials}

A number of additional published maps, bulletins, and other material are available from various state, federal, and private agencies. For some portions of the study area, geologic parameters have been investigated in detail and much useful information is available for baseline studies in connection with the assessment of geological effects of geopressured resource development. Other areas have been investigated only in a cursory manner in the past and will require extensive mapping of the geo-hydrologic and structural elements before longterm environmental effects can be determined.

\section{Geologic Bulletins (Louisiana Geological Survey)}

Howe, H.V.; and Moresi, C.K., Geology of Iberia Parish, 187 pp., 18 figs., 1931. Includes discussions of the physiography with special reference to the Pleistocene terraces and to drainage; stratigraphy, historical and theoretical considerations of the 
salt domes and associated caprock; mineral resources; and a bibliography of 224 papers.

Howe, H.V.; and Moresi, C.K., Geology of Lafayette and St. Martin Parishes, 238 pp., 52 figs. 2 pk., 1933. Under physiography, the Pleistocene terraces, Mississippi River meanders and drainage are given special attention. Stratigraphy, salt domes and prospective domes are also discussed. The bibliography contains 141 references.

Howe, H.V., et. al., Reports of the geology of Cameron and Vermilion Parishes, 242 pp., 24 figs.. 10 pls., 1935. Pleistocene Mississippi River deltas, cheniers, Gulf Coast subsidence and isostatic data of Mississippi are discussed under physiography. Salt domes and prospects; mineral development; descriptions of some microfossils; list of maps and references are also included.

Russen, R.J., et. a1., Lower Mississippi River Delta: Reports on the geology of Plaquemine and St. Bernard Parishes, 454 pp., 36 figs., $17 \mathrm{pls} ., 1936$. Includes reports on the physiography of lower Mississippi River Delta; salt domes; bibliography of 41 pages; 1ist of maps; petrographic analysis of two Mississippi River subdel tas and pebbles of Chandeleur Island; Recent mollusca; Indian mounds; and vegetation of marshes and Indian mounds.

Howe, H.V., et. a1., Reports of the geology of Iberville and Ascension Parishes, 223 pp., 25 illustrations, 1938. Report on the geology and physiography of the central portion of the existing del ta of the Mississippi River, and adjacent terraces, salt domes, bibliography, list of maps, Indtan mounds and fossils.

Holland, W.C., et, al., Geology of Beauregard and Allen Parishes, 224 pp., 28 pis., 13 figs., including colored geologic map of Beauregard and Ailen Parishes, scale 1:62,500, and structural maps, 1952. A comprehensive report on the subsurface stratigraphy, structure, and petroleum geology of the area.

Varvaro, G.G., Geology of Evangeline and St. Landry Parishes, $295 \mathrm{pp}$., 28 pls., 26 figs., and 2 tables, including a colored geologic map of the parishes, scale 1:62,500, 1957. Describes the physiography, subsurface, and surface geology of the parishes and surrounding area.

Paine, W.R., Geology of Acadia and Jefferson Davis Parishes, 277 pp., 33 pls., 8 figs., 3 tables, list of wildcat wells, 1962. Primarily a subsurface study of Tertiary geology and principally of the Frio and Anahuac Formations. Included are a tectonic map of the area with a discussion of growth faulting, regional faulting, and sedimentation; regional structure maps; and isopach maps. 
The 60 producing fields of the two-parish area are discussed in detail, and 10 field structrual maps are illustrated. Complete list of wildcat wells give pertinent statistics.

Dixon, L.H. , Cenezoic Cyclic Deposition in the Subsurface of Central Louisiana, $124 \mathrm{pp}$, $23 \mathrm{pls}$., and list of selected wells, 1965. Primarily an electric log study supporting the concept that major cycles of deposition represent the natural divisions of the Cenezoic on the northwestern margin of the Gulf Basin.

Geologic Maps. Color parish geologic maps for 6 of the 30 parishes in the study area at a scale of 1:62,500 ( 1 inch = approximately 1 mile) are available from the Louisiana Geological Survey. The maps are included in the following geological bulletins of the Louisiana Geological Survey and are not distributed separately (Schwertz and Larimore, 1976):

$\begin{array}{clr}\text { Geological Bulletin } & \text { Parish } & \text { Cost } \\ \text { No. } 27 & \text { Allen } & \$ 2.00 \\ \text { No. } 27 & \text { Beauregard } & 2.00 \\ \text { No. } 31 & \text { Evangeline } & 2.00 \\ \text { No. } 31 & \text { St. Landry } & 2.00 \\ \text { No. } 8 \text { (no map) } & \text { St. Bernard } & 1.50 \\ \text { No. } 8 \text { (no map) } & \text { Plaquemines } & 1.50\end{array}$

Subsurface Structure Maps. A number of subsurface structure maps are contained in various bulletins and pamphlets published by the Louisiana Geological Survey. Coverage is sparse in the coastal parishes and a copy of the Publications of the Louisiana Geological Survey should be consulted in identifying those parishes in which subsurface maps are available.

Surface Soil Surveys and Maps. Soil maps and taxonomic information are available for much of the study area and may be applicable for several interpretative uses. For 21 of the 30 parishes, detailed soil surveys published by the National Cooperative Soil Survey, in connection 
with the Soil Conservation Service and the U. S. Department of Agriculture, are available or are presently in preparation. Capability classes for engineering and agricultural purposes are assigned for individual soil units on the basis of soil properties such as: soil reaction, soil wetness, grain-size distribution, natural soil structure, depth to seasonal water table, plasticity index, organic matter content, mineralogy, and soil chemistry. On the basis of these properties, inferences concerning the degree of erodibility, permeability, corrosivity, subsidence upon drying, shrink-swell potential, shear strength, compressibility, and slope stability of soils and their behavior under various engineering uses can be estimated (i.e., Murphy, et. a1., 1977). Included in these parish soil surveys are $1: 20,000$ black and white aerial photos with soil mapping units cartographically outlined.

The Louisiana State Planning office has available soil subsidence maps and maps of land loss potential due to channel construction for 22 of the 30 partshes in the study area. These maps are produced on a scale of 1:125,000. Soil subsidence potential maps for the entire study area are also avallable from the Louisiana State Planning Office at the 1:250,000 scale. These maps are produced in color and are keyed to the standard USGS topographic quadrangles. All of the maps discussed in this paragraph have been prepared using information obtained from parish general soil maps published by the Soil Conservation Service. General soll maps reflect the properties of the major soil associations in the landscape. Therefore, soil property potentials are rated for 
the dominant soil bodies in the association and may not apply to variations in properties that occur in minor soil bodies. Detailed soil mapping and on-site field investigations may be needed for some areas in connection with geopressured resource developmental planning and operations. 


\section{PLAN FOR THE ACQUISITION OF DATA FOR THE ASSESSMENT OF POTENTIAL GEOLOGICAL EFFECTS.}

\section{Introduction}

The kinds of data needed to assess potential geological effects of geopressured resource development were reviewed in the preceeding section. Because such data must be site specific, the usefulness of available data is likely to be limited to tasks such as developing histories of natural subsidence in areas of interest, and compiling case histories of geological effects from fluid withdrawal and disposal from similar geological settings. Data specific to each geopressured reservoir must be generated to measure actual geologic effects as well as to predict possible geological effects. The plan proposed here focuses on the acquisition of new data with respect to potential subsidence, fault activation and seismicity (earthquakes).

The impacts of adverse environmental effects of geological events are not addressed here. Discussions of such impacts on water quality, on the biota of the study area, and on the socioeconomic and cultural environments, are included in Sections VI, VII, and VIII, respectively, with emphasis on the effects of possible ground surface subsidence. The plans in these sections (VI and VII) cover the data needs for assessing such impacts. The plan which follows in this section provides for acquisition of information on the geologic effects which are the source of impacts as discussed in the above referenced sections. This section deals with the occurrence of the geological events. We need to know in the case of subsidence, for example, whether it occurs, and, if so, how much occurs, why it occurs, and if its occurrence can be predicted. 
Three levels of effort are proposed for the assessment of geologic effects:

Level 1: Detection of Geological Events. Collection of field data to measure, detect, and monitor the occurrence of subsidence, fault activity and seismicity.

Level II: Materials Testing. Laboratory and in situ testing to determine the mechanical properties of subsurface rocks and field testing of soils will be used to aid in the interpretation of field data. The objective is to discover the causes and conditions of geological effects, and to distinguish where possible among the effects from the several underlying causes, including the development of geopressured/geothermal resources. Level II data will also be used to verify the modelling efforts undertaken in Level III work.

Level III: Prediction. Using the finite element method, computer modelling of geologic events of each reservoir will be used to provide a means for predicting their impacts on other environmental systems. Input to this effort will include the results of the Level I and Level II efforts.

\section{Level I: Detection}

Level I activities represent the absolute minumum level of effort required to assess geological effects. The objective is to determine if subsidence, fault activation, and seismicity are occurring in the vicinity of a geopressured reservoir; and, if so, how much is occurring. Data collected before geopressured fluid is produced will provide information on baseline conditions. Measurements of relative vertical and rotational movements at the surface and of seismicity will establish rates of change relative to baseline conditions. Well logs, drill stem tests, geologic and production data will also provide supporting information. Specific measurements which are planned are discussed in the following paragraphs. 
Precise Leveling. Precise leveling is essential to establish relative vertical movements of the surface, 1.e., subsidence. Annual precise leveling should be performed with the leveling network extending from the center of the geopressured reservoir to a distance approximately twice the radius of the reservoir beyond the reservoir boundaries. This large net is necessary because when fluids are produced, subsidence may form a bowl with a larger diameter than that of the reservoir. All producing wells should be tied into the network because the most severe subsidence is likely to be localized around the wells. The entire net must be tied to tidal bench marks and/or a stable reference datum, such as that of the National Geodetic Survey.

It is recommended that Second Order, Class I leveling be performed. Second order, Class I leveling has an accuracy of $6 \mathrm{~mm} \sqrt{\mathrm{k}}$ where $k$ is the distance of the line between benchmarks in kilometers. For example, over a distance of $9 \mathrm{~km}$ a vertical displacement greater than $18 \mathrm{~mm}$ could be detected. This will give the required precision for detecting vertical movement. Also, trained personel are readily available in Louisiana to perform Second Order leveling (Thoms, personal communication, 1978). Annual leveling is recommended inially. More frequent leveling can be performed later as needed. The entire network should be emplaced and the first measurements taken before fluid production begins. Any producing wells coming on line after the network has been established should be tied in to the system. Tiltmeters. It is recommended that both liquid-level and borehole tiltmeters be used in an integrated system to measure subsidence 
effects as well as fault activity. The liquid-level tiltmeter will give a precise, constant record of relative vertical movement, and is therefore appropriate for long-term, continuous monitoring of subsidence effects. Its advantages over the borehole tiltmeter are its stability and long base-length measurement capability (Huggett and Slater, 1975). The borehole tiltmeter measures surface rotation and will thus record the rotational component of surface movements due to subsidence with an accuracy in the field of $1 \times 10^{-6}$ radians (Thoms, personal communication, 1978). The borehole tiltmeter will record episodic tilts which could occur as a result of differential subsidence, fault activation, or as precursers of seismic events.

The integrated tiltmeter system should cover each cluster of producing and disposal wells and should extend outside the boundaries of the reservoir. It is likely (depending on well spacting and configuration) that several clusters of producing and disposal wells can be tied into a single liquid-level tiltmeter system. Borehole tiltmeters should be placed along major growth faults to record rapid tilts. The overall tiltmeter system should be in place early so as to obtain baseline data before production begins.

Seismic Monitoring System. A system of seismometers should be installed along major growth faults within the geopressured reservoir to monitor seismic activity possibly initiated by geopressured development. In the size reservoir used in the model presented in Section III, approximately 10 seismometers would be required. Seismic instruments similar to those used in other geopressured/geothermal areas will be appropriate (e.g., the seismic system to be used at the Brazoria County, Texas geopressured test well site under the direction of Teledyne Geotech Co., Inc., Sorrel1s, personal communication, 1977). 
Basic Geologic and Production Data. For a preliminary interpretation of data from the leveling surveys and tiltmeters, basic geologic and production data are required. Well $\log$ data will provide information on the degree of compaction associated with fluid withdrawal during the course of geopressured fluid production. Well logs and review of geologic cross sections will also provide data on thicknesses of compressible units. 3-D velocity logs and gamma ray neutron logs are recommended at minimum to provide data on material properties. The logs should be run immediately after each producing well is drilled and then repeated at 6 month intervals. Fewer (or more) logging runs can be made after the first year of production, as needed. It may be possible to estimate changes in effective rock stress from measurements of reservoir fluid pressures obtained from drill stem tests. However, it will probably be necessary to make improvements in instrumentation in order to obtain more reliable data.

Analysis of aerial photography, if available, covering a fifty year period prior to the development project would provide useful baseline information on the history of subsidence for a specific site. Also, annual aerial surveys should be made of the site to analyze post-development subsidence effects. This will be particularly useful in areas where subsidence results in the inundation of marsh.

\section{Level II: Materials Testing}

The activities of the Level II effort have as their objective the discovery of the causes of geological events as monitored in the field. Preliminary interpretations will have been made using the data collected as a result of Level I activities. 
Engineering Geology Studies. Engineering geology studies of the thermal and mechanical properties of near-surface soils are needed in order to aid in interpreting field data from the instrumentation system. For example, the data collected from the tiltmeter system are directly affected by the properties of the soils in which the tiltmeters are embedded. These effects must be understood so as to separate nearsurface natural effects from geopressured extraction effects. Then surface instrumentation data will provide maximum information for both the measurement and modelling efforts.

A number of in situ soil evaluation methods (e.g., borings, standard penetration, cone penetration, vane sheer, and pressuremeter) are available. Further study is required in order to select the system appropriate to the problem at hand.

Field sampling of soils down to 30 meters (100 feet) is recommended. Laboratory study should include testing for water content, specific gravity, void ratio, relative densities of granular soils, compressibility characteristics, thermal conductivity, shear strength and reaction moduli for analysis of stress.

Laboratory Testing of Rock Cores. Laboratory testing of rock samples from different formations should be made to determine the mechanical properties of the producing reservoirs and the overlying geologic units. The results will be used in the predictive model and are necessary to interpret the field data collected from the monitoring system. The objective of laboratory and, if possible, in situ tests of the mechanical properties of reservoir overburden rocks is to develop estimates of formation compaction, compaction coeffecients, and deformation constants for input into the mathematical model of subsidence. 
Laboratory tests should provide details on specific gravity, absorption, and mechanical behavior of rocks for stress conditions anticipated under actual field conditions.

The number of rock samples taken will depend in part on the variability of the geology in the well field. Therefore, it is recommended that a minimum of 3 wells in different sections of the field be cored to obtain adequate samples.

In Situ Rock Mechanics Studies. In situ rock mechanics studies, when possible, would be highly desirable to interpret field measurements and laboratory tests, and to provide data and verification for a model of subsidence. The objective is to measure compaction at depth in the actual temperature, pressure and chemical environments of the geopressured reservoir and overburden. It is difficult to reproduce in situ boundary conditions for rock mechanics studies in the laboratory, particularly if subsidence is due to displacements along faults which differ widely in size, orientation and spacing. Also, in situ testing is necessary to interpret scale effects in the laboratory situation.

Current methods of in situ rock testing (extensometers, casingcollar logging, and radioactive bullet logging) are inadequate for the problem at hand. Specifically, these methods are temperature sensitive, untested at the depths required, and lack the accuracy required for this problem. It is recommended that an on-going state of the art review of improvements in instrumentation for in situ monitoring at depth be conducted. The studies should be implemented as soon as adequate instruments are developed. 
Recently, downhole testing by hydrofracturing has beem employed to obtain a measure of in situ stress and formation strength at depth. This type of testing may also prove promising in the geopressured case (Haimson, 1977).

4. Level III: Prediction. The overall objective of the efforts in measurement and data interpretation is to develop a predictive capability with respect to geological effects--particularly subsidence. Subsidence is a time dependent phenomenon with asymmetric effects expected to lag considerably behind production. Because some degree of management of these effects may be possible (e.g., reinjection into different formations), operators need to know in advance of potential surface effects the degree and configuration of displacements at depth. In addition, predictions of subsidence are desirable in order to ameliorate the impacts on the hydrologic, biotic, and socioeconomic environments.

The steps in developing this predictive capability are shown in Figure IV-C-1. The first step is to develop a preliminary numerical model of the geopressured system that will simulate the reservoir and overburden response (including the surface) to production. Existing models of subsidence should be reviewed to determine if an appropriate model exists for the problem at hand. The preferred model type employs the finite element method which has been applied in the study of subsidence as a result of subsurface withdrawals (e.g., Gambolati, 1977; Geertsma, 1973; Gupta, et.al., 1975). The finite element method is particularly suited for use in geophysical problems because it assumes any continuous quantity, such as displacement, can be approximated by a set of piecewise continuous functions. This assumption allows for the following conditions: adjacent materials in the geomechanical system do 
Fig. IV-C-1. Interaction of efforts related to prediction of subsidence.

Step:

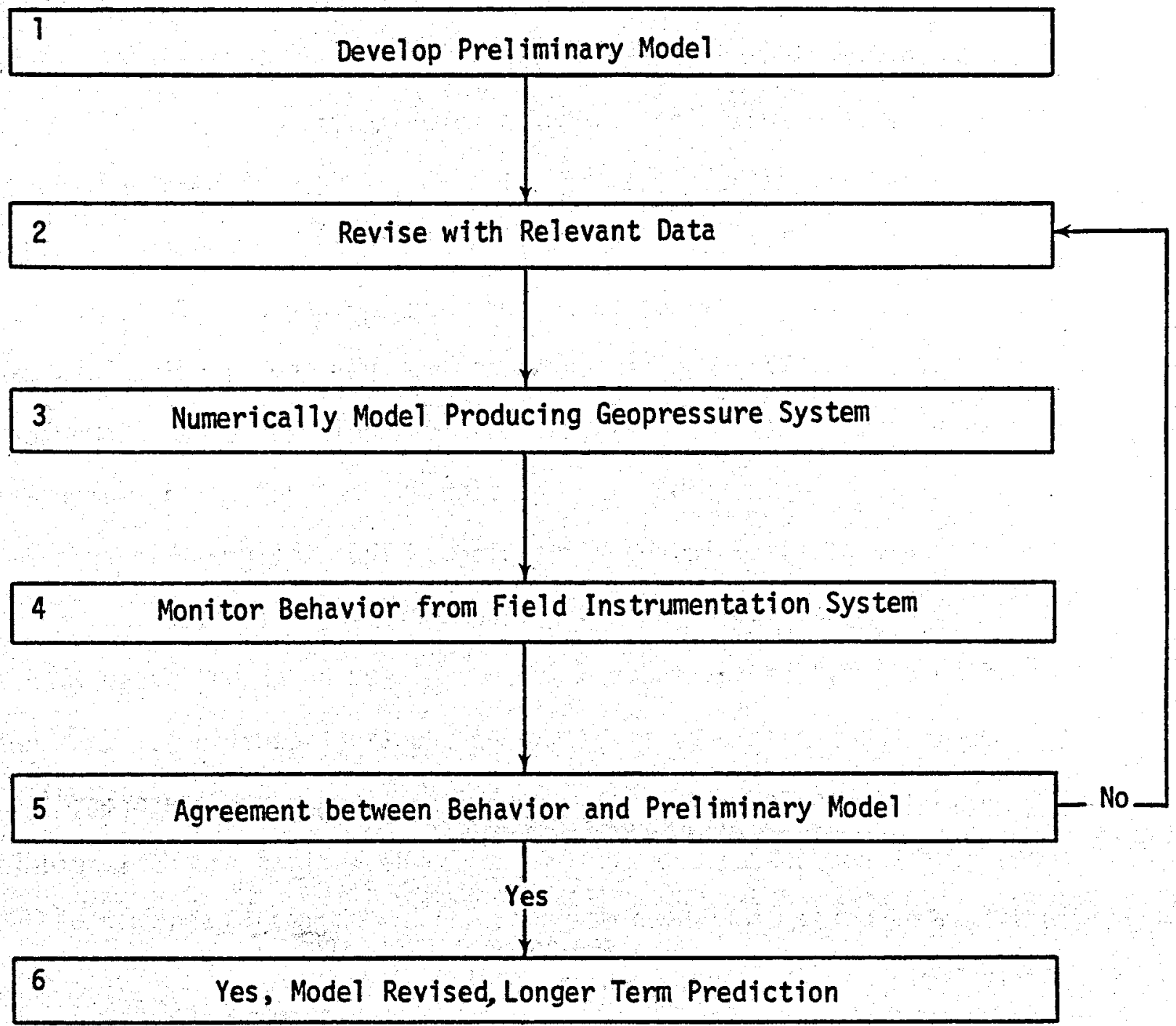


not have to be homogeneous, irregularly shaped boundaries can be utilized, the size of the elements employed in the model is variable and easily changed, and boundary conditions can be discontinuous (Segerlind, 1976).

Data input for the development of the preliminary model include basic geologic information, production scenarios, laboratory tests on rock cores, and the results of well logs and drill-stem tests.

The fidelity of numerical modeling of any geomechanical system will be limited by the quality of input data on configuration and the constitutive relations (material behavior parameters) of the geologic formations and rocks (Thoms, et a1., 1977). The importance of proper constitutive laws cannot be overemphasized--particularly in the case of geologic media. Computer output from any simulation attempt is of no significance unless the material was properly characterized in the first place. Thus the preliminary model must be continually revised as new data become available (Step 2).

Step 3 provides for incorporation of input on actual production into the model (the preliminary model used production scenarios). Once data from the field instrumentation network is obtained and interpreted, the actual behavior of the geopressured system can be determined and monitored (Step 4). In situ monitoring of displacements at depth, if possible, would be particularly helpful here, both as input to the model and in verification of the laboratory tests results. Agreement between the behavior of the system and the preliminary model will then be examined (Step 5). If there is agreement, longer term predictions can be made (Step 6). If not, the model must again be revised (Step 2). Revision and the remaining steps will be required whenever new data become available.

5. Estimated Costs. Estimated costs of implementing this plan are given in Table IV-C-I. 
Table IV-C-1. Estimated costs of performing geological effects studies at a geopressured site 50-60 sq. mi. in area.

\begin{tabular}{|c|c|c|}
\hline Activity & Estimated Costs & Cost Bases \\
\hline $\begin{array}{l}\text { LEVEL I } \\
\text { Precise Leveting }\end{array}$ & $\$ 50,000-60,000$ per site & $\begin{array}{l}\text { Subcontracted; emplace- } \\
\text { ment and first reading } \\
\text { costs only. }\end{array}$ \\
\hline $\begin{array}{l}\text { Integrated tilt- } \\
\text { meter system }\end{array}$ & $\$ 250,000$ per site & $\begin{array}{l}\text { Subcontracted; equipment } \\
\text { and emplacement costs. }\end{array}$ \\
\hline Seismic system & $\$ 150,000$ per site & $\begin{array}{l}\text { Subcontracted; equipment } \\
\text { and emplacement costs } \\
\text { only. }\end{array}$ \\
\hline Well logs & $\$ 32,000$ per wella & $\begin{array}{l}\text { Subcontracted; } 15,000 \mathrm{ft} \\
\text { well; } 3-0 \text { velocity and } \\
\text { gamma ray neutron log; } \\
\text { truck-on-barge operation. }\end{array}$ \\
\hline $\begin{array}{l}\text { Development of } \\
\text { geologic cross } \\
\text { sections }\end{array}$ & $\$ 11,000$ & $\begin{array}{l}\text { Subcontracted; salaries; } \\
\text { data available at low } \\
\text { cost. }\end{array}$ \\
\hline Aerial survey & $\begin{array}{l}\$ 15,000 \text { per site, } \\
\text { per year }\end{array}$ & $\begin{array}{l}\text { Subcontracted; black and } \\
\text { white infrared photo- } \\
\text { graphy. }\end{array}$ \\
\hline $\begin{array}{c}\text { Review of existing } \\
\text { aerial photos }\end{array}$ & $\begin{array}{c}\$ 5,000 \text { per site, } \\
\text { per year }\end{array}$ & $\begin{array}{l}\text { Existing satellite and } \\
\text { other data acquistion } \\
\text { only. }\end{array}$ \\
\hline $\begin{array}{l}\text { LEVEL II } \\
\text { Engineering geology } \\
\text { studies }\end{array}$ & $\$ 80,000$ per site & $\begin{array}{l}\text { Soils sampling and lab- } \\
\text { oratory equipment only. }\end{array}$ \\
\hline $\begin{array}{l}\text { Lab testing of rock } \\
\text { cores }\end{array}$ & $\begin{array}{c}\$ 600,000 \text { per site, } \\
\text { coring } \\
\$ 200,000 \text { per site, } \\
\text { lab studies }\end{array}$ & $\begin{array}{l}\text { Subcontracted, } 3 \text { wells } \\
\text { cored. Including labor- } \\
\text { atory equipment. }\end{array}$ \\
\hline $\begin{array}{l}\text { LEVEL III } \\
\text { Modeling effort }\end{array}$ & $\begin{array}{r}\$ 90,000 \text { per site, salaries } \\
\$ 20,000 \text { per site, computer } \\
\text { time }\end{array}$ & $\begin{array}{l}\text { 1st yr. costs } \\
\text { lst yr. costs }\end{array}$ \\
\hline $\begin{array}{l}\text { Project management } \\
\text { and data analysis }\end{array}$ & $\begin{array}{l}\$ 125,000 \text { per year } \\
\$ 375,000 \text { per year } \\
\$ 300,000 \text { per year }\end{array}$ & $\begin{array}{l}\text { Senior investigators } \\
\text { Assistants } \\
\text { Benefits and overhead }\end{array}$ \\
\hline
\end{tabular}




\section{AIR QUALITY}

A. Rationale

B. Data Requirements and Availability

C. Plan for the Acquisition of Data for the Assessment of Potential Environmental Impacts of Air Quality 

V. AIR QUALITY

D. P. Harrison, R. A. ìuller, and R. Hilding

The purpose of this section is to provide the rationale and plan for the assessment of potential environmental impacts on air quality from geopressured resource development in Louisiana.

\section{A. RATIONALE}

\section{Introduction}

Impacts on air quality from geopressured resource development will vary in extent and significance depending on the type and extent of the activities, and on the geographical location of the activity. Scenarios for geopressured resource development have been described in Section III. It is clear that air quality impacts associated with a variation of the full-scale development scenario--methane production alone, for example, or a testing situation--will vary considerably. Two principal factors account for the geographical variation. First, the meteorological conditions that determine atmospheric dispersion rates and patterns vary somewhat between the coastal region and the inland region in the study area. Secondly, heavy concentrations of industries in several parts of the study area have contributed to high loadings of several pollutants--particulariy sulfur dioxide, oxidants, particulates and hydrocarbons. The plan proposed here is based on a consideration of these factors, as well as the cumulative effects on air quality of the large-scale development of geopressured resources in the study area.

2. Environmental setting

a. General

The climate of the study area is classified as humid subtropical. 
Warm, moist maritime tropical air from the Gulf of Mexico dominates south Louisiana throughout much of the year. But during winter and spring especially, the maritime tropical air is displaced by intrusions of continental polar air. These outbreaks of cold air accur less frequently during autumn and only rarely in summer.

Due to the moderating effects of the Gulf of Mexico, there is a sharp thermal gradient between coastal and inland sites in Louisiana. This gradient is most notable during winter and can be illustrated by studying maps of freeze days. The 1969-70 winter, a relatively cold winter, shows a gradient ranging from 10 freezes near the coast, to more than 40 freezes near Baton Rouge, approximately 80 miles from the open Gulf of Mexico. During 1971-72, the same gradient ranged from no freezes at the coast to 15 near Baton Rouge.

Precipitation is usually associated with the passage of warm and cold fronts. Heavy intensity showers, usually lasting no more than an hour or two, occur within squall lines ahead of cold fronts during winter and spring. General rains of more than 24 hours duration are uncommon. During summer, precipitation often occurs as brief, heavy showers and thunderstorms between late morning and early evening, with each shower covering a very small area. Average annual precipitation over the study area ranges from $138 \mathrm{~cm}$ (55 inches) in the west up to $162 \mathrm{~cm}$ (65 inches) in the east.

Average weather conditions across the study area in an east-west direction tend to be similar. However, an analysis of the frequency and duration of occurrences of synoptic weather types (Muller and Wax, 1977, using a classification system developed by Muller, 1977) shows 
some differences between Lake Charles in the western portion of the study area, and New Orleans in the eastern portion. Figure $V-A-1$ illustrates the comparison between the frequencies of synoptic weather types and percentages of precipitation at both locations. Table V-A-1 lists the synoptic weather types and their characteristics (Muller, 1977).

A variety of tropical disturbances, ranging from weak easterly waves to severe tropical hurricanes, occasionally influence Louisiana during summer and fall. In Muller's system these disturbances are classified as Gulf Tropical Disturbances. The east-west variation in the frequency of this weather type is insignificant.

A further comparison of synoptic weather type properties at Lake Charles and New Orleans suggests that the average properties of each weather type are similar at the western and eastern margins of coastal Louisiana (Muller \& Wax, 1978). This conclusion is particularly useful, because it provides a means for estimation of weather properties at intermediate locations where there are little to no climatological data. It should be noted from figure $V-A-1$ that al though the properties of the weather types at Lake Charles and New Orleans are similar, the frequencies of occurence of the weather types are somewhat different; there is more frontal overrunning (FOR) and less Frontal Gulf Return (FGR) at Lake Charles than at New Orleans on the average.

Further prel iminary analyses suggest strong gradients of synoptic weather type properties in the wetlands near the coast and especially at the coastline (Muller \& Wax, 1978). At 0600 EST in October, 


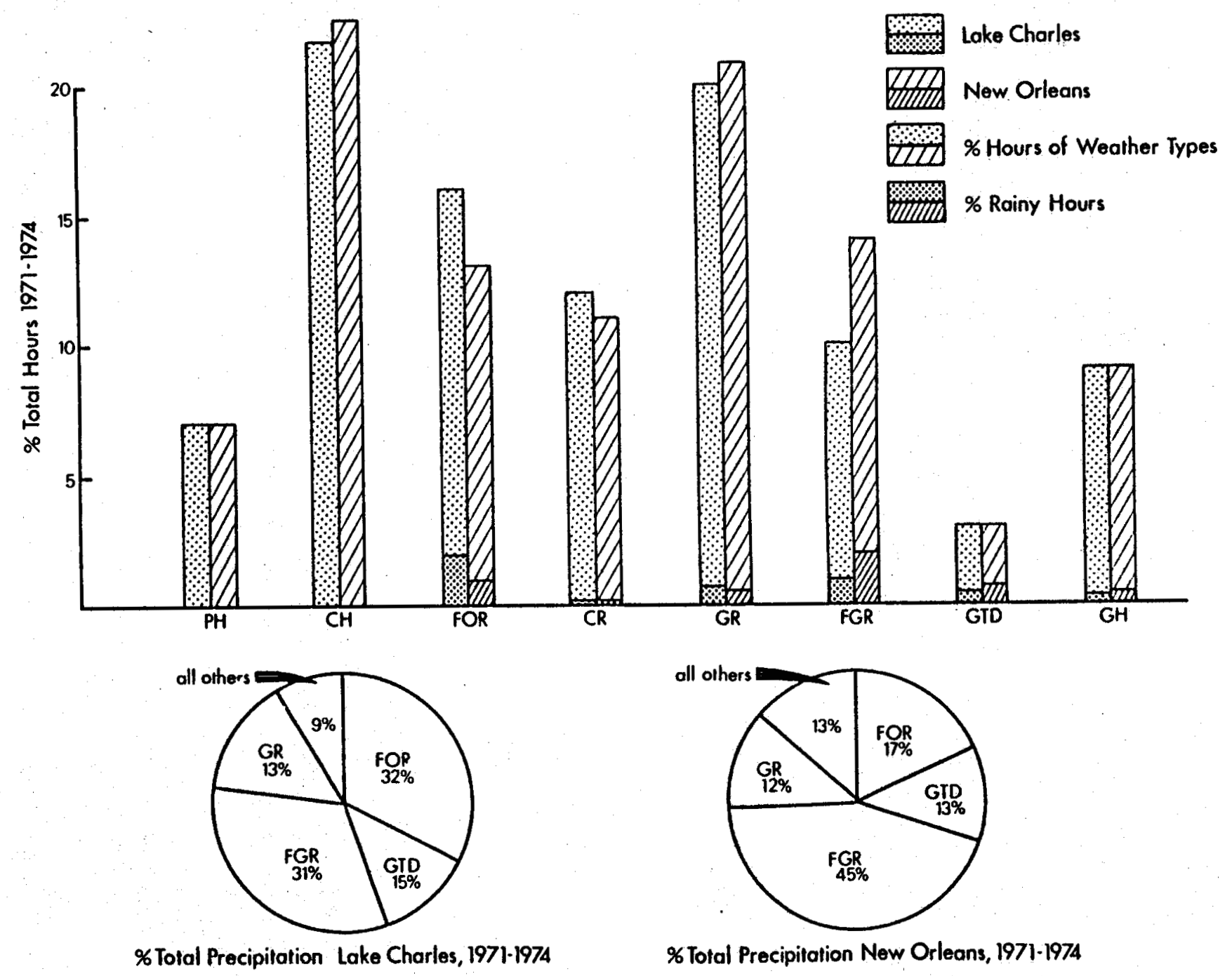

Fig. V-A-1. Mean frequency of synoptic weather types and associated precipitation. (From Muller and Wax, 1977). 
Table V-A-1. Synoptic weather types. (From Muller, 1977).

\begin{tabular}{ll}
\hline Name & Characteristics \\
\hline Pacific High (PH) & $\begin{array}{l}\text { Westerly winds, fair mild weather; rela- } \\
\text { tively poor ventilation at night. }\end{array}$ \\
Continental High (CH) & $\begin{array}{l}\text { Northerly winds, fair and cool to cold } \\
\text { weather; low-level inversions and fair to } \\
\text { poor ventilation at night, especially after } \\
\text { third consecutive day; high-level inver- } \\
\text { sions and intermediate mixing heights } \\
\text { during daytime. }\end{array}$
\end{tabular}

Frontal Overruning (FOR)

Coastal Return (CR)

Gulf Return (GR)

Frontal Gulf Return (FGR)

Gulf Tropical Disturbances (GTD)

Gulf High (GH)
Strong northerly winds with cloudy, cool, temperatures and intermittent precipitation; windy with good horizontal dispersion, but with relatively strong inversion aloft.

Easterly winds, fair weather, cool to mild in winter, hot and humid in summer; highlevel inversions during summer and fall with fair ventilation in the mornings, especially after the third consecutive day.

Brisk southeasterly winds, partly cloudy to mostly cloudy, warm and humid weather; in the morning poor ventilation in winter, fair in summer, excellent ventilation in the afternoons.

Strong and gusty southerly winds, cloudy, warm, and humid weather with showers, thunderstorms, and squall lines; fair to good ventilation in the afternoons.

Includes weak tropical weather systems over the northern Gulf as well as tropical storms and hurricanes-restricted to summer and fallmostly cloudy, warm, windy, and rainy; good to excellent ventilation.

Southwesterly winds, fair and cool to mild weather in winter, hot and humid weather in summer with scattered thundershowers; fair ventilation at night, good ventilation in the afternoons. 
for example, the air temperature at Boothville, located about $96 \mathrm{~km}$ (60 miles) downstream from New Orleans, and nearly surrounded by very warm water from the Mississippi River and the Gulf, averages about $10^{\circ} \mathrm{F}$ warmer than New Orleans during the Continental High (CH) type. During Gulf Return (GR) weather, in contrast, the 0600 CST temperatures are essentially the same at both locations. In January, as an additional example, the average temperature at 0600 CST during the GR type is somewhat lower at Boothville than at New Orleans, probably because Boothville is just about surrounded by very cold water during this season. Hence, the synoptic weather type system permits interpolation of atmospheric properties by synoptic weather types to coastal locations with very limited data.

\section{b. Atmospheric Dispersion Characteristics}

A general description of the atmospheric dispersion characteristics of the coastal zone of Louisiana has been presented by Hsu (1976). He asserts that the ventilation factor, which is the product of the atmospheric mixing height and the wind speed averaged through the mixed layer, is inversely proportional to pollutant concentration. A large ventilation factor, therefore, indicates broad and rapid dispersion of pollutants.

Hsu has also included maps of the mean seasonal and annual mixing heights and wind speeds for coastal Louisiana; these maps are small portions of maps of the United States prepared originally by Hol zworth (1972); the original maps are based on data from 62 locations across the United States. From these maps it is possible to make some 
tentative judgements about ventilation and dispersion characteristics in the Louisiana coastal zone, but the very limited data base must be kept in mind. Perusal of the maps suggests the following generalizations:

1) On the average, ventilation is always greater in the afternoon than in the morning.

2) During the afternoon throughout the year, on the average, ventilation tends to be greater inland, at Baton Rouge for example, than at or near the coastline.

3) During the morning throughout the year, on the average, ventilation tends to be greater at or near the coastline than inland.

4) Inland, in the morning, ventilation tends to be greatest during winter and spring and least during fall.

5) Inland, in the afternoon, ventilation tends to be greatest during spring or fall, and least during winter.

6) Near the coast, in the morning, ventilation tends to be greatest in fall and least during winter and spring.

7) Near the coast, in the afternoon, ventilation tends to be greatest in fall, with the other seasons just slightly less favorable.

8) From Hsu's maps, there are not enough data to judge east to west coastal gradients of ventilation.

The climate and terrain of southern Louisiana have properties which minimize extended and severe periods of air pollution. From a national perspective, the high incidence of deep mixing layers and relatively unstable air contribute to good dispersive qualities (Hol zworth, 1972). In addition, frequent precipitation helps to 
clean the air by washing out suspended particles. In Table V-A-2 the ventilation properties of each of the synoptic weather types have been outlined briefly. These preliminary estimates could be put on a more firm basis by means of an analysis of radiosonde data at Lake Charles and Boothville.

Despite the apparent advantages of the coastal zone for dispersing pollutants, certain mesoscale and microscale phenomena might act to increase pollution concentration in the nearshore region (Hsu, 1976). In particular, with the existence of a well developed sea breeze/land breeze system, pollutants could be trapped within the circulation, which would increase concentrations. Also, the formation of an internal boundary layer within the sea breeze/land breeze circulation, due to aerodynamic roughness changes across the coastline, might increase concentration. However, the apparent general absence of a well developed sea breeze/land breeze in Louisiana and the flat marshy coastal zone, which would dampen the formation of a strong internal boundary layer, probably diminishes the effect of these mesoscale and microscale phenomena.

c. Air Quality Characteristics and Regulations

Ambient air quality standards in Louisiana are summarized in Table V-A-3. The state standards are, with few exceptions, identical to federal air quality standards. There are no state standards for hydrogen sulfide. The Louisiana Air Control Commission (LACC) has the authority to adopt and enforce air quality standards in the state. Parishes and municidalities in Louisiana do not share these dowers.

The LACC operates monitoring stations at selected locations shown in Figure $\mathrm{V}-\mathrm{A}-2$. In addition, local industries operate a 
Table V-A-2. Estimated dispersion characteristics of synoptic weather types.

\begin{tabular}{|c|c|c|c|c|c|c|c|c|}
\hline \multirow{2}{*}{$\frac{0600 \mathrm{CST}}{\mathrm{PH}}$} & \multicolumn{2}{|c|}{$\begin{array}{l}\text { January } \\
\text { (A) (B) }\end{array}$} & \multicolumn{2}{|c|}{$\begin{array}{ll}\text { April }^{\text {(A) }} & \text { (B) }\end{array}$} & \multicolumn{2}{|c|}{ (A) July } & \multicolumn{2}{|c|}{$\begin{array}{l}\text { October } \\
\text { (A) } \quad \text { (B) }\end{array}$} \\
\hline & 2 & 1.5 & 2 & 2.5 & - & - & 2 & 2 \\
\hline $\mathrm{CH}$ & 1.5 & 2.5 & 2 & 2 & 3 & 1.5 & 1.5 & 2 \\
\hline FOR & 2 & 3.5 & 2 & 2.5 & 3 & 2 & 3 & 2.5 \\
\hline$C R$ & 2 & 1.5 & 2 & 1.5 & 2 & 2.5 & 2 & 1.5 \\
\hline$G R$ & 2.5 & 2 & 2.5 & 3 & 3 & 1.5 & 2.5 & 2 \\
\hline FGR & 3 & 3 & 3 & 3 & 3 & 1.5 & 3 & 1.5 \\
\hline$G H$ & 2 & 1.5 & - & - & 2 & 1.5 & 2 & 1 \\
\hline GTD & - & - & - & - & 4 & 1.5 & 4 & 2 \\
\hline
\end{tabular}

\section{CST}

\begin{tabular}{llllllllll}
$\mathrm{PH}$ & 3 & 3 & 3 & 3.5 & - & 3 & 2.5 \\
$\mathrm{CH}$ & 3 & 3.5 & 3 & 4 & 4 & 2.5 & 3 & 2.5 \\
$\mathrm{FOR}$ & 2 & 4 & 2 & 3 & 3 & 2.5 & 3 & 3 \\
$\mathrm{CR}$ & 3 & 3 & 3 & 3.5 & 4 & 3.5 & 3 & 3 \\
$\mathrm{GR}$ & 5 & 4 & 5 & 5 & 5 & 2.5 & 5 & 3.5 \\
$\mathrm{FGR}$ & 5 & 3.5 & 5 & 4 & 5 & 2 & 5 & 3.5 \\
$\mathrm{GH}$ & 3 & 3 & - & - & 4 & 3.5 & 3 & 2.5 \\
GTD & - & - & - & - & 5 & 2.5 & 5 & 2 \\
\hline
\end{tabular}

(A) Index of vertical mixing helghts over land by synoptic weather types. Scale: from 1 to 5 ; with 5 representing deepest mixing layer, and 1 , shallowest mixing layer.

(B) Index of horizontal dispersion based on average wind speeds at Moisant Airport, New Orleans by synoptic weather types. Scale: from 1 to 5 ; with 1 representing weakest, and 5 , strongest.

- No occurrences of weather types during the month. 
Table V-A-3. Ambient air quality standards: State of Louisiana. (From LACC,

Pollutant

Sulfur Dioxide

Annual Arithmetic Mean

24-Hour Maximum

3-Hour Maximum

Carbon Monoxide

8-Hour Maximum

1-Hour Maximum

Ozone (Oxidant)

Annua 7 Arithmetic Mean

1-Hour Maximum

Nitrogen Dioxide

Annual Arithmetic Mean

Total Suspended Particulate Annual Geometric Mean

24-Hour Maximum
Primary

$$
\begin{gathered}
80 \mu \mathrm{g} / \mathrm{m}^{3} \\
365 \mu \mathrm{g} / \mathrm{m}^{3} \\
-\cdots
\end{gathered}
$$

$10 \mathrm{mg} / \mathrm{m}^{3}$

$40 \mathrm{mg} / \mathrm{m}^{3}$

$58.8 \mu \mathrm{g} / \mathrm{m}^{3}$

$160 \mu \mathrm{g} / \mathrm{m}^{3}$

$100 \mu \mathrm{g} / \mathrm{m}^{3}$

$75 \mu \mathrm{g} / \mathrm{m}^{3}$

$260 \mu \mathrm{g} / \mathrm{m}^{3}$
Secondary

$$
\begin{array}{r}
60 \mu \mathrm{g} / \mathrm{m}^{3} \\
260 \mu \mathrm{g} / \mathrm{m}^{3} \\
1300 \mu \mathrm{g} / \mathrm{m}^{3}
\end{array}
$$

$10 \mathrm{mg} / \mathrm{m}^{3}$
$40 \mathrm{mg} / \mathrm{m}^{3}$

$58.8 \mu \mathrm{g} / \mathrm{m}^{3}$

$160 . \mu \mathrm{g} / \mathrm{m}^{3}$

$100, \mathrm{ug} / \mathrm{m}^{3}$

$60 \mathrm{ug} / \mathrm{m}^{3}$

$150, \mathrm{ug} / \mathrm{m}^{3}$ 


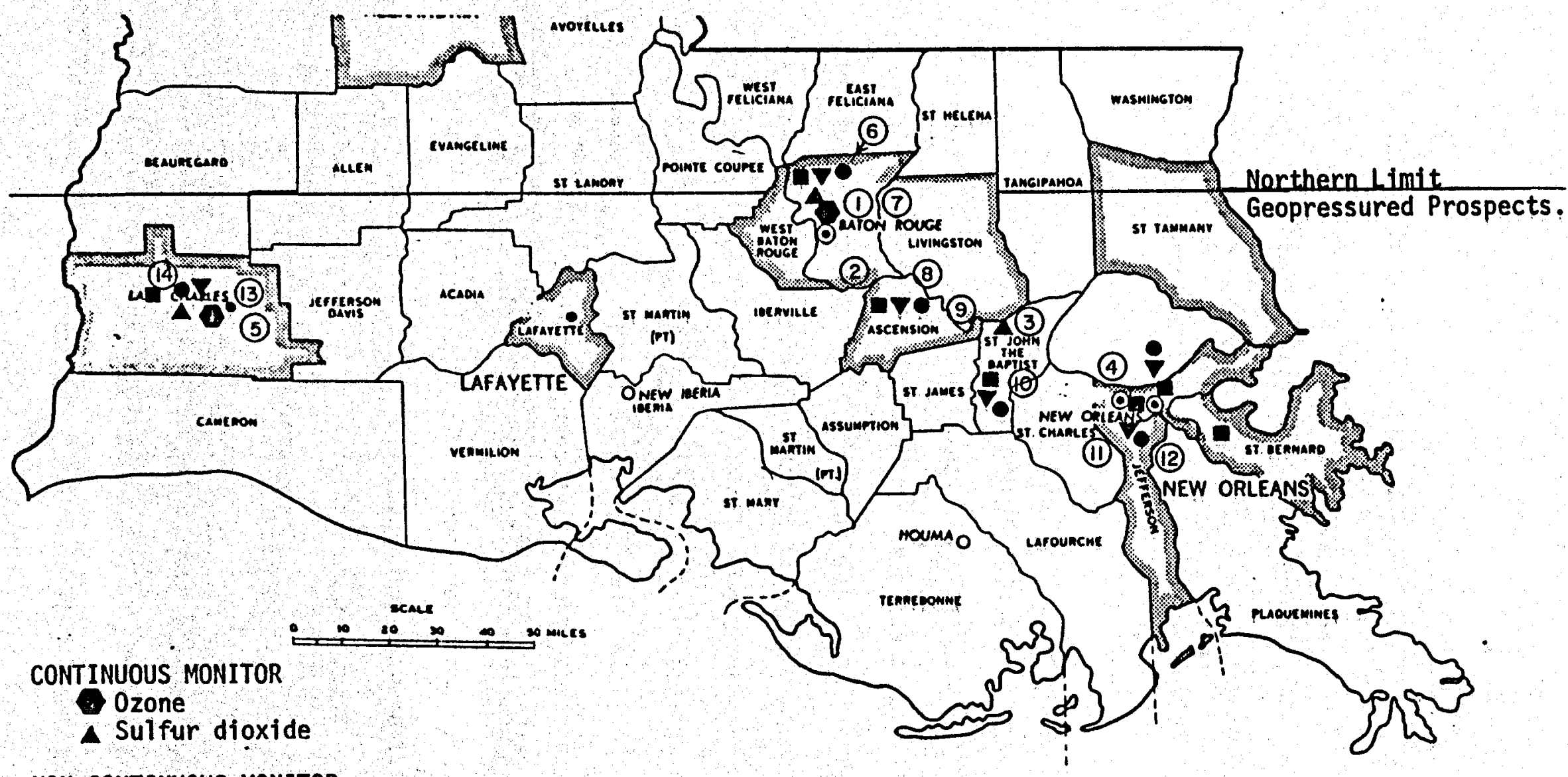

NON-CONTINUOUS MONITOR

- Total suspended particulate

$\checkmark$ Sulfur dioxide

- Nitrogen dioxide

Fig. V-A-2. Louisiana Air Control Commission monitoring stations.

(1)-(14) Station locations:

see Tables $V-A-4$ and $V-A-5$

Metropolitan areas 
relatively large number of stations and report their data to the LACC. Almost without exception, both the LACC and industrial monitoring stations are located near the highly industrialized areas along the Mississippi River from Baton Rouge to New Orleans and in the Lake Charles area of Calcasieu Parish. Ambient air data from LACC monitoring stations in these areas are summarized in Tables $\mathrm{V}-\mathrm{A}-4$ and V-A-5. A full description of the sampling and analysis techniques used may be found in the LACC Ambient Air Data Report (LACC, 1976). On the basis of these data, this region of Louisiana has been defined a non-compliance area only with respect to orone. Indeed, violations of the one hour ozone standard occur at all ozone monitoring stations. Geopressured energy development is not expected to contribute significantly to the ozone loadings either as a result of direct ozone emissions or indirectly by the emission of oxidant precursors. Although the south Louisiana area is in compliance with particulate and sulfur oxide standards, there is concern over future levels of these pollutants in the industrialized areas (Coerver, personal communication, 1977). Continued industrial expansion coupled with inevitable substitution of liquid and solid fuels for natural gas will both contribute to higher particulate and sulfur oxide emissions. The level of hydrocarbon emissions in south Louisiana is of real concern because of its contribution to photochemical smog. However, emissions of reactive hydrocarbons and particulates associated with geopressured resource development are expected to be minimal. Potential emissions of hydrogen sulfide are of prime concern from geopressure sources. Because of its high toxicity and low odor threshold, 
Table V-A-4. Summary of ambient air quality data 1976. (Continuous monitoring sites).

\begin{tabular}{|c|c|c|c|c|c|}
\hline \multirow[b]{2}{*}{$\begin{array}{l}\text { Map } \\
\text { No.* }\end{array}$} & \multirow[b]{2}{*}{ Location } & \multicolumn{2}{|c|}{ Ozone, $\mu \mathrm{g} / \mathrm{m}^{3}$} & \multicolumn{2}{|c|}{ Sulfur Dioxide, $\mu g /$} \\
\hline & & $\begin{array}{l}\text { Annuat } \\
\text { Arith. } \\
\text { Mean }\end{array}$ & $\begin{array}{r}\text { Max. } \\
\text { 1-Hour } \\
\text { Conc. }\end{array}$ & $\begin{array}{l}\text { Annual } \\
\text { Arith. } \\
\text { Mean }\end{array}$ & $\begin{array}{l}\text { Max. } \\
\text { 1-Hour } \\
\text { Conc. }\end{array}$ \\
\hline 1 & Baton Rouge (LSU) & 54.9 & 394 & 44.5 & 162 \\
\hline 2 & Carville & 49 & 325 & -- & $\cdots$ \\
\hline 3 & Garyville & $-\infty$ & -- & 13.1 & 105 \\
\hline 4 & $\begin{array}{l}\text { New Orleans } \\
\text { (State Office Bldg.) }\end{array}$ & 31.4 & 231 & $-\infty$ & -- \\
\hline 5 & $\begin{array}{l}\text { Lake Charles } \\
\text { (Health Unit) }\end{array}$ & 49 & 282 & 26.2 & 223 \\
\hline
\end{tabular}

* Location numbers, Figure V-A-2. 
Table V-A-5. Summary of ambient air quality data, 1976. (Non-continuous monitoring sites).

\begin{tabular}{|c|c|c|c|c|c|c|c|}
\hline \multirow[b]{2}{*}{$\begin{array}{l}\text { Map } \\
\text { No.* }\end{array}$} & \multirow[b]{2}{*}{ Location } & \multicolumn{2}{|c|}{$\begin{array}{l}\text { Total Suspended } \\
\text { Particulates, } \mu \mathrm{g} / \mathrm{m}^{3}\end{array}$} & \multicolumn{2}{|c|}{$\begin{array}{c}\text { Sulfur Dioxide } \\
\mu \mu \mathrm{g} / \mathrm{m}^{3}\end{array}$} & \multicolumn{2}{|c|}{$\underset{\mu \mathrm{g} / \mathrm{m}^{3}}{\text { Nitroxide }}$} \\
\hline & & $\begin{array}{l}\text { Annual } \\
\text { Geometric } \\
\text { Mean }\end{array}$ & $\begin{array}{l}\text { Max. } \\
\text { 24-Hour } \\
\text { Conc. }\end{array}$ & $\begin{array}{l}\text { Annual } \\
\text { Arith. } \\
\text { Mean }\end{array}$ & $\begin{array}{l}\text { Max. } \\
\text { 24-Hour } \\
\text { Conc. }\end{array}$ & $\begin{array}{l}\text { Annual } \\
\text { Arith. } \\
\text { Mean } \\
\end{array}$ & $\begin{array}{l}\text { Max. } \\
\text { 24-Hour } \\
\text { Conc. }\end{array}$ \\
\hline $\begin{array}{l}6 \\
7 \\
8 \\
9 \\
10 \\
11 \\
12\end{array}$ & $\begin{array}{l}\text { Baton Rouge } \\
\text { Evangeline } \\
\text { LSU } \\
\text { Carville } \\
\text { Geismar } \\
\text { Garyville } \\
\text { Harvey } \\
\text { New Orleans }\end{array}$ & $\begin{array}{l}54 \\
47 \\
37 \\
35 \\
43 \\
62\end{array}$ & $\begin{array}{r}109 \\
155 \\
92 \\
46 \\
100 \\
121\end{array}$ & $\begin{array}{l}27.1 \\
1.9 \\
2.5 \\
1.6 \\
1.9 \\
1.3\end{array}$ & $\begin{array}{r}162 \\
20 \\
14 \\
6 \\
16 \\
6\end{array}$ & $\begin{array}{l}51.1 \\
37.2 \\
17.4 \\
26.8 \\
18.5 \\
47.1\end{array}$ & $\begin{array}{r}102 \\
74 \\
49 \\
61 \\
73 \\
111\end{array}$ \\
\hline & $\begin{array}{l}\text { Algiers Pump Sta. } \\
\text { Civil Court Bldg. } \\
\text { Fire Station } 5 \\
\text { Pumping Station } 3 \\
\text { Pumping Station } 4 \\
\text { Water Purification Plant } \\
\text { Woodland Place }\end{array}$ & $\begin{array}{l}40 \\
62 \\
37 \\
60 \\
40 \\
67 \\
57\end{array}$ & $\begin{array}{r}68 \\
119 \\
90 \\
176 \\
97 \\
126 \\
126\end{array}$ & $\begin{array}{l}--- \\
1.3 \\
--- \\
--- \\
--- \\
---\end{array}$ & $\begin{array}{c}\cdots \\
\cdots \\
\cdots- \\
\cdots- \\
\cdots- \\
\cdots-\end{array}$ & $\begin{array}{l}--- \\
19.4 \\
--- \\
-- \\
--- \\
---\end{array}$ & $\begin{array}{c}--- \\
48 \\
--- \\
--- \\
--- \\
--\end{array}$ \\
\hline 13 & $\begin{array}{l}\text { Lake Charles } \\
\text { Health Unit } \\
\text { McNeese } \\
\text { Westlake }\end{array}$ & $\begin{array}{l}55 \\
42 \\
49\end{array}$ & $\begin{array}{l}154 \\
117 \\
136\end{array}$ & $\begin{array}{l}1.5 \\
1.7 \\
1.5\end{array}$ & $\begin{array}{r}13 \\
19 \\
9\end{array}$ & $\begin{array}{l}42.7 \\
25.3 \\
30.9\end{array}$ & $\begin{array}{l}77 \\
53 \\
50\end{array}$ \\
\hline
\end{tabular}

*Location numbers, Figure $\mathrm{V}-\mathrm{A}-2$. 
tight controls will be necessary. Therefore, geopressured resource development is not expected to contribute significantly to ambient sulfur oxide concentrations. The atmospheric emissions subject is covered in more detail in Section $\mathrm{V}-\mathrm{A}-3$.

The areas for which reasonably complete ambient air data are available lie, in general, on the edges of the potential geopressured development area. Most of the geopressured prospect sites are in rural areas relatively far removed from industrial development. No permanent air monitoring stations exist in these areas and only very limited data are available as a result of special studies. As a result of a fairly exhaustive search, three special ambient air studies having direct application to the geopressured prospect area have been located. Two industrial studies performed by Cabot Corporation in St. Mary Parish and by Ashland Chemical Company in Iberia Parish at the request of the Louisiana Air Control Commision do provide limited background $\mathrm{SO}_{2}$ data. In addition, Radian Corporation conducted a more complete three month air monitoring program at nine locations under the sponsorship of the Environmental Protection Agency Region VI office in Dallas. Figure $V-A-3$ shows the locations of these special studies. Cabot Corporation operates a carbon black plant in St. Mary Parish near the town of Franklin, Louisiana approximately $88 \mathrm{~km}$ ( 55 miles) south-southwest of Baton Rouge. As a provision in their emissions permit, the LACC required Cabot to undertake a rather extensive $\mathrm{SO}_{2}$ ambient air monitoring program extending approximately from March 1976 through July 1977. Both 3-hour maximum and 24-hour average concentrations were monitored. On only one occasion, May 27, 1976, was the 24-hour secondary standard of $260 \mu \mathrm{g} / \mathrm{m}^{3}$ exceeded. The three 
hour maximum secondary standard of $1300 \mathrm{ug} / \mathrm{m}^{3}$ was closely approached on both May 27 and May 28, 1976 but never exceeded. Cabot officials attribute the abnormally high concentrations during this period to a barge collision on the Gulf Intracoastal Waterway very near the ambient air monitor. During normal conditions, the maximum concentrations noted were approximately $70 \%$ of the secondary standards with the majority of the individual readings showing less than $20 \%$ of the standard (Beck, personal communication, 1977).

The Ashland Chemical Company was required by the LACC to monitor ambient $\mathrm{SO}_{2}$ levels during 1975 and 1976 near their carbon black facility in Iberia Parish near New Iberia, Louisiana. Only 24-hour average values were reported. The single highest value of $115 \mathrm{ug} / \mathrm{m}^{3}$, was approximately $32 \%$ of the primary standard and $45 \%$ of the secondary. The second highest value was $61 \mathrm{ug} / \mathrm{m}^{3}$ while most daily readings were below $20 \mathrm{ug} / \mathrm{m}^{3}$ (Minott, personal communication, 1978).

The final source of ambient air background data was obtained from monitoring work carried on by Radian Corporation at nine south Louisiana locations during 1976. This work was sponsored by Region VI of the Environmental Protection Agency. Nitrogen oxides $\left(\mathrm{NO}_{x}\right)$, nitric oxide (NO), nitrogen dioxide $\left(\mathrm{NO}_{2}\right)$, sulfur dioxide $\left(\mathrm{SO}_{2}\right)$, ozone, and particulates were monitored along with key meteorological parameters such as wind speed, wind direction relative humidity, precipitation and solar insolation (Radian Corp., 1977). The location of the nine stations is shown in Figure $\mathrm{V}-\mathrm{A}-3$ and selected data is presented in 


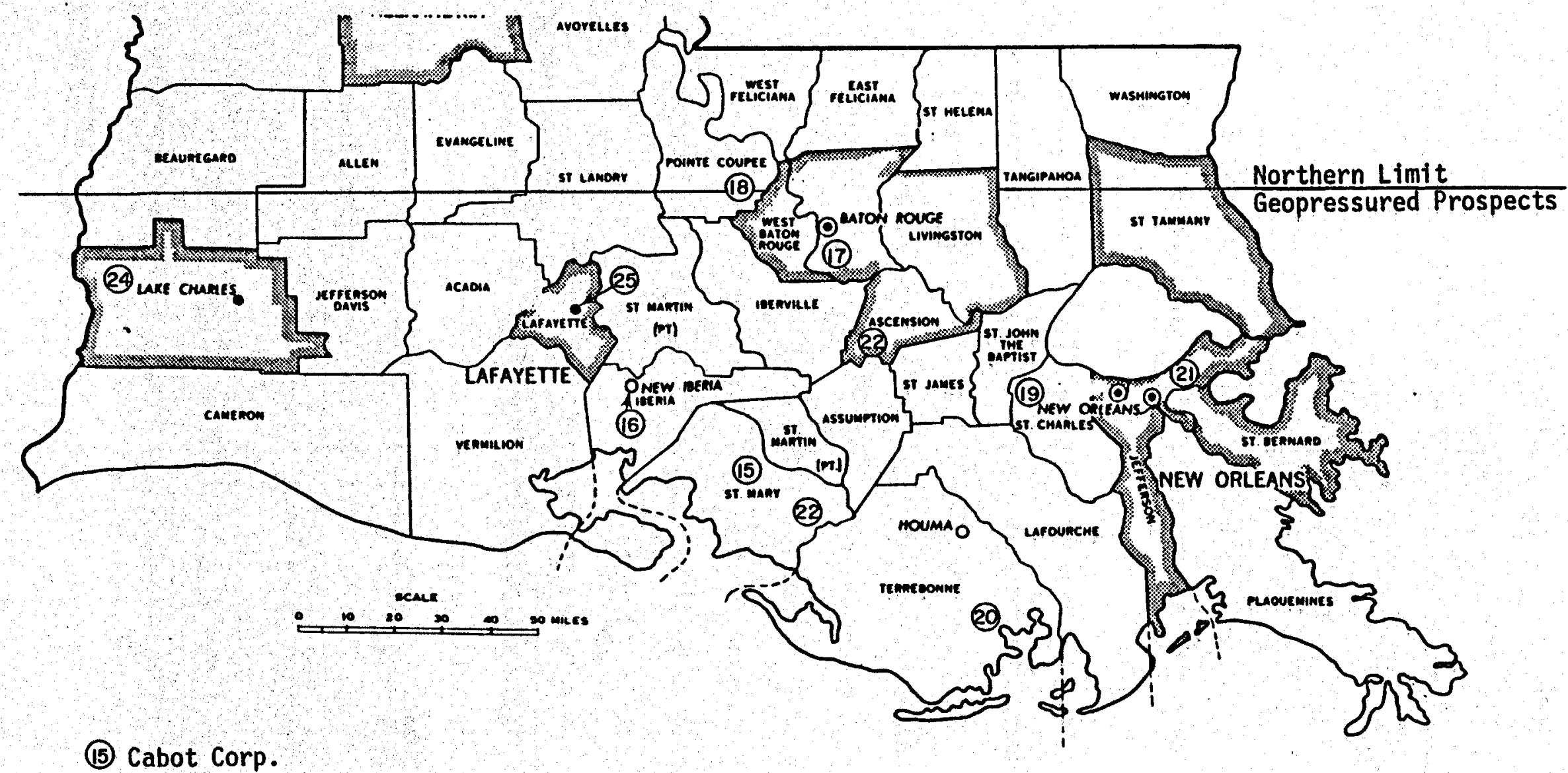

(16) Ashland Chemical co,

(17)-(24) Radian Corp. See Table V-A-6 Fig. V-A-3. Locations of special
air quality studies. 
Table V-A-6. While this data is limited in duration it does reinforce the concern previously expressed with respect to ozone loadings, and to a lesser degree, particulate loadings.

\section{Potential Environmental Impacts}

Potential impacts on ambient air quality from geopressured resource development in the study area are discussed below. The identification of these potential impacts and their relative significance in the study area is based on the description of the proposed activity and resource characterization (see Section III) in view of the environmental setting of the study area, as described above. In addition, interviews with representatives of regulatory agencies, research and planning groups, and industries were used to identify impacts and assess their relative significance.

In general, impacts on air quality from development of the resource are expected to be minor and localized. The significance of air quality impacts relative to potential impacts on ecosystem and water quality and relative to the effects of subsidence, is considered by the LSU investigators to be very low.

This assessment could change as new data become available on the chemical properties of the geopressured fluids. As discussed in detail in Section III, we must consider the physical characteristics of the geopressured fluids to be largely unknown at this time. Because much of the data currently available was originally collected for other purposes, it cannot be used with confidence in the assessment of air quality impacts. However, control technology exists and 
Table V-A-6. Average concentrations $\left(\mathrm{mg} / \mathrm{m}^{3}\right)$ of se ected pollutants in south Louisiana. (From Radian Corporation, 1977).

\begin{tabular}{|c|c|c|c|c|c|c|}
\hline $\operatorname{lap}_{0 . *}$ & Site & Pollutant & $\begin{array}{l}\text { July 17- } \\
\text { July } 31,1976\end{array}$ & $\begin{array}{l}\text { Aug. } 1- \\
\text { Aug. } 31, \quad 1976\end{array}$ & $\begin{array}{l}\text { Sept. } 1- \\
\text { Sept. } 30,1976\end{array}$ & $\begin{array}{l}\text { Oct. } 1- \\
\text { Oct. } 17,1976\end{array}$ \\
\hline 7 & St. Gabriel & $\begin{array}{l}\text { Nitrogen oxides } \\
\text { Nitric Oxide } \\
\text { Nitrogen Dioxide } \\
\text { Sulfur Dioxide } \\
\text { Ozone } \\
\text { Particulate }\end{array}$ & & $\begin{array}{l}8.7 \\
3.1 \\
5.6 \\
87.3 \\
55.5\end{array}$ & $\begin{array}{r}8.6 \\
1.3 \\
4.2 \\
.0 \\
78.6 \\
44.3\end{array}$ & $\begin{array}{r}19.6 \\
3.6 \\
15.6 \\
.0 \\
100.4 \\
50.3\end{array}$ \\
\hline 8 & St. Alma & $\begin{array}{l}\text { Nitrogen oxides } \\
\text { Nitric Oxide } \\
\text { Nitrogen Dioxide } \\
\text { Sulfur Dioxide } \\
\text { Ozone } \\
\text { Particulate }\end{array}$ & $\begin{array}{l}3.6 \\
0.3 \\
3.3 \\
0.1\end{array}$ & $\begin{array}{l}2.9 \\
0.6 \\
2.2 \\
0.2 \\
69.7 \\
46.3\end{array}$ & $\begin{array}{r}5.4 \\
1.2 \\
4.2 \\
0.5 \\
58.5 \\
41.3\end{array}$ & $\begin{array}{r}5.4 \\
1.0 \\
4.5 \\
3.4 \\
66.2 \\
38.2\end{array}$ \\
\hline 19 & Norco & $\begin{array}{l}\text { Nitrogen Oxides } \\
\text { Nitric Oxide } \\
\text { Nitrogen Dioxide } \\
\text { Sulfur Dioxide } \\
\text { Ozone } \\
\text { Particulate }\end{array}$ & $\begin{array}{r}21.5 \\
9.6 \\
15.6 \\
53.7\end{array}$ & $\begin{array}{r}29.1 \\
6.3 \\
24.0 \\
9.6 \\
60.8 \\
69.1\end{array}$ & $\begin{array}{r}23.2 \\
8.1 \\
15.7 \\
3.5 \\
54.4 \\
63.9\end{array}$ & $\begin{array}{r}40.7 \\
17.5 \\
19.9 \\
6.6 \\
85.3\end{array}$ \\
\hline$? 0$ & Galliano & $\begin{array}{l}\text { Nitrogen Oxides } \\
\text { Nitric 0xide } \\
\text { Nitrogen Dioxide } \\
\text { Sulfur Dioxide } \\
\text { Ozone } \\
\text { Particulate }\end{array}$ & $\begin{array}{l}10.0 \\
2.4 \\
7.6 \\
2.3\end{array}$ & $\begin{array}{l}5.6 \\
2.4 \\
3.1 \\
1.0 \\
42.5\end{array}$ & $\begin{array}{r}5.7 \\
2.0 \\
3.8 \\
0.4 \\
84.3\end{array}$ & $\begin{array}{l}78.0 \\
41.3\end{array}$ \\
\hline 21 & NASA & $\begin{array}{l}\text { Nitrogen Oxides } \\
\text { Nitric Oxide } \\
\text { Nitrogen Dioxide } \\
\text { Sulfur Dioxide }\end{array}$ & $\begin{array}{r}31.9 \\
7.5 \\
24.4 \\
1.2\end{array}$ & $\begin{array}{r}16.1 \\
5.8 \\
11.0 \\
3.5\end{array}$ & $\begin{array}{r}15.9 \\
4.7 \\
11.2 \\
2.6\end{array}$ & $\begin{array}{r}31.2 \\
8.9 \\
22.3 \\
4.4\end{array}$ \\
\hline
\end{tabular}


Table $V-A-6$, continued.

$\begin{array}{lllll}\text { Map Site } & \text { Pollutant } & \text { July 17- } & \text { Aug. 1- } & \text { Sept. 1- } \\ \text { No.* } & \text { July 31, 1976 } & \text { Aug. 31, 1976 } & \text { Sept. 30, 1976 } & \text { Oct. 1- 17, 1976 }\end{array}$

\begin{tabular}{|c|c|c|c|c|c|c|}
\hline & & $\begin{array}{l}\text { Ozone } \\
\text { Particulate }\end{array}$ & 70.5 & $\begin{array}{l}76.0 \\
58.7\end{array}$ & $\begin{array}{l}88.7 \\
59.5\end{array}$ & 45.7 \\
\hline 22 & Morgan City & $\begin{array}{l}\text { Nitrogen Oxides } \\
\text { Nitric Oxide } \\
\text { Nitrogen Dioxide } \\
\text { Sulfur Dioxide } \\
\text { Ozone } \\
\text { Particulate }\end{array}$ & $\begin{array}{r}7.0 \\
4.5 \\
2.6 \\
78.0\end{array}$ & $\begin{array}{r}11.5 \\
5.0 \\
6.6 \\
4.0 \\
77.1 \\
65.1\end{array}$ & $\begin{array}{r}0.7 \\
71.7\end{array}$ & $\begin{array}{l}95.3 \\
82.4\end{array}$ \\
\hline 23 & St. James & $\begin{array}{l}\text { Nitrogen Oxides } \\
\text { Nitric Oxide } \\
\text { Nitrogen Dioxide } \\
\text { Sulfur Dioxide } \\
\text { Ozone } \\
\text { Particulate }\end{array}$ & 57.4 & $\begin{array}{l}30.6 \\
11.8 \\
18.8\end{array}$ & $\begin{array}{l}29.1 \\
12.2 \\
16.8 \\
69.6 \\
76.7\end{array}$ & $\begin{array}{l}20.1 \\
20.2 \\
84.7 \\
82.9\end{array}$ \\
\hline 24 & Vinton & $\begin{array}{l}\text { Nitrogen Oxides } \\
\text { Nitric Oxide } \\
\text { Nitrogen Dioxide } \\
\text { Sulfur Dioxide } \\
\text { Ozone } \\
\text { Particulate }\end{array}$ & $\begin{array}{r}19.6 \\
6.5 \\
13.1 \\
1.3 \\
53.1 \\
42.4\end{array}$ & $\begin{array}{r}16.5 \\
5.4 \\
11.1 \\
46.8\end{array}$ & $\begin{array}{r}12.2 \\
2.4 \\
9.9 \\
0.7 \\
60.0 \\
43.5\end{array}$ & $\begin{array}{r}22.3 \\
5.9 \\
16.3 \\
0.9 \\
73.9 \\
41.5\end{array}$ \\
\hline 25 & Lafayette & $\begin{array}{l}\text { Nitrogen Oxides } \\
\text { Nitric Oxide } \\
\text { Nitrogen Dioxide } \\
\text { Sulfur Dioxide } \\
\text { Ozone } \\
\text { Particulate }\end{array}$ & $\begin{array}{r}10.6 \\
3.2 \\
7.4 \\
0.3 \\
69.7 \\
47.5\end{array}$ & $\begin{array}{r}9.1 \\
3.9 \\
5.1 \\
2.1 \\
95.1 \\
56.9\end{array}$ & $\begin{array}{r}10.6 \\
4.6 \\
5.9 \\
0.7 \\
71.7 \\
45.2\end{array}$ & $\begin{array}{l}75.5 \\
59.6\end{array}$ \\
\hline
\end{tabular}

* Location numbers, Figure V-A-3. 
can effectively ameliorate problems associated with atmospheric emissions during normal operation of geopressured wellfields and plants.

Large-scale development of geopressured resources in the study area is not expected to have a serious cumulative impact on air quality. Many of the prospect areas are in rural settings relatively far removed from industrial levelopment. Energy plants will be small and scattered. A wellfield $130-160 \mathrm{~km}^{2}\left(50-60 \mathrm{mi}^{2}\right)$ in extent will support an eneray plant with a generating capacity of $25 \mathrm{MW}$. Only when the addition of geopressured power plants add pollutants in areas with high pollutant loadings, will significant air quality impacts arise. Two areas within the study region contain both geopressured prospects and industrial concentrations--the Lake Charles area and the Baton Rouge-New Orleans corridor. The special problems of these areas are discussed in Section V-A-2.

Impacts of concern in terms of air quality are discussed below. It should be noted that impacts from activities ancillary to resource recovery--i.e, industrialization, residential and commercial activity-are beyond the scope of this study.

\section{a. Site Preparation and Construction}

Air quality degradation caused by site preparation and construction activities should be both minimal and localized. Particulate levels may be increased near sites where extensive grading, leveling, and filling is required. Localized noise problems associated with operation of heavy equipment, both during site preparation, plant construction and well drilling may materialize. Emissions from 
internal combustion engines used during site preparation, well drilling and construction of the energy plant should not add significantly to ambient pollutant levels.

\section{b. Wellfield and Plant Operation}

Adverse impacts on air quality during normal operating conditions are expected to be minor and localized. A detailed discussion of the type and extent of emissions associated with each major processing step in the gas separation and power generation operations has been presented by Wilson, et al. (1977).

Steam plumes from wet cooling towers will be the most obvious atmospheric emission from the facility. This emission can, under certain atmospheric conditions (at night, especially when the FOR, CR, GR, and FGR weather types are in effect), cause localized fogging. The problem is expected to be relatively minor and quite similar to cooling tower emissions from many other industrial sources in the study area. The relatively small size of the power plant will tend to limit the adverse effects to a relatively small area. The actual emission will be air and entrained water droplets. The water droplets will contain relatively high TDS levels and small amounts of any chemicals used as corrosion inhibitors or fungicides, which would be harmful to vegetation in the area of contact (Wilson, et. al., 1977).

Atmospheric hydrogen sulfide emissions are of major concern in many of the world's geothermal resource areas. The very low odor threshold makes even small amounts of $\mathrm{H}_{2} \mathrm{~S}$ immediately evident. As previously discussed, the $\mathrm{H}_{2} \mathrm{~S}$ levels in geopressured fluids must, 
at present, be treated as an unknown. If the flutds are free of $\mathrm{H}_{2} \mathrm{~S}$, then there is no potential for air emissions. If appreciable $\mathrm{H}_{2} \mathrm{~S}$ levels are found, then control technology must be included as an integral portion of the gas separation/power generation plant. Processes for the removal of $\mathrm{H}_{2} \mathrm{~S}$ and recovery of elemental sulfur are commercially available. Both the natural gas and petroleum refining industries operate processes capable of recovering $99.9 \%$ of the feed sulphur. If a problem does materialize, it can be controlled during normal operation sufficiently to meet standards. While neither federal nor Louisiana ambient air standards have been set for $\mathrm{H}_{2} \mathrm{~S}$, such standards are likely to be promulgated in the near future--certainly on the federal level. California has established a one-hour hydrogen sulfide standard of $42 \mathrm{ug} / \mathrm{m}^{3}$. In addition, Texas has defined a 30 -minute net downwind concentration standard of $0.08 \mathrm{ppm}$ in residential, business, and commercial areas and $0.12 \mathrm{ppm}$ in other areas. The net downwind concentration is defined as the downwind concentration minus the upwind concentration (Texas Water Quality Board Standard, Regulation II, Rule 203).

Localized noise problèms may also occur during normal plant operation. Fans, motors, pumps and compressors are all noise generators and may cause local nuisance problems. Considerable noise may be expected from the high pressure vapor-liquid separation units. Noise abatement equipment may be required to ameliorate these probłems. Again, noise problems of the magnitude and type anticipated in geopressured development are expected to be quite similar to those encountered in many of the area's industries. 
The overall degradation of air quality during normal operating conditions is expected to be both small and localized. This assumes, of course; that control technology will be included for $\mathrm{H}_{2} \mathrm{~S}$ if necessary.

\section{c. Accidental Occurrences}

Atmospheric emissions associated with major accidents, either in the geopressured well field or the gas separation/power plant, can be much more severe than during normal operating conditions. Such a statement is true for many of the region's industrial activities.

Accidental occurrences can never be completely elfminated, a) though proper design and maintenance practices can minimize both the frequency of occurrence and the adverse impact associated with the event. A major accident could result in the direct discharge into the environment of large volumes of high pressure, hot water. Air quality impacts would be largely those previously mentioned-fog, hydrogen sulfide, and noise, although in potentially much greater quantity. 


\section{B. DATA REQUIREMENTS AND AVAILABILITY}

\section{Data Requirements}

Data requirements for the long-term assessment of potential impacts on air quality are summarized in Table V-B-1. The air pollutants to be measured both before and after development activities begin include those likely to be emitted in significant quantities from a geopressure operation; i.e., hydrogen sulfide, ammonia, and carbon dioxide; those likely to be involved in the transformation of $\mathrm{H}_{2} \mathrm{~S}$ to $\mathrm{SO}_{2}$, i.e., ozone and particulates; and those for which ambient air quality standards have been established.

Commercial instruments are avallable to provide for continuous monitoring of each of the gaseous pollutants. Particulate sampling should be conducted on a frequent periodic basis. Selected particulate samples should be collected, returned to the laboratory, and subjected to detajled elemental and sulfate analysis as well as particle size distribution.

Radiological monitoring is thought necessary strictly as a precaution. As previously discussed (Section III-C), radiological analysis of fluids from the Delcambre well revealed radon concentration above expected background levels. If additional geopressured fluid testing confirms significant levels of radioactivity, this phase of the monitoring will need considerable expansion. On the other hand, if fluid radioactivity levels are found to be low, this phase may be terminated once the background levels are measured.

Meteorological and source emission data should be utilized in appropriate dispersion models to predict the impact which may 
Table V-B-1. Data required for assessment of impacts on air quality.

Pollutants

* Sulfur Dioxide Hydrogen Sulfide

Total Sulfur

*Ozone

Ammonia

*Nitrogen Oxides $\left(\mathrm{NO}_{*}, \mathrm{NO}_{2}, \mathrm{NO}\right)$

* Carbon Dioxide

* Total Particulate

*Hydrocarbons

Radiological

Gross Alpha

Gross Beta

Radon

Meteorological

Wind Direction

Wind Speed

Precipitation

Relative Humidity

Solar Radiation

*Air quiaity standards are in effect for these pollutants. 
result from various scenarios associated with long-term geopressured energy development, and at specific sites. A variety of computer models to accomplish this purpose have been developed. A brief description of one set of such models developed by the Environmental Protection Agency is provided below.

\section{1) Climatological Dispersion Model (CDM). Determines long} term (seasonal or annual) quasi-stable pollutant concentrations at any ground-level receptor using average emission rates from point and area sources and a joint frequency distribution of wind direction, wind speed, and stability for the same period (EPA, 1973).

2) PTMAX. An interactive program which performs an analysis of the maximum, short-term concentration from a point source as a function of stability and wind speed (Turner and Busse, 1973).

3) PTDIS. An interactive program which computes short-term concentrations downwind from a point source at distance specified by the user (Turner and Busse, 1973).

4) PTMTP. An interactive program which computes, at multiple receptors, short-term concentrations resulting from multiple point sources (Turner and Busse, 1973).

It is important to note that this set of programs has proven to be quite reliable in other Louisiana studies (Fielder and Harrison, 1977). The level terrain and the relatively straight wind patterns are thought to be an important reason for the apparent reliability.

The more general meteorological characteristics listed in Table $V-B-1$, as well as an historical record of pollution episodes 
and emission inventory, will provide data for mesoscale studies to assess air pollution dispersion potentials. These studies will be necessary to assess the air quality impacts of full-scale geopressured resource development.

\section{Data Availability}

The ambient air quality data available from LACC monitoring stations and as a result of special studies were reviewed above in the discussion of air quality characteristics and regulation. Data from these stations and studies will not provide sufficient information for assessing air quality impacts from geopressured resource development. As noted above, the areas for which ambient air data are available lie on the periphery of the potential geopressured development area. No data are available routinely for the Louisiana coastal marsh areas which include a number of prime geopressured prospects.

Coverage in terms of meteorological and climatological data useful for mesoscale atmospheric dispersion studies is somewhat better, but data are still lacking for microscale analyses. The best routine meteorological and climatological data in the study area are found in the publications of the National Oceanic and Atmospheric Administration (NOAA). These are available primarily from the National Climatic Center (NCC) at Asheville, North Carolina. Data in these publications are from the first-order and cooperative stations of the National Weather Service. Pertinent data is collected and sometimes published by other federal organizations such as the U.S. Army Corps of Engineers; 
the Federal Aviation Administration; the U.S. Army, Navy, Air Force, and Coast Guard; U.S. Fish and Wildlife; by state agencies such as the Louisiana Forestry Commission and the Louisiana Department of Wildlife and Fisheries; by universities, municipal agencies, and private citizens.

The National Weather Service first-order weather stations in the study area are located at Lake Charles Municipal Airport, Baton Rouge Ryan Airport, New Orleans Moisant Airport, and at Boothville in the lower delta of the Mississippi River below New Orleans. Hourly observations by well-trained personnel are taken at the first-order stations, and much of these data are published in various formats (Table V-B-2). These are the data which Muller has reorganized by synoptic weather types as his baseline sites (Muller, 1977). The first-order station data go back into the decade of the 1950's without major station relocations, except at Boothville where the station was relocated from Burrwood in 1965 after the destruction wrought by Hurricane Betsy. These data are available for mesoscale atmospheric dispersion analyses, but solar radiation is measured only at Lake Charles.

The National Weather Service also maintains a network of cooperative stations where daily maximum and minimum temperatures and daily precipitation are measured. In the entire state there are about 150 of these stations, but there are so few of these stations in the coastal wetlands that it is even difficult to establish firmly the gradients of mean temperature and precipitation near the coast. A few of these cooperative stations are also equipped 
Table V-B-2. Meteorological data collected at National Weather Service first-order stations.

Hourly surface observations of:

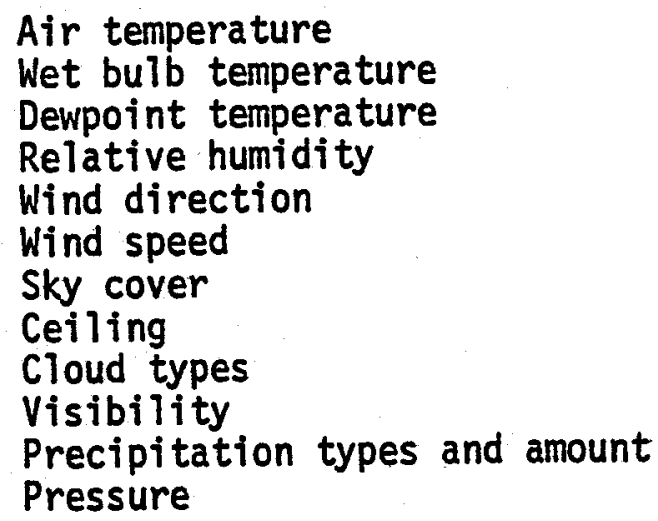

Solar radiation (Lake Charles only)

Radiosonde data--temperature, pressure, humidity, wind direction and speed aloft (Boothville and Lake Charles only). 
with a recording rain gauge in order that precipitation can be published on an hourly basis. The cooperative station data are not adequate for microscale analyses of atmospheric dispersion, but these data have been utilized to establish coastal temperature and precipitation gradients by synoptic weather types (Muller and Wax, 1978).

Other federal and state agencies obtain some climatic data in the Louisiana wetlands. At Coast Guard stations, for example, air temperature, and wind speed and direction are recorded every three hours, and usually precipitation, once every 24 hours. The National Climatic Center at Asheville, and their unofficial representative in the state, Dr. Robert A. Muller, Dept. of Geography, Louisiana State University, Baton Rouge, maintain inventories of most of the climatic data of the state. Available publications giving meteorological and climatological data for Louisiana are as follows:

Climatological Data, Louisiana. National Climatic Center, Asheville, NC, 28807. Published monthly and annually. Includes dally precipitation at nearly 150 first-order and cooperative stations, daily maximum and minimum temperatures at about 75 stations, daily maximum and minimum soil temperatures at 8 stations, and daily evaporation at 5 stations.

Local Climatological Data. National Climatic Center, Asheville, NC, 28801. Published monthly and annually for the first-order stations at Baton Rouge, Lake Charles, and New Orleans. The publication includes a selection of data at 3-hour intervals, including air temperature, dewpoint temperature, relative humidity, wind direction and speed, cloud cover, celling, and visibility. Hourly precipitation are also included. Observations for every hour are available on microffche and computer tapes.

Climatological Data, National Sumary. National Climatic Data, Asheville, NC, 28801. Published monthly and annually. This publication includes daily solar radiation data for Lake Charles and mean monthly radiosonde data for 
Boothville and Lake Charles (mean monthly temperature, humidity, wind speed and direction, and pressure at ten or more levels of the atmosphere).

Index of Original Surface Weather Records, Louisiana. National Climatic Center, Asheville, NC, 28801. Index of hourly, synoptic, and autographic data on file at the National Climatic Center, including some data not published by NOAA agencies. Arranged alphabetically, by year, and by latitude. 


\section{PLAN FOR THE ACQUISITION OF DATA FOR THE ASSESSMENI OE POTENTIAL ENVIRONMENTAL IMPACTS ONAIB QUALITY}

\section{Fixed Location Monitoring Stations}

Clearly, the ambient air quality data previously discussed is insufficient to provide a true measure of the air quality baseline in the rural portions of the geopressured prospect area.

It is recommended that three fixed location monitoring stations be installed at the approximate sites shown in figure $\mathrm{V}-\mathrm{C}-1$. These sites should be fully operational at least one year prior to the first anticipated geopressured activity. All stations should be fully equipped to obtain meteorological data.

The recommended sites provide good east-west coverage of the geopressured prospect area and each is located near currently defined prime prospect sites. The Cameron Parish monitoring station should be located approximately due south of Lake Charles so that previous air quality degradation caused by that industrial center may be measured. Air quallty impacts from Lake Charles industries will be most apparent during the $\mathrm{CH}$ and FOR synoptic weather types. During the $C R, G R$, and FGR types the "natural" background of properties of air off the Gulf of Mexico can be monitored (See Table V-A-1 for the characteristics of synoptic weather types).

The Vermilion Parish monitoring station should be located north of Pecan Island. The site is far enough removed from major industrial areas so that the baseline data should represent conditions, during all weather types, without the significant influence of industrial activities. 


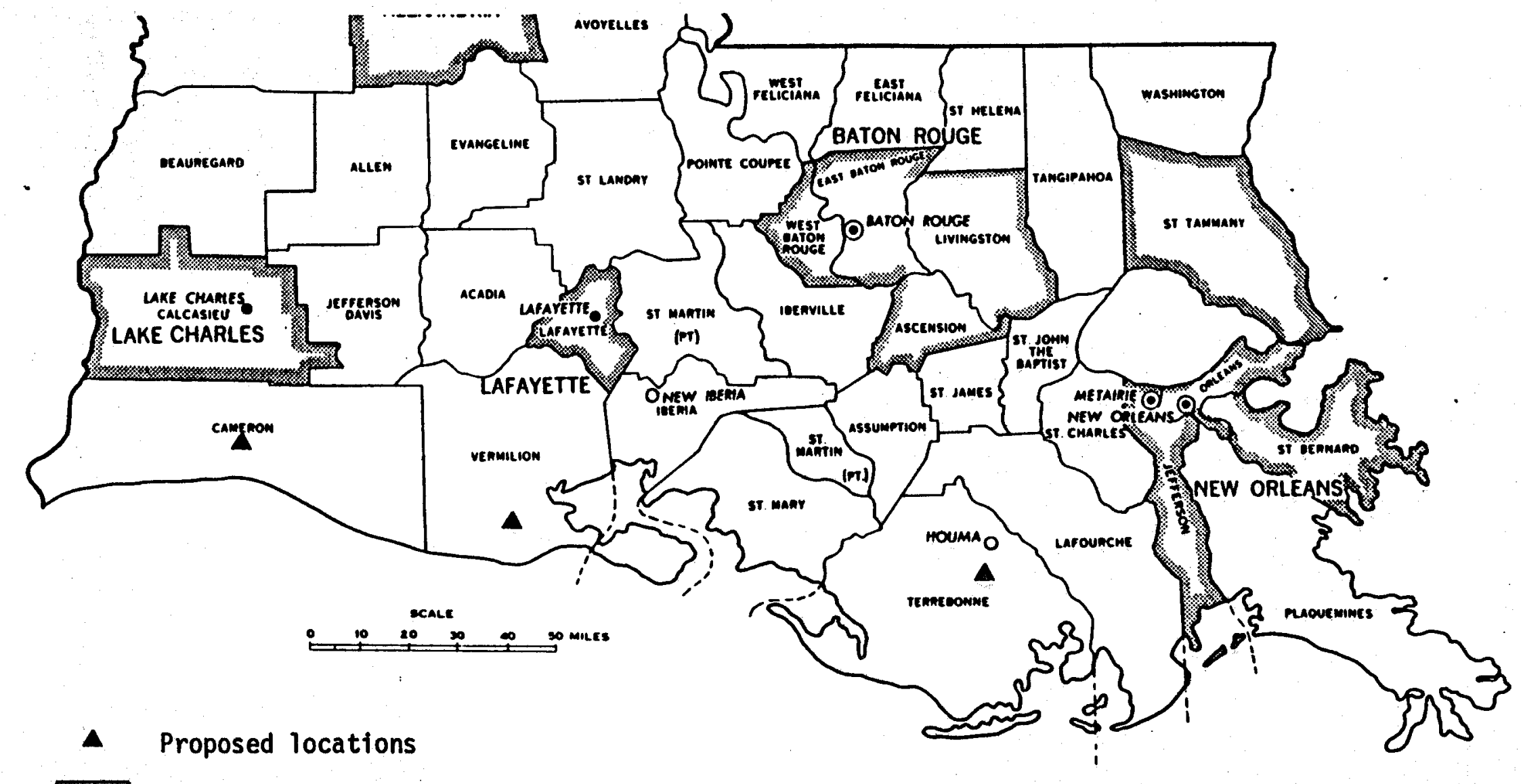

Metropolitan areas

Fig. V-C-1. Locations of proposed air quality monitoring stations. 
The Terrebonne monitoring site possesses many of the same properties as the Cameron Parish site. It should be located approximately 80-100 km (50-60 miles) southwest of the major industrial concentrations a long the Mississippi River near New Orleans, and may show present air quality degradation because of those activities.

The exact location of these stations will be specified once budgetary approval has been obtained. Factors to be considered in specifying the exact site location include proximity to current point sources, the availability of land (preferably accessible by road) and the availability of electric power.

Parameters to be measured at these stations were discussed above in Section $V-B$. Table $V-B-1$ gives a list of these.

\section{Program Costs and Reporting}

It is suggested that the air quality monitoring program recommended here be contracted to a company specializing in such work. A number of companies are currently active in work of this type throughout south Louisiana. Such a contract shouid be awarded on the basis of competitive bids with the supplier assuming full responsibility for site development, installation, operation, and maintenance of instruments, and reporting. Monthly and annual reports would be needed. Both raw data and the monthly and annual reports should be transmitted to that organization having responsibility for overall geopressured energy development environmental impact assessment. 
It is estimated that such services can be obtained for approximately $\$ 150,000$ annually per land-based station. Off-shore sites will require special data telemetry capabilities and will incur added costs associated with site access by boat or helicopter. A total annual cost of $\$ 450,000$ for air quality monitoring is estimated. Dispersion modelling studies are not included in this cost estimate. It is recommended that dispersion modelling work be conducted, or at least coordinated, by that organization responsible for the overall environmental assessment.

\section{Site Specific Monitoring}

In recommending these three baseline stations, we are in no way implying that no additional air quality monitoring work will be needed. The stations are intended to provide necessary baseline data only. Once specific sites have been selected and operations initiated, additional fixed monitoring stations may be needed. In addition, once geopressured operations begin at a certain site, it may be highly desirable to conduct mobile testing to determine such parameters as upwind and downwind concentrations. Emission testing from geopressured operations will also be necessary. 


\section{WATER QUALITY}
A. Rationale
B. Data Requirements and Availability
C. Plan for Acquisition of Data for the Assessment of Potential Environmental Impacts on Water Quality 


\author{
VI. WATER QUALITY \\ C. F. Bryan, R. A. Muller, R. E. Wilcox, \\ J. P. Newman, R. K. Hilding, and K. J. Cunningham
}

The purpose of this section is to provide the rationale and plan for the assessment of potential environmental impacts to water quality from geopressured resource development in Louisiana.

\title{
A. RATIONALE
}

\section{Introduction}

The discussion in this section focuses on the impacts on surface water and ground-water quality from two general occurrences that could take place in the course of geopressured resource development. First is the direct introduction of suspended and dissolved materials into receiving waters as the result of either planned activities or accidental events. Second, the hydrologic changes that could result from construction activities and from subsidence induced by production of the geopressured fluids will be reviewed here. These include changes in water circulation and drainage patterns, and salt and freshwater intrusions. The subject of the effects of water quality and hydrologic changes on the biota of the study area is reserved for the section on ecosystem quality (Section VII).

It has been assumed for this study that suitable aquifers for subsurface disposal of fluids are available. Therefore, the location of suitable aquifers is not a part of the proposed plan for assessing ground-water impacts. Impacts on ground-water quality arising from overpressuring disposal aquifers and other accidental occurrences are identified here, however. 
The rationale for the plan proposed here is based on both the description of the proposed activity and resource characterization presented in Section III; and on a consideration of the cumulative effects on hydrologic patterns of large-scale development in the study area.

\section{Environmental Setting}

a. Surface Hydrology

Three broad geographic divisions can be made of the surface hydrology in south Louisiana: (1) the Mississippi River and its distributaries in the eastern part of the study area; (2) the local drainage systems in the western part of the study area; and (3) the local drainage into Lakes Pontchartrain and Borgne. These three divisions have been further divided into 9 drainage basins (Figure VI-A-1). The Breton (hydrologic unit II), Lower Delta (III), Barataria (IV), and East and West Atchafalaya basins ( $V$ and VI) are associated with the Mississippi River system. The natural levees of the Mississippi River and Bayou Lafourche act as drainage divides. The Atchafalaya River levees separate East and West Atchafalaya floodways north of Interstate 10. During low water east and west floodway basins drain into the river; during high water the river overflows into the lower basins below Interstate 10. Only historical floods inundate floodways north of Interstate 10. Several rivers such as the Pearl, Tangipahoa, and Amite, drain into Lakes Ponchartrain and Borgne (I). The Teche drainage subdivision also includes the Vermilion River drainage (VII). The Mermentau (VIII) and Calcasieu (IX) are the remaining drainage systems, 


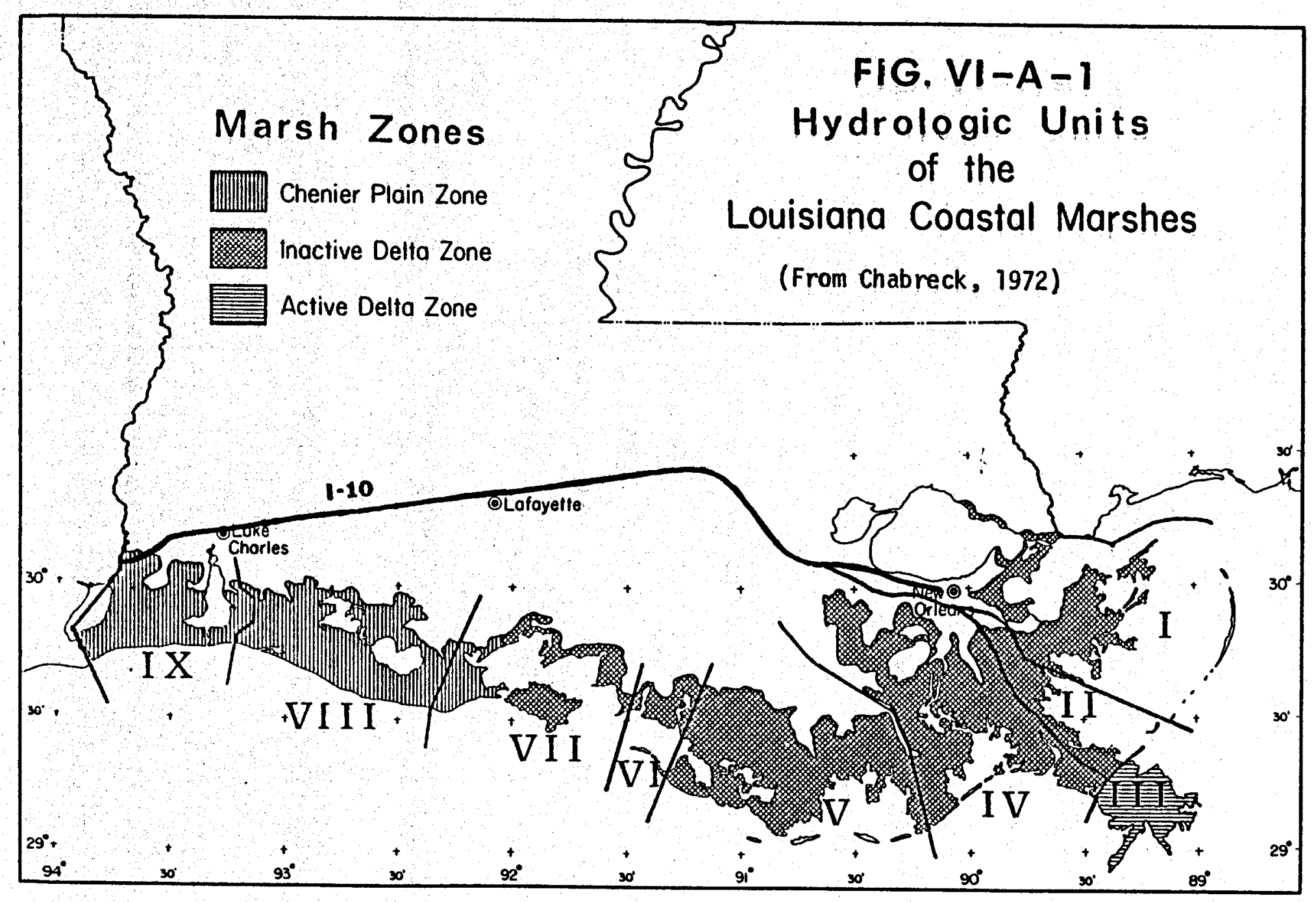


In general, wetland regions in Louisiana are interlaced with bayous and with canals dug for access and navigation. Numerous small lakes, as well as large ones like Lake Calcasieu, Grand Lake, and Lake Salvador, dot the coastal portions of the study area.

Natural drainage is generally southward toward the Gulf. However, drainage is frequently diverted or intercepted by flood control structures, channelization, canals, and the like. Interception and diversion of local drainage channels within swamps and marshes of wetlands simply results in a very local redirection of slow-moving surface water. However, there are a number of indirect and inadvertant consequences of access and navigation canals which have profound impacts on wetlands.

Canals which reach estuaries or the coastline permit intrusion of saline or brackish water far inland into zones which normally would be fresh; consequently, the flora and fauna gradually respond to the altered environments, and obligate fresh-water species are replaced with other, more euryhaline, species.

Spoil banks tend to impede drainage from adjacent swamps and marshes into canals, and in some cases, accidental impoundments with very restricted surface drainage and minimal circulation are produced. The flora and fauna of poorly-drained areas and impoundments are altered dramatically, and usually for the worse from an environmental perspective. Nevertheless, the spoil banks, if large enough and well drained, serve as "islands" where exotic flora and fauna can be established.

In addition, canal dredging converts swamp and marsh instantly to open water. Subsequent erosion of canal banks, especially by wash from passing boats, results in an ongoing but gradual "land loss". 
Some of the marshes have been criss-crossed by so many canals for various purposes that wetlands have been converted essentially to broad bays and lakes within just a few years.

In southwestern Louisiana, canals have been dug across the grain of the natural drainage of the Pleistocene Terrace. These canals divert both surface waters and ground water for rice production. Consequently, natural flows in local streams and rivers become more variable.

Rainfall in south Louisiana is usually abundant and fairly evenly distrubuted through the year. Periods of moisture deficits-water shortage for vegetation--have occurred, nevertheless, especially during the hot summer months when evapotranspiration rates are high, and into autumn when rainfall tends to be lower than other seasons. Southwest Louisiana seems to be more susceptible to deficits, which have on occasion been as much as $46 \mathrm{~cm}$ (18 inches) in a year. Winter-spring surpluses for runoff have averaged from $35 \mathrm{~cm}$ (14inches) near the coast to over $50 \mathrm{~cm}$ (20 Inches) inland (Muller, 1975).

The hydrology of the coastal wetlands has special characteristics. Flow rates are considerably slower than in open streams and are often influenced by wind and tides. Although there is a net discharge of water Gulfward, reversals occur which result in salt water intrusions. Salinities grade from fresh to brackish to salt in marshes, depending on fresh water input. During dryer years salinities in wetlands increase as brackish and salt waters encroach in1and. During wetter years the opposite situation occurs. These shifts have an important impact on wetland ecosystems. 


\section{b. Ground-Water Hydrology}

Aquifers containing potable water in Louisiana are found in geologic formations ranging in age from Pliocene--Miocene to Holocene. Ground water in the state is usually associated with sand or sand and gravel deposits. Salt-water encroachment in coastal areas, caused by the lateral and/or upward migration of salt-water, is always a probiem. Reversal of contamination is difficult to correct and may require pumping fresh water back into an aquifer.

Miocene fresh-water aquifers are confined to a broad eastward trending belt in central Louisiana (Figure VI-A-2). The Miocene strata consist of lenticular beds of fine to medium sand interfingered with silt and clay. Approximately $30^{\circ} 30^{\prime}$ north latitude is the southern limit of fresh water and represents the boundary between fresh water and connate salt waters which, by natural processes, are being flushed southward or downdip within the aquifer (U.S. Army Corps of Engineers, 1976).

Pliocene fresh-water aquifers are limited to an eastward trending belt in south central Louisiana (Figure VI-A-2). The sediments are fine-grained lenticular, deltaic sand, clay and silt, which are lignitic and slightiy calcareous. The boundary between fresh water and connate salt water is approximately $35^{\circ} 25^{\prime}$ north latitude. Flushing of the connate salt water (southward) is still occurring as in the Miocene series (U.S. Army Corps of Engineers, 1976).

Fresh water within the Quaternary system occurs throughout most of south central and northeastern Louisiana (Figure VI-A-2). Approximately two-thirds of all ground-water withdrawals in Louisiana are from Quaternary sediments. The Pleistocene strata are composed of a gulfward thickening wedge of deltaic sediments and thin deposits 
Fig. VI-A-2. Maps illustrating the availability of fresh ground-water in soutn Louts1ana. (From U.S. Corps of Engineers, 1976).

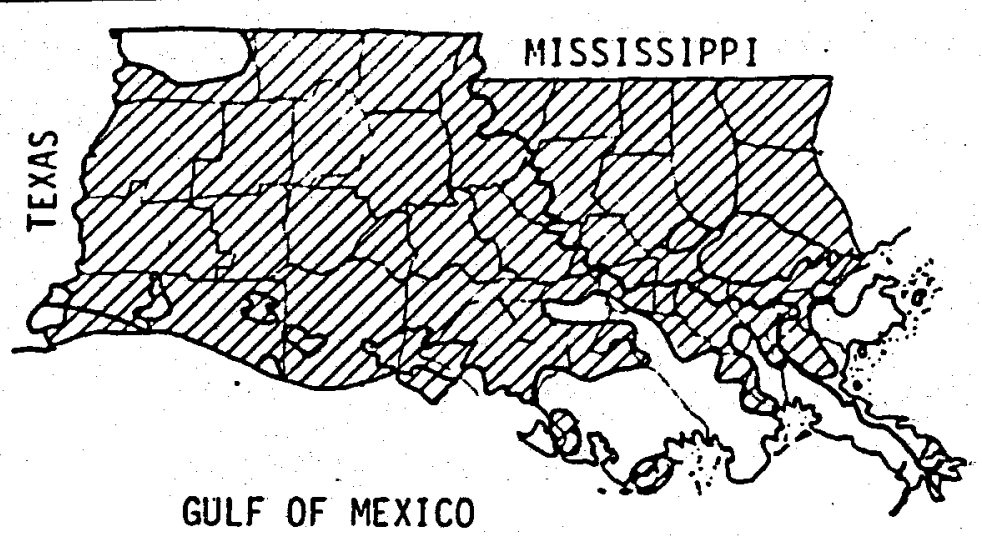

Map showing the approximate area where rocks of the Quaternary system contain fresh water.

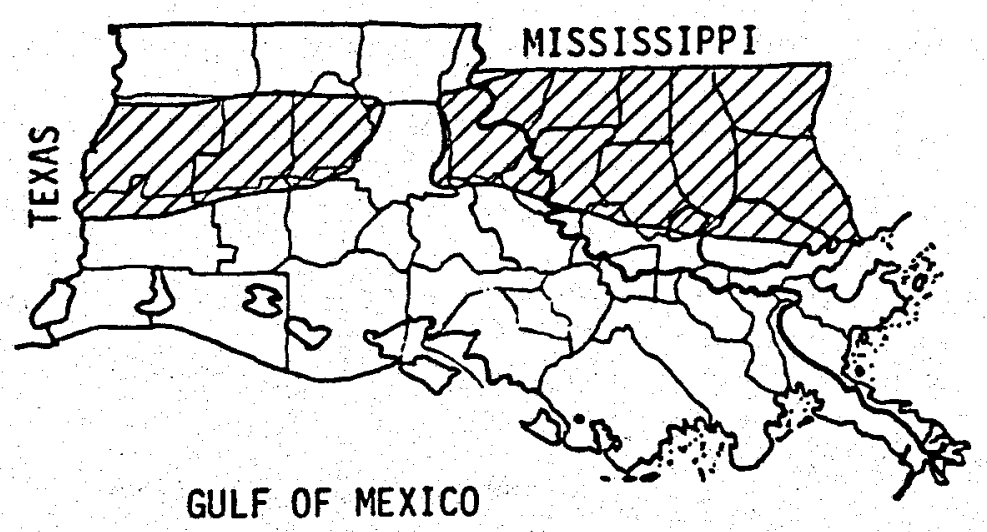

Map showing the approxima te areas where rocks of the Pliocene series contain fresh water.

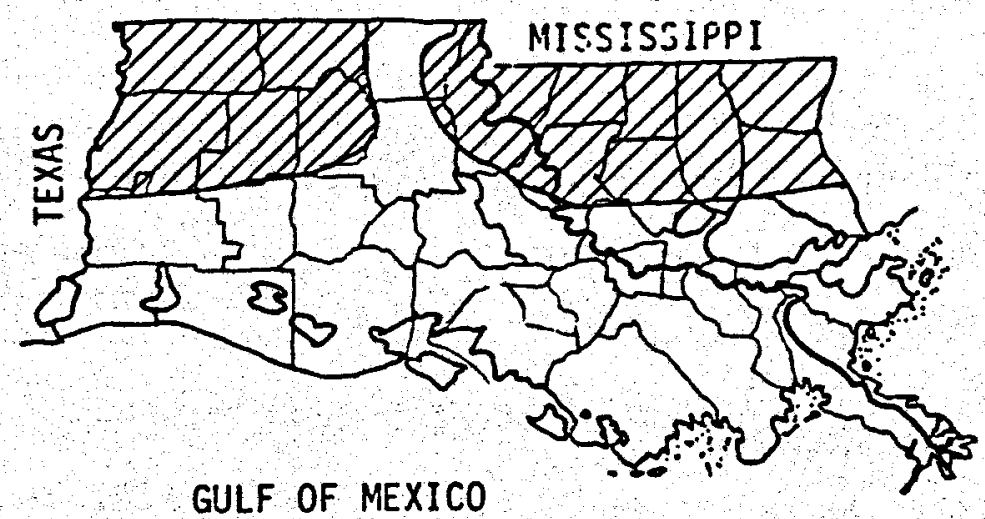

Map showing the approximate area where rocks of the Miocene series contain fresh water. 
of stream terraces and valley fills. The Holocene sediments form a thin veneer of sand, silt and clay. Fresh water is generally limited to north of the $30^{\circ}$ North latitude except for fresh-water lenses contained in minor sandbars (U.S. Army Corps of Engineers, 1976).

\section{c. Water Usage}

Surface waters of southern Louisiana are used for many commercial, industrial, municipal, agricultural, and recreational purposes. The Gulf of Mexico and many of the bays and estuaries are rich commercial fishing grounds for finfish such as menhaden, and shellfish such as shrimp, oysters, and crabs. Crawfishes are "farmed" in artificial ponds, mostly in the south central and southwest parts of the state. The overwhelming portion of water used for agricultural purposes goes into irrigating rice fields in southwest Louisiana. The demand exists only between April and September; no utilization occurs in other months.

Most surface waters for industrial processes, cooling, and dilution of waters are drawn from the Mississippi River from north of Baton Rouge to New Orleans where a concentration of chemical, petroleum, and primary metal (mostly aluminum) plants have been established. Almost all municipal water supplies in southeastern Louisiana are dependent on such surface waters as the Mississippi River, Bayou Lafourche, and Gulf Intracoastal Waterway. Other sections of south Louisiana rely on ground-water sources (Louisiana Department of Public Works, 1969). 
Natural waterways have been well developed for navigation, and thousands of miles of canals for just about every purpose have been dredged across wetland swamps and marshes. Coastal waters and wetlands of Louisiana also offer major recreational opportunity where fishing and boating can be enjoyed practically year round.

Ground water is used for a variety of purposes in southern Louisiana, including domestic usage, industrial usage, livestock and agricultural needs. In southwestern Louisiana, three-fourths of all ground water pumped is used for rice irrigation. Industrial and agricultural development has increased in southern Louisiana, creating a heavier demand on ground-water resources (U.S. Army Corps of Engineers, 1976).

d. Water Quality Characteristics and Regulation

Surface Water. Surface water quality comes under the jurisdiction of the Louistana Stream Control Commission (LSCC). The LSCC has permitting authority for discharges of fluids into state surface waters, including discharges into the open Gulf (LaFleur, personal communication, 1977).

The LSCC has issued extensive regulations concerning the disposal of oil field brines. These could be extended to spent geopressured fluids into surface streams (Harrel1, 1978). However, it has been assumed for the purposes of this assessment, that surface disposal of spent geopressured fluids into fresh-water systems will not be feasible. 
Louisiana law prohibits disposal of saline water into natural streams when that disposal is "in quantities to destroy the fish therein" (La. Revised Statutes 56:1451; Harre11, 1978). Geopressured fluids are expected to meet this criterion. They probably have high salinities and will be produced in large quantities. Robert LaFleur, Executive Secretary of the Louisiana Stream Control Commission has confirmed this analysis (Lafleur, personal communication, 1977).

The LSCC promulgates and enforces water quality standards for surface waters. The most recent numerical standards are surmarized in Table VI-A-I for the major basins in South Louisiana. Specific standards for sub-basins are found in LSCC reports (e.g., LSCC, 1977). Numerical standards for bacteria have also been promulgated, General criteria are stated for the following additional parameters: aesthetics, color, floating, suspended and settleable solids, taste and odor, toxic substances, oils and greases, foaming or frothing materials, nutrients, turbidity and other materials. These standards apply only to water bodies and not to effluents. There are no state standards for effluents at the point of outfall.

Surface water quality within the study area is highly variable. Waters from the Mississippi and Atchafalaya Rivers are generally high in suspended solids and total dissolved solids. To the west, waters in the Chenier Plain are derived from indigenous rainfall and differ in the amounts and kinds of dissolved and suspended materials. 
Table VI-A-1. Louisiana water quality criteria for major basins in south Louisiana, (From La. Stream Control Commission, 1977).

\begin{tabular}{|c|c|c|c|c|c|c|}
\hline Basin & Chloride & Sulphate ${ }^{2}$ & $00^{3}$ & $\mathrm{pH}^{4}$ & Temp. 5 & $\mathrm{TDS}^{6}$ \\
\hline Atchafalaya & $65-150$ & $70-75$ & $4.0-5.0$ & $6,0-9.0$ & $32-35$ & $427-1320$ \\
\hline Barataria & $65-1000$ & $50-500$ & $4.0-5.0$ & $6.0-9.0$ & $32-35$ & $1320-2000$ \\
\hline Calcasieu & $20-250$ & $20-250$ & $2.0-5.0$ & $6.0-9.0$ & $30-35$ & $100-600$ \\
\hline Mermentau-Vermilion-Teche & $10-250$ & $5-75$ & $4.0-5.0$ & $6.0-9.0$ & $30-35$ & $100-500$ \\
\hline Mississippi & $75-100$ & $75-120$ & $4,0-5,0$ & $6.0-9.0$ & $32-35$ & $400-500$ \\
\hline Pear1 & $15-30$ & $12-50$ & 5.0 & $6,0-9.0$ & $30-35$ & $105-300$ \\
\hline Pontchartrain & $6-1000$ & $5-1000$ & $4.0-5.0$ & $6,0-9,0$ & $30-35$ & $54-3000$ \\
\hline Sabine. & $15-150$ & $7-200$ & $4,0-5,0$ & $6.0-9.0$ & $32-35$ & $90-1000$ \\
\hline Terrebonne & $25-250$ & $25-75$ & $4.0-5.0$ & $6.0-9.0$ & $32-35$ & $200-875$ \\
\hline
\end{tabular}

\footnotetext{
1. 2 Chlorides expressed in ppm; range of highest allowed, sub-basins. 2 3 Sulphates expressed in ppm; range of highest allowed, sub-basins. Dissolved Oxygen expressed in ppm; range of lowest allowed, sub-basins. 5 $\mathrm{pH}$ expressed in pH units; range of lowest and highest allowed throughout basin. Temperature expressed in degrees Celsius; range of highest allowed, sub-basins. 6 Total Dissolved Solids expressed in ppm; range of highest allowed, sub-basins.
} 
Waters influenced by the Gulf of Mexico range from slightly saline to sea water salinities. Waters near population and industrial centers, such as Mississippi River, Lake Pontchartrain, Vermilion River, and Calcasieu River, have high loadings of a number of pollutants due to industrial effluents, municipal. runoff, boat traffic and agricultural runoff.

A major agency in the state monitoring water quality is the U.S. Geological Survey. Raw data for Louisiana are published yearly (USGS, 1971-1977). The Louisiana Stream Control Commission also regularly monitors water quality for compliance with state standards. The stations monitored by the USGS are shown in Figures VI-A-3 and 4 while the stations sampled by the Louisiana Stream Control Commission are shown in. Figure VI-A-5. Characteristics regularly measured by these agencies are summarized in Table VI-A-2.

Ground Water. Jurisdiction for the subsurface disposal of brines and other waste lies with the Office of Conservation, Louisiana Department of Natural Resources. The Office of Conservation issues permits for the drilling of disposal wells and has the authority to shut in disposal wells should significant problems arise. The Geothermal Resources Energy Act specifically grants the regulation of the subsurface disposal of water from geothermal/ geopressured fields to the Commissioner of Conservation (La. Revised Statutes 30:802; Harre11, 1978). The Commissioner's proposed regulations for this disposal exhibit three primary concerns: that subsurface. disposal will not foul fresh or brackish water aquifers; that subsurface disposal will not impinge on production of oil and gas; and that disposal well completion should be adequate to minimize the risks of leakage (Harrel1, 1978). 


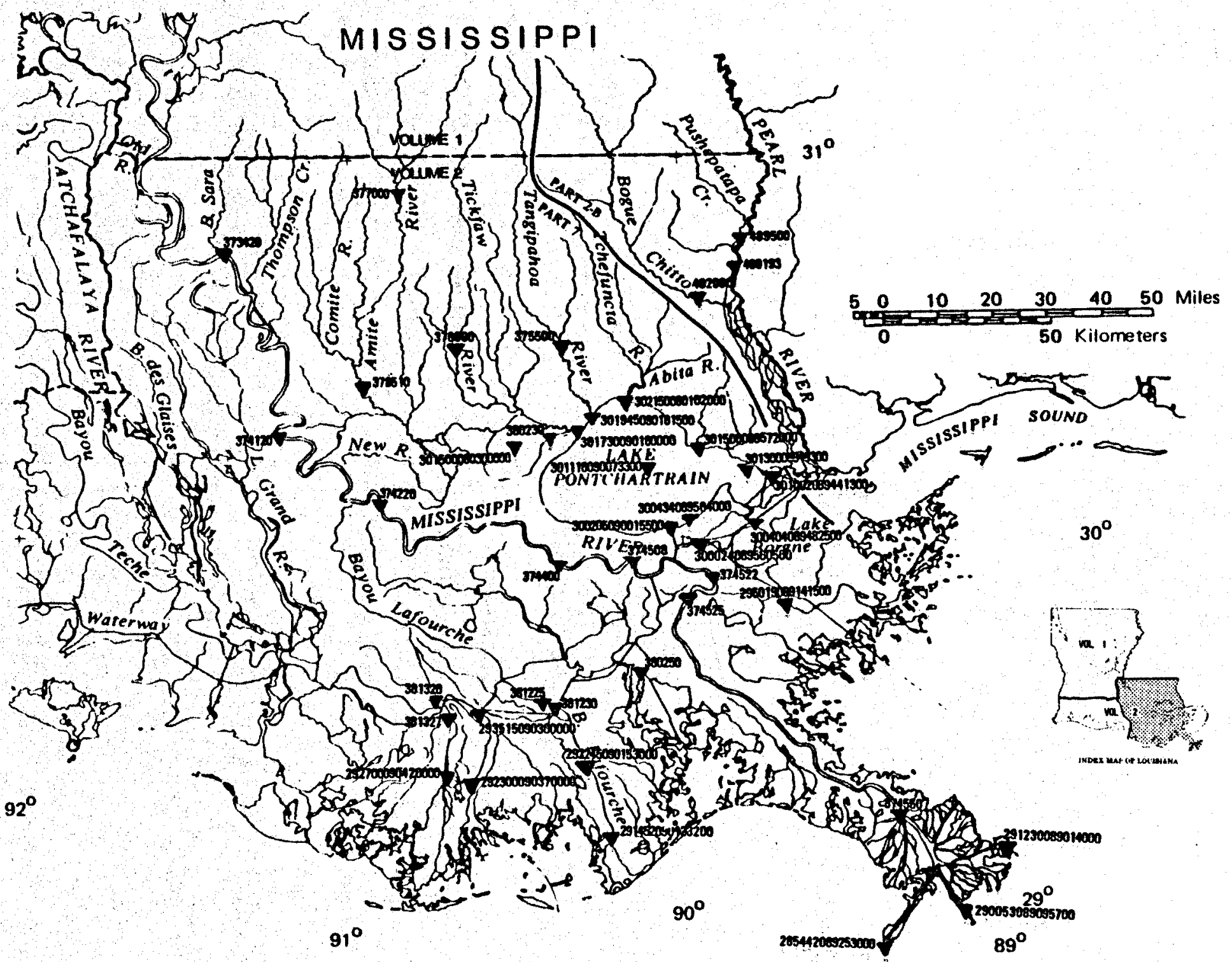

Fig. VI-A-3. U.S. Geological Survey water quality sampling stations, southeastern Loutstana. (From USGS, 1976). 


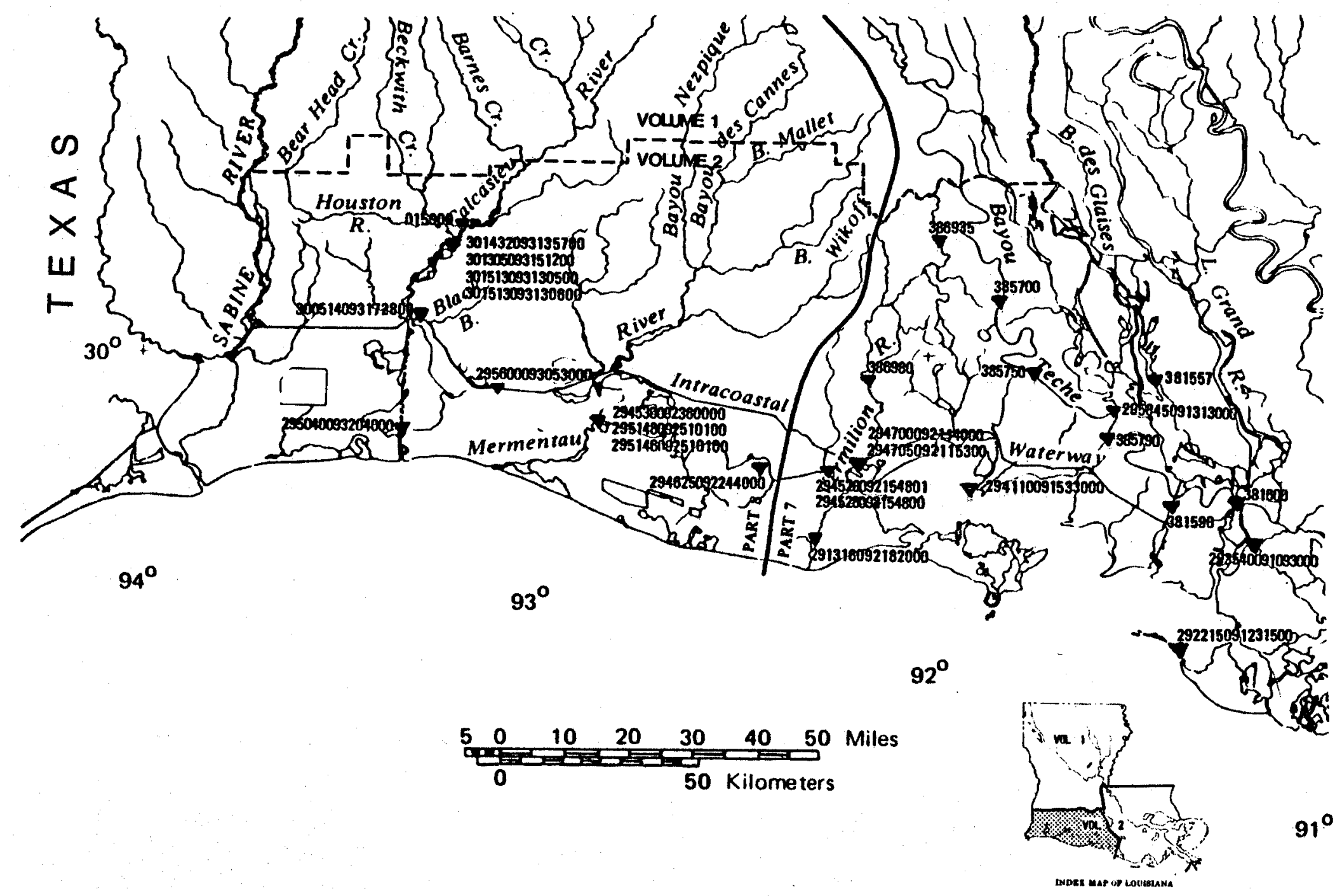

兽

Fig. VI-A-4. U.S. Geological Survey water quality sampling stations, southwestern Loutsiana. (From USGS, 1976). 


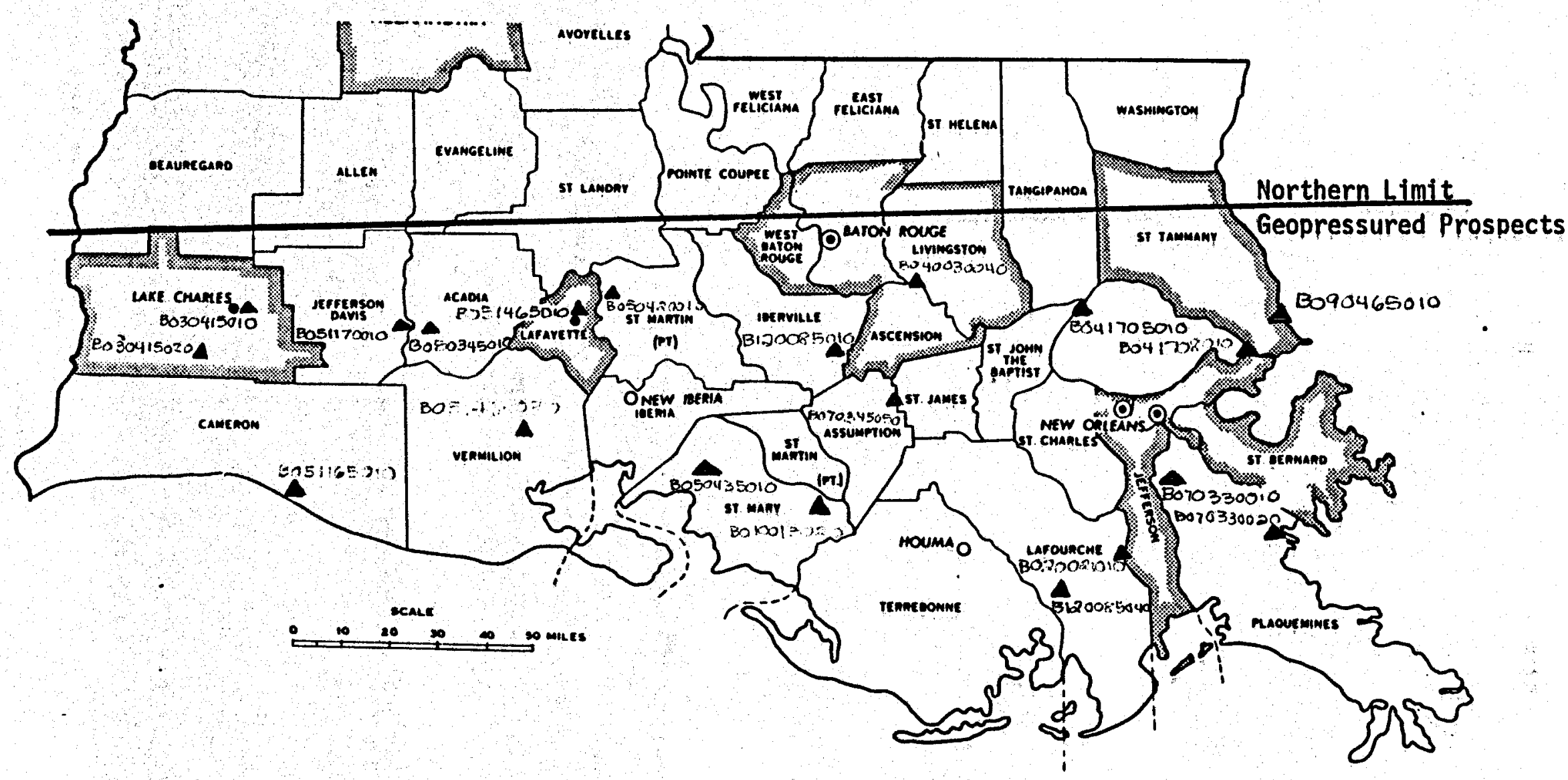

Fig. VI-A-5. Louisiana Stream Control Commission water quality monitoring stations, study area. (LSCC, 1978). 
Table VI-A-2. Surface water quality characteristics monitored-by the U.S. Geological Survey and the LouTstana Stream Control

Commission.

\section{U.S. Geological Survey}

Dissolved Iron

Dissolved Calcium

Dissolved Magnesium

Bicarbonate

Carbonate

Dissolved Sulfate

Dissolved Chloride

Total Nitrate

Total Nitrite

Total Nitrate \& Nitrite

Dissolved Kjel. Nitrogen

Total Phosphorus

Suspended Solids

Settleable Matter

Hardness

Non-carbonate Hardness

Specific conductance

$\mathrm{pH}$

Temperature

Color

Turbidity

Dissolved Oxygen

Chemical Oxygen Demand

Biochemical Oxygen Demand

Immediate Coliform

Fecal Coliform

Total Organic Carbon

Cyanide

Phenols

011 and Grease

Numerous Biocides

PCB

Total Arsenic

Total Cadmium

Total Chromium

Hexavalent Chromium

Total Copper, Dissolved Copper

Total Lead, Dissolved Lead

Total Mercury, Dissolved Mercury

Suspended Mercury

Total Nickel, Dissolved Nickel

Total Zinc, Dissolved Zinc
La. Stream Control Comm.

$\mathrm{pH}$

Secci Disc

Temperature

Dissolved Oxygen.

Salinity

Alkalinity

Hardness

Turbidity

Specific Conductance

Sulfate

Color

Chlorides

Total Solids

Dissolved Solids

Suspended Solids

Arsenic

Cadmium

Chromium

Copper

Mercury

Lead

Nitrate

Nitrite

Total Kjel. Nitrogen

Total Phosphate

Chemical Oxygen Demand

Total Organic Carbon 
The primary concern in south Louisiana with respect to ground-water quality is salt-water encroachment due to ground-water withdrawal. The natural movement of ground water in south Louisiana is in a southward direction. However, heavy pumpage reverses this tendency and the movement of salt-water north into aquifers occurs (U.S. Army Corps of Engineers, 1976).

\section{Potential Environmental Impacts}

Potential environmental impacts on water quality from geopressured resource development in the study area are discussed below. The identification of these potential impacts and their relative significance in the study area is based on the description of the proposed activity and resource characterization (see Section III) in view of the environmental setting of the study area, as described above. In addition, interviews with representatives of regulatory agencies, research and planning groups, and industries were used to identify impacts and assess their significance.

The identification of impacts and an assessment of their relative significance is constrained by lack of data on the chemical and physical properties of geopressured fluids. At the present time, the properties of geopressured fluids that make its disposal or accidental release problematic are salinity, temperature and total quantity of heat to be dissipated, lack of dissolved oxygen content, possible toxic amounts of $\mathrm{H}_{2} \mathrm{~S}, \mathrm{NH}_{3}$, copper, boron, radon, and other lons. Analys is of geopressured fluids, once testing and production take place, may reveal other properties detrimental to water quality.

Another area which is difficult to assess at this time is the impacts on water quality that would result if subsidence occurs in wetland regions. 
Available data are inadequate for an assessment of either the probability of subsidence occurring or an estimation of how much subsidence could occur (see Section VII). The approach taken here is to assume the worst case; i.e., that enough subsidence could occur to inundate wetland systems.

\section{a. Fluid Disposal}

It is assumed that surface disposal of spent geopressured fluids will be possible only into the open waters of the Gulf of Mexico. Whether permits can be obtained for such discharges will depend on the physical. and chemical characteristics of the spent fluids. At present, no permitted discharges of the quantity and duration hypothesized for fullscale geopressured development are permitted into Louisiana Gulf coastal waters (LaFleur, personal communication, 1977). Should a permit be granted for disposal of geopressured brines, continued monitoring should be performed to insure that heat and dissolved solids are adequately dispersed, and that toxic substances, if present, do not result in fish kills or significant migration from traditionally used spawning and feeding areas.

Subsurface disposal of spent geopressured brines is the most likely disposal alternative given the constraints on surface disposal. The potential environmental hazard from subsurface disposal is the fouling of fresh-water aquifers and surface waters. This could result from increased pressure in the receiving aquifer which could cause the upward flow of injected spent fluids along fault planes, or through permeable strata, or leakage through abandoned wells in the vicinity.

The key to avoiding these effects is the availability of adequate receiving aquifers with thick sands and favorable permeability and porosity. The aquifers should be at least 300-450 meters (1000-1500 ft) below the 
base of fresh water and bounded above and below by impermeable shales or clays. Jones (1975) and others (e.g., Bates, personal comunication, 1977) believe such aquifers to be plentiful in the Gulf Coast region. Industry and regulatory agency representatives, however, have expressed concern on this point because of the very large total quantity of spent fluids to be reinjected over the life of a geopressured operation.

At present, the largest subsurface brine disposal programs in Louisiana are those planned for the Strategic Petroleum Reserve program (i.e., Federal Energy Administration, 1977a\&b). The brine is from draining brine stored in cavities in salt domes, al though brine from leaching new cavities for oll storage may also be produced as the program expands. Disposal rates in the Bayou Choctaw salt dome program, for example, will be at maximum 450,000 barrels per day (Everett, personal communication, 1978). Disposal in a fully developed geopressured field, however, would occur at nearly twice that dally rate and for 4-10 times as long a period. Because subsurface injection is likely to be the only al ternative disposal method in the geopressured case, the risk of disposal-related problems should be carefully considered by the geopressured developer.

\section{b. Subsidence}

Subsidence induced by the extraction of geopressured fluids could affect local fresh water discharge and circulation, water levels, drainage patterns, and salinity concentrations. Calculated estimates for Brazoria County, Texas in White, et. al, (1977) indicate that subsidence in a 0.6 kilometer radius of a well could be as much as $30 \mathrm{~cm}$ (about $12 \mathrm{in}$ ). This figure drops to $10 \mathrm{~cm}(4 \mathrm{in})$ at a radius of 6 kilometers. In an environment of very low relief, like the Louisiana wetlands, even minimal 
subsidence could produce marked changes in local drainage. It is possible that extensive inundation and land loss would develop in the area of greatest subsidence. Subsidence would have less effect on natural levee regions in the Mississippi Alluvial Valley and even less effect on the terrace surfaces although swamps and marshes may develop in these low areas, and open water could be increased in areal extent.

c. Site Preparation and Construction

The most adverse potential impact from site preparation and construction is also on drainage patterns and circulation, discharge, and water levels in the vicinity of the geopressured wellfield. The dredging of canals and the construction of impoundments in the wetland portions of the study area have already allowed intrusions of saline waters into previously fresh or brackish water areas. These intrusions have greatly aitered the ecological situation, converting fresh-water marsh into brackishwater marsh. In addition, canals have affected the normally slow discharge and circulation patterns in the marshes and permitted a more rapid flow of waters. Impoundments have created areas cut off from the general discharge and circulation patterns; areas which subsequently develop a minimal circulation and an environment distinctly different from outside the impoundment. Spoil banks and levees can also block circulation if they are oriented across the direction of flow. In general, these activities tend to destroy the character of the wetlands and can cause a drop in productivity as well as land loss (Stone, et. al., 1977; Craig, et. al., 1977; and others).

\section{d. Accidental Brine Spills}

Accidental spills of brines would have a serious impact on water quality in the area of contact. The impact is of less significance 
relative to other impacts on water quality, however, because the effects of a brine spill should be of relatively short duration and localized unless the spill resulted in total destruction of the indigenous biota over a fairly large area. In that extreme case, it would take some time for recolonization of the indigenous biota. (See Section VII). In any case every precaution should be taken to prevent accidents and contain spills should they occur. Brine spills from a geopressured operation will be decidedly more serious than either brine or oil and gas release from conventional otl and gas recovery principally because the volumes of fluid released could be so much greater. It may be more difficult and take longer to bring a geopressured well under control after a blowout. Also, unlike most ofl spills, brine spills cannot be contained and cleaned up if they should reach surface waters.

In general, the actual effects on water quality in the impacted waters will depend on the mixing rate and dilution of the brines, and on the receiving water quality. Impacts from brine spills in offshore geopressured fields would be minimal compared with impacts on fresh-water streams and ponds. Tidal marsh systems are characterized by repeated flushing, so brine spills would be dispersed rapidly into surrounding open water estuarine systems. However, sediments in estuarine systems could trap and release toxic ions into the water column. 



\section{B. DATA REQUIREMENTS AND AVAILABILITY}

\section{Data Requirements}

Data requirements for the long-term assessment of potential impacts on water quality are summarized in Table VI-B-1. These characteristics include the standard analys is suggested by the U.S. Department of the Interior in its publication giving guidelines for the acquisition of environmental baseline data on federal geothermal leases (1977). Additional characteristics have been identified based on what is now known concerning Gulf Coast geopressured fluids (see Section III). However, an accurate identification of data requirements must await further specific analyses of geopressured fluids from Louisiana sites.

In addition to characteristics in the table, surface hydrology and ground-water resources in the vicinity of each geopressured development site should be identified and mapped. It is particularly important to determine circulation and mixing characteristics in wetland areas, the depth to the base of fresh and brackish water, and the direction of ground-water flow. Point and non-point pollution sources should also be identified. Water uses should be determined and a history of pollution sources taken.

The geopressured fluid streams should be sampled over time to determine fluid composition. Water quality analyses might then change as these data become available.

\section{Data Avallability}

Surface water quality data taken by the U.S. Geological Survey and the Louisiana Stream Control Commission have been summarized in Section VI-A. These data may be useful, if USGS and LSCC sampling stations are 
Table VI-B-1. Data requirements for water quality impacts assessment.

SURFACE WATER

discharge

*dissolved solids

*suspended solids

*specific conductance

*temperature

turbidity

biochemical oxygen demand

chemical oxygen demand

total organic carbon

fecal coliforms

fecal streptococcus

SURFACE WATER and GROUND WATER

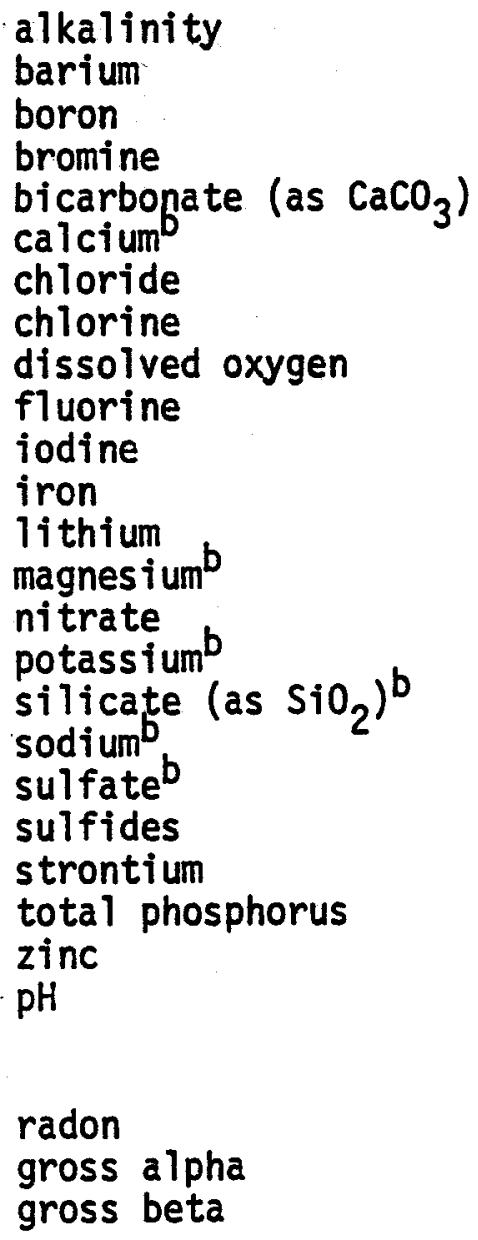

*Ground-water sources should also be measured for these characteristics at minimum. 
located in appropriate positions within geopressured development sites. Water quality data from other sources is frequently insufficient in geographical extent and in the characteristics measured.

Stream discharge data for the study area is also available from the USGS for the gaging stations shown in Figure VI-B-1. Routine daily discharge readings are rare. There are relatively few gaging stations in the coastal wetlands portion of the study area--the region containing the most promising geopressured prospects.

Circulation, mixing characteristics, and currents in coastal areas and estuaries are not well known. This is particularly true for the entire area west of the main Mississippi distributary system (Murray, 1976). However, a number of agencies and research institutions are conducting research on the hydrology of coastal wetlands: the Coastal Studies Institute, Louisiana State University; the Louisiana Department of Wildlife and Fisheries; U.S. Fish and Wildlife Service (Department of the Interior); and the U.S. Army Corps of Engineers, New Orleans District. Again, to assess impacts on water quality from geopressured resource development, hydrologic data must be site specific. Existing studies may therefore be of limited use.

Ground-water studies in south Louisiana are avallable, although north Louisiana ground-water resources have been more extensively studied. Ground-water maps are produced by the Louisiana Geological Survey, and by the U.S. Geological Survey cooperatively with the Louistana Department of Public Works. Data on ground-water pumpage and ground-water quality is also avallable from these agencies. Coverage 


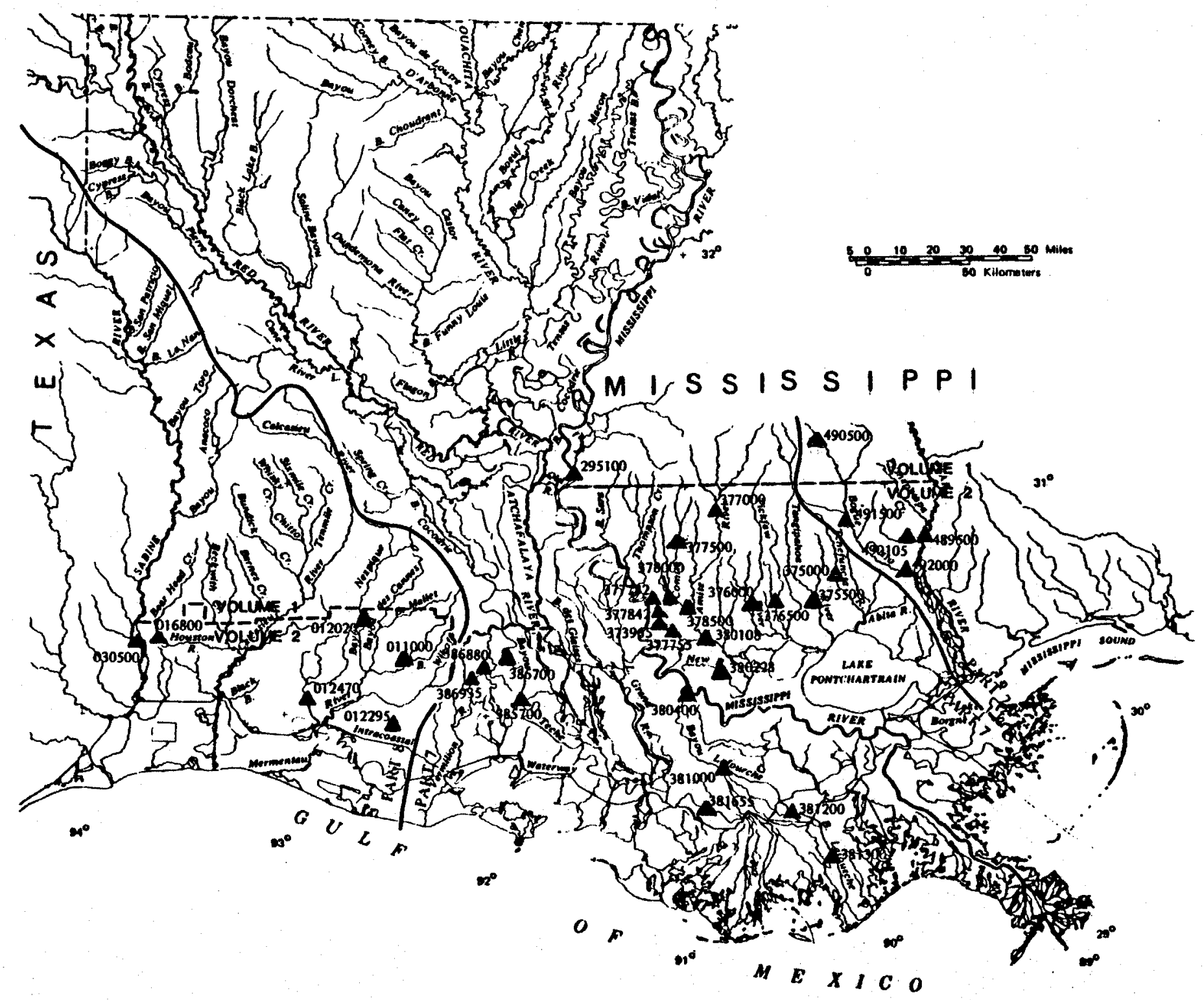

Fig. VI-B-1. U.S. Geological Survey continuous gaging stations, Louisiana. (From USGS, 1976). 
is particularly extensive in southwest Loulsiana where ground water is used to irrigate rice crops. Parish ground-water studies cover usage, physical and hydraulic characteristics, geologic setting, depth and future potential. These studies are published under a cooperative program wi th the Louisiana Geological Survey, the Louisiana Department of Naturat Resources, and the Louisiana Department of Public Works. 
$\mathcal{U}$

$\mathcal{O}$ 


\section{PLAN FOR ACQUISITION OF DATA FOR THE ASSESSMENT \\ OF POTENTIAL ENVIRONMENTAL IMPACTS ON WATER QUALITY}

This subsection deals with a proposed plan for acquiring baseline data on water quality and hydrology at a geopressured site prior to the beginning of production, and for continuing monitoring activities during the lifetime of the project. Water quality data in the largely undeveloped region of prime geopressured prospects--the coastal wetlands--are vital for a determination of impacts on the biota in these areas. Thus, this program should be carried out in close coordination with the program on ecosystem quality (Section VII-C). In most instances, water quality samples should be taken at the same locations as biotic surveys in aquatic and wetland areas. In upland areas, water quality measurements can be taken in open water systems.

\section{Surface Water Quality}

Surface water quality and hydrologic patterns should be carefully monitored since water is used for a wide variety of human activities in the study area and is important to all ecosystem types. Consideration should be given to possible leakage or spills of geopressured brines into fresh-water areas, and to alteration of the hydrology from site preparation and construction activities. These studies should be sensitive to feedback from air and ecosystem quality studies as well as from analysis of geopressured brines.

Surface water uses should be inventoried and pollution sources identified. Water quality characteristics should be measured monthly at an extensive series of stations within the specific site. To establish baseline conditions, sampling should begin as soon as a site is 
chosen, preferably two years before any construction activities. Samling should be done by personnel of the ecosystem quality study (Section VII) and should consist of three 18-month intensive sampling periods coinciding with pre-development, development and operational phases. Parameters to be analyzed should be keyed to possible impacts and include those Jisted in Table VI-B-1 in the preceeding section, as well as any further contaminants identified when geopressured fluids are analyzed. Station locations and sampling dates should coincide with biological sampling (see Section VII). Other stations should be established in relation to possible point and non-point sources of pollution and based on hydrologic regime and placement of geopressured facilities. In upland areas where directional flow exists, sampling should be performed upstream and downstream of any possible geopressured development influence.

Hydrologic characteristics and discharge in the vicinity of the site should be estabiished from previous records and a predevelopment study. This is especially important in the coastal zone where water quality has great influence on productive ecosystems (see Section VII). Discharge should be monitored continuously on major waterways and periodically measured on smaller waterways. Again the coastal zone will receive more effort since tide and weather influences make hydrologic patterns more complex than in upland regions.

The estimated costs of monitoring surface water quality, hydrologic patterns and discharge for a single geopressured development site are shown in Table VI-C-1. 
Table VI-C-1. Estimated costs of performing surface water quality studies at a geopressured site.

\begin{tabular}{|c|c|c|c|c|c|c|c|c|}
\hline \multirow[b]{2}{*}{ ITEM } & 0 & 1 & 2 & ${ }_{3}^{\text {Yea }}$ & 4 & 5 & 6 & 7 \\
\hline & \multicolumn{8}{|c|}{ (thousands of dollars) } \\
\hline $\begin{array}{c}\text { Salaries \& Wages } \\
\text { Wages }\end{array}$ & 13.5 & 13.9 & 14.3 & 14.7 & 15.1 & 15.5 & 15.9 & 16.3 \\
\hline $\begin{array}{l}\text { Benefits \& } \\
\text { Overhead }\end{array}$ & 7.6 & 7.8 & 8.1 & 8.3 & 8.5 & 8.8 & 9.0 & 9.2 \\
\hline $\begin{array}{r}\text { Laboratory } \\
\text { Analysis }\end{array}$ & 13.5 & 10.1 & 6.8 & 13.5 & 10.1 & 6.8 & 13.5 & 10.1 \\
\hline TOTAL & 34.6 & 31.8 & 29.2 & 36.5 & 33.7 & 31.1 & 38.4 & 35.6 \\
\hline
\end{tabular}

${ }^{a}$ Collection of samples will be performed by personnel of the ecosystem quality study (Section VII).

bubcontracted: no laboratory equipment costs incurred.

Years $0,1=$ pre-development

Years $2,7=$ post-development 


\section{Ground-water Quality}

Essential in assessing impacts on ground-water quality is a determination of ground-water uses in the vicinity of the geopressured site. Ground-water sources used for domestic water supply and for agriculture should be mapped. If existing maps are not adequate and if domestic and agricultural uses are widespread, information on the configuration and depth of ground-water aquifers can be obtained from well logs. Induction logs are routinely run on all oil and gas wells and some water wells. For determining information on ground-water aquifers, induction logs run on geopressured wells should give as complete coverage from the surface down as possible on each producing and disposal well in the area of concern.

An annual sampling program should be conducted on ground-water sources used for domestic and agricultural purposes in the vicinity of the site. Sampling should be for specific conductance at a minimum. Other parameters may be added and sampling could occur more frequently if contamination is suspected.

It will be difficult to determine if ground-water contamination, if it should occur, stems from geopressured activities, particularly reinjection of spent fluids. Salt water encroachment on ground-water resources is already widespread in the southwestern portion of the study area. "Fingerprinting" the geopressured fluids definitively may also be difficult, because the contamination will occur as a result of brines migrating from depths of approximately 1500 meters (5000 feet) through non homogenous formations. Information on the direction of ground-water flow will give some indication of the source of contamination. 
If contamination is suspected and existing data are not avallable, observation wells can be drilled to monitor changes in the potentiometric surface and to determine direction of flow in shallow aquifers. A network of observation wells could be required in an area of special concern.

A number of measures can be taken to prevent ground-water contamination as a result of subsurface disposal activities. The Louisiana Office of Conservation, Department of Natural Resources, regulates subsurface disposal, requiring well casing to be placed to depths well below the base of fresh water. The plugging and abandonment of wells is also regulated and records are made of these procedures. Records on all abandoned wells in the vicintty of the geopressured site should be reviewed to see that adequate procedures were used in plugging and abandonment. Improperly abandonned wells could be squeezed and replugged, if they can be located. Alternatively, disposal wells can be relocated or the disposal system re-engineered.

Costs for implementing the plan for the assessment of impacts on ground-water quality at a single geopressured site are given in Table VI-C-2. 
Table VI-C-2. Estimated costs of performing ground-water quality studies at a geopressured site 50-60 sq. mi. in area. ${ }^{2}$

\begin{tabular}{|c|c|c|}
\hline Activity & Estimated Costs & Cost Bases \\
\hline $\begin{array}{l}\text { Determination of ground- } \\
\text { water uses }\end{array}$ & $\$ 750$ per site & $\begin{array}{l}\text { Salaries; one-time } \\
\text { effort }\end{array}$ \\
\hline Mapping sources & $\$ 1,250$ per site & $\begin{array}{l}\text { Salaries; data } \\
\text { available at no } \\
\text { cost; one-time effort }\end{array}$ \\
\hline Induction logs & $\$ 3,000$ per we $11^{b}$ & $\begin{array}{l}\text { Subcontracted; } \\
\text { shallow logs; one- } \\
\text { time effort }\end{array}$ \\
\hline \multirow[t]{2}{*}{ Sampling program } & $\begin{array}{l}\$ 1,000 \text { per site, } \\
\text { per year }\end{array}$ & $\begin{array}{l}\text { Subcontracted; } \\
\text { limited analysis of } \\
6 \text { existing wells }\end{array}$ \\
\hline & $\begin{array}{l}\$ 1,900 \text { per site, } \\
\text { per year }\end{array}$ & $\begin{array}{l}\text { Subcontracted; } \\
\text { complete analysis of } \\
6 \text { existing wells }\end{array}$ \\
\hline \multirow[t]{2}{*}{ Observation wells } & $\$ 75,000$ per site & $\begin{array}{l}\text { Subcontracted; } 3 \\
\text { wells; drilling and } \\
\text { sampling at } 1,000 \text { feet; } \\
\text { one-time effort }\end{array}$ \\
\hline & $\$ 1,500$ per site & $\begin{array}{l}\text { Permanent level } \\
\text { recording device: } \\
\text { installation and } \\
\text { maintenance }\end{array}$ \\
\hline $\begin{array}{l}\text { Location and records } \\
\text { review of abandoned } \\
\text { wells }\end{array}$ & $\$ 750$ per site & $\begin{array}{l}\text { Salaries; records } \\
\text { available at no cost; } \\
\text { one-time effort }\end{array}$ \\
\hline $\begin{array}{l}\text { Program management } \\
\text { and data analysis }\end{array}$ & $\$ 21,000$ first year & Salaries \\
\hline
\end{tabular}

aThe activities listed represent al ternative courses of action in several cases (see text). Therefore, total program costs are not given.

$b_{A}$ per well rather than a per site cost is given because the number of wells to be logged witl depend on site-specific conditions. 


\section{ECOSYSTEM QUALITY}

A. Rationale

B. Data Requirements and Avallability

C. Plan for the Acquisition of Data for the Assessment of Potential Environmental Impacts on Ecosystem Quality 

VII. ECOSYSTEM QUALITY

C. F. Bryan and J. P. Newman

The purpose of this section is to provide the rationale and plan for the assessment of potential environmental impacts on ecosystems from geopressured resource development in Louisiana.

Summary of Findings. The project area is divided into ten ecosystem types, based on vegetation, hydrology and water chemistry, which are then described in terms of the biota. Most of the geopressured prospect areas are in the wetland and aquatic ecosystems of the coastal zone. These areas are important for fisheries, fur production and recreation as well as mineral production. Since these ecosystems are dependent on daily and seasonal cycles of physical events, they will be sensitive to disruption caused by full-scale geopressured development. Access or pipeline canals directly change wetlands to open water and also disrupt natural hydrological and migratory patterns. Any subsidence in the wetlands due to geopressured fluid withdrawal will change vegetation characteristics or convert productive marsh to open water. Accidental brine spills in the coastal zone may destroy vegetation and animal life wherever contacted, but if the volumes are limited these ecosystems should quickiy recover.

Upland and Gulf of Mexico areas are less sensitive to subsidence and construction activities. The Gulf would also be less sensitive to brine spills; however, brine spills in upland areas may quickly run-off into aquatic systems. Natural upland vegetation would be slow to recover from a brine spill.

Based on ecosystem quality criteria, geopressured activity would have the least effects in already disrupted upland locations, moderate 
effects in the open Gulf except where support and ancillary facilities cross wetlands, and major effects in the wetlands of the coastal zone. Biological studies on south Louisiana emphasize taxonomic and distributional information on vertebrates and include some vegetational zone mapping. Ecological studies have been made on economically important species, however. Studies of non-economically important species and total communities are lacking in quality and quantity. In order to monitor possible effects of geopressured development at specific sites, plans are proposed for several types of studies. Important communities should be sampled through time. Intensive studies are therefore proposed for the pre-development, construction, and operation phases. Reactions of populations and communities to specific potential contaminants should also be measured using acute and chronic bioassays. To measure functional components of ecosystem quality, productivity estimates and tissue analyses are recormended. 


\section{A. RATIONALE}

\section{Introduction}

In general, impacts on ecosystems from geopressured resource development will vary in extent and significance depending on the geographical location of the activity. For example, a given amount of subsidence will greatly impact low lying areas and consequently have a greater impact on ecosystems in these areas. Therefore, the rationale for the plan proposed here is based on : 1) the classification of geopressured prospect areas into ecosystem types; 2) a consideration of potential impacts on each ecosystem type taken separately; 3 ) a consideration of the relative vulnerability of ecosystems to the proposed development activities; and 4) a consideration of the cumulative effects of large-scale development in the study area.

\section{Environmental Setting}

\section{a. Aquatic and Wetland Ecosystems}

The geopressured prospect areas identified in the resource assessment phase of Department of Energy research are largely located in coastal Louisiana (see figure VII-A-1). This area is characterized by highly diverse and productive aquatic and wetland ecosystems which could be significantly impacted by large-scale geopressured resource development. If all of the prospect areas located in these ecosystems were developed according to the activities described in Section III, a total of $10,900 \mathrm{~km}^{2}$ $\left(4200 \mathrm{mi}^{2}\right)$ would be impacted to some degree. The cumulative effects of development of this magnitude could be very destructive to these sensitive ecosystems.

Louisiana contains 50 per cent of the marshes and wetlands of the Atlantic and Gulf Coasts of the United States. The economic value of 


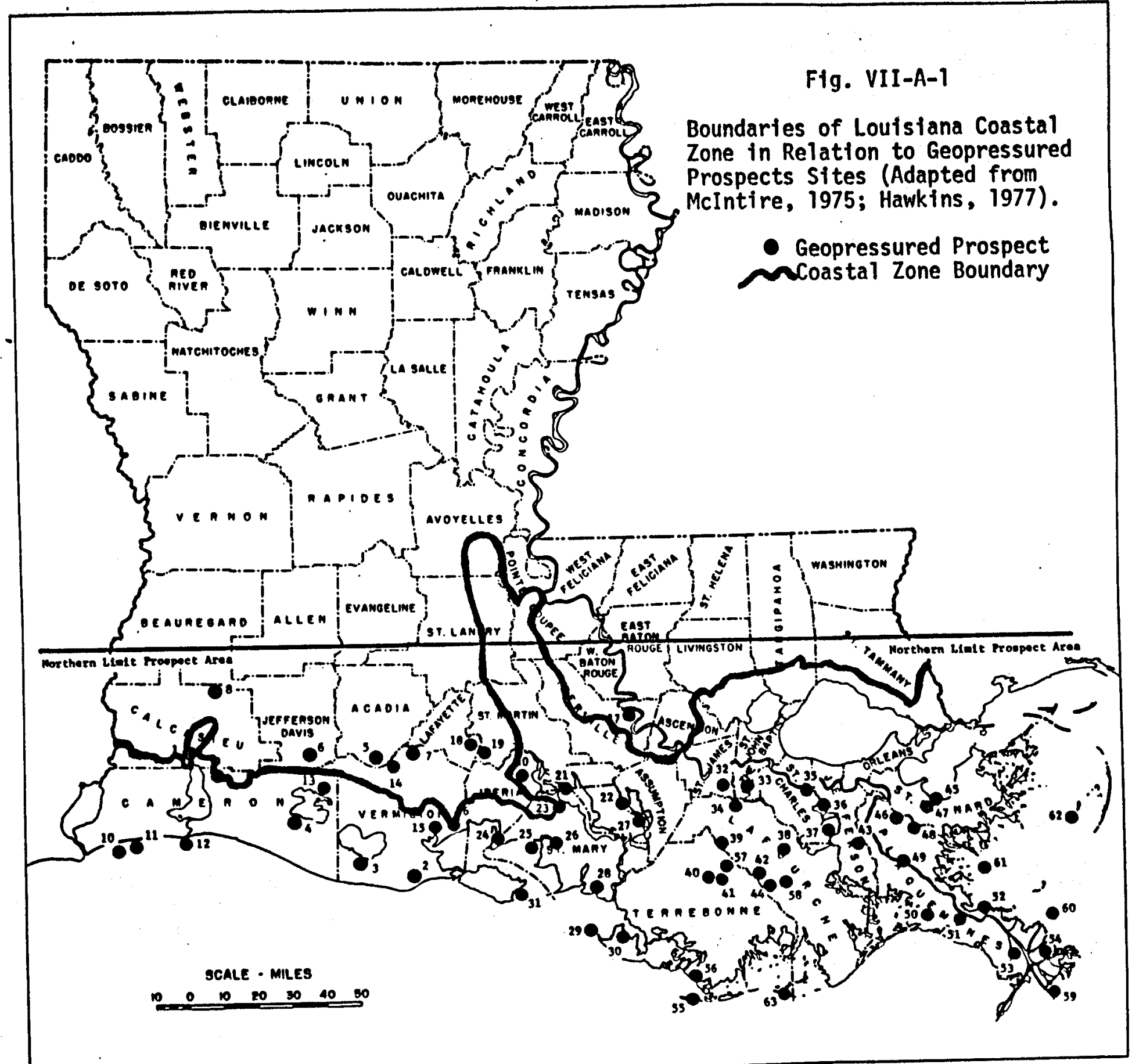


these wetlands derives from their use as habitat by sport and commercial fish, water fowl, and fur animals and in part from mineral production (see below and Section VIII). Less easily measured is the role of the wetlands and marshes as buffer zones between the Gulf and upland areas. These coastal ecosystems protect populated inland regions from erosion and storm surges from hurricanes and tropical disturbances. The marshes in turn assimilate and precipitate urban and industrial pollutants from upland areas.

The key to both the biological diversity and productivity of Louisiana wetlands is the unbroken intercommunication among many ecosystem types and the predictable cycles of physical events. Diversity is related to stability, predictability, rigor, and spatial heterogeneity of the environment (Pielou, 1975). Spatial heterogeneity is increased in the zone where two different habitats or ecosystems meet. Its effects are often referred to as the "edge effect". This zone is called an ecotone and species common to both areas are found in this transition zone. The classic example is the border between a forest and a field. In south Louisiana, the principal ecotone is the meeting of land and water in the marshes. Here productivity is maximized over a large area and much of this productivity is exported to the estuaries and Gulf. The animals in this complex ecotone are adapted to utilizing adjacent systems. Numerous organisms utilize the marshes, estuaries and Gulf during portions of their life cycle.

Al though the marshes and estuaries of Louisiana are in some ways rigorous, they are also fairly predictable. This is because the physical events driving the system are cyclic in nature. Near the Gulf, water level cycles daily with the tide. Seasonal cycles in water level from river discharges often override tidal effects. During highwater seasons, 
formerly dry land can become open water. These predictable events contribute to the productivity and diversity of the wetland ecosystems. Another important physical cycle is the seasonal variation in temperature. Temperature affects behavioral and physiological processes in organisms, as well as stratification patterns in lakes and other bodies of water. Productivity in Louisiana is high because all physiological processes such as feeding, assimilation, respiration, and development are accelerated by high, but not excessive, temperatures.

The wetlands are a complex network of open water--tributaries, distributaries, lakes, ponds, bays, canals, tidal passes--and intervening low lands which are flooded for all or part of the year. Because of the low elevation of the coastal region, small changes in water level can inundate or drain vast areas of wetlands. While this maximizes diversity and productivity, it makes classification of wetlands into ecosystem types very difficult. Since vegetative zones do not vary as much as hydrologic regimes, most of the definitions below rely heavily on vegetative characteristics. The classification system used here is drawn from several sources. Aquatic ecosystems are defined based on the system developed by the National Wetland Classification and Inventory Workshop (U.S. Dept. of Interior, 1975). Vegetated wetlands are classified separately: marshes are classed using Chabreck (1972, see Fig. VII-A-2); and cypress swamps and bottomland hardwoods, according to Newton (1972, see Fig. VII-A-3). Ecosystems occurring on higher ground within other wetland types are considered ecologically distinct (Noble, personal communication, 1977; see Fig. VII-A-4) and are therefore also classified separately. 


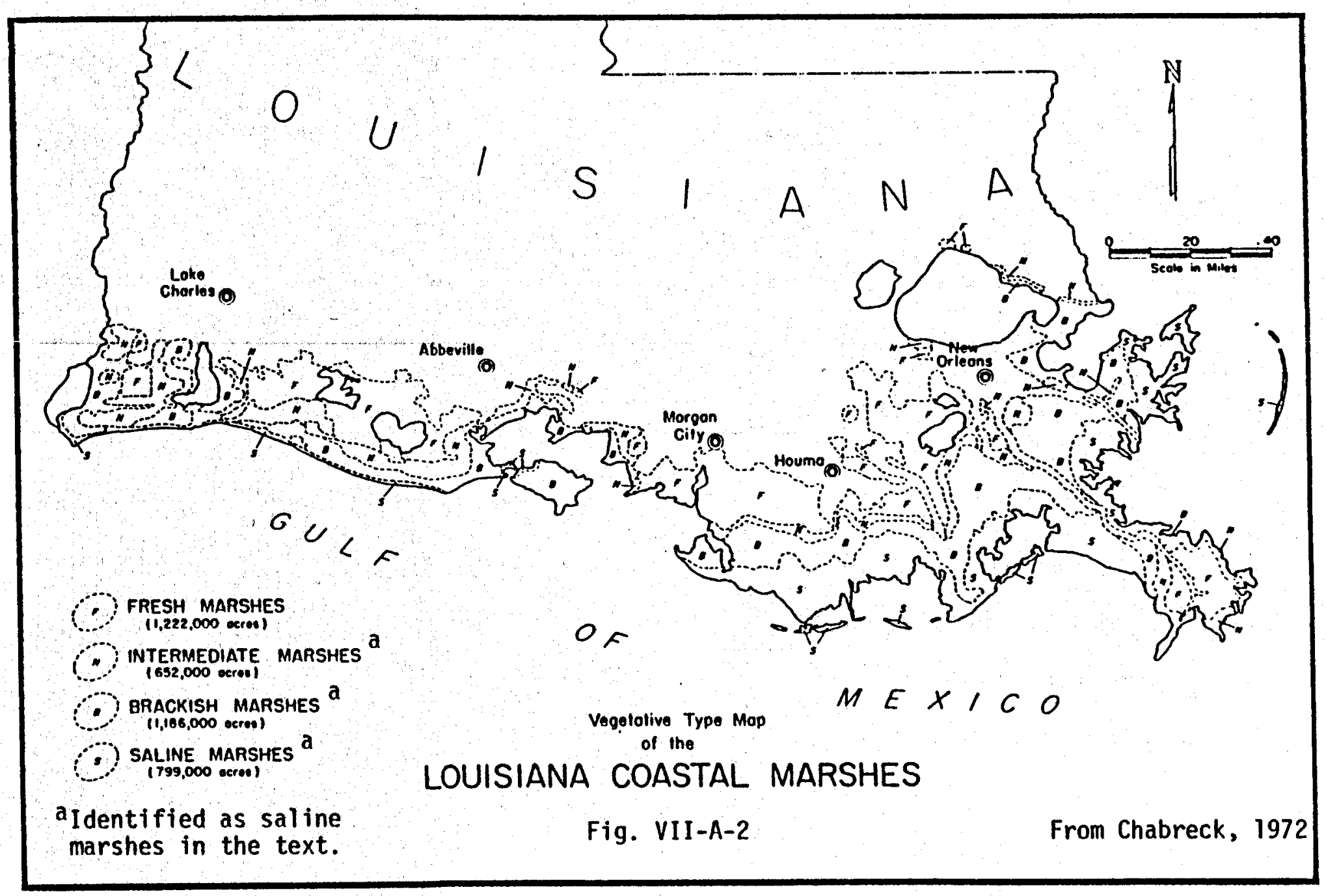




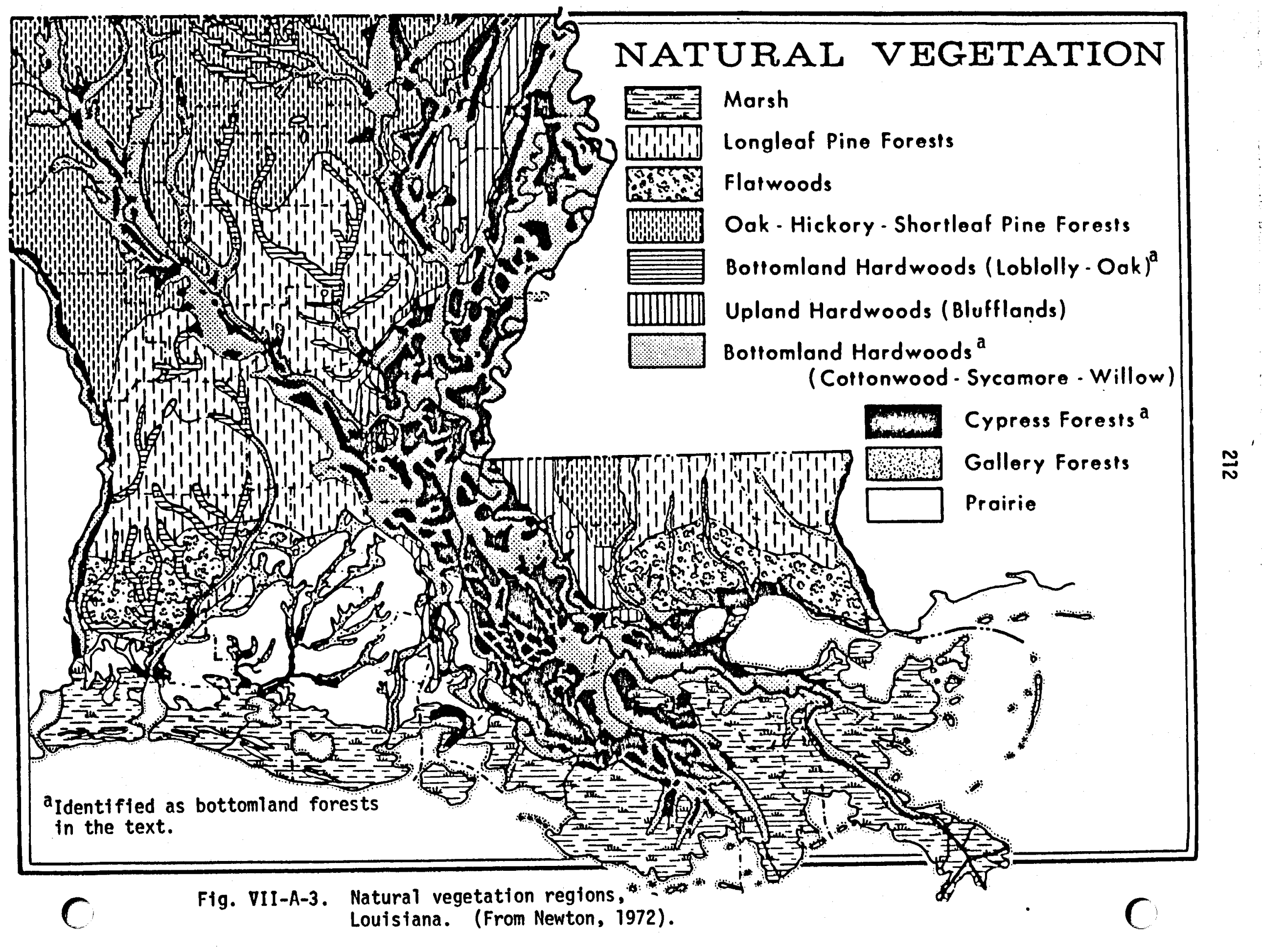




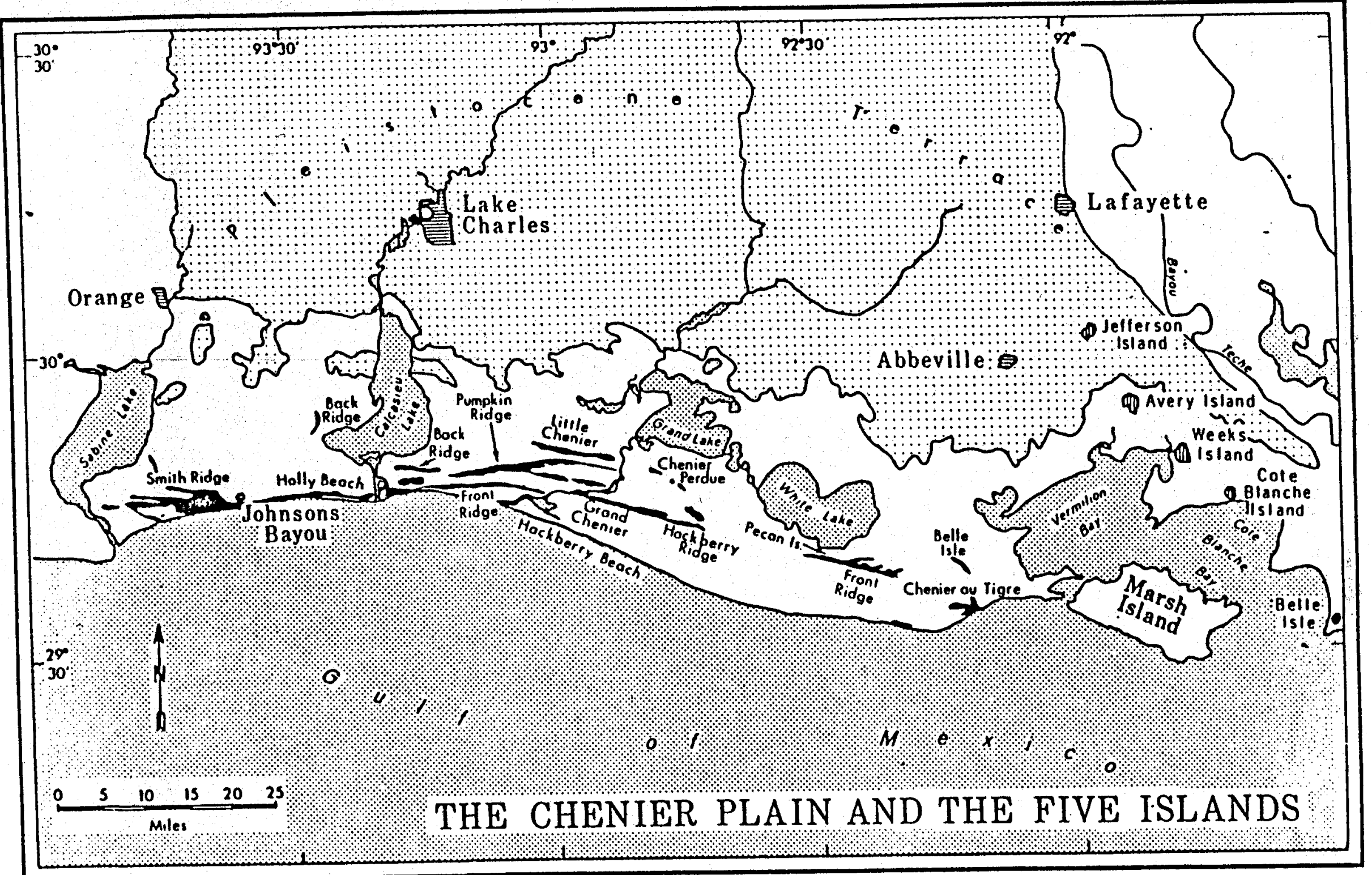

Fig. VII-A-4. Ridge ecosystems in southwestern Louisiana.

(From Newton, 1972). 


\section{b. Terrestrial Ecosystems}

Terrestrial ecosystems in the area of interest for. geopressured resource development occur primarily on the Pleistocene terrace. The Pleistocene terrace occupies the northern portion of the study area and is broken into two portions by the Mississippi river and its floodplain (Figure VII-A-5). The eastern portion of the terrace in Louisiana has no known geopressured resources.

The draining of these upland areas has been accelerated to make more land available for settlement and agriculture. Thus, most of the natural vegetation has been removed or modified. The natural vegetation, where it still exists, defines the prairie and the upland forest ecosystems.

The controlling factors in aquatic and wetland ecosystems are not applicable to terrestrial ecosystems. Riverine and tidal water cycles have little effect. With rapid and direct intracommunication among the many habitat types in these systems limited to only the larger, more mobile vertebrates, the systems are not dynamically interacting like the marsh ecosystems.

The ecosystem categories occurring within the area of interest for geopressured resource development are listed with a summary of major characteristics in Table VII-A-1. A brief description of each ecosystem type is given in Appendix A.

There are also a number of state wildlife management areas and wildlife refuges in the study area, as well as several federal wildife refuges. These are discussed in Section VIII, Socioeconomic and Cultural Considerations. The wildlife management areas and refuges include all of the 


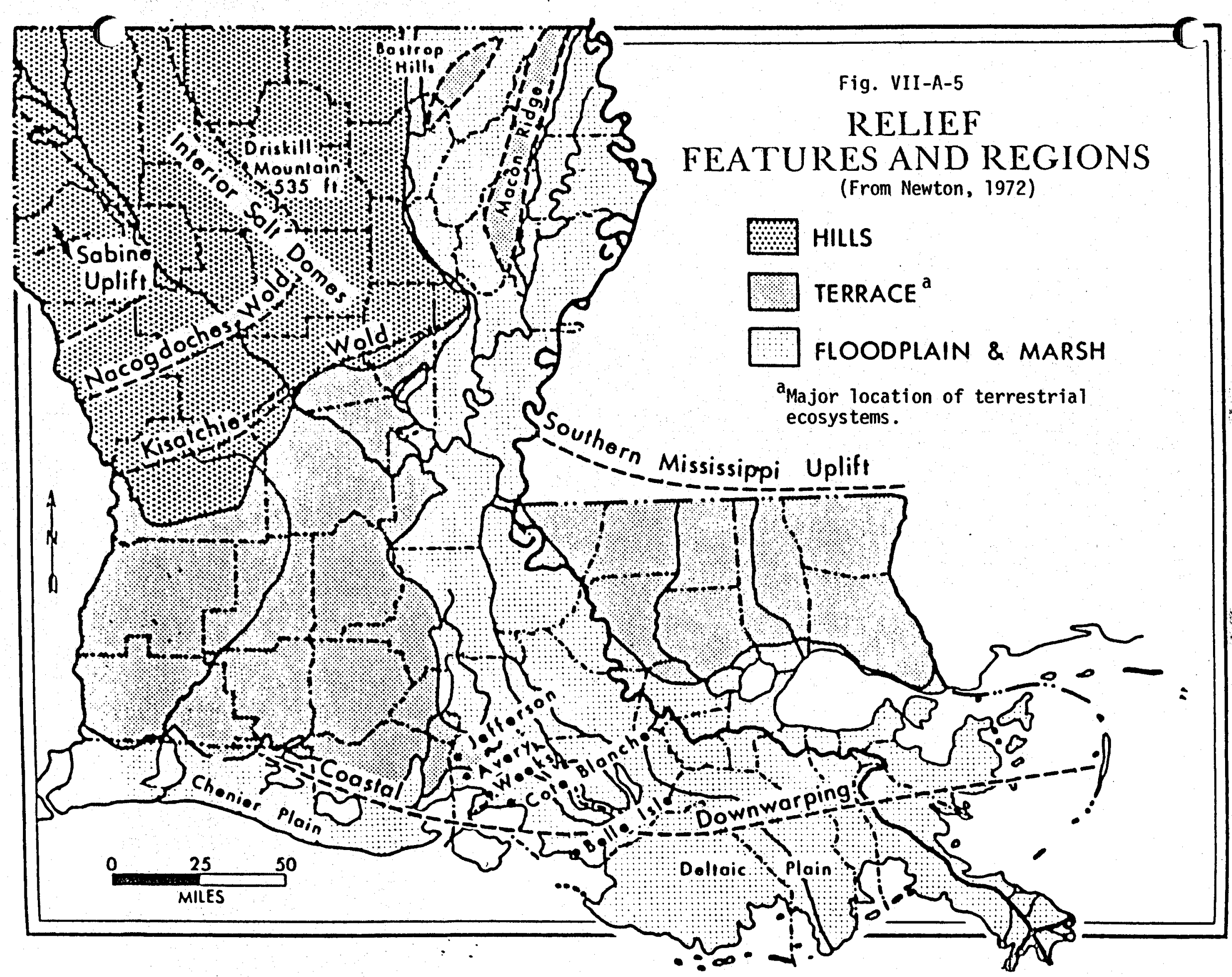


Table VII-A-1. Major characteristics of ecosystems in south Louisiana.

Marine Ecosystem.

Estuarine Ecosystem.

Fresh-water Ecosystem.

Saline Marsh Ecosystem.

Fresh Marsh Ecosystem.

Ridge Ecosystem.

Bottomland Forest.

Prairie Ecosystem.

Upland Forest Ecosystem.
Coastal open water system with unobstructed access to the open Gulf. The water regimes and water chemistry of this ecosystem are determined primarily by the ebb and flow of oceanic tides. Salinity levels vary from 10,000 to $35,000 \mathrm{mg} / 1$, depending on riverine discharge and distance offshore.

Coastal system, semi-enclosed by land, with open, partially obstructed, or sporadic access to the Gulf and with a measurable quantity of ocean-derived sait in the water. Salinities vary between 500 and $25,000 \mathrm{mg} / \mathrm{i}$.

Fresh-water ecosystems are divided into three subsystems: Palustrine, lacustrine, and riverine. These are all open fresh water areas where salinities are less than $500 \mathrm{mg} / 1$.

An emergent vegetated wetland system subject to tidal fluctuations of salt water greater than $500 \mathrm{mg} / 1$ salinity. This definition includes Chabreck's saline, brackish and intermediate marshes (Chabreck, 1972).

A herbaceous emergent vegetated wetland system which is subject to flooding with fresh water all or part of the year.

Isolated systems of higher ground within fresh or saline marsh ecosys tems. These areas include beaches, cheniers, natural and artificial levees, pleistocene islands, salt domes, spoil banks and Indian mounds.

Areas with woody vegetative cover flooded by fresh water all or part of the year. Two subsystems are recognized: cypress swamp forests and bottomland hardwood forests.

Terrestrial upland system which is naturally dominated by grasses.

Terrestrial systems located on the Pleistocene terrace and dominated by hardwood or pine trees. Ewo subsystems are recognized: the hardwood system and the flatwoods system. 
ecosystem types described above. Protected plant and animal species are also found in each ecosystem type. Table VII-A-2 1 ists endangered and threatened species in Louisiana.

c. Economic Setting

The ecosystems of south Louisiana have a high economic value because of their productivity of renewable resources and the presence of mineral resources. One method of comparing ecosystem types on the basis of the economic value of the renewable resources is to present the catch statistics for commercially harvested fish, shellfish, and furbearers. Fish and shellfish statistics are reported in a Department of Commerce publication (1977b). Recent furbearer statistics have been reported by 0 'Neil and Linscombe (1976). There are two major problems in assigning numerical values of this kind to ecosystem types, however. First, the statistics are not broken down into well defined areas. At most, harvests of each species are reported as "coastal" including offshore and inshore areas, and "inland" which includes the remainder of the state. Second, al though a resource is harvested in one ecosystem, its productivity and/or life cycle may be dependent on other ecosystem types. This is especially true of highiy migratory fish and shellfish. Gulf menhaden in 1976 yielded over $\$ 37$ million to the commercial fishing industry. All of this harvest was offshore marine; however, the entire early life history of this species is estuarine and saline marsh dependent. Brown and white shrimp undergo most of their growth in estuaries but are harvested primarily offshore.

It is possible to summarize the data in broad categories in order to give some idea of the relative economic importance of ecosystems. Freshwater fish (bowfin, buffalofish, carp, catfishes, bullheads, garfish, 
Table VII-A-2. Threatened and endangered species in Louisiana.

\section{PLANTS*}

Isoetes louisianensis

Amsonia glaberrina

Scutellaria thieretii

Bothriochola exaristata

Agalinis caddoensis

Ilex amelanchier

Tindera melissifolia

Sarracenia psittacina

Platanthera leucophaea

Platanthera integra

ANIMALS **

Lepidochelys kempii

Eretmochelys imbricata

Dermochelys coriacea

Alligator mississippiensis

Pelecanus occidentalis

Haliaeetus 1. Teucocephalus

Falco peregrinus anatum

Falco peregrinus tundrius

Campehilus principalis

Dendrocopus borealis

Vernivora bachmanii

Felis concotor cougar

Canis rufus

Trichechus mana tus quillwort

bluestar

skullcap

beardgrass

gerardia

sarvis holly

spice bush

parrot pitcherplant endangered

threatened

threatened

threatened

threatened

threatened

threatened

threatened

threatened

threatened
Atlantic Ridley turtle hawksbill turtle leatherback turtle American alligator brown pelican southern bald eagle American peregrin falcon arctic peregrin falcon ivory-billed woodpecker red-cockaded woodpecker Bachman's warbler eastern cougar red wolf West Indian manatee endangered endangered endangered threatened endangered endangered endangered endangered endangered endangered endangered endangered endangered endangered

* Proposed endangered or threatened (U.S. Department of Interior, 1975)

** Actual endangered or threatened (U.S. Department of Interior, 1977, 1978). 
paddlefish, shad, and fresh-water sheepshead) totaled nearly $\$ 4.1$ million in 1976. Fresh-water shellfish (crawfish, fresh-water shrimp, snapping turtles, frogs) totaled over $\$ 2.4$ million. Salt-water fish including estuarine and marine species (croaker, black drum, red drum, flounders, groupers, king whiting, menhaden, mullet, pompano, spotted sea trout, white sea trout, salt-water sheepshead, red snapper, Spanish macheral, spot and others) totaled $\$ 39.88 \mathrm{million}$; and salt-water shellfish (blue crabs, shrimp, oysters, squid, and sea turtles) totaled nearly $\$ 92$ million. Furbearers and alligator harvested in the 1974-5 season totaled $\$ 10.4$ million for aquatic dependant species (beaver, muskrat, nutria, racoon, mink, otter, bobcat, alligator) and only $\$ 105,000$ for non-aquatic species (opossum, coyote, red fox, and skunks).

In summary these figures show that most animal production harvested for human use is dependent on aquatic or wetland ecosystems. Total commercial value for these systems was over $\$ 148$ million for one year. Value of terrestrial animals totaled only $\$ 105,000$. The recreational value of all of the ecosystem types is also significant, although again, the wetland and aquatic ecosystems probably account for more sport catch than upl and ecosys tems.

\section{Potential Environmental Impacts}

Potential environmental impacts on ecosystems from geopressured resource development in the study area are discussed below, with particular attention to the relative vulnerability of ecosystem types to the activities and occurrences stemming from development activities. It should be noted that both direct and indirect impacts have been assessed, but the impacts arising from ancillary activities of development of the resource (i.e., industrialization and the like) are beyond the scope of this study. The 
identification of these potential impacts and their relative significance in the diverse environment of the study area is based on the proposed activities and resource characterization (see Section III) in view of the environmental setting of the study area, as described above. In addition, interviews with representatives of regulatory agencies, research and planning groups, and industries were used to identify impacts and assess their significance.

Particular attention has been given to the cumulative impact of large-scale geopressured resource development in Louisiana. This approach is consistent with the objective of this study; and is also clearly called for because of the uniquely high value, both cultural and commercial, of. the ecosystems of south Louisiana. Also, it has been demonstrated that these ecosystems are highly vulnerable to large-scale resource extraction-specifically oil and gas production.

In terms of the activities that take place during well field development, 011 and gas recovery and geopressured resource recovery are nearly identical. It is the cumulative impact of these practices, not those of the individual small operations, that create problems in terms of ecosystem quality (St. Amant, 1977; personal comunication, 1977; Herring, personal comunication, 1977; Smith, personal comunication, 1977). At the same time, the impacts that could result from features unique to geopressured resource recovery--e.g., subsidence due to the large volume of fluid withdrawal required for net energy recovery--are significant chiefly because of their cumulative effect.

\section{a. Subsidence}

Land subsidence due to geopressured fluid withdrawal would have significant adverse effects in the Louisiana coastal region. Much of the study 
area has very low elevations and relief and is therefore vulnerable to extensive inundation from any measurable amount of subsidence. Subsidence would also increase the area subject to periodic flooding from stream discharge and storm surge.

Land loss in the Louisiana coastal region is an on-going process resulting from natural subsidence and erosion, and the erosion and salt water intrusion that results from dredge and fill operations in marsh ecosystems. The rate of land loss in south Louisiana has been estimated at $50 \mathrm{~km}^{2}\left(20 \mathrm{mi}^{2}\right.$ ) per year (Craig, et. al., 1977; Templet, personal communication, 1977). Additional loss of the uniquely productive marsh ecosystems due to subsidence induced by the withdrawal of geopressured fluids, would accelerate the changes in biota already occurring in the wetlands. In general, marsh ecosystems are more productive than open water systems. Therefore, conversion of marsh to open water results in a net loss in biological productivity. Land loss due to subsidence is irreversible, and therefore of major concern (Templet, personal communication, 1977).

The effects of induced subsidence on biological assemblages are discussed below. The factors that contribute to the probability of subsidence occurring during geopressured resource development, as well as the legal implications of induced subsidence, are addressed in Section IV.

Marsh ecosystems are the most sensitive to both natural and induced subsidence because their structure and productivity are based on the juxtaposition and interaction of air and water. Vast areas are only a few centimeters above sea level. Subsidence in these ecosystems would alter the land/water ratio and reduce the edge effect--changes that would 
certainly diminish natural resource production. Since the system is based on detritus production from emergent vascular plants that are adapted to specific tidal regimes, when these plants are gradually lost, the energy and materials for higher trophic levels will be lost. Probably the first signs of lost productivity will be felt in peneaid shrimp production. Other important species such as crabs and sports and commercial fishes will be subsequentiy lost.

Induced subsidence in fresh-water marshes would probably harm freshwater aquatic species in a manner similar to that described for saline marshes. The fresh-water marshes are the prime nursery ground for freshwater vertebrates. Either permanent inundation or increased flooding due to subsidence would change plant species composition and reduce duck and geese populations in these areas.

Subsidence could indirectly affect open water habitats in fresh-water ecosystems through changes in hydrologic patterns in lakes and streams. If subsidence occurred in or near coastal freshwater lakes, for example, salt water could intrude from the Gulf and change the entire character of the water body. All aquatic organisms are to a greater or lesser degree permeable to the surrounding water medium. Most fresh-water organisms are not adapted to osmoregulate at salinities much above $500 \mathrm{ppm}$. Any saltwater intrusion will likely extirpate many species and disrupt existing community structure. Increasing the salinity in estuaries will have less drastic effects, but will also change the communities in the ecosystem.

The bottomland forest ecosystems are adapted to yearly or infrequent watering and dewatering. If the surrounding water level were higher and the area subjected to more persistent flooding, gradual changes in plant cormunity composition would occur, and the yearly cycle of detritus export would be altered. These changes would result in decreased aquatic 
productivity. Commercial and recreational fishes which spawn in these areas will be affected, as well as crawfishes which use flooded swamps for foraging.

Similarly, habitat loss in ridge ecosystems (such as cheniers, salt domes and beaches) due to land subsidence could occur. This effect would impact the migrating birds which use the ridge ecosystems as landfalls. Thus significant habitat loss in ridge ecosystems would have impacts over a much broader area than that directly affected by flooding or more permanent inundation.

The effects of subsidence on the biological assemblages of the upland terrestial ecosystems would be confined to areas that are already poorly drained. Marine ecosystems are permanentiy flooded so that subsidence would have little impact if the development of the geopressured field is far enough from land.

\section{b. Site Preparation and Construction}

Changes in water circulation and mixing patterns within wetland ecosystems result from the construction of access canals, roads, spoil banks, levees, and drilling pads. These changes in circulation could have significant adverse impacts on the biota of vegetated wetlands and adjacent open water systems.

Typically, canals are dredged in wetland areas to provide access to well sites for drilling rigs and other equipment and vehicles. These canals average $1.8-2.4$ meters $(6-8$ feet) in depth, and $15-18$ meters $(50-60$ feet) in width. Canals provide routes for salt water or freshwater intrusion and can alter mixing patterns within a system. Erosion due to wave action from boats using canals causes increased turbidity 
and land loss. The construction of roads, spoil banks, and the like, as well as draining areas for construction of drilling pads and structures would have similar effects.

Changes in salinity patterns due to construction of canals, drilling pads and the like will have effects on marsh and estuarine species similar to those described in connection with subsidence. Also, migratory routes for some species could be blocked. Increased turbidity, although a more temporary phenomenon, reduces the depth of effective photosynthesis and has an effect on water quality parameters (and thus aquatic species) such as dissolved oxygen content and temperature.

There is evidence that dredging and construction activities in the coastal region has already had a deleterius effect on the productive wetland ecosystems (Adams, et. a1., 1976; Byrne, et. a1., 1976; Stone, . et. al., 1977; St. Amant, personal cumunication, 1977). The coastal area is criss-crossed by canals for various purposes. In the Barataria Basin in the eastern portion of the study area, canals cover $155 \mathrm{~km}^{2}$ $\left(60 \mathrm{mi}^{2}\right)$ or 2 per cent of the total Basin area. Thirty-five per cent of these canals are rig access, pipeline and oil field navigation canals (Byrne, et. al., 1976). Oil field pipelines and canals in Barataria Basin are shown in Figure VII-A-6. Typical canal networks for other activities are shown in Figure VII-A-7.

Dr. Lyle St. Amant, Assistant Secretary of the Louisiana Department of Wildlife and Fisheries has suggested alternative practices in hydrocarbon production to minimize surface activity, and thereby surface disruption, in wetland ecosystems. Specifically, he recommends the use of directional drilling to reduce surface effects of drilling activities, and the use of helicopters to construct power lines and the like. It has 


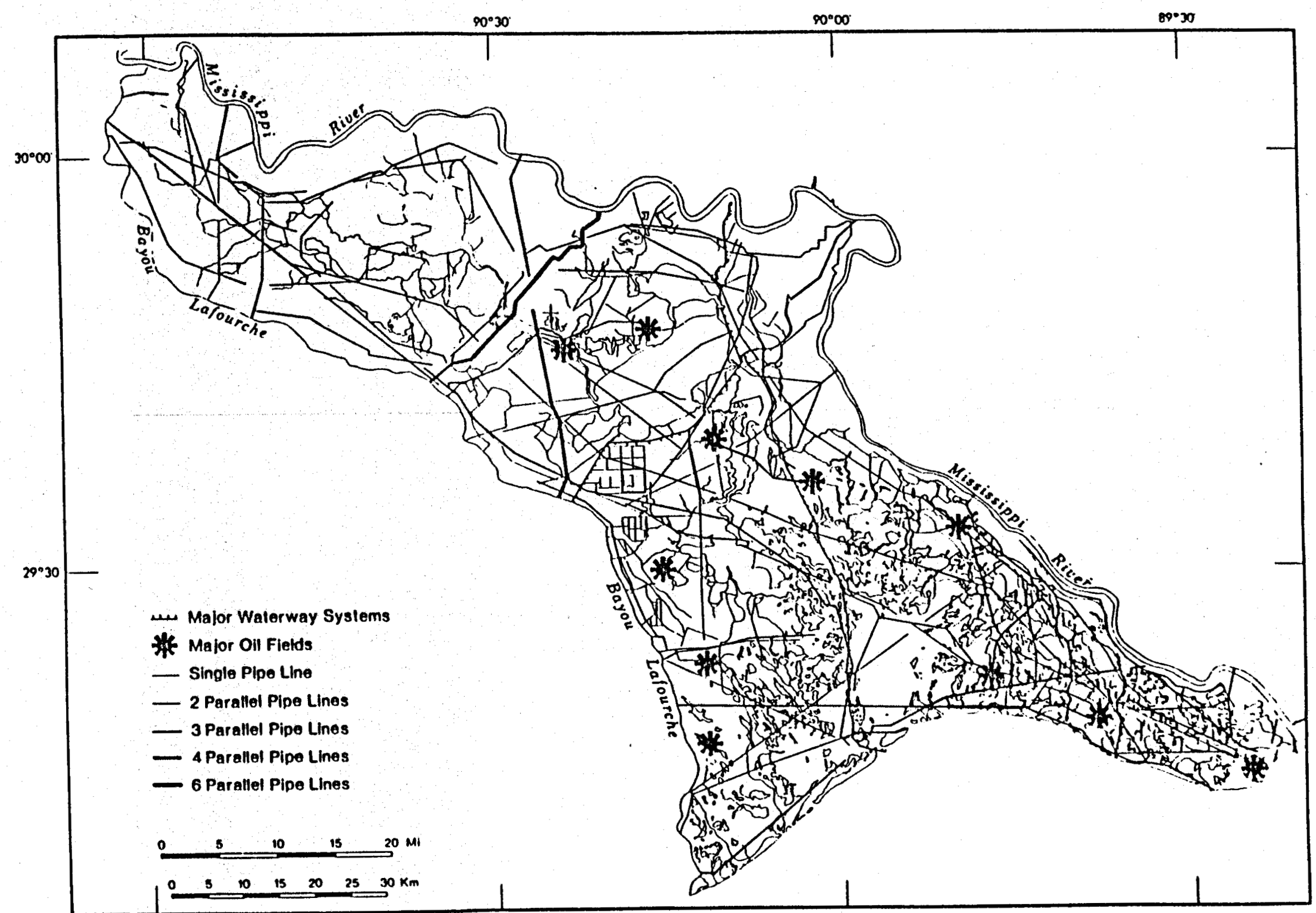

Fig. VII-A-6. Major waterways, pipelines, and oil fields within Barataria Basin. (From Adams, et al., 1976). 

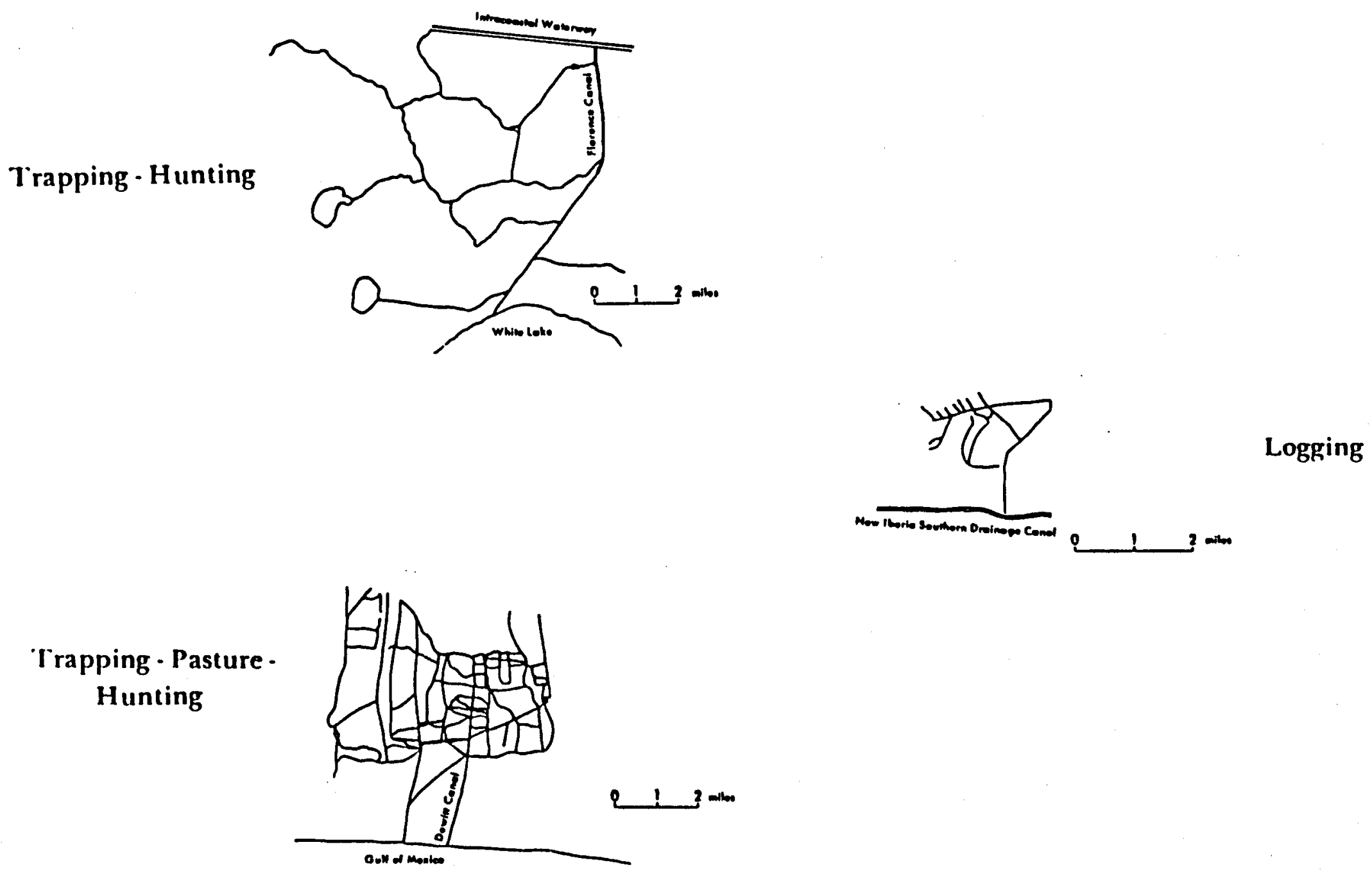

Fig. V11-A-7. Typical canal networks, Louisiana Coastal Region. (From Newton, 1972). 
been Dr. St. Amant's experience that the cumulative effect of dredging and construction for oil and gas production in the wetlands areas has presented serious problems with respect to the productive fisheries in those areas, and will also be problematic in the course of full-scale geopressured resource development (St. Amant, personal communication, 1977).

\section{c. Fluid Disposal}

The description of the proposed activities presented in Section III specifies two methods of spent fluid disposal: subsurface injection; and, alternatively, surface disposal into the Gulf. Spent fluids could be transported for disposal into the Gulf either in an open, lined ditch or by pipeline.

Problem areas with respect to subsurface disposal of fluids are potential contamination of fresh ground water, and the possibility that spent geopressured brines could bleed to the surface along fault lines or breach abandoned oil and gas wells (Bates, personal communication, 1977). Ground-water contamination is discussed in Section VI. If brines bled to the surface, the impacts on the biota in the study area would be similar to those resulting from accidental brine spills. These are discussed in the following section.

Surface disposal of spent fluids into the Gulf may be environmentally feasible if water quality criteria can be met. Aquatic spectes will be sensitive to the following fluid parameters: temperature, total dissolved solids, absence of dissolved oxygen, possible trace amounts of $\mathrm{H}_{2} \mathrm{~S}$ and $\mathrm{NH}_{3}$, and possible trace amounts of toxic metal ions. If spent fluids are transported in open ditch systems, additional areas of concern are addition of salt to soils adjacent to the ditch and atmospheric release of possible trace amounts of $\mathrm{H}_{2} \mathrm{~S}$ and $\mathrm{NH}_{3}$. Both of these occurr- 
ences could result in destruction of vegetation. If disposal ditches intersect open water areas, there is additional possibility for contamination and obstruction of water circulation and migratory routes. These factors could well preclude the use of open ditch systems in the Louisiana coastal region.

\section{d. Accidental Brine Spills}

Accidental spills of geopressured brines--either during production, collection, temporary surface storage, transportation, or disposal--will have adverse impacts on the biota within the immediate vicinity of the spill for a relatively brief period. In certain ecosystems, however, the area impacted could be considerable in extent with longer-term impacts. For example, estuarine fauna and flora are adapted to withstand rapid changes in environmental parameters such as temperature and salinity. However, the estuarine ecosystem functions as a nutrient sink, trapping and storing nitrogen and phosphorus compounds in the sediments of the estuary. The same physical processes involved in this function would also trap and concentrate toxic ions contained in geopressured fluids, creating persistent detrimental effects.

Similarly, spills of brines in the watersheds of fresh-water ecosystems could also have long-term effects as toxic ions accrue in and recycie from the sediments of fresh-water systems. In addition, freshwater organisms are osmotically adapted to low salinities and therefore sensitive to any waste brines. The destruction of fresh-water flora and fauna from an accidental brine spill could extend downstream until dilution would bring salinities into sublethal range.

Brine spillage in saline marshes would $k 111$ vegetation in the area of the spill, but, because saline marshes are frequently flushed by 
tidewaters, this ecosystem would recover more quickly than other less dynamic ecosystems. Brine release in fresh-water marshes would destroy the indigenous biota and thereby make the area unattractive to waterfowl. Brines would tend to remain longer in the fresh-water marsh system than saline marshes because of less flushing from local flooding. The period of recovery of the fresh-water marshes would depend on the height and degree of local flooding, as well as the amount of spillage.

Brines, if spilled in bottomland forests, would destroy vegetation in a limited area but could be transported into surrounding waterways during high water periods or by runoff. Recovery of mature forests would be very slow. In the upland, terrestrial ecosystems, brine spills would be more easily contained than in wetland ecosystems. Adverse impacts would be confined to the area in the immediate vicinity of the spill.

\section{e. Air Quality Impacts}

The discussion below is limited to the effects of air quality degredation on the biota of the study area. General impacts from the atmospheric release of toxic substances during geopressured resource development are addressed in Section V. Air quality impacts on biota are not considered as significant as the impacts discussed above. Gaseous emissions are expected to disperse more rapidly than liquid effluents. Also, the amounts of atmospheric emissions that could be released, either during normal operation or accidentally, will be very small in comparison to liquid effiuents.

The gaseous emissions of concern in terms of their effects on biota are: (1) cooling tower exhaust--air, nearly saturated with water and containing corrosion inhibitors such as silicates; and (2) the main condenser purge stream--the noncondensibles from the main condenser 
(methane, $\mathrm{CO}_{2}$ and possible trace amounts of $\mathrm{H}_{2} \mathrm{~S}$ and $\mathrm{NH}_{3}$ ) and water vapor (Wilson, et. a1., 1977). Drift deposition of the cooling tower exhaust could harm vegetation in the vicinity because of the sodium and chloride ions. The main condenser purge stream is routinely flared. If the geopressured fluids contain significant amounts of $\mathrm{H}_{2} \mathrm{~S}$ or $\mathrm{NH}_{3}$, small amounts of sulfur oxides or nitrogen oxides will be released to the atmosphere, with deletorious effects on vegetation.

The vegetation of upland, terrestrial ecosystems is more sensitive and less resilient to airborne pollutants than the vegetation in wetland ecosystems. This is due generally to the more constant edaphic conditions that exist in upland ecosystems. For example, sulfide air pollution, which in the marsh ecosystem would be quickly assimilated and/or precipitated, would either directly damage upland vegetation; or, if washed by rain into the soil, would tend to effect long-term changes in normal plant succession.

\section{f. Other Impacts}

Wetland ecosystem biota could be adversely affected because of temperature changes in their habitat (St. Amant, personal communication, 1977). These changes would arise sporadically because of brine spills, and the like, but would occur routinely as a result of the transportation of brines during all phases of the resource development. In the 011 and gas industry, collection pipelines, if buried at all, are usually buried at very shallow depths in wetland areas. Frequently, these pipelines are laid directly on the surface and are covered by normal processes of siltation. With brine temperatures expected to average $98^{\circ} \mathrm{C}\left(209^{\circ} \mathrm{F}\right)$ at the wellhead, the temperature of the water and soil surrounding these 
pipelines could be raised in the immediate vicintty. The cumulative impact of these changes due to full-scale development of geopressured resources could be warming of water and soils over large areas. Temperatures in south Louisiana waters and soils during summer months are very high and already near the lethal limit for many species. If significant heat reaches the surrounding water and soils from pipelines, the endemic communities could be disrupted. Also, migratory aquatic animals might avoid the waterway simply because of the heat or subsequent loss of oxygen from the water column. 
U 


\section{B. DATA REQUIREMENTS AND AVAILABILITY}

\section{Data Requirements}

Data requirements for the long-term assessment of potential impacts on ecosystem quality are summarized in Table VII-B-1. The list is essentially limited to data requirements with respect to the biota in the study area, and to ecosystem functions. Data on air and water quality are, of course, required for the assessment. These are treated in detail in Sections $V$ and $V I$, respectively.

The rationale behind the types of studies outlined is the need to determine if environmental degredation is occurring due to geopressured resource development and which aspect of the development is causing the degredation. Three classes of studies are outlined in Table VII-B-1: biological surveys, biological assays, and special studies. All of the biological studies should be responsive to the findings of the other subprograms, and particularly to inputs from the air and water quality programs. The surveys provide basic data on the populations of plants and animals in the study area. Acquisition of this data is extremely important to the overall assessment. Communities of plants and animals are sensitive indicators of their environmental conditions and therefore must be precisely identified. Furthermore, a number of species in the study area are economically important or are rare and endangered. If sampling is conducted through time and coordinated with development activities, any harmful biological impacts can be measured.

A11 ten ecosystem types described in Section VII-A-2 fit together within a complex system of interacting parts. Marsh and adjacent estuary are interacting, while bottomland hardwoods are in close association with 
Table VII-B-1. Data requirements for the assessment of impacts on ecosystems.
OFFSHORE
COASTAL
UPLAND

\begin{tabular}{|c|c|c|c|}
\hline $\begin{array}{l}\text { BIOLOGICAL } \\
\text { SURVEY }\end{array}$ & $\begin{array}{l}\text { Phytoplankton } \\
\text { Zooplankton } \\
\text { Macrobenthos } \\
\text { Fish } \\
\text { Water quality } \\
\text { Sediment physicochemistry }\end{array}$ & $\begin{array}{l}\text { Fish } \\
\text { Macrobenthos } \\
\text { Meiobenthos } \\
\text { Phytoplankton } \\
\text { Zooplankton } \\
\text { Emergent vegetation } \\
\text { Terrestrial vertebrates }\end{array}$ & $\begin{array}{l}\text { Fish } \\
\text { Macrobenthos } \\
\text { Phytoplankton } \\
\text { Zooplankton } \\
\text { Terrestrial vegetation } \\
\text { Terrestrial vertebrates }\end{array}$ \\
\hline & & $\begin{array}{l}\text { Water Quality } \\
\text { Sediment physicochemistry } \\
\text { Soil physicochemistry }\end{array}$ & $\begin{array}{l}\text { Water Quality } \\
\text { Sediment physicochemistry } \\
\text { Soil physicochemistry }\end{array}$ \\
\hline $\begin{array}{l}\text { BIOLOGICAL } \\
\text { ASSAYS }\end{array}$ & $\begin{array}{l}\text { Effects of: } \\
\text { 1)specific lons and } \\
\text { compounds in brine } \\
\text { streams } \\
\text { 2) heat } \\
\text { 3)dredging } \\
\text { on selected fish and } \\
\text { macroinvertebrates }\end{array}$ & $\begin{array}{l}\text { Effects of: } \\
\text { 1) specific ions and } \\
\text { compounds in brine } \\
\text { streams } \\
\text { 2) heat } \\
\text { 3)dredging } \\
\text { 4)atmospheric emissions } \\
\text { on selected fish, } \\
\text { emergent plants and } \\
\text { macroinvertebrates }\end{array}$ & $\begin{array}{l}\text { Effects of: } \\
\text { 1) specific ions and } \\
\text { compounds in brine } \\
\text { streams } \\
\text { 2) heat } \\
\text { 3)atmospheric } \\
\text { on selected fish, invertebrates, } \\
\text { and terrestrial vegetation }\end{array}$ \\
\hline $\begin{array}{l}\text { SPECIAL } \\
\text { STUDIES }\end{array}$ & $\begin{array}{l}\text { Analysis of tissues } \\
\text { (fish, birds, inverts.) } \\
\text { Primary Productivity } \\
\text { (phytoplankton) }\end{array}$ & $\begin{array}{l}\text { Analysis of tissues } \\
\text { (fish, birds, mammals, } \\
\text { inverts. and plants) } \\
\text { Primary Productivity } \\
\text { (emergent vascular } \\
\text { plants and phytoplankton) }\end{array}$ & $\begin{array}{l}\text { Analysis of tissues } \\
\text { (fish, birds, mammals, } \\
\text { inverts. and plants) } \\
\text { Primary Productivity } \\
\text { (terrestrial vegetation } \\
\text { and phytoplankton) }\end{array}$ \\
\hline
\end{tabular}


fresh-water ecosystems. And, of course, the marine environment receives runoff from inland systems. Any single geopressured well field will probably encompass two or more ecosystem types. The communities of plants and animals in each ecosystem, the development activities appropriate in that area, and the actual amount of surface area required for those activities will be highly variable depending upon the sites selected. Therefore, three somewhat different plans for studying the ecosystems potentially influenced by geopressured development are presented here. Offshore development will impact the marine environment and all systems which pipelines and transmission lines cross. Coastal development will impact saline marsh, estuaries and ridge ecosystems. Inland development will impact bottomland and upland forests and fresh-water systems.

In each of these three regions, different communities are important. Fish communities are important everywhere for their recreational and economic value. Some macrobenthic invertebrates, such as oysters, are commercially important; others provide food for fish that are harvested. Macrobenthic invertebrates are generally non-migratory. In offshore areas which are entirely open water, planktonic communities should also be studied. In the coastal region, studies should include fish, macroinvertebrates, meiobenthos, zooplankton, emergent vegetation, and terrestrial vertebrates. In upland areas, communities of interest include fish, macrobenthos, phytoplankton, terrestrial vegetation, and terrestrial vertebrates. In all areas, measurements of water chemistry and soil and/or sediment physicochemistry should be made.

Biological assays are studies to determine the acute or chronic toxicity of pollutants to plants and animals. Possible pollutants of interest include 
$\mathrm{H}_{2} \mathrm{~S}, \mathrm{NH}_{3}, \mathrm{SO}_{x}, \mathrm{NO}_{x}$, radon, boron, and other metals. Results from the chemical analysis of geopressured fluids specific to each well field may enlarge this list or eliminate some components from it. The effects of heat on organisms should also be studied.

Special studies are all studies of geopressured development not in the above two classes. These studies should be related to functional components of the ecosystems such as primary and secondary productivity, nutrient and ion uptake, bioconcentration and cycling, energy flow, and physiological processes. There are endless possibilities for research in this area, but we have budgeted for only two types of studies. Tissue analysis of plants and animals will determine if specific ions and compounds from geopressured development are being accumulated in the biota and/or contaminating food sources. Primary productivity measurements of phytoplankton and emergent and terrestrial plants and crops will show if photosynthetic rates are being affected by development.

\section{Data Availability}

Previous biological studies in south Louisiana are, of course, valuable in assessing potential geopressured impacts, although they were not designed for this purpose. The large number of published and unpublished studies range from narrow to broad in scope. The most valuable studies are those which concern entire communities of the biota. However, there are very few studies of this type and these are usually geographically, temporally or taxonomically limited. Further limitations of these studies are methodological inadequacies and lack of functional components.

Depending on the site, there may be little or extensive biological data avallable. The annotated bibilography which follows lists those 
studies which either are holistic in approach or have extensive bibiliographies which can be used to obtain additional data. Other sources of data include governmental agencies such as U.S. Fish and Wildlife Service, U.S. Environmental Protection Agency, U.S. Army Corps of Engineers, U. S. Geological Survey, U.S. Soil Conservation Service, Louisiana Department of Wildlife and Fisheries, Louisiana Department of Conservation, Louisiana State Planning Office; and thesis and reports of Louisiana college and university students and faculty.

Maps. Maps are useful in conceptualizing geographic variation in vegetative zones, soil types and other features as preparation for field work.

Burk and Associates, Inc., 1976, Louisiana coastal vegetation: Louisiana State Planning Office, Baton Rouge, La.

Burk and Associates, Inc., 1976, Unique ecological features of the Louisiana coast: Louisiana State Planning Office, Baton Rouge, La.

Chabreck, R. H.; Joanen; T., and Palmisano, A. W., 1968, Vegetative type map of the Louisiana coastal marshes: La Wildiife and Fisheries Commission, New Orleans, La.

Lytle, S. A., and Sturgis, M. B., 1962, General soil areas and associated soil series groups of Louisiana: Agricultural Experiment Station, Louisiana State University, Baton Rouge, La.

Bibliographies and Reviews. This group of references is potentially valuable primarily because they conta in lists of additional references and/or summarize existing data. Baker and Beckert's (1972) bibliography contains 983 references on the Louisiana coastal zone. A valuable annotated bibliography is found in Gustavson and McGraw (1977) and a fairly complete review of coastal biology in Gosselink (1977). An overview of these references shows several major gaps in data for south Louisiana. First, previous studies are very limited in scope. Either a single small 
taxon was studied or only one aspect of a taxon was studied. Second, most studies are geographically limited. Large areas of the Louisiana coast have never been scientifically studied. Third, many studies are methodologically inadequate. Either the studies were not quantitative or the gear used was deficient.

Bahr, L. M.; and Hebrard, J. J., 1976, Chenier Plain: biological characterization: Louisiana State University Center for Wetland Resources, Baton Rouge, La., Sea Grant Publ. No. LSU-SG-TDA-76(t).

Baker, L.; and Beckert, H., 1972, A partial bibliography of the ecology and biology of the coast of the Gulf of Mexico with emphasis on the Louisiana coast: Univ. of Southwestern Louisiana, Lafayette, La., Research Series No. 15, Biology.

U.S. Department of the Interior, Bureau of Land Management, 1974, Environmental and socio-economic baseline data on the Gulf of Mexico coastal zone and outer continental shelf - current and recent research on environmental processes and conditions in the Gulf of Mexico region, vol. 1, 2, and 3: U.S. Government Printing Office, Washington, D. C.

Coastal Environments, Inc., Baton Rouge, La., 1976, An environmental assessment of proposed geothermal well testing in the Tigre Lagoon oil field, Vermilion Parish, Louisiana: for Givision of Geothermal Energy, Department of Energy, Washington, D. C.

Gosselink, J. G., 1978, Ecological characterization of the Chenier Plain: Vol. I, Wildlife populations and habitats: Center for Wetland Resources, Louisiana State University, Baton Rouge, La., in preparation.

Gustavson, T. C.; and McGraw, M. M., 1977, Ecological implications of geopressured-geothermal energy development, Texas-Louisiana Gulf Coast region: the energy resource, Interim Project Report: Bureau of Economic Geology, Austin, Texas.

Gutherz, E. J.; Russell, G. M.; Serra, A. F.; and Rohr, B. A., 1975, Synops is of the north Gulf of Mexico industrial and foodfish industries: Mar. Fish. Rev., 38(7):1-11.

Shampine, W. J., 1971, Chemical, biological, and physical data for the major lakes and reservoirs in Louisiana, Basic Records Report No. 5: U.S. Department of the Interior, Geological Survey, Water Resources Division; Louisiana District; and Louisiana Department of Public Works, Baton Rouge, La. 
U.S. Army Corps of Engineers, 1975, Inventory of basic environmental data, New Orleans-Baton Rouge metropolitan area: U.S. Army Engineer Topographic Laboratories, Washington, D.C.

U.S. Army Corps of Engineers, 1973, Inventory of basic environmental data, South Louisiana: U.S. Army Engineer Topographic Laboratories, Washington, D.C.

U.S. Corps of Engineers, 1973, Inventory of basic environmental data, South Louisiana, Mermentau River Bas in to Chandeleur Sound, with special emphasis on the Atchafalaya Basin: U.S. Army Engineer Topographic Laboratories, Washington, D.C.

Aquatic and Wetland Studies. Because Louisiana wetland and aquatic habitats are unique in the United States in terms of extent and biological productivity, most biological studies in Louisiana are concerned with these ecosystems. Studies included in the list below range from comprehensive studies covering large areas (Perret, 1971; Bryan et al. 1974,1975,1976; Chabreck, 1972; Palmisano, 1970; and Gosselink et al. 1976) to more limited studies covering small areas (Hood, 1970; Reese and Thieret, 1966). Other types of studies are those which compile fisheries statistics (U.S. Dept. of Commerce, 1974, 1976); those which list taxa and/or discuss their ecology (Douglas, 1974; Lowery, 1974; Thieret, 1972); those which are proceedings of symposia (Chabreck, 1973; Newsom; 1968).

Adkins, G.; and Bowmen, P., 1976, A study of the fauna in dredged canals of coastal Louisiana: Louisiana Wildlife and Fisheries Commission, Technical Bulletin, No. 18, New Orleans, Louisiana.

Bryan, C. F.; Truesdale, F. M.; Sabins, D. S.; and Demas, C. R., 1974, 1975, A limnological survey of the Atchafalaya Basin: Annual Reports, Louisiana Cooperative Fishery Research Unit, School of Forestry and Wildlife Management, Louisiana State University, Baton Rouge, La.

Bryan, C. F.; DeMont, D. J.; Sabins, D. S.; and Newman, J. P., Jr., 1976, A limnological survey of the Atchafalaya Basin: Annual Report, Louisiana Cooperative Fishery Research Unit, School of Forestry and Wildlife Management, Louisiana State University, Baton Rouge, La. 
Chabreck, R. H., ed., 1973, Proceedings of the Second Coastal Marsh and Estuary Management Symposium: Division of Continuing Education, Louisiana State University, Baton Rouge, La.

Chabreck, R. H., 1972, Vegetation, water and soil characteristics of the Louisiana coastal region: Agricultural Experimental Station, Bulletin No. 664, Louisiana State University, Baton Rouge, La.

Conner, W. H.; and Day, J. W., Jr., 1976, Productivity and composition of a baldcypress-water tupelo site and a bottomland hardwood site in a Louisiana swamp: Amer. Jour. Bot. 63(10):1354-1364.

Conner, W. H.; and Day, J. W., Jr., 1976, Productivity and composition of a freshwater swamp in Louisiana: Center for Wetland Resources, Louisiana State University, Baton Rouge, La.

Douglas, N. H., 1974, Freshwater fishes of Louisiana: Claitor Publishing Division, Baton Rouge, Louisiana.

Dunhan, F., A study of conmercially important estuarine-dependent industrial fishes: Louisiana Wildlife and Fisheries Commission, Technical Bulletin No. 4, Baton Rouge, La.

Gosselink, J. G.; Miller, R. R.; Hood, M.; and Bahr, L. M., Jr., eds., 1976, Louisiana Offshore Oil Port environmental baseline study: LOOP, Inc., New Orleans, La.

Herke, W. H., 1971, Use of natural and semi impounded Louisiana tidal marshes as nurseries for fish and crustaceans: Unpublished Ph.D. diss., Louisiana State University, Baton Rouge, La.

Hood, M. A., 1970, A bacterial study of an estuarine environment: Barataria Bay: Unpublished thesis, Louisiana State University, Baton Rouge, La.

Juneau, C., 1975, An inventory and study of the Vermilion Bay-Atchafalaya Bay estuarine complex: Louisiana Wildlife and Fisheries Comission Technical Bulletin No. 13, Baton Rouge, La.

Louisiana Cooperative Wildlife Unit, Final Report, 1977, Colonial sea and wading bird survey: U.S. Fish and Wildlife Service, Contract No. 14-16-0008-1187.

Lowery, G. H., Jr., 1974, Louisiana birds, Third Edition: Louisiana State University Press, Baton Rouge, La.

Newsom, J. D., ed., 1968, Proceedings of the First Marsh and Estuary Management Symposium, Division of Continuing Education, Louisiana State University, Baton Rouge, La.

Palmisano, A. W., 1970, Plant community-soil relationships in Louisiana coastal marshes: Unpubl. Ph.D. diss., Louisiana State University, Baton Rouge, La. 
Perret, W. S., 1971, Cooperative Gulf of Mexico estuarine inventory and study, Louisiana, Phase IV, Biology: Louisiana Wildlife and Fisheries Commission, Baton Rouge, La.

Reese, W. D., and Thieret, J. W., 1966, Botanical study of the Five Islands of Louisiana: Castanea, Vol. 31: 251-277.

Thieret, J. W., 1972, Aquatic and marsh plants of Louisiana: a checklist: Louisiana Soc. Hort: Res., Vo1. 13: 1-46.

U.S. Army Corps of Engineers, 1975, Environmental inventory and impact evaluation of maintenance dredging of the Sabine-Neches Waterway:

U.S. Army Corps of Engineers, Dist., Galveston, Texas.

U.S. Department of Agriculture, Soil Conservation Service, 1976, Guif Coast wetlands handbook: U.S. Dept. Agriculture, Alexandria, La.

U.S. Department of Commerce, National Marine Fisheries Service, Gulf Coast shrimp data, Annual Sumaries 1965-1975, 1976.

U.S. Department of Cormerce, National Marine Fisheries Service, Fishery Statistics of the United States, 1970-1973, Statistical Digest Nos. $64,65,66$, and 67 .

Terrestrial Studies. These references are heavily biased towards forested ecosystems since these systems are economically important. The animals referenced are usually mammals, but references to reptiles, amphibians, and birds and terrestrial invertebrates can be found in the bibliographies. List of upland plants can be found in Brown (1945), Earles (1975t, Thieret (1972), and USDA (1969). Lists of mammals found in Louisiana and a comprehensive discussion is found in Lowery (1974). Discussions of ecology can be found in Brown (1936) and Linnartz (1968). Flooding effects on forests is discussed in Broadfoot and Williston (1973).

Broadfoot, W. M.; and Williston, H. L., 1973, flooding effects on southern forests: J. Forestry, Vol. 71: 584-587.

Brown, C. A., 1945, Louisiana trees and shrubs: Louisiana Forestry Commission, Bulletin No. 1, Baton Rouge, La.

Brown, C. A., 1936, The vegetation of the Indian mounds, middens and marshes in Plaquemines and St. Bernard Parishes: Dept. of Conservation, La. Geol. Surv., Geological Bulletin No. 8, Baton Rouge, La. 
Earles, J. M., 1975, Forest Statistics for Louisiana Parishes: U.S. Department of Agriculture, Forest Service Resource Bulletin Nos. 50-52.

Linnartz, N. E., ed., 1968, The ecology of southern forests: Proceedings, 17th Annual Forestry Symposium, Louisiana State University, Baton Rouge, La.

Lowery, G. H., Jr., 1974, The mammals of Louisiana and its adjacent waters: Louisiana State University Press, Baton Rouge, La.

Thieret, J. W., 1972, Checklist of the vascular flora of Louisiana, Part I, Ferns and fern allies, gymnosperms, and monocotyledons:

Lafayette Natural History Museum, Technical Bulletin No. 2: 1-48.

U.S. Department of Agriculture, 1969, Forest atlas of the South: U.S. Department of Agriculture, Southern Forest Experiment Station, New Orleans, La. 
C. PLAN FOR THE ACQUISITION OF DATA FOR THE ASSESSMENT
OF POTENTIAL ENVIRONMENTAL IMPACTS ON ECOSYSTEM QUALITY

\section{Introduction}

Since most ecosystem types in Louisiana are poorly understood and since there is so much heterogeneity within any ecosystem, it is proposed that pre-and post-impact studies be broad in scope and synoptic in coverage. Important communities within ecosystem types in a geopressured well field must be inventoried through time to understand the dynamic changes occurring within a yearly cycle. Obviously, this is necessary to understand whether changes, which may be noted postdevelopment, are natural or attributable to the development activities. Furthermore, the study should include non-impacted, similar sites to provide a "control".

Three plans are described below for the assessment of impacts on ecosystem quality: a plan each for offshore geopressured resource development; development in the coastal region; and development in upland and forest regions. This division accomodates the large differences among these regions as to both impacts and environmental setting. The studies proposed are for optimum conditions of funding and planning. These plans were designed for the first fully developed geopressured fields in each of the three regions. A smaller level of effort will be required for subsequent development activities.

The general time-frame for performing ecosystem quality studies is common to the plans for all three regions. The schedule given in Table VII-C-I is keyed to the expected timing of activities as described in 
Table VII-C-1. Schedule for performing ecosystem quality studies.

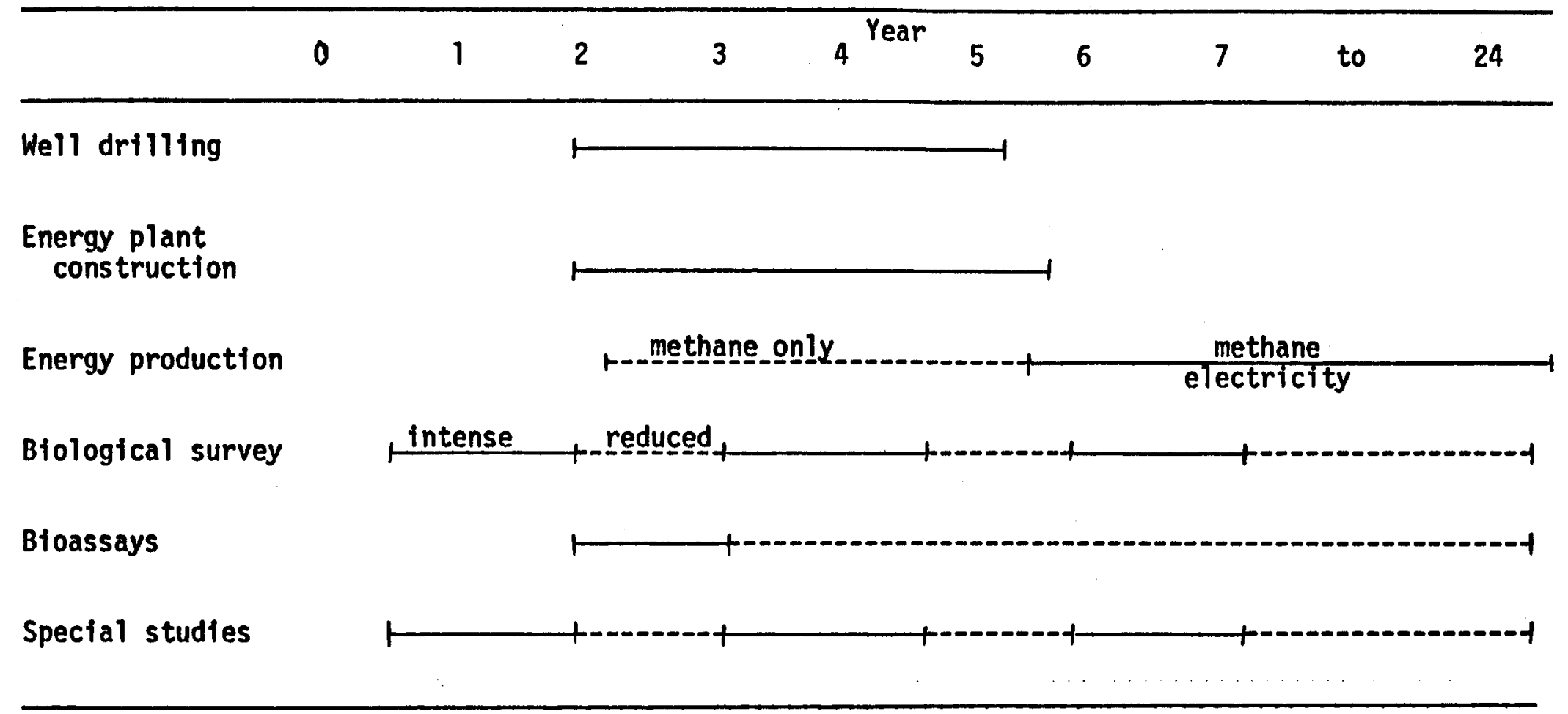

Years $0,1=$ pre-development.

Years $2-24=$ post-development. 
Section III. The rationale behind this schedule is as follows: to reduce the cost of ecosystem quality studies it is proposed that intensive sampling (monthly) be done for only the life of the project. First, an 18 month study will be performed before any development occurs to establish a baseline for that particular site. Second, an 18 month study will be performed during the most intensive portion of well field development and power plant construction. Third, an 18 month study will be performed while gas and electricity are being generated but after all construction has ceased. Between these 3 intensive periods of studies there will be a reduced sampling effort (seasonally or once a year) for the life of the project. In the event of an accidental brine spill or other accidents of significant proportions, intensive sampling, bioassays, and special studies will be resumed al though they may be more limited in scope.

\section{Offshore Development}

Offshore development--i.e. in marine ecosystems--will have the least adverse impacts of the three regions except where onshore facilities and/or corridors are needed.

Important communities in the marine ecosystem are phytoplankton, zooplankton, macrobenthos and fishes. All should be sampled as quantitatively as possible. Water quality and substrate composition should be measured in conjunction with biotic sampling. Since it is possible that geopressured brines will be disposed of in the open Gulf, a series - of bioassays with sensitive species should be accomplished under varying conditions of salinity, temperature, and selected ions concentrations.

Sampling Design. For the field study, two transects will be established perpendicular to the shore. One will cut across the center 
of the proposed drilling field, the second will be parallel but at a distance away from any possible influence of development. Twenty stations will be established and sampled monthly. Three days will be used in sampling offshore each month. The first day phytoplankton, zooplankton and benthos will be sampled at each station. Replicate grabs will be taken from each community. In situ chemistry and samples for nutrients, ions, and chlorophyll will be taken simultaneously. Days 2 and 3 offshore will be used for sampling fishes. Since pipelines and transmission lines will cross land areas, a fourth day should be used to sample several stations in the marsh ecosystems affected. If offshore drilling rigs are being used in the study area, fishes can be counted visually by divers.

Acute and chronic bioassays will be conducted with indigenous vertebrates and invertebrates. Organisms, including both adult and early life history stages, will be subjected to ranges of salinity, temperature and selected ions characteristic of the local geothermal brines. Table VII-C-2 gives the costs for performing ecosystem quality studies for a single offshore geopressured well field.

\section{Coastal Development}

The value of unaltered marsh has been estimated by Gosselink, et. a1., (1973) as $\$ 2,000 /$ acre/year on the basis of its productivity; the recreational and cormercial value of the biota, and other factors. Of the three regions, the coastal region is the most vulnerable to impacts from geopressured resource development, and should be studied extensively:

Important communities in the estuarine and marsh ecosystems include fishes, meiobenthos, macrobenthos, zooplankton, regetation, and ter- 
Table VII-C-2. Estimated costs: Ecosystem quality studies at an offshore geopressured site.

\begin{tabular}{|c|c|c|c|c|c|c|c|c|}
\hline & 0 & 1 & 2 & $\begin{array}{c}\text { Year } \\
3 \\
\end{array}$ & 4 & 5 & 6 & 7 \\
\hline ITEM & \multicolumn{8}{|c|}{ (thousands of dollars) } \\
\hline \multicolumn{9}{|c|}{ Salaries \& Wages } \\
\hline $\begin{array}{l}\text { Principal } \\
\text { Associates } \\
\text { Assistants }\end{array}$ & $\begin{array}{l}18.0 \\
26.0 \\
34.0\end{array}$ & $\begin{array}{l}18.9 \\
26.0 \\
36.0\end{array}$ & $\begin{array}{l}19.8 \\
26.0 \\
22.0\end{array}$ & $\begin{array}{l}20.7 \\
54.0 \\
42.0\end{array}$ & $\begin{array}{l}21.6 \\
26.0 \\
36.0\end{array}$ & $\begin{array}{l}22.5 \\
26.0 \\
18.0\end{array}$ & $\begin{array}{l}23.4 \\
26.0 \\
38.0\end{array}$ & $\begin{array}{l}24.3 \\
26.0 \\
34.0\end{array}$ \\
\hline $\begin{array}{l}\text { Benefits \& } \\
\text { Overhead }\end{array}$ & 44.7 & 46.4 & 38.9 & 66.9 & 47.9 & 38.1 & 50.1 & 48.3 \\
\hline Trave 1 & 19.0 & 20.0 & 10.0 & 20.0 & 18.0 & 10.0 & 20.0 & 17.0 \\
\hline $\begin{array}{r}\text { Supplies \& } \\
\text { Expenses }\end{array}$ & 16.0 & 17.0 & 12.0 & 17.0 & 16.0 & 12.0 & 17.0 & 15.0 \\
\hline Equipment $^{\mathrm{a}}$ & 118.0 & 5.0 & 3.0 & -- & -- & -- & -- & -- \\
\hline TOTAL & 275.7 & 169.3 & 131.7 & 220.6 & 165.5 & 126.6 & 174.5 & 164.6 \\
\hline
\end{tabular}

ancludes all field and laboratory equipment costs needed to perform the proposed studies.

Years $0,1=$ pre-development

Years $2-7=$ post development 
restrial vertebrates. Surveys of these fauna for two years in both a developed area and a control area are needed to distinguish normal variation from that related to geopressured resource development. Bioassays with selected species should also be performed with both brine and air pollutants.

Sampling Design. Siting stations will be complicated by the heterogeneity of habitats within the systems. However, stratified random sampling should be a valid approach. Logistical problems are reduced compared to marine studies, consequently equipment outlay should be less. Again, all stations should be sampled at least monthly for an 18 month pre-impact period study; an 18 month period during the construction phase; and an 18 month period during operation. Reduced sampling will take place between these periods and for the life of the development project--20 years from the completion of the energy plant. Sampling will require a field team of five to seven people for a period of 4 days each month. Fishes should be sampled in canals and isolated ponds by seining, beam trawling and with plankton nets. Macrobenthos in open water should be sampled with ponar grabs and in marshes by a box corer. Meiobenthos should be taken monthly in at least three sites. A marsh, and an open, intertidal water body transect will be located within and outside the impacted area. Changes in water quality and substrate composition will be monitored along with biota collections. Vegetation within the area of intensive activity will be mapped using transect methods. Birds, marmals, and reptiles will be directly censused at least four times a year.

Bioassays using selected organisms will be conducted in a manner as described under marine studies. Table VII-C-3 gives the costs for 
Table VII-C-3. Estimated costs: Ecosystem quality studies at a coastal geopressured site.

\begin{tabular}{|c|c|c|c|c|c|c|c|c|}
\hline & 0 & 1 & 2 & $\begin{array}{c}\text { Year } \\
3\end{array}$ & 4 & 5 & 6 & 7 \\
\hline ITEM & \multicolumn{8}{|c|}{ (thousands of dollars) } \\
\hline \multicolumn{9}{|c|}{ Salaries \& Wages } \\
\hline $\begin{array}{l}\text { Principal } \\
\text { Associates } \\
\text { Assistants }\end{array}$ & $\begin{array}{l}18.0 \\
26.0 \\
34.0\end{array}$ & $\begin{array}{l}18.9 \\
26.0 \\
35.0\end{array}$ & $\begin{array}{l}19.8 \\
26.0 \\
22.0\end{array}$ & $\begin{array}{l}20.7 \\
54.0 \\
41.0\end{array}$ & $\begin{array}{l}21.6 \\
26.0 \\
36.0\end{array}$ & $\begin{array}{l}22.5 \\
26.0 \\
18.0\end{array}$ & $\begin{array}{l}23.4 \\
26.0 \\
37.0\end{array}$ & $\begin{array}{l}24.3 \\
26.0 \\
34.0\end{array}$ \\
\hline $\begin{array}{r}\text { Benefits \& } \\
\text { Overhead }\end{array}$ & 44.7 & 45.8 & 38.9 & 66.3 & 47.9 & 38.1 & 49.5 & 48.3 \\
\hline Travel & 16.0 & 16.0 & 10.0 & 20.0 & 16.0 & 8.0 & 16.0 & 16.0 \\
\hline $\begin{array}{r}\text { Supplies } \& \\
\text { Expenses }\end{array}$ & 16.0 & 16.0 & 10.0 & 20.0 & 16.0 & 8.0 & 16.0 & 16.0 \\
\hline Equipment ${ }^{a}$ & 83.2 & 5.0 & 2.0 & -- & $\cdots$ & --- & -- & $\because-$ \\
\hline TOTAL & 237.9 & 162.7 & 128.7 & 222.0 & 163.5 & 120.6 & 167.9 & 164.6 \\
\hline
\end{tabular}

ancludes all field and laboratory equipment needed to perform the proposed studies.

Years $0,1=$ pre-development

Years $2-7=$ post-development 
acquiring these data for a single geopressured well field in the coastal region.

\section{Upland and Forest Development}

Productivity in upland and forest regions is lower than in the coastal ecosystems. Therefore, potential impacts will not be as severe, in genera 1.

Upland areas and bottomland hardwood forests can be studied using the same general methods. Communities of interest include vegetation, terrestrial vertebrates, macrobenthos, phytoplankton and fish. Variation in water chemistry and soil chemistry should be monitored in this study. Biological assays with selected species of terrestrial and aquatic biota should also be performed.

Sampling Design. Stratified random sampling of aquatic ecosystems and transect mapping of terrestrial ecosystems will give baseline and post-impact information. Frequency of sampling aquatic resources should be at least monthly, while terrestrial communities should be studied seasonally. Fishes of ponds, lakes, and streams should be sampled using seines and electrofishing. Macrobenthos should be sampled with Ekman grabs, but in coarse sediments a Ponar dredge should be used. Phytoplankton in lakes and ponds will be sampled and djel estimates (On a seasonal basis) of primary production will be made by the dissolved oxygen and chlorophyll method. Vegetation will be mapped and terrestrial vertebrates will be directly censused.

Some bioassay studies with freshwater organisms with potentially toxic ions from the brine should be undertaken. Since cooling tower blowdown may be a problem, ions in that effluent should be tested. Table VII-C-4 gives the costs of acquiring this data for a single geopressured well field in upland and/or forest regions. 
Table VII-C-4. Estimated costs: Ecosystem quality studies at an upland site.

\begin{tabular}{|c|c|c|c|c|c|c|c|c|}
\hline ITEM & 0 & 1 & 2 & $\begin{array}{c}\text { Year } \\
3 \\
\end{array}$ & $\frac{4}{201}$ & 5 & 6 & 7 \\
\hline ITEM & \multicolumn{8}{|c|}{ (thousands of dollars) } \\
\hline \multicolumn{9}{|c|}{ Salaries \& Wages } \\
\hline $\begin{array}{l}\text { Principal } \\
\text { Associates } \\
\text { Assistants }\end{array}$ & $\begin{array}{l}18.0 \\
26.0 \\
34.0\end{array}$ & $\begin{array}{l}18.9 \\
26.0 \\
35.0\end{array}$ & $\begin{array}{l}19.8 \\
26.0 \\
22.0\end{array}$ & $\begin{array}{l}20.7 \\
54.0 \\
41.0\end{array}$ & $\begin{array}{l}21.6 \\
26.0 \\
36.0\end{array}$ & $\begin{array}{l}22.5 \\
26.0 \\
18.0\end{array}$ & $\begin{array}{l}23.4 \\
26.0 \\
37.0\end{array}$ & $\begin{array}{l}24.3 \\
26.0 \\
34.0\end{array}$ \\
\hline $\begin{array}{l}\text { Benefits \& } \\
\text { Overhead }\end{array}$ & 44.7 & 45.8 & 38.8 & 66.3 & 47.9 & 38.1 & 49.5 & 48.3 \\
\hline Travel & 12.0 & 13.0 & 8.0 & 15.0 & 14.0 & 12.0 & 15.0 & 14.0 \\
\hline $\begin{array}{l}\text { Supplies \& } \\
\text { Expenses }\end{array}$ & 15.0 & 16.0 & 10.0 & 18.0 & 16.0 & 15.0 & 18.0 & 16.0 \\
\hline Equipment ${ }^{a}$ & 80.0 & 10.0 & 4.0 & $\cdots$ & --- & -- & +- & $\cdots$ \\
\hline TOTAL & 229.7 & 164.7 & 128.6 & 215.0 & 161.5 & 131.6 & 168.9 & 162.6 \\
\hline
\end{tabular}

ancludes all and laboratory equipment needed to perform the proposed studies.

Years $0,1=$ pre-development

Years $2-7=$ post development 
(

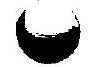




\section{SOCIOECONOMIC AND CULTURAL CONSIDERATIONS}

A. Introduction

B. Land Use

C. Resources

D. Natural Hazards 
$=\frac{1}{1}$

.

$\pm$

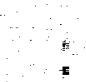

-

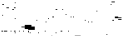


A. INTRODUCTION

R. A. Muller, A. L. Bachman, and R. Hilding

The economic and cultural resources of the area of interest for geopressured resource development in Louisiana are rich and varied. The study area includes major population centers as well as large tracts of wetlands where few people maintain permanent residences. The purpose of this Section is to describe the study area with respect to these resources and population patterns, and to identify problem areas of concern in the full-scale development of geopressured resources.

The subject of impacts from ancillary development activities: i.e., residential, commercial, and industrial activities as a result of secondary uses of the spent geopressured brines has not been addressed here or elsewhere in this Report. This subject was determined to be beyond the scope of the research, given time and funding constraints. It is an area of significant concern and interest, however. Secondary users of geopressured hot water would have to be located close to the well field in order to minimize heat losses from the power plant to the point of end use. Many of the geopressured prospects, and the majority of the prime prospects, are located in rural areas and in fragile wetland ecosystems. Industrial activity in these areas, along with the residential and commercial activities that could follow, would have a significant impact on the natural environment and on human uses of that environment. These impacts would be much larger relative to impacts associated with methane and electricity production from geopressured fluids, particularly in terms of socioeconomic and cultural resources. For this reason, a plan for the assessment of 
impacts in this area has not been formulated. Such a plan should await input from research on impacts from ancillary development activities.

In general, impacts on socioeconomic and cultural resources from the primary activities of geopressured resource development: site preparation and construction, fiuid production and disposal, methane and electricity production and transportation, are similar to impacts from oil and conventional gas production. $0 i 1$ and gas production in the study area is intensive and has been for several decades. The impacts in terms of income, demand for community services, growth, and the like have been of major significance during this period. Similar impacts from geopressured development will result and add to those already on-going.

There are, however, two types of impacts from geopressured development that differ markedly from those of oil and gas production. Subsidence, should it occur as a result of geopressured fluid production, could have important impacts on land use, structures, flooding potential, and the like, and is of major concern. The area subject to flooding from storm surges and stream discharge could be significantly increased should subsidence occur in the low lying, low relief portions of the study area. Differential subsidence could result in damage to structures and roads.

Possible impacts resulting from subsurface fluid disposal: i.e., breeching of abandoned wells, leakage into fresh-water aquifers, are unique to geopressured operations in that the volume of spent fluid is so much greater than oil and gas field brines. Brine spills and ground-water contamination could impact on land and water uses in the study area. Of particular concern are the ground-water resources 
used for irrigating rice crops in the south-central and southwest portions of the study area.

Natural hazards such as hurricanes and accompanying storm surges, high winds and tornadoes, and fresh-water flooding are also discussed in this section. The oil and gas industry. in south Louisiana has developed procedures and safeguards for these occurrences. Nevertheless, weather events and flooding still pose hazards to life and equipment. More important to this research is the degree of flooding from storm surges and fresh-water runoff that occurs in the study area. Flood prone areas could be appreciably increased in extent should subsidence occur as a result of geopressured operations. The socioeconomic and cultural setting of the study area is described below. Other sections of the Report bear on this discussion; particularly the sections on geological effects (Section IV), air and water quality (Sections V and VI), and ecosystem quality (Section VII). 


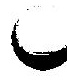




\section{B. LAND USE}

1. Introduction

Historically, land use in south Louisiana has been mostly determined by the opportunities and constraints of the natural environment. Settlement and development occurred mainly on the Pleistocene terraces, natural levees, ridges, and cheniers; while the undeveloped wetlands were utflized for such activities as fishing and trapping. Within this century human activity has greatly altered the natural situation. The Mississippi and Atchafalya Rivers have been controlled for purposes of navigation and flood protection by channelization and the construction of artificial levees. An extensive network of canals has been cut through the wetlands to provide access for 011 and gas production, for navigation, and other purposes. Large projects for land reclamation have been undertaken. These changes have taken their toll on the natural environment. Flood control has eliminated the overbank flooding which distributed river sediments into swamp and marsh areas; and the many canals have al tered the natural discharge and exchange of waters within the wetlands, as well as contributed to land loss in the wetlands.

Recently, a crisis over land use has been recognized in Louistana. Since the wetlands represent a valuable renewable resource, a conscientious effort has been made to preserve and protect this system. On the other hand, the need for increased development of oil and gas resources and the increased demand for urban and agricultural land presents a threat to the wetlands. In order to reconcile these uses of the wetlands, a plan for comprehensive management of resources in the coastal region is being developed. A data base on land use and resources has been assembled in support of these efforts. This work has been carried out 
under the U. S. Coastal Zone Management Act of 1972 and legislation is pending in Louisiana to implement a coastal zone management program.

\section{Population}

Approximately 2.5 million people live in the area of interest for geopressured resource development. The population distribution in the study area is quite varied (Figure VIII-B-1). Over one million people are concentrated in the New Orleans metropolitan area to the east; while to the west, Cameron Parish has no communities over 500 inhabitants. Major population centers in the study area are New Orleans, Baton Rouge, Lafayette and Lake Charles. The coastal wetlands and the wetlands of the Atchafalaya Basin are relatively sparsely populated. Most of the geopressured prospect areas are in rural portions of the study area.

The majority of the parishes in the study area are experiencing population growth (Figure VIII-B-2). Much of this growth has been in the areas projected as urban growth corridors (Figure VIII-B-3), although rural population gains are also evident.

A large percentage of the labor force in the study area is employed in mining--particularly the oil and gas industries. Figure VIII-B-4 shows this to be true especially in the coastal parishes--the area of prime interest for geopressured development. Since the type of jobs associated with geopressured operations are expected to be similar to those associated with oil and gas, these workers represent an available, skilled labor force for geopressured development.

3. Industrial Activity

Industrial activity in Louisiana is concentrated primarily in two 
Fig.VIH-B-2 Louisiana parishes by rate of growth, 1970-1976. (From U.S. Department of Commerce, 1977a).

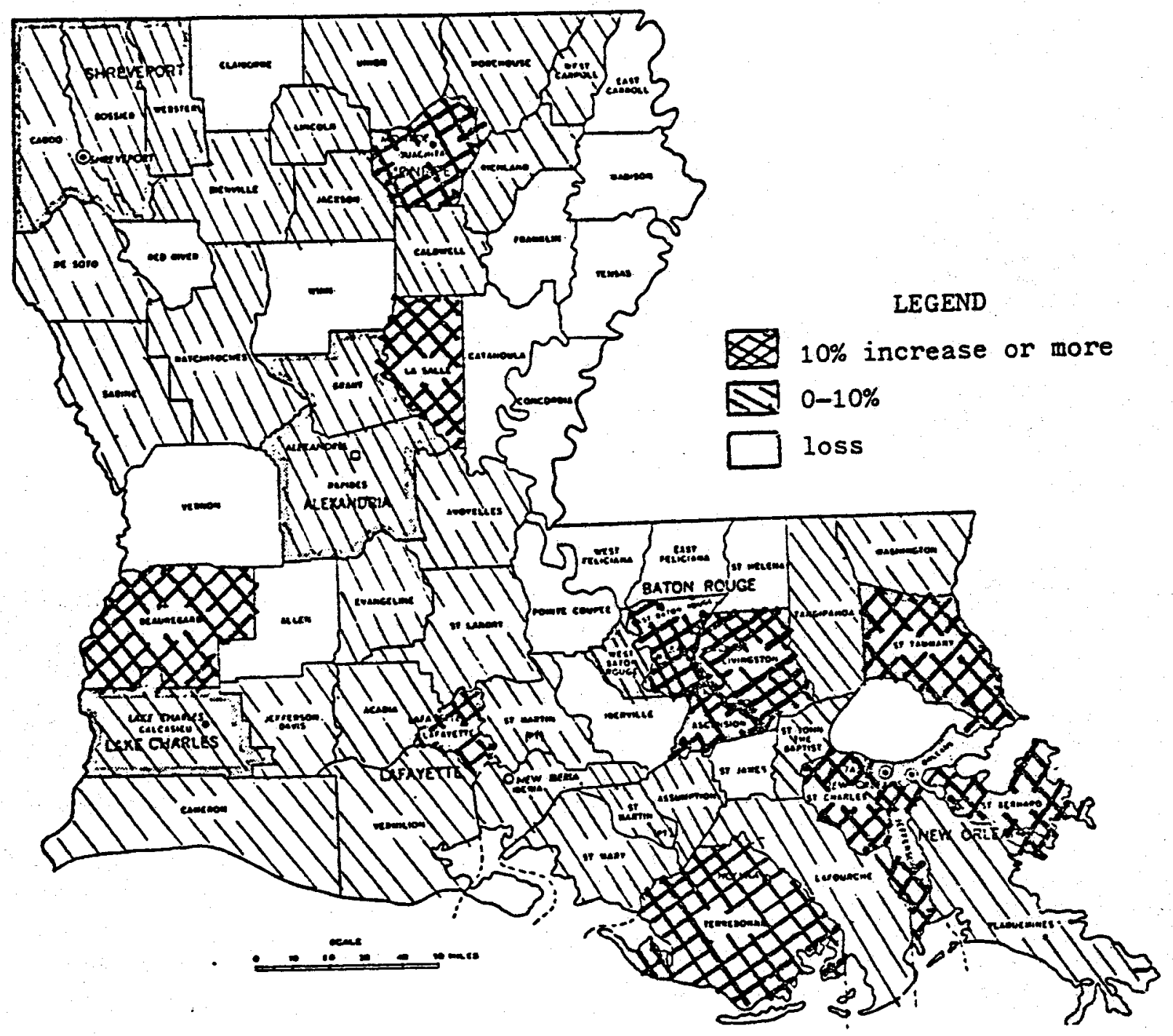


Fig. VIII-B-3. Projected urban growth corridors. (From U.S. Army Corps of Engineers, 1976).

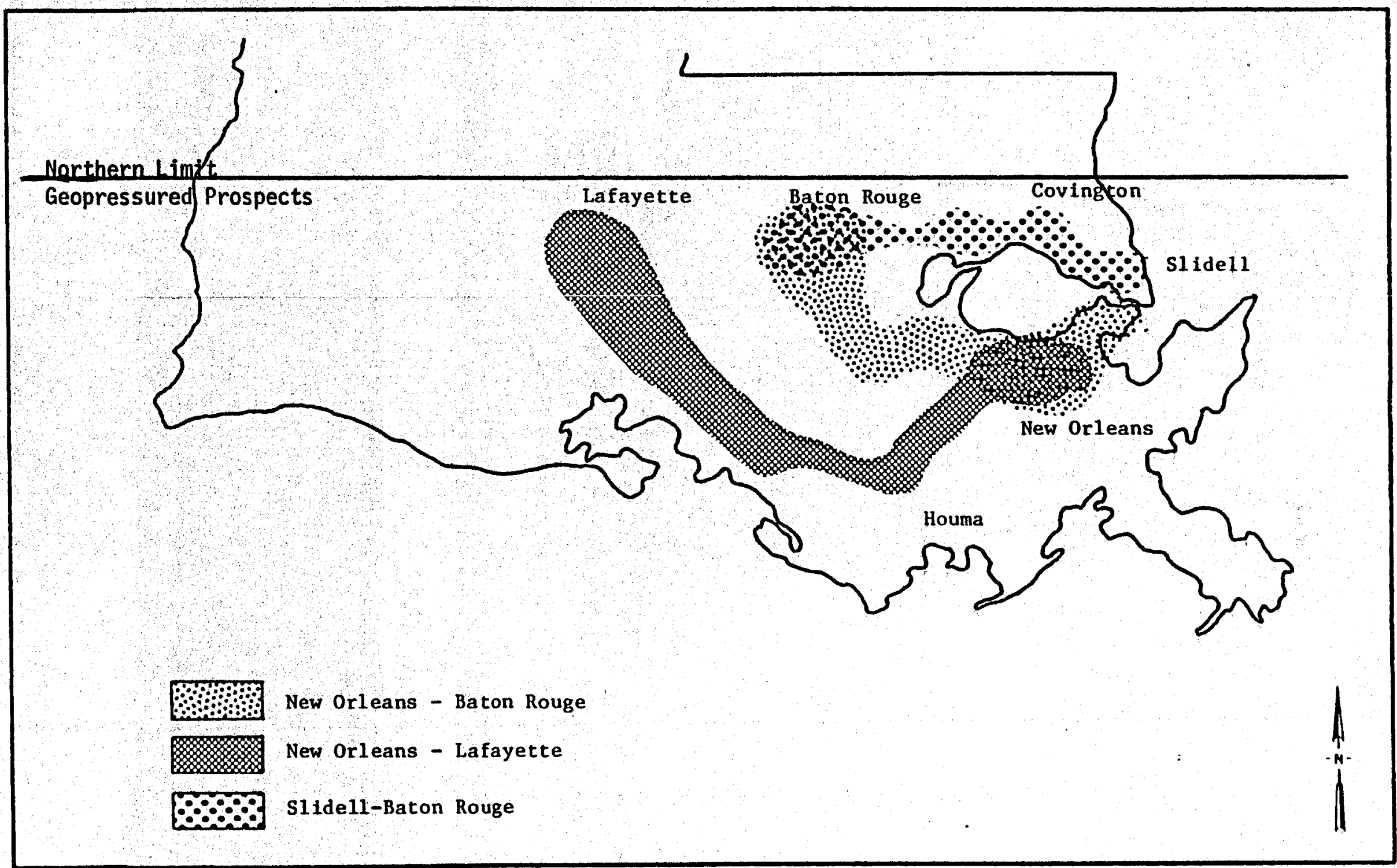


Fig. VIII-B-4. Mining as a percent of total parish employment. (From U.S. Army Corps of Engineers, 1976).

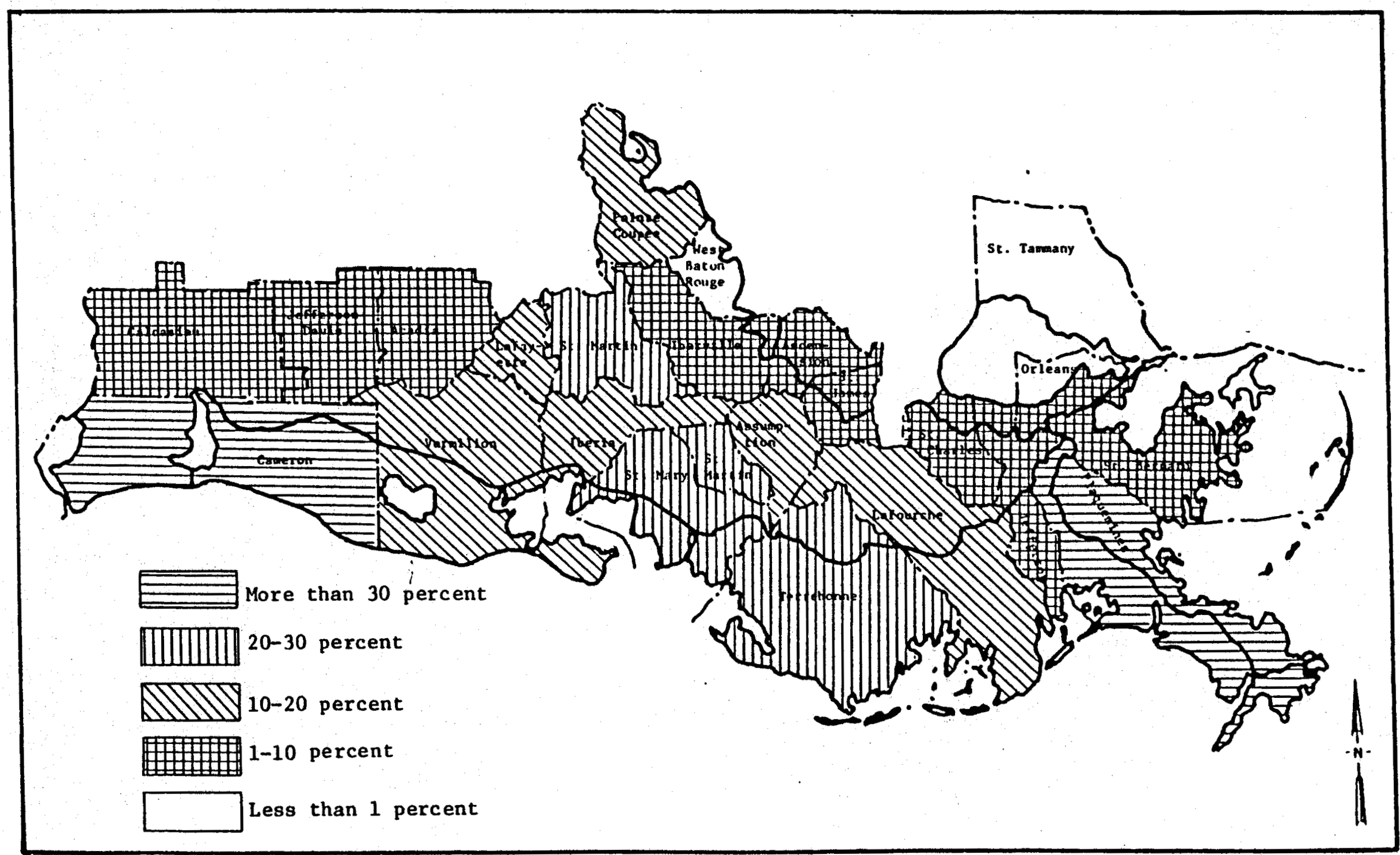


areas: a strip along the Mississippi River between the major urban centers of Baton Rouge and New Orleans, and in the Lake Charles area in Calcasieu parish. $0 i 1$ refineries and petrochemical plants are the major industrial activities in both these areas, and further development is being encouraged. Figure VIII-B-5 shows these concentrations. Other types of manufacturing, construction, and mining are also of major importance in the study area. (Mining is discussed in Section VIII-B, below).

Several geopressured prospect areas are located within or near these industrial concentrations. The contribution of geopressured operations to air and water pollutant loadings, both of which are already high in these areas, is of some concern.

\section{Agriculture}

Agriculture is an important land use in south Louisiana. It is a major economic activity in 10 of the 30 parishes in the study area, as Figure VIII-B.6 illustrates. In 9 of these parishes: Acadia, Ascension, Assumption, Calcasieu, Iberville, Jefferson Davis, Pointe Coupee, St. Martin, and St. Tammany; $50 \%$ of the land is in agriculture (U. S. Army Corps of Engineers, 1976).

Figure VIII-B-7 shows major agricultural regions in the study area. In the wetland areas, both near the coast and in the Atchafalaya Basin, beef is the main crop, excluding fish harvests. Cattle are grazed on the cheniers and ridges of the coastal marshes, and on higher ground in the inland wetlands. Sugar cane is still an important crop. in the central and eastern portions of the study area, al though much sugar cane acreage is being converted to soy beans because of recent declines in the price of sugar. Beef and dairy production east of the Mississippi River is 
Fig. VIII-B-5. Payrolls in petroleum and chemicals. (From Newton, 1972).
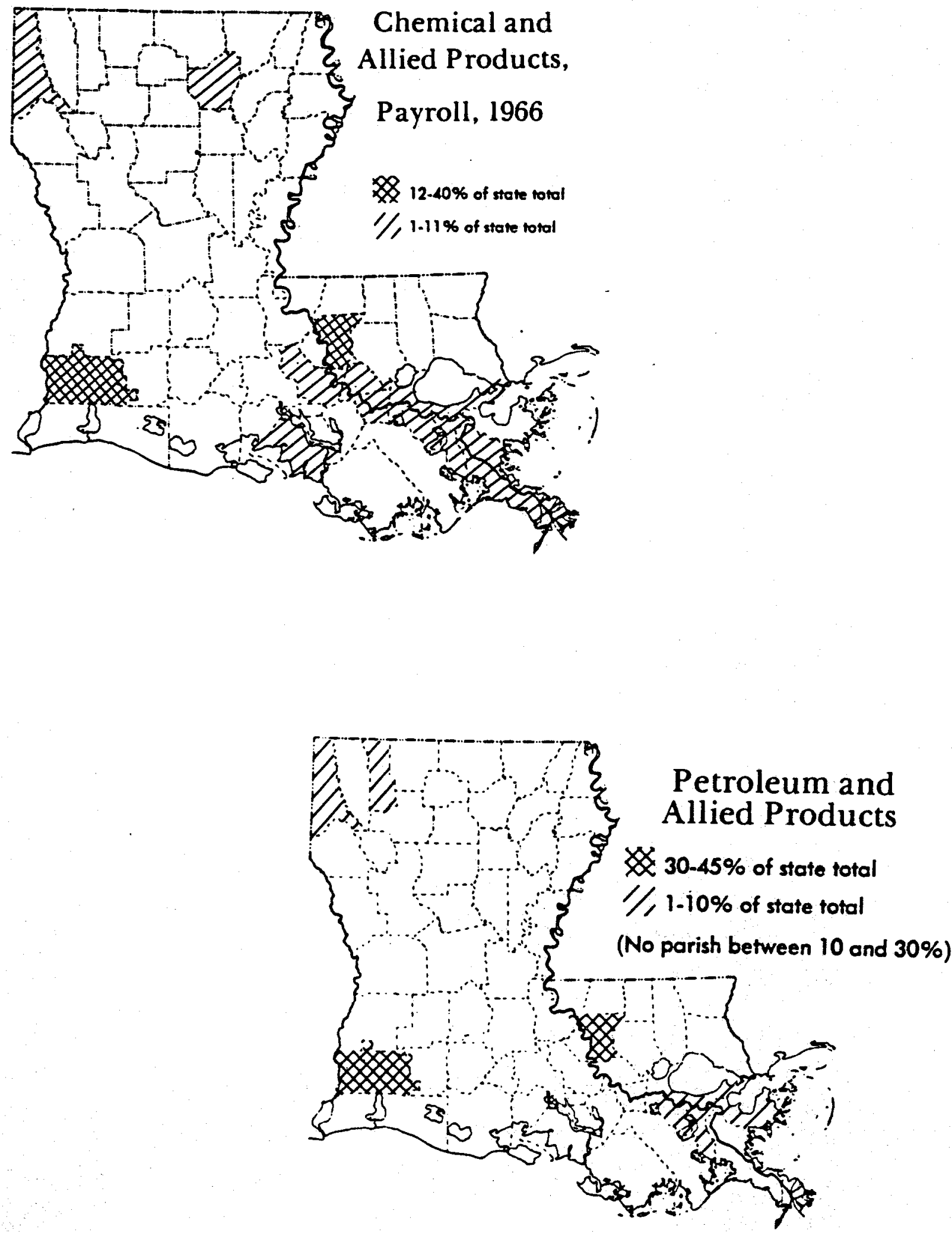
Fig. VIII-B-6. Parish farm income. (From Louisiana State Planning Office, 1977).

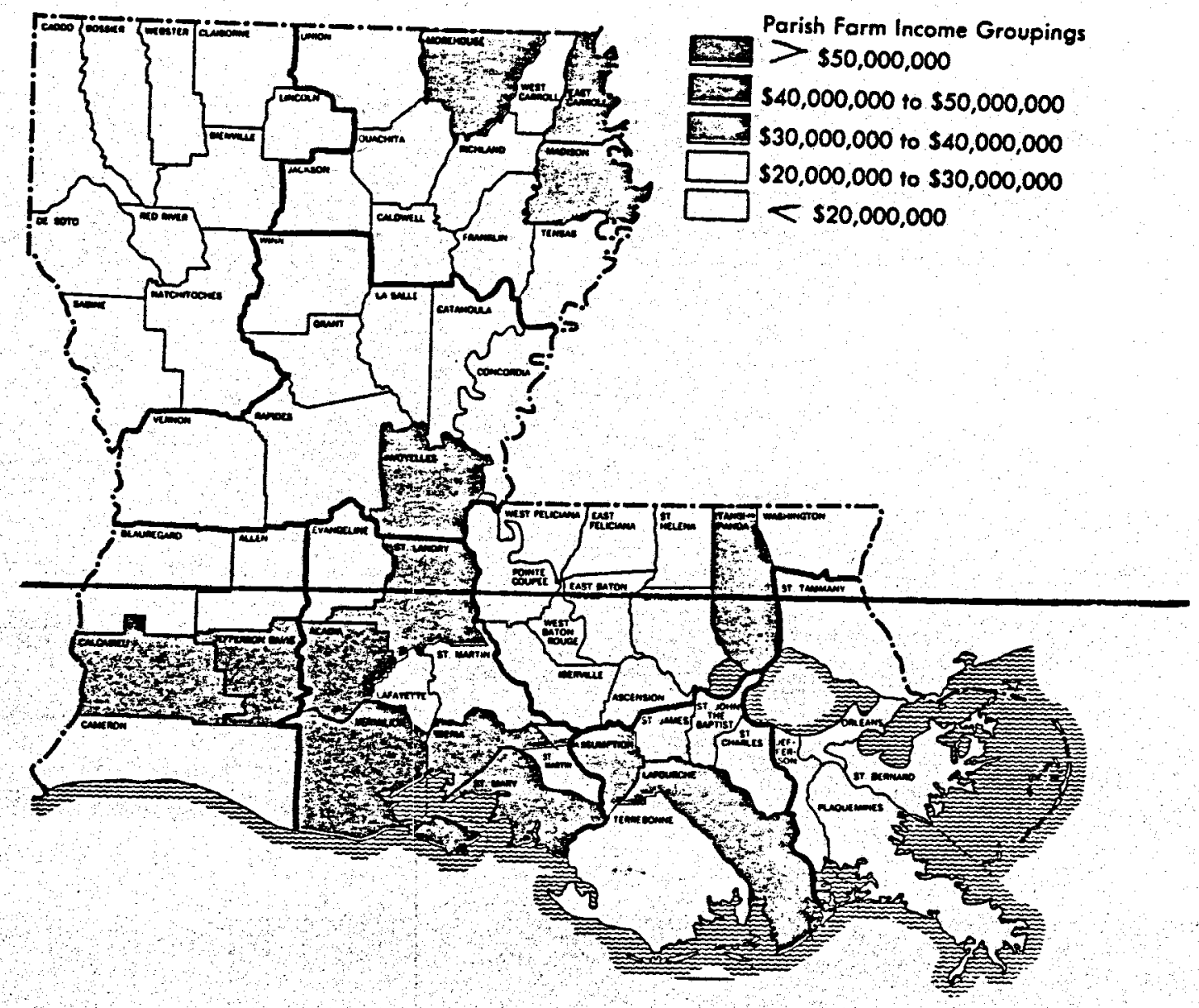




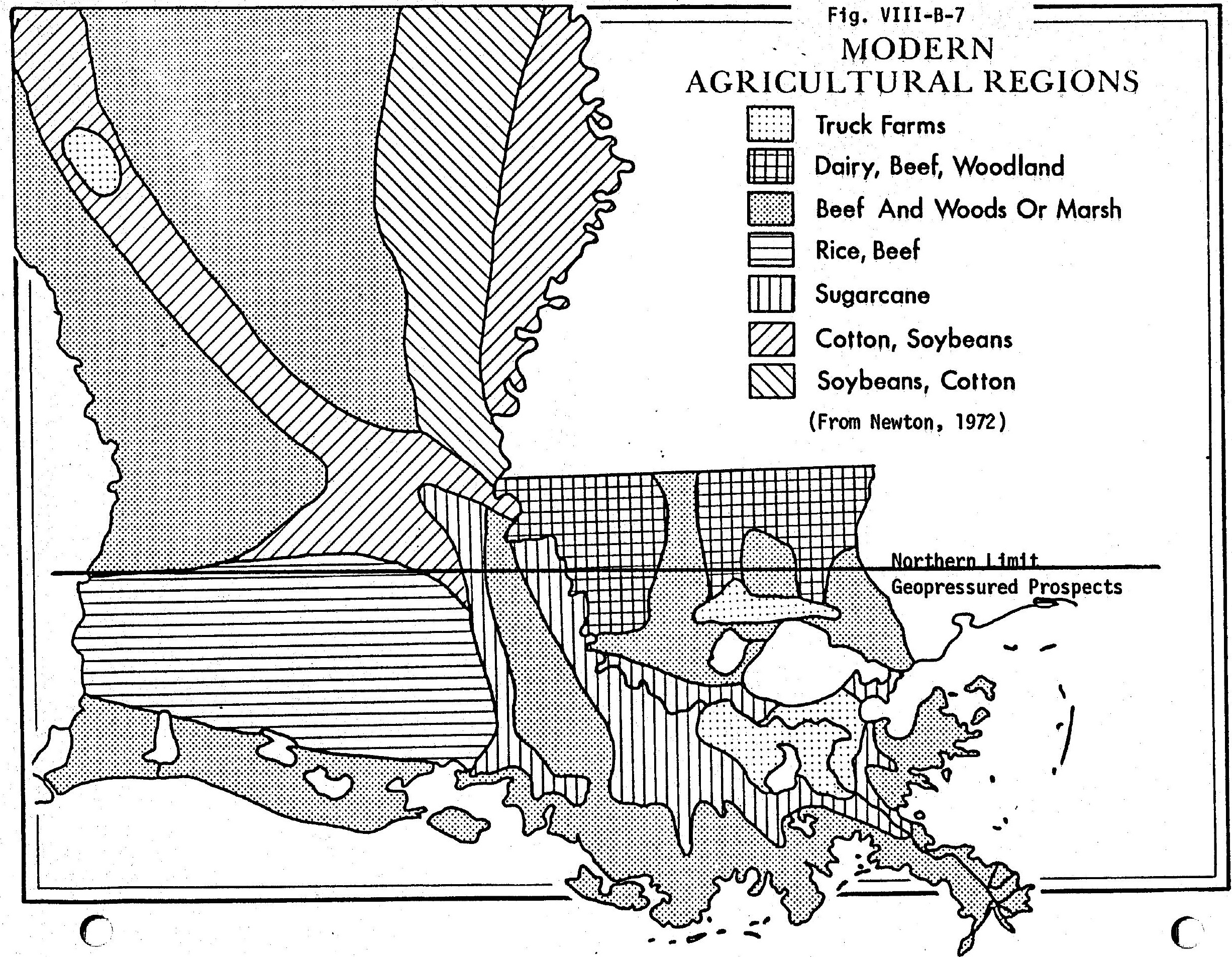

ڤ్̊ 
also declining in favor of soy beans.

Rice remains the major crop in the western portion of the study area. Rice is the only irrigated crop in Louisiana; irrigation water coming mainly from fresh ground water. This source is already being eroded due to salt water encroachment from the Gulf. Any further contamination from accidental leakage during disposal of geopressured brines, for example, . will be of considerable concern.

\section{Recreation}

Considerable 1 and and water acreage is set aside in south Louisiana for recreation, reflecting the abundance of wildlife in the area. The largest acreage is in state wildlife management areas and state and federal wildlife refuges (Figures VIII-B-8 and -9 ). Hunting and fishing are the primary recreational activities in the wildlife management areas.

0 il and gas operations are allowed on state owned refuges and wildlife management areas. In fact, the primary source of income from these areas is revenue from 011 and gas production (Herring, personal communication, 1977). The Louisiana Department of Wildlife and Fisheries regulates, to an extent, construction and production practices to protect the wildlife and recreational value of the areas. While a number of prime geopressured prospects are located in or near state and federal wildlife areas and refuges, it is highly unlikely that full-scale geopressured development activities would be allowed to take place in these areas.

Sport hunting and fishing is popular throughout south Louisiana. The value of these activities is high with sport licenses alone generating over $\$ 1$ million a year in income (La. Wildlife and Fisheries Commission, 1972). Of particular concern in the coastal marsh areas in terms of adverse effects on recreational hunting and fishing from geopressured operations, is the potential impacts of subsidence, should 
Fig. VIII-B-8. Louisiana state recreation land, south Louisiana. (From U.S. Army Corps of Engineers, 1976).

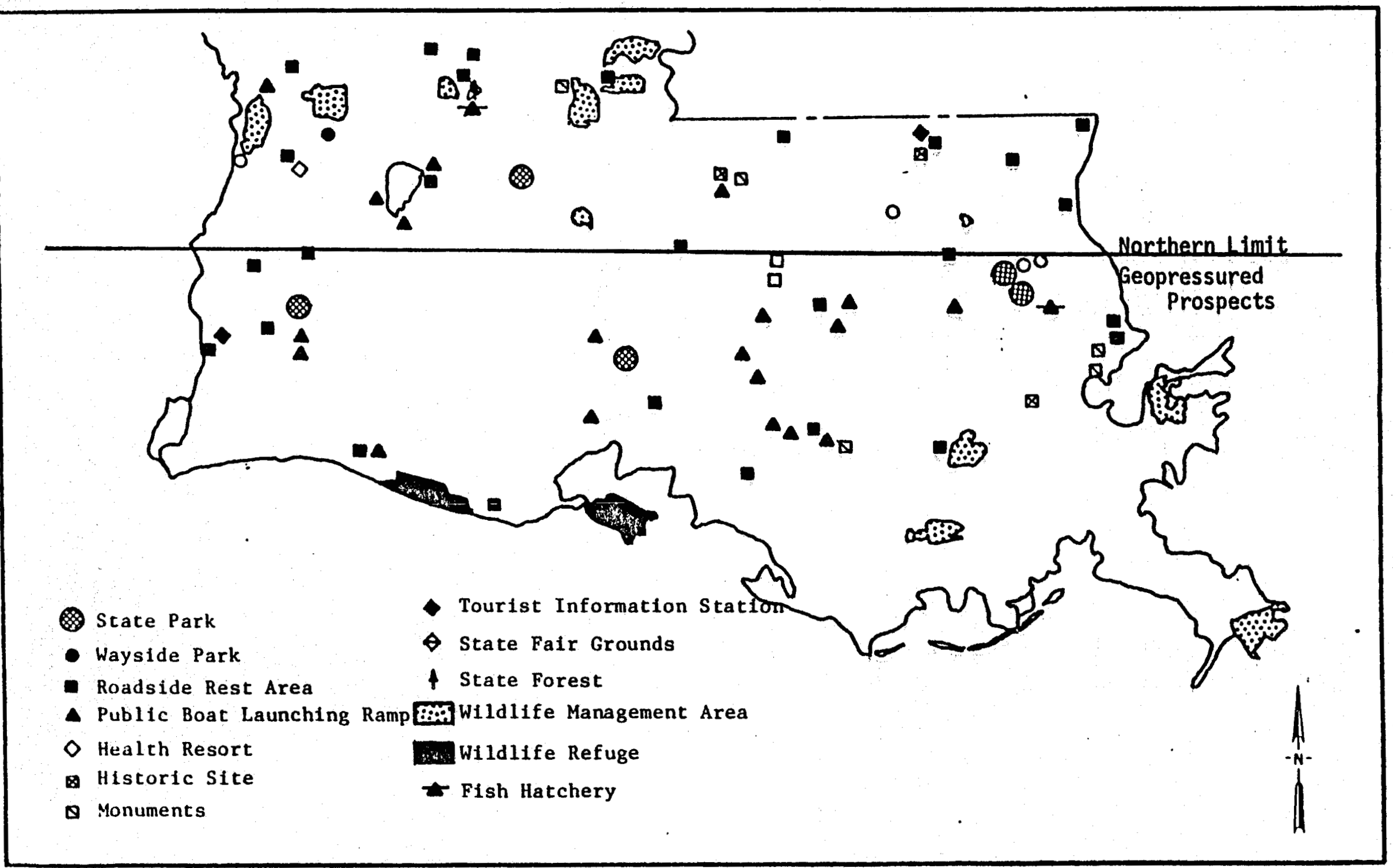

$\tilde{O}$ 
Fig. VIII-B-9. U.S. Government recreation land, south Louisiana. (From U.S. Army Corps of Engineers, 1976).

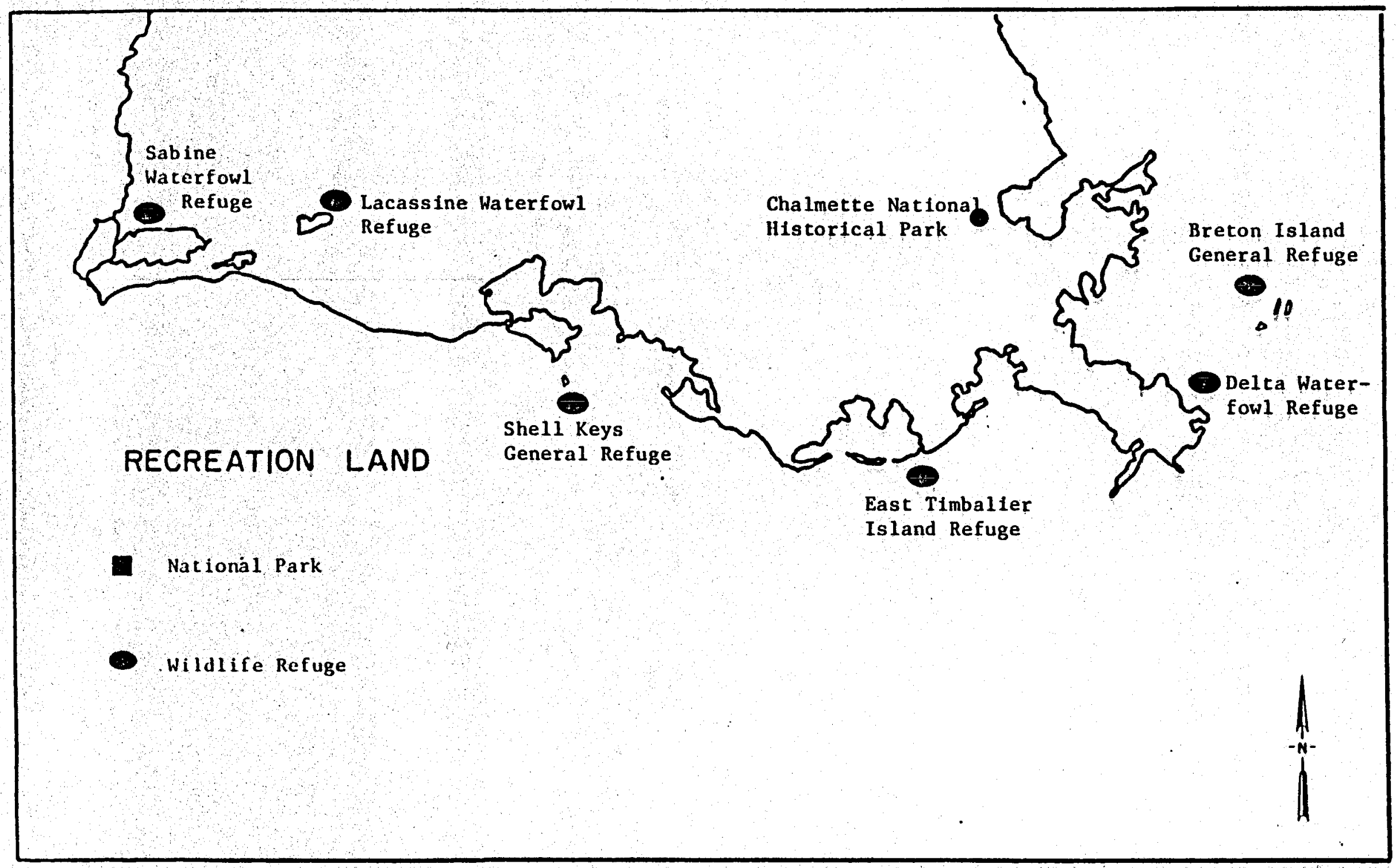


it occur, and of accidental brine spills. The large extent of pipeline required to transport geopressured fluid to the energy plant and back to disposal wells is also of some concern in that surface disruption is likely to be quite high in wetland areas. 


\section{RESOURCES}

\section{Renewable Resources}

Chief among the renewable resources of south Louisiana are fish and shellfish. The distribution of the ma in commercial species are shown in Figure VIII-C-1, with the values of 1975 commercial landings listed in Table VIII-C-1. The recreational value of these species was described in Section $B$, above.

Game is also an important resource, both commercially and recreationally. The total value of the commercial fur take in Louisiana in 1976 was $\$ 13.8$ million with nutria and muskrat accounting for $\$ 10.5$ million of this amount (La. Office of State Planning, 1977). The coastal marshes are the primary habitat for nutria and muskrat. Water fowl are also important commercial and sport animals in the coastal marshes.

The section on ecosystem quality (Section VII) describes in detai] the impacts on wildlife that could occur due to geopressured resource development. The issue in terms of economic, social and cultural values is somewhat broader than just the possible loss of wildlife and/or habitat for wildlife, however. The coastal wetlands of Louisiana are themselves a valuable renewable resource. Marsh systems flush wastes from agricultural, municipal and industrial sources; and act as a buffer against storm surges. The wetlands are also of prime ecological interest. They provide habitat for a number of threatened and endangered species. While considerable mineral extraction-particularly oil and gas production--takes place in and adjacent to south Louisiana wetlands, these activities, including geopressured development, need to be carried out in a manner consistent with the protection of the coastal wetlands:

of paramount concern is land loss in the wetlands. Subsidence, 

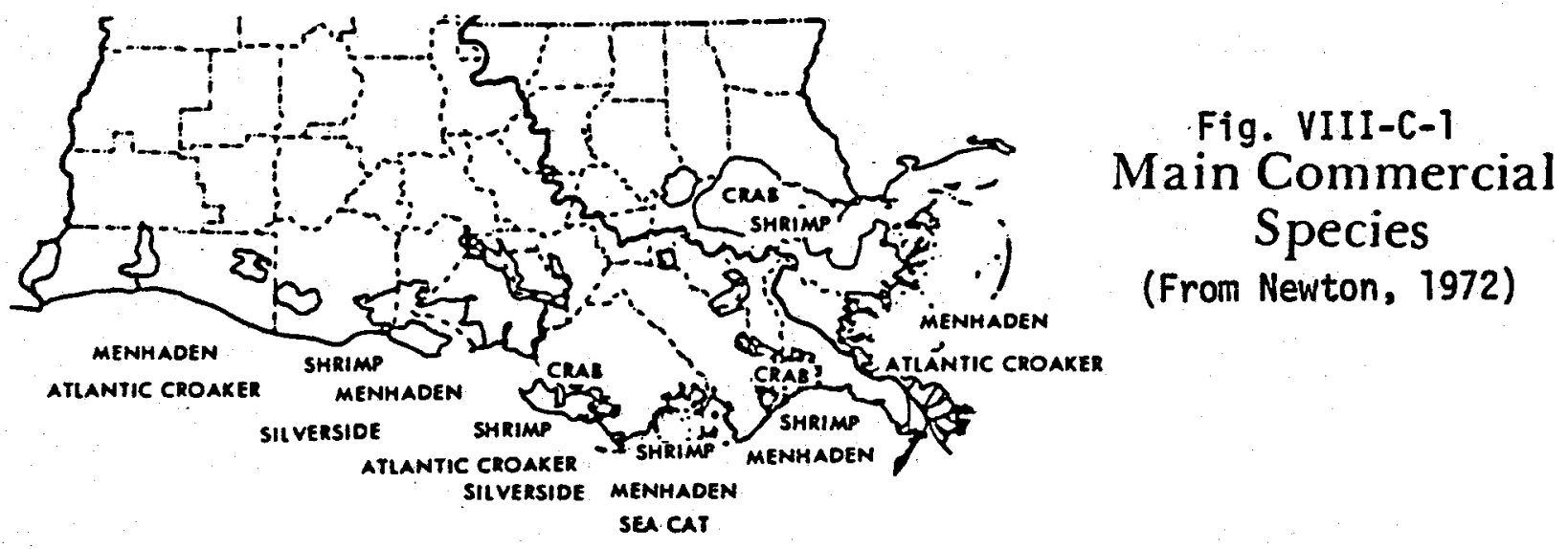

FISHERIES

TABLE VIII-C-1. Value of Louisiana commercial landings, fish and shellfish, 1975. (From La. State Planning Office, 1977).

Species

Menhaden

Catfish \& Bullheads

Sea Trout, Spotted

Buffal ofish

Drum

Shad

Other

TOTAL FISH

Shrimp

Oysters

Crawfish

Crabs

Other

TOTAL SHELLFISH

GRAND TOTAL
Dollar Value

$$
\begin{array}{r}
29,379,319 \\
2,615,550 \\
695,978 \\
395,868 \\
329,624 \\
72,991 \\
1,300,030 \\
34,789,360
\end{array}
$$

$40,967,755$

$7,174,309$

$3,330,942$

$2,570,033$

213,304

$54,196,343$

$88,985,703$ 
if it should occur during geopressured operations, could result in considerable land loss in the flat, low-lying coastal region. Because the value of marsh areas is higher than open water systems, the potential exists for decreasing the value of land due to inundation from subsidence. Harre11, in his research on legal aspects of geopressured resource development (1978), believes that this situation could result in legal action by individuals or the State seeking injunctive relief from the effects of the geopressured operation. Subsidence effects would be likely to be construed as resulting from the normal operations of the development, so injunctive relief would mean closing down the operation.

This hypothesis is speculative, at best; dependent on a number of factors that are highly uncertain. We don't know if subsidence will occur or, if it does, how much will occur. Subsidence must be shown to be attributable to the geopressured operation in a geographic area in which natural and induced subsidence is already taking place; and individuals or the state must bring suits and these must be decided in the courts. In spite of these uncertainties, the whole area of subsidence prediction, prevention and monitoring requires close attention. The State's concern is fllustrated in the proposed regulations for geopressured operations which require subsidence monitoring (Harrel1, 1978).

\section{Nonrenewable Resources}

The most important nonrenewable resources in south Louisiana are minerals: petroleum and natural gas primarily, but also salt and salt brine, shell and other fill materials, sulfur, clay, gravel and sand, lime, and carbon black. Figure VIII-C-2 shows the geographic distribution of these minerals in the study area. Note that petroleum and natural gas are the leading minerals in the entire study area. 


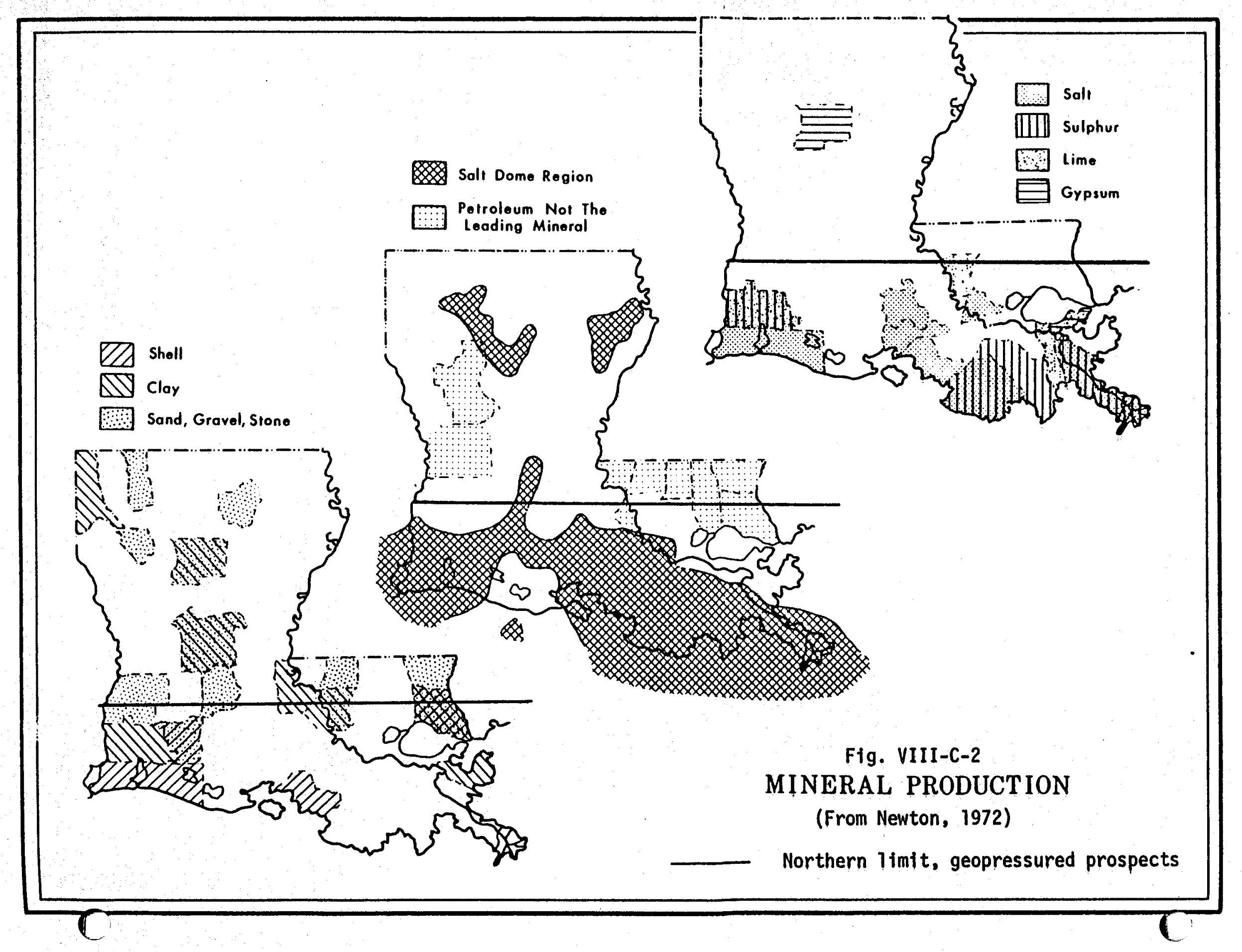


The oil and gas resources of Louisiana are not only vital in terms of national interests: Louisiana produces $1 / 4$ of the 011 and $1 / 3$ of the natural gas produced domestically, but also a major source of income to the State. Severance taxes are just one measure of this economic impact. 011 and gas accounted for over $\$ 500$ million in severance taxes paid in 1976--90\% of all severance taxes paid for mineral extraction (La. State Planning office, 1977). Table VIII-C-2 lists the parishes in the study area and their ranks in terms of severance tax collections. Asterisks denote those parishes in which prime geopressured prospect areas are located (top ranked 20 of 63 prospects).

It. is clear from the table that prime geopressured prospects coincide with major hydrocarbon producing parishes. Protection of $0 i 1$ and gas reservoirs is an area of concern to the State, as evidenced by proposed regulations on the disposal of spent geopressured brines. The requirement is to dispose of brines in aquifers with no connection to oil and gas producing sands (Harre11, 1978; Chauviere, personal communication, 1977).

\section{Cultural Resources}

There are a number of areas of historical, archeological and ecological importance within the study area. With the exception of three sites in Cameron Parish in the southwestern portion of the study area, the majority of the buildings and areas listed in the National Register of Historic Places are in urban areas: New Orleans, Baton Rouge, and Lafayette and several smaller communities. Archeological sites, however, are scattered throughout the area of interest for geon pressured development, and are much more likely to be impacted by geopressured operations. 
TABLE VIII-C-2. Parishes in the geopressure prospect area by rank of 1976 severance tax collertions. (Adapted from La. State Planning Office, 1977).

Parish

Plaquemines

*Terrebonne

*St. Mary

Lafourche

*Iberia

*Vermilion

*Cameron

St. Charles

Jefferson

Acadia

Jefferson Davis

*st. Martin

*Assumption

* Calcasieu

Iberville

St. Landry

Evangeline

St. Bernard

Pointe Coupee

Ascension

St. James

Beauregard

St. John the Baptist

Allen

West Baton Rouge

East Baton Rouge

St. Tammany

Livingston

Tangipahoa

Orleans

aTotal number of parishes ranked: 64

* Location of top 20 ranked geopressured prospects
Rank $^{\mathrm{a}}$

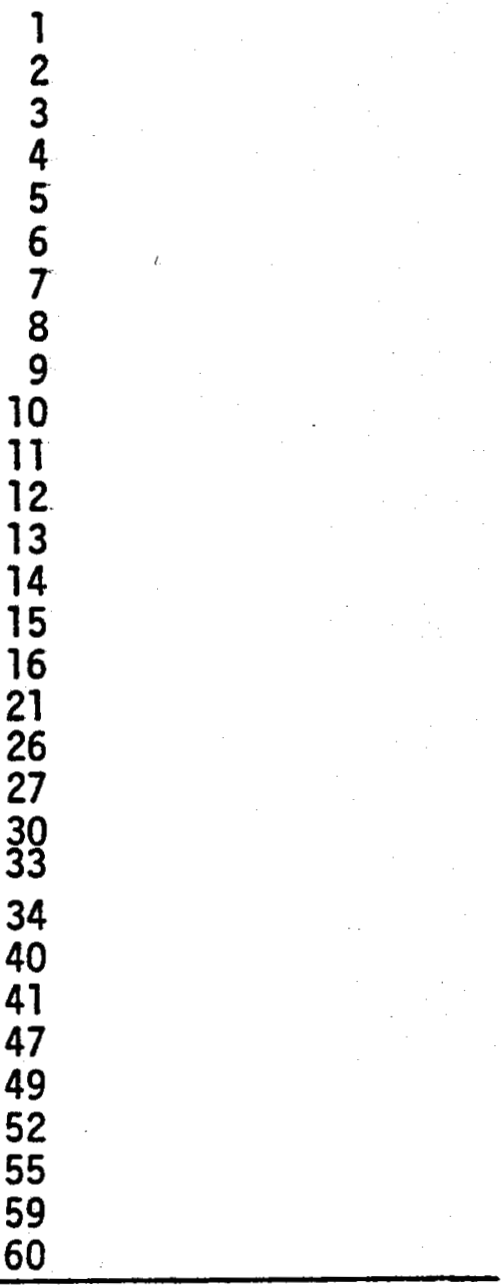


Figure VIII-C-3 shows the distribution of archeological sites in the southern portion of the study area. Archeologists have recorded 446 archeological sites in the marsh areas (Neuman, 1977): Most of these sites are shell middens dating from Paleo-Indian times through historic times; but mounds, camp areas, and village sites are also present. Most of the archeological sites in the coastal marshes have not been investigated. Because of rapid disappearance of the sites due to natural causes and human activity, the value of those that remain has become more apparent. Geopressured development will have to be undertaken so that archeological sites can be preserved or at least excavated. Archeological surveys should be performed before development activities begin.

Areas of ecological interest were discussed as areas of recreational activity in Section VIII-A-4, above. It should be noted that these areas are extensive in the coastal region--the most fragile ecosystems with respect to geopressured development. Wildlife management areas and refuges in south Louisiana total over 700,000 acres. In Cameron Parish, national wildlife refuges comprise $15 \%$ of the total 1 and area in the Parish (U. S. Army Corps of Engineers, 1976).

\section{Coastal Resource Management}

The Louisiana State Planning Office, with grants from the Coastal Zone Management Act of 1972, has compiled a data base in anticipation of the development of a coastal zone management plan for Louisiana. Studies in that data base that compile resource inventories or that deal specifically with the planned integration of resource uses are listed below. Several other pertinent studies are also listed.

Burk \& Associates, Inc., Louisiana Coastal Resources Inventory, V01. 1, Geographic Areas of Particular Concern: New Orleans, Burk \& Associates, Inc., June, 1975. An inventory by parish 
Fig. VIII-C-3. Distribution of archeological sites, coastal Louisiana, (From U.S. Army Corps of Engineers, 1976).

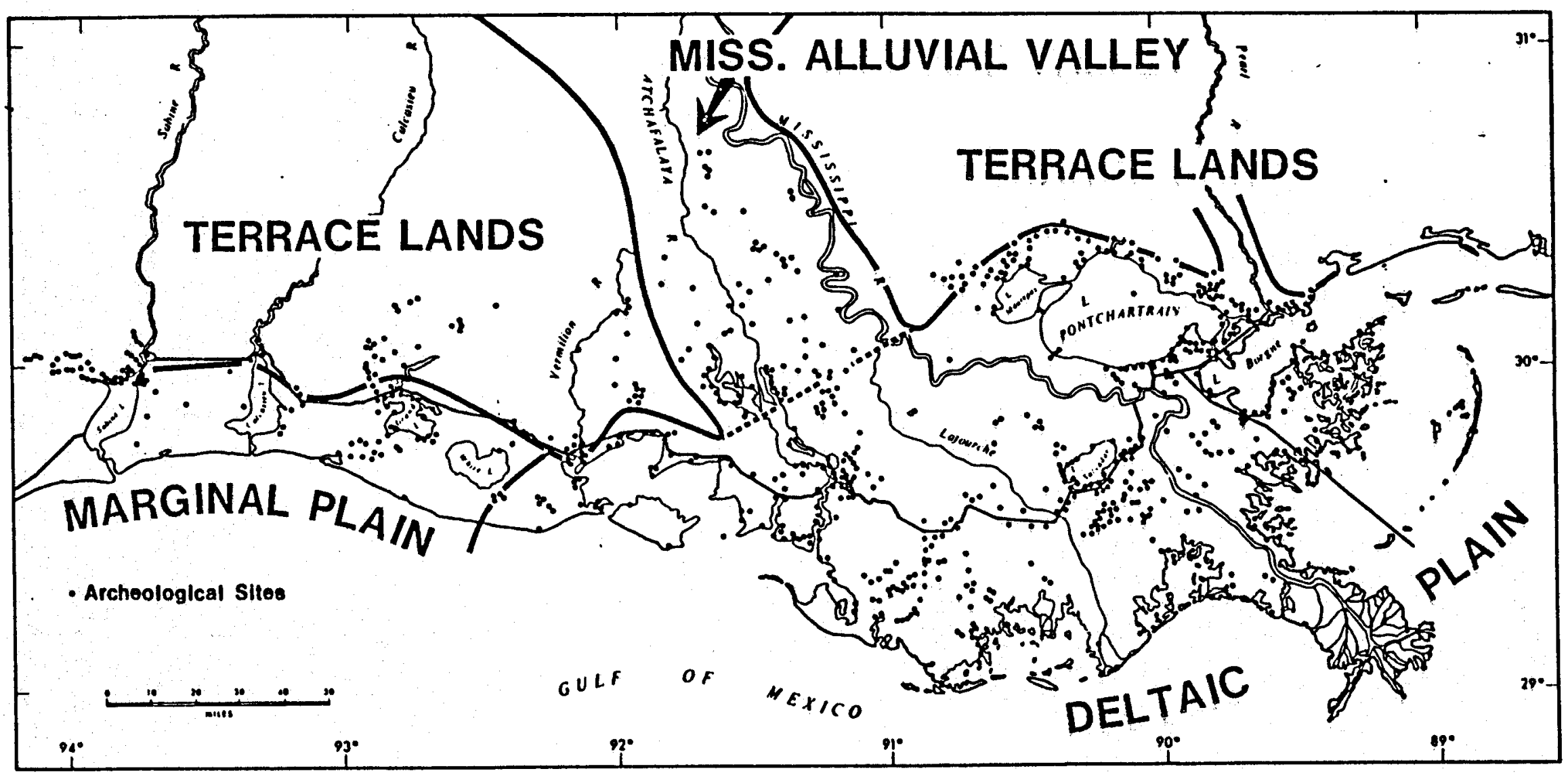

: 
(questionnaires were used) including recreational facilities, historical, cultural, and tourist features, archaeological sites, and development areas of particular concern.

Burk \& Associates, Inc., Louisiana Coastal Resources Inventory, Volume 2, Impact Assessment Review: New Orleans, Burk \& Associates, Inc., June, 1975. An inventory of federal, state, regional and metropolitan agencies and their plans and projects which affect the coastal zone.

Burk \& Associates, Inc., Louisiana Coastal Resources Inventory, Volume 3, Significant Coastal Plans and Projects: New Orleans, Burk \& Associates, Inc., June, 1975. An analysis of completed, under construction and proposed projects which may have a significant impact on the coastal area.

Burk \& Associates, Inc., Louisiana Coastal Resources Inventory, Volume 4, Parish Maps: New Orleans, Burk \& Associates, Inc., 1977.

1. Recreational sites

2. Historic and cultural features

3. Archeological sites

4. Developmental areas

5. Unique ecological features

6. Vegetation

7. Flood prone areas and elevation

8. Hydrologic Characteristics ground water and surface water quality

9. Soil subsidence potential

10. Land loss potential due to channel construction

11. Prime agricultural and forestry lands

12. Existing and future land use

13. Recreational potential

14. Natural land suitability maps

$1: 500,000$

$1: 500,000$

$1: 500,000$

$1: 500,000$

$1: 500,000$

$1: 125,000$

$1: 125,000$

$1: 125,000$

$1: 125,000$

$1: 125,000$

$1: 125,000$

$1: 125,000$

$1: 500,000$

$1: 125,000$

Does not include the following parishes in the study area: Allen, Acadia, East Baton Rouge, Evangel ine, Beauregard, Lafayette, St. Landry and West Baton Rouge.

Burk \& Associates, Inc., Potential Preservation and Restoration Areas in the Louisiana Wetlands: New Orleans, Burk \& Associates, Inc., June, 1977. This report considers fifty potential natural areas representing a cross section of all major physiographic types in coastal Louisiana which were evaluated as natural areas. The evaluations are addressed in this report under three headings: (1) Standards and Criteria for Preservation and Restoration Areas; (2) Evaluation of Potential Preservation Areas; and (3) Priority Ranking of Preservation Areas. Two maps depicting potential restoration areas and potential preservation areas are included. 
Burk \& Associates, Inc., Recreational Potential Along the Louisiana Coast: Proposed New and Expanded Sites for Recreation: New Orleans, Burk \& Associates, Inc., February, 1977. Lists, arranged by parish, containing recommendations for both expansion of existing facilities and new potential sites in areas where facilities are now non-existing along the Louisiana coast.

Coastal Environments, Inz., A Process for Coastal Resources Management \& Impacts Assessment: Baton Rouge, Coastal Environments, Inc., August, 1976. Presents a background for understanding resource management and an overview of naturally occurring and manmade physical conditions that may be encountered in the Louisiana coastal area. Also, it presents a practical procedure for developing a local coastal resource management program and a systematic approach to resource management and assessment of onshore impacts resulting from outer continental shelf energy related resource development.

U. S. Army Corps of Engineers, Engineer Agency for Resources Inventories, Inventory of Basic Environmental Data, South Louisiana, Mermentau River to Chandeleur Sound, with Special Emphasis on the Atchafalaya Basin. Washington, D.C.: U. S. Army Engineer Topographic Laboratories. Large sized maps at scale 1:500,000 plus tables. Catagories include water resources, cultural elements, and biological elements. Land use maps at 1:125,000 included.

Larimore, P. B., et al., Louisiana Census Data Atlas: Baton Rouge, Louisiana State Planning Office, 1976. Organization of 1970 census data into atlas format with SYMAP program used in rendering maps. Tabular data included with map.

Midboe, Kai D. et al., Legal Authorities for Control of Land Use in Coastal Louisiana: Baton Rouge, Sea Grant Legal Program, Louisiana State University, November, 1976. A detailed description of the federal, state and local authorities to regulate activities within Louisiana's coastal zone.

Mumphrey, Anthony J., etal., Coastal Zone Management in the Metropolitan New Orleans Region: New Orleans, Urban Studies Institute, University of New Orleans, August, 1976. A study intended to provide information of several dimensions for use in the development of Coastal Zone Management Plans in the parishes of the metropol itan New Orleans region--Jefferson, Orleans, St. Bernard and St. Tammany--in an attempt to lead to judicious utilization of the resources in the Louisiana coastal zone. 
Mumphrey, Anthony J., et al., OCS Development in Coastal Louisiana: A Socio-Economic Impact Assessment: New Orleans, Urban Studies Institute, University of New Orleans, August, 1977. This study quantifies the impacts of OCS development activities in terms of economic production, jobs, population, and public service. costs. Also discussed are the federal Coastal Energy Impact Program, the additional costs of urban development in wetlands, local planning capabilities in the coastal zone and citizen involvement in coastal planning.

Mumphrey, Anthony J., et al., Urban Development in the Louisiana Coastal Zone: Problems and Guidelines: New Orleans, Urban Studies Institute, University of New Orleans, December, 1976. A study surveying existing urban development practices in Louisiana's coastal zone, identifying problem areas in wetlands development, and assesses the adequacy mechanisms.

Murray, S. P., Projected Parish Land Needs: Baton Rouge, Coastal Resources Program, Louisiana State Planning Office, Apri1, 1977. Inventories of existing and coastal land needs by coastal parish. A brief outline of existing land utilization is compared by projected demands for selected land needs through 1985.

Renner, James R., The Coastal Zone: An Overview of Economic, Recreational and Demographic Patterns: Baton Rouge, Louisiana State Planning Office, November, 1976. A general perspective on the uses, categorized, as economic, demographic and recreational, of the physical resources of the coastal zone, both renewable and nonrenewable.

In addition, the Louisiana State Planning Office has developed a computer oriented planning information system, the Comprehensive Planning Information System (CPIS). Socioeconomic and demographic data from the Census Bureau Summary Tapes, and information from state and municipal agencies, and statistical programs have been placed into CPIS. Land use data has been assembled using the Land Use and Data Analysis (LUDA) program prepared by the U. S. Geological Survey. Louisiana is one of the first states to get access to this program slated for nationwide use within the next decade. With the LUDA program are land use overlays keyed to standard USGS topographic maps at scales ranging from 1:500,000 to 1:62,500. Thus far, LUDA has been used for such purposes 
as identifying industrial site locations, updating city and parish land use maps, and in reviewing environmental impact statements. LUDA would appear to be a useful tool in providing and organizing data appropriate for a small scale baseline land use study. 


\section{NATURAL HAZARDS}

Many of the natural hazards in south Louisianan that could affect the construction and operation of geopressured facilities are associated with recurring meteorological events. These include hurricanes and accompanying storm surges, fresh-water flooding, tornadoes, thunderstorms and lightning, freezing weather, and fog. Although some of these events, due to their potential destructiveness and/or relative frequency, constitute greater threats than others, they all represent conditions that might cause delays and shut-ins. Hurricane and other gale force winds and accompanying storm surges could endanger the lives of personnel at geopressured facilities. Fortunately, the oil and gas industry in south Louisiana has gained considerable experience. in protecting life and equipment from these natural occurrences. A geopressured industry should be no different in this respect.

of greater concern, however, is the potential for increasing the area prone to flooding should subsidence occur as a result of geopressured operations. The coastal region would be particularly vulnerable in this event. Subsidence effects could impact a large area, because the coastal marshes are at very low elevations and there is little relief in the region. The coastal marshes buffer the effects of storms, so loss of marsh due to subsidence could increase storm hazards for coastal communities. In more upland portions of the study area, subsidence in the vicinity of streams subject to fresh-water flooding could extend flood prone areas. 
An impact such as flood damage to communities due to subsidence during geopressured operations represents a worst case situation. As discussed fully in Section. IV, subsidence cannot be predicted at this time--either its occurrence or the amount of subsidence--in geopressured development. However, it is important to review the environmental setting of the study area with respect to this possible impact. Meteorological events of concern in terms of both flooding hazards and damage to geopressured facilities are discussed below.

\section{Hurricanes and Accompanying Storm Surges}

The possibility of a hurricane or tropical storm entering the south Louisiana region is the greatest natural threat to human activity and the environment. The destructiveness of a hurricane arises not only from its strong winds, with speeds of up to $320 \mathrm{~km} / \mathrm{hr}(200 \mathrm{mph})$, but also from the surge of seawater pushed ahead of the storm by the intense counterclockwise circulation about its center. Storm surges on the Mississippi Gulf Coast during Hurricane Camille (1969) reached as high as 7 meters (23 feet) (U.S. Army Corps of Engineers, 1970). Figure VIII-D-1 shows the extent of flooding in coastal Louisiana from Hurricane Audrey in June 1957. In an average hurricane, hurricane force winds (over $120 \mathrm{~km} / \mathrm{hrs}$ ) extend in a $160 \mathrm{~km}$ (100 mi) diameter around the central eye; and gale force winds $(60-120 \mathrm{~km} / \mathrm{hr})$ extend about $560 \mathrm{~km}$ (350 mi) from the storm center (Dunn and Miller, 1960). Thus, while areas directly in the track of the storm often suffer heavy losses in human lives and property, a hurricane can effect destruction over a relatively wide area. The damage caused by Hurricane Camille totaled over one billion dollars, $\$ 500$ million of it in the Gulf Coast area; along with the loss of 262 lives, including 137 in Mississippi and 9 in Louisiana (U.S. Army Corps of Engineers, 1970). 


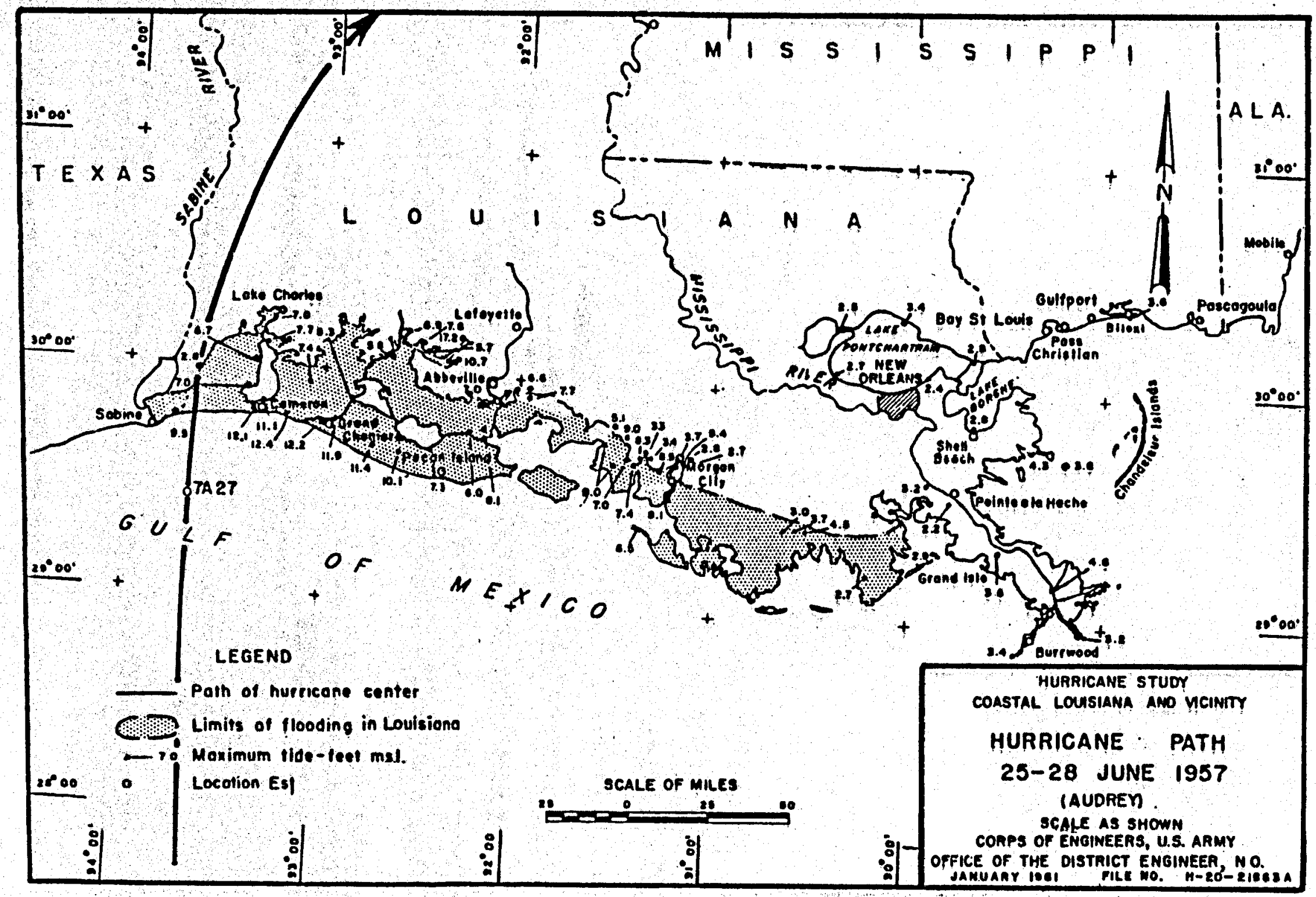

Fig. VIII-D-1. Flooding from storm surge during Hurricane Audrey. 
From 1900-1976, 36 hurricanes crossed the Louisiana coast or passed close enough to inflict damage: a return period of about once every 2 years. The National Weather Service has kept records of the meteorological details of these storms as well as general information as to losses (NWS, Hurricane Center, Miami, Florida). More thorough reports on major hurricanes are compiled by the U.S. Army Corps of Engineers (Camille, 1970; Betsy, 1966; Audrey, 1958). The Corps have also organized a history of hurricanes and tropical storms in coastal Louisiana with breakdowns according to area and extent of damages (U.S. Army Corps of Engineers, 1972).

Local and regional authorities, working in cooperation with federal agencies such as the Corps of Engineers and the National Weather Service Hurricane Center in Miami, have constructed levees and other structures for hurricane protection and devised a forecast warning network as well as a plan of emergency procedures to follow in the event of a hurricane. General precautions often include an evacuation of offshore facilities and low-lying coastal areas, and a shutdown of vulnerable drilling operations.

Hurricanes occur only in summer and fall: the official hurricane season lasts from June .1 - November 30 . The peak month is September.

2. Fresh Water Flooding

The potential flooding of the Lower Mississippi River Basin represents a grave hazard in south Louisiana. One of the world's largest river systems, the Mississippi and its tributaries drain over 
2.59 million $\mathrm{km}^{2}$ ( 1 million $\mathrm{mi}^{2}$ ), with an annual discharge through Louisiana that averages almost 450,000 million gals/day $(700,000 \mathrm{cfs})$. Flood conditions are brought about by excessive winter and spring precipitation and resultant runoff throughout the various sub-basins of the Mississippi River, such as the Ohio, Tennessee, and Arkansas River basins. Peak flood stages in Louisiana usually occur in late winter and early spring and sometimes persist into late spring.

In 1927 the most devastating flood of this century happened in the Lower Mississippi River Valley. Over $28,000 \mathrm{~km}^{2}\left(11,000 \mathrm{mi}^{2}\right)$ of Louisiana land was inundated and over $\$ 200$ million in property damage was sustained. The flood began in January and lasted into July for a total of 180 days (Frankenfield, et. a1., 1927). As a result of this disaster, a massive program for the management of the entire Mississippi River system was begun, implemented by the U.S. Army Corps of Engineers. By the late 1960's the plan had been substantially completed and had involved the construction of artificial l Jevees, floodways, ups tream reservoirs, and other control structures.

The flood of 1973, which came close to matching the 1927 flood, caused relatively much less damage in Louisiana, thanks to this control system (Chin, et. al,, 1975). Nevertheless, a great deal of concern was expressed after this flood. The controls, designed to handle a project flood somewhat larger than the 1973 flood, had been taxed to their limits. Improvements in flood control structures have been initiated. 
Flooding of local streams usually results from intense local precipitation of several days duration. Because of the small watersheds, flood stages are quickly reached and no more than a few days flood warning is possible. The meteorological situation necessary to produce storms of this type recur rarely at the same location, but tend to be spring weather events. The flood on the Amite River in 1977, in which the river stage at Denham Springs, Louisiana reached almost 0.6 meters ( 2 feet) above record flood levels, resulted from an intense four day rain during which over $30 \mathrm{~cm}$ (12 in) of water fell at several sites within the watershed (U,S,G,S.., 1977). Data on Louisiana floods can be found in Neely (1976).

Storm rainfall capable of causing local flooding is sometimes associated with tropical disturbances such as hurricanes. This type of flooding should be distinguished from the flooding caused by storm surges.

\section{3. . Tornadoes}

Tornadoes, the most violent of all meteorological phenomena, have been sighted in all sections of Louisiana, but appear to have their greatest frequency in the northwest part of the state. They have been reported during al1 months of the year with about 50 per cent of the total number (444 from 1916-1968) occurring from February through May. Peak tornado activity has been in April, and a secondary peak comes in November. Louisiana storms show a tendency to occur in the afternoon and early evening (Cry, 1969). 
Most tornadoes evolve out of intense thunderstorms and squall Iines that form in the warm sector adjacent to winter and spring cold fronts. Somewhat less severe, but nonetheless dangerous tornadoes are often spawned by hurricanes (Novlan and Graw, 1974). The most damaging Louisiana tornadoes, at Minden in May 1933, and at Larose in October 1964, claimed 23 and 22 lives, respectively. The Larose storm was associated wi th Hurricane Hilda.

The return period for tornadoes at a given point in Louisiana is about once in 1100 years (Cry, 1969). It should be noted that the number of tornadoes reported is almost certainly somewhat less than the actual number of occurrences as many tornadoes touch down in relatively uninhabited areas. Responsibility for tornado warnings lies with the Severe Storms Center of the National Weather Service in Kansas City, Missouri.

\section{Thunderstorms and Lightning}

South Louisiana experiences an average of between 65 and 75 thunderstorm days per year--that is, days wi th thunder heard at a first-order weather station (Court, 1973). Summer is the peak season with about 40 days; and winter, the minimum with between 5 and 10 days (U.S. Weather Bureau, 1965). The summer storms are of a convective type and usually not associated with frontal activities as are storms in other seasons. Thunderstorms also develop within the circulation of hurricanes.

Lightning accompanies al1 thunderstorms. In a seven year period between 1959 and 1965, lightning killed 16 persons in south Louisiana (Zegel, 1967). 
5. Freezing Weather and Fog

The occurrence of freezing temperatures (below $0^{\circ} \mathrm{C}$ ) has an adverse effect on agricultural activities and many industrial operations. South Louisiana experiences some days with freezing temperatures every year. There is often a considerable difference in the number of freeze days at coastal versus inland sites due to the moderating effects of the Gulf of Mexico. For example, in the winter of 1969-70 most coastal sites in Louisiana recorded no more than 10 freezes, while an inland site, such as Baton Rouge, had approximately 30 (Muller and Wax, 1977). A publication on freeze probabilities that may be useful in Tong-range planning has been prepared by Cry (1968). Winter and spring are the foggy seasons in south Louisiana; fog is virtually absent in summer and fall. The more typical fog situation occurs when warm, moist air from the Gulf of Mexico flows over the cooler land surface and the water vapor condenses. This is , called advection fog. Radiation fog, which results from overnight cooling of the land surface and the air above it to its dewpoint temperature, also occurs. Smog is not considered a serious problem in Louisiana. 
1

i

IX. REFERENCES 


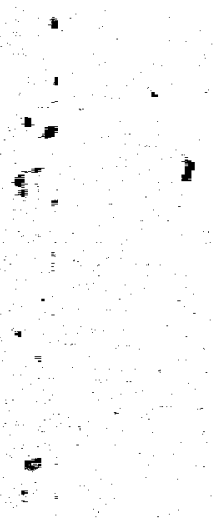

$=$ 


\section{REFERENCES}

Adams, R. D., Barrett, B. B., Gane, B. W., McIntire, W. G., 1976, Barataria Basin: Geologic processes and framework: Louisiana Coastal Resources Program, State Planning Office, Baton Rouge, Louisiana.

Bates, Robert, Chief Geologist, Louisiana Department of Natural Resources, Office of Conservation, personal communication, December 1977.

Bebout, D. G., Agagu, 0. K., and Dorfman, M. H., 1975, Geothermal resources, Frio Formation, middle Texas Gulf Coast: Geol. Circ. 75-8, Bureau of Economic Geology, University of Texas, Austin, Texas, 43p.

Beck, C. B., Cabot Corporation, personal communication, December 1977.

Bernard, William J., Professor, Petroleum Engineering Dept., Louisiana State University, personal communication, December 1977, February 1978.

Bernard, W. J., 1977, Preliminary results of research: Site specific investigations of the geopressure energy resource of southern Louisiana: Petroleum Engineering Dept., Louisiana State University, Baton Rouge, Louisiana.

Bogomolov, Y. C., 1967, Geotemperature regime: Int. Assoc. Scientific Hydrology Bul1., Dec. 1967, p. 86-91.

Brown and Root, Inc., 1976, Gulf Coast geopressured geothermal energy study: Appendix A, Vo1. 2, Proceedings, Second Geopressured-Geothermal Energy Conference, Center for Energy Studies, University of Texas, Austin, Texas.

Burst, J,F., 1969, Diagenesis of Gulf Coast clayey sediments and its possible relation to petroleum migration: Am. Assoc. Petro. Geol. Bul1., Vol. 53, No. 1, p. 73-93.

Byrne, P., Borengasser, M., Orew, G., Muller, A. A., Smith, B, L., Jr., Wax, C., 1976, Barataria Basin, hydrologic and climatologic processes: Center for Wetland Resources, Louisiana State University, Baton Rouge, Louisiana.

Chabreck, R, H, 1970, Marsh zones and vegetative types in the Louisiana marshes: Ph.D. Dissertation, Louisiana State University, Baton Rouge, Louisiana, unpubiished.

Chabreck, R. H., 1972, Vegetation, water and soil characteristics of the Louistana Coastal region: Bulletin No. 664, Agricultural Experiment Station, Louisiana State University, Baton Rouge, Louisiana. 
Chauviere, Arnold, Assistant Commissioner of Conservation, Louisiana Department of Natural Resources, Office of Conservation, personal communication, December 1977.

Chin, E. H., et.al., 1975, The 1973 Mississippi River Basin flood: Compilation and analyses of meteorological, streamflow, and sediment data: U. S. Geological Survey, Professional Paper No. 937, Government Printing Office, Washington, D. C.

Christopher, Robert, Director of Research, United Gas Pipeline Company, personal communication, November 1977.

Coerver, James F., Director, Louisiana Department of Health and Human Resources, personal communication, December 1977.

Court, A., 1973, The climate of the conterminous United States: in Bryson, R. A., and Hare, F. K., eds., Climates of North America, Elsevier Publishing Co., Amsterdam, The Netherlands.

Craig, N. J., Turner, R. E., Day, J. W., Jr., 1977, Cumulative impact studies in the Louisiana coastal zone, Part II: Land 1oss: Louisiana Coastal Resources Program, State Planning Office, Baton Rouge, Louisiana.

Cry, G., 1968, Freeze probabilities: Louisiana, Cooperative Extension Service, Baton Rouge, Louisiana.

Cry, G., 1969, Louisiana tornado record 1916-1968: mineographed copy, Department of Geography and Anthropology, Louisiana State University, Baton Rouge, Louisiana.

Dunn, G. E., and Miller, B. I., 1960, Atlantic hurricanes: Louisiana State University Press, Baton Rouge, Louisiana.

Durham, Clay 0., President, Magma Gulf Company, personal communication, December 1977.

Evans, D. M., 1970, The Denver area earthquakes and the Rocky Mountain Arsenal disposal wel1: Engineering Seismology: The works of man: Engineering Geology Case Histories, No. 8, p. 25-32.

Everette, Chuck, DOE Operations Manager, Bayou Choctaw Strategic Petroleum Reserve Program, personal communication, March 1978.

Fielder, E. R., and Harrison, D. P., 1977, The impact of fuel switching on Louisiana air quality: Louisiana Department of Natural Resources, Office of Conservation, Baton Rouge, Louisiana.

Frankenfield, H. C., et.al., 1927, The floods of 1927 in the Mississippi Basin: Monthly Weather Review, Supplement No. 29, Government Printing Office, Washington, D. C. 
Gabrysch, R. K., and Bonnet, C. W., 1974, Land-surface subsidence in the area of Burnett, Scott, and Crysta1 Bays near Baytown, Texas: U. S. Geological Survey, Water-Resources Inventory, 21-74, 48p.

Gabrysch, R. K., and Bonnet, C. W., 1975, Land-surface subsidence in the Houston-Galveston region, Texas: Report No. 188, Texas Water. Development Board, 19p.

Gagliano, S. M., and van Beek, J. L., 1970, Geologic and geomorphic aspects of deltaic processes, Mississippi delta system: Hydrologic and Geologic Studies of Coastal Louisiana, Report No. 1, Center for Wetland Resources, Louisiana State University, Baton Rouge, Louisiana.

Gambolati, G, 1977, Stress-strain analys is in three-dimensional pumped aquifers by the finite element method: Finite Elements in Water Resources, Proceedings, First International Conference on Finite Elements in Water Resources, Pentech Press, London.

Geertsma, J., 1973, Land subsidence above compaction oil and gas reservoirs: J. Pet. Tech., Vol. 25, p. 734-744.

Gosselink, J. G., et.al,, 1974, The value of the tidal marsh: Sea Grant Publ. No. LSU-SG-74-03, Center for Wetland Resources, Louisiana State University, Baton Rouge, Louisiana.

Gulf States Utility Company, 1973, River Bend Station Units $1 \& 2$, preliminary safety analysis report, Vol. 1: Gulf States Utility. Company, Beaumont, Texas.

Gupta, S. K., Tanji, K. K., and Luthin, J. N., 1975, A three-dimensional finite element groundwater mode1: Contribution Series No. 152, Water Resources Center, University of California.

Gustavson, T. C. and Kreitler, C. W., 1976, Geothermal resources of the Texas Gulf Coast: Environmental concerns arising from the production and disposal of geothermal waters: Bureau of Economic Geology, University of Texas, Austin, Texas.

Gustavson, Thomas C., Bureau of Economic Geology, University of Texas, personal communication, November 1977.

Haimson, B. C., 1977, Recent in situ stress measurements using the hydrofracturing technique: Proceedings, 18th U. S. Symposium on rock mechanics: Energy resources and excavation technology, Johnson Publishing Co., Boulder, Colorado.

Hankins, B. E., Ham, R. A., Chavanne, R. A., and Karkalits, O. C., 1978, Chemical analyses of geothermal waters from a south Louisiana well: Proceedings, Third Geopressure-Geothermal Energy Conference, University of Southwes tern Louisiana, Lafayette, Louisiana, Nov. 16-18, 1977, in press. 
Harre11, Thomas A., Professor, Law Center, Louisianà State University, personal communication, January 1978.

Harrell, T. A., 1978, Legal problems in the development of geopressured resources in Louisiana: Report submitted to Division of Geothermal Energy, U. S. Department of Energy, Washington, D. C.

Hawkins, M. F., Jr., 1977, Investigations on the geopressure energy resource of southern Louisiana: Final Report, ERDA Contract EY-76-S05-4889, Petroleum Engineering Department, Louisiana State University, Baton Rouge, Louisiana.

Herring, Joe, Chief, Game Division, Louisiana Department of Wildlife and Fisheries, personal comunication, December 1977.

Holdahl, S. R., and Morrison, N. L., 1974, Regional investigations of vertical crustal movements in the $U$. $S$. using precise relevelings and mareograph data: Tectonophysics, Vol. 23, p. 373-399.

Holzworth, G. C., 1972, Mixing heights, wind speeds, and potential for urban air pollution throughout the contiguous United States: Government Printing office, Washington, D. C.

Hornburg, C. D., 1975, Geothermal resource utilization--Paper and cane sugar industries: Proceedings, First Geopressured/Geothermal Energy Conference, Center for Energy Studies, University of Texas, Austin, Texas, p. 233-262.

Hsu, S. A., 1976, Atmospheric dispersion characteristics in the Louisiana coastai zone: Sea Grant Publication No. LSU-T-76-011(t), Center for Wetland Resources, Louisiana State University, Baton Rouge, Louisiana.

Huggett, G. R., and Slater, L. E., Precision electromagnetic distancemeasuring instrument for determining secular strain and fault movement: Tectonophysics, Vol. 29, 1975.

Hunt, T. M., 1970, Gravity changes at Wairakei geothermal field, New Zealand: Geol. Soc. America Bul1., Vol. 81, p. 529-536.

Jones, P. H., 1969a, Hydrodynamics of geopressure in the northern Gulf of Mexico Basin: J. Petroleum Technology, Vol. 21, No. 7, p. 803-810.

Jones, P. H., 1969b, Hydrology of Neogene deposits in the northern Gulf of Mexico Basin: Louisiana Water Resources Institute, Bulletin GT-2, 105p.

Jones. P. H., 1975, Geothermal and hydrocarbon regimes, Northern Gulf of Mexico Basin: Proceedings, First Geopressured-Geothermal Energy Conference, Center for Energy Studies, University of Texas, Austin, Texas, p. 15-89. 
Karkalits, 0. C., Professor, Chemistry Department, McNeese State University, personal communication, November 1977.

Karkalits, O. C., and Hankens, B. E., 1978, Chemical analysis of gas dissolved in geothermal waters in a south Louisiana well; Proceedings, Third Geopressure-Geothermal Energy Conference, University of Southwestern Louisiana, Lafayette, Louisiana, Nov. 16-18, 1977, in press.

Kazmann, R. G., and Heath, M. M., 1968, Land subsidence related to ground water offtake in the New Orleans area: Transactions, Gulf Coast Association of Geological Societies, Vol. 28, p. 108-113.

Kruger, $P_{.}$, and Otte, C., 1973, Geothermal energy: Stanford University Press, Palo Alto, California.

Lafleur, Robert, Secretaty, Stream Control Commission, Louisiana Department of Wildlife and Fisheries, personal communication, November 1977.

Lewis, Anthony J., Associate Professor, Department of Geography and Anthropology, Louisiana State University, personal communication, December 1977.

Lofgren, B. E., 1977, Background studies for appraising subsidence in the Texas Gulf Coast region: U. S. Geological Survey, Open-File Report No. 77-412, 28p.

Louisiana Air Control Commission 1976, Ambient air data: Annual Report, Louisiana Air Control Commission, New Orleans, Louisiana.

Louisiana Department of Natural Resources, Office of Conservation, 1978, Proposed Statewide Order No. 29-P: Department of Natural Resources, Baton Rouge, Louisiana.

Louisfana Department of Public Works, 1969, Present municipal water use in Louisiana: Series 1, Vol. 1, Louisiana Dept. of Public Works, Baton Rouge, Louistana.

Louistana Department of Wildlife and Fisheries, 1972, 14th Biennial Report, 1970-71: Louisiana Department of Wildiffe and Fisheries, New Orleans, Loutsiana.

Louisiana Revised Statutes 30:802: West Annotated Publication, 1950. Louisiana Revised Statutes 56:1451: West Annotated Publication, 1950.

Louisiana State Planning Office, 1977, The State of the State in 1977: An economic and social report to the Governor: Louisiana State Planning Office, Baton Rouge, Louisiana.

Louisiana Stream Control Commission, 1977, State of Louisfana: Water Quality Criteria: Louisiana Stream Control Commission, Baton Rouge, Louisiana. 
Louisiana Stream Control Commission, 1978, Location of LSCC water quality stations: available from Louisiana Stream Control Commission, Baton Rouge, Louisiana.

McIntire, W. G., et.al., 1975, A rationale for determining Louisiana's coastal zone, Report No. 1, Coastal Zone Management Series: Sea Grant Publication. No. LSU-T-75-006, Center for Wetland Resources, Louisiana State University, Baton Rouge, Louisiana.

Minott, J. D., Ashland Chemical Company, personal communication, January 1978.

Muller, R. A., 1975, Freshwater potential in the Louisiana coastal marshes and estuaries: Geoscience and Man, Vo1. 12, June 20, 1975, p. 1-7.

Muller, R. A., 1977, A synoptic climatology for environmental baseline analysis: New Orleans: Journal of Applied Meteorology, Vol. 16, No. 1, p. 20-33.

Muller, R. A., and Wax, C. L., 1977, A comparative synoptic climatic baseline for coastal Louisiana: Dept. of Geography and Anthropology, Louisiana State University, Baton Rouge, Louisiana, unpublished.

Muller, R. A., and Wax, C. L., 1978, A comparative synoptic climate baseline for coastal Louisiana: Geoscience and Man, Vol. 18, p. 121-129.

Murphy, K. E., et.al., 1977, Soil survey of Lafayette Parish, Louisiana: Soil Conservation Service, U. S. Department of Agriculture, in cooperation with Louisiana Agricultural Experiment Station, Louisiana State University, Baton Rouge, Louisiana.

Murray, G. E., 1961, Geology of the Gulf and Atlantic coastal province of North America: Harper \& Bros., New York, 629 p.

Neely, B. L., 1976, Floods in Louisiana: magnitude and frequency, 3rd edition: Louisiana Department of Highways, Baton Rouge, Louisiana.

Neuman, R. W., 1977, An archaeological assessment of coastal Louisiana: Mélanges, No. 11, March 21, 1977, Museum of Geoscience, Louisiana State University, Baton Rouge, Louisiana.

Newton, M. B., Jr., 1972, Atlas of Louisiana: Miscellaneous Publication No. 72-1, School of Geoscience, Louisiana State University, Baton Rouge, Louisiana.

Noble, R. E., Professor, Forestry and Wildlife Management, Louisiana State University College of Agriculture, personal communication, November 1977.

Novlan, D. J., and Graw, W. M., 1974, Hurricane spawned tornadoes:

Monthly Weather Review, Vol. 102, p. 476-488. 
O'Ne11, T., and Linscombe, $G_{.}, 1976$, The fur animals, the alligator, and the fur industry in Louisiana: Wildlife Education Bulletin No. 106, Louisiana Wildlife and Fisheries Commission, Baton Rouge, Louisiana.

PapadopuTos, S. S., et.al., 1975, Assessment of onshore geopressuredgeothermal resources in the northern Gulf of Mexico basin: Assessment of Geothermal Resources of the United States-1975, Geological Survey Circular 726, U. S. Geological Survey, Arlington, Virginia.

Pielou, E. D., 1975, Ecological diversity: Wiley-Interscience, New York, 165 p.

Pile, R. S., et.al., 1978, Agricultural uses of waste heat; Proceedings, Third Geopressure-Geothermal Energy Conference, University of Southwestern Louisiana, Lafayette, Louisiana, Nov. 16-18, 1977, in press.

Radian Corporation, 1976, Interim report on air monitoring at nine locations in southern Louisiana: Radian Corporation, Austin, Texas.

Raleigh, C. B., 1972, Earthquakes and fluid injection: Underground waste management and environmental implications: Am. Assoc. Petrol. Geol., Mem. No. 18, p. 273-279.

Reed, Robert, Amoco $0 i 1$ Company, personal communication, November 1977.

Rust, Robert E., Vice President for Exploration, System Fuels, Inc., personal communication, December 1977.

St. Amant, Lyle, Assistant Secretary, Louisiana Department of Wildlife and Fisheries, personal communication December 1977.

St. Amant, Lyle S,, 1971, Impacts of oil on the Gulf Coast: Wildlife Management Institute, Washington, D. C.

Schnadelbach, T. W., Jr., 1977, Inventory and case studies of Louisiana, non-electric industrial applications of geopressured-geothermal

resources: ERDA Contract EG-77-C-07-1629, deLaureal Engineers, Inc., New Orleans, Louisiana.

Schwertz, E. L., Jr., and Larimore, P. B., Jr., 1976, Louisiana planner's mapping guide: State Planning Office, Baton Rouge, Louisiana.

Segerlind, L. J., 1976, Applied Finite Element analysis: John Wiley \& Sons, Inc., New York.

Smith, C, G., Jr., and Kazmann, R. G., 1978, subsidence in the Capital Area Ground Water Conservation District: Bulletin No. 2, Capital Area Ground Water Conservation Commission, Baton Rouge, Louisiana.

Smith, Kenneth, Chief, Division of Fisheries, Loulstana Department of Wildlife and Fisheries, personal communication, December 1977. 
Sorrells, Michael, Teledyne Geotech Co., Inc,, personal communication, November 1977.

Stone, J. H., et.al., 1977, Effects of canals on freshwater marshes in coastal Louisiana and implications for management: Paper presented at Symposium on Freshwater Marshes: Present Status, Future Needs,

Feb. 13-16, 1977, Rutgers, State University of New Jersey, New Brunswick, New Jersey; Center for Wetland Resources, Louisiana State University, Baton Rouge, Louisiana.

Templet, Paul, Director, Coastal Resources. Program, State Planning Office; personal communication, November, 1977.

Texas Water Quality Board Standard, Regulation II, Rule 203.

Thoms, R. L., et.al., 1977, Site specific study for possible ongoing salt dome movement: Proceedings, 18th U. S. Symposium on Rock Mechanics, Keystone Colorado, p. 4B6-1 - 4B6-10.

Thoms, Robert, Professor, Institute for Environmental Studies, Louisiana State University, personal communication, February 1978.

Toth, William J., Applied Physics Laboratory, Johns Hopkins University, personal communication, January 1978.

Turner, D., and Busse, A. D., 1973, Users guides to the interactive versions of three point source dispersion programs: PTMAX, PTDIS, and PTMTP: U. S. Environmental Protection Agency, National Environmental Research Center, Research Triangle Park, North Carolina.

U. S., Army Corps of Engineers, 1966, Report on Hurricane Betsy: Corps of Engineers, New Orleans District, New Orleans, Loutsiana.

U. S., Army Corps of Engineers, 1970, Report on Hurricane Camilie: Corps of Engineers, New Orleans District, New Orleans, Louisiana.

U. S., Army Corps of Engineers, 1972, Hurricane study: History of hurricane occurrences along coastal Louisiana: Corps of Engineers, New Orleans District, New Orleans, Louisiana.

U. S., Army Corps of Engineers, 1975, Environmental statement, Gulf Intracoastal Waterway, Petit Anse, Tigre and Carlin Bayous; and Bayou Gross Tete, Louisiana: U. S. Army Corps of Eng., New Orleans, Louisiana.

U. S., Department of Commerce, Bureau of the Census, 1977a, Current population reports: Estimates of the population of Louisiana parishes and metropolitan areas: July 1, 1975 (revised) and 1976 (provisional): Series P-26, No. 76-18, Government Printing Office, Washington, D. C.

U. S., Department of Conmerce, National Oceanic and Atmospheric Administration, National Marine Fisheries Service, 1977b, Louisiana landings, annual summary 1976: Current Fisheries Statistics No. 7222, USDC, Washington, D. C. 
U. S., Department of the Interior, The Geothermal Environmental Advisory Panel, 1977, Guidélines for acquiring environmental baseline data on federai geothermal leases: U.S. Department of the Interior, Menlo Park, California.

U. S., Department of the Interior, U. S. Fish and Wildlife Service, 1975, Threatened or endangered fauna or flora: Federal Register, 40-5 (127), p. 27823-27924.

U. S., Department of the Interior, U. S. Fish and Wildlife Service, 1977, Endangered and threatened wildlife and plants: Federal Register, VoT. 42 , No. 135, July 14, 1977, p. 36421-36431.

U. S., Department of the Interior, U. S. Fish and Wildlife Service, 1978, Endangered species technical bulletin: Vol. III, No. 1, U. S. Department of the Interior, Washington, D. C.

U. S., Environmental Protection Agency, 1973, User's guide for the climatological dispersion model: NTIS No. PB-227 346, EPA, National Environmental Research Center, Research Triangle Park, North Carolina.

U. S., Federal Energy Administration, Strategic Petroleum Reserve Program, 1977a, Environmental impact statement for Bayou Choctaw salt dome: FEA/S-76/346, Federal Energy Administration (DOE), Washington, D. C.

U. S., Federal Energy Administration, Strategic Petroleum Reserve Program, 1977b, Environmental impact statement for West Hackberry salt dome: FEA/S-76/345, Federal Energy Administration (DOE), Washington, D. C.

U. S. Geological Survey, Water Resources Division, 1971-1977, Water Resources Data for Louisiana: multiple nos. of Water Data Reprot, U. S. Geological Survey, Baton Rouge, Louisiana.

U. S. Geological Survey, Water Resources Diviston, 1976, Water Resources Data for Louistana, Water Year 1976; Water Data Report La-76-2, U. S. Geological Survey, Baton Rouge, Louisiana.

U. S. Geological Survey, Water Resources Division, 1977, Water situation in Louisiana, Apri1 1977: U. S. Geological Survey, Baton Rouge, Louisiana.

U. S. Weather Bureau and Federal Aviation Agency, 1965, Aviation weather: Government Printing Office, Washington, D, C.

Waguespack, M., Coordinator, Research project on operations research and systems analysis of geopressured resource development in Louisiana, Office of Advanced Studies and Research, Louisiana State University, personal communication, November 1977. 
White, W. A., McGraw, M., and Gustavson, T. C., 1977, Preliminary environmental analysis of a geopressured-geothermal test well in Brazoria County, Texas: Bureau of Economic Geology, University of Texas, Austin, Texas.

Wilhelm, 0., and Ewing, M. 1972, Geology and history of the Gulf of Mexico: Geol. Soc. Amer. Bull., Vol. 83, p. 575-600.

Wilson, J. S., et.a1., 1977, Environmental assessment of geopressured waters and their projected uses: EPA Report No. 600/7-77-039, Industrial Environmental Research Laboratory, U. S. Environmental Protection Agency, Cincinnati, Ohio.

Wilson, Lewis A., Manager, Advanced Energy Programs Section, Middle South Service, In., personal communication, December 1977.

Wintz, W. A., Jr., Kazmann, R. G., and Smith, C. G., Jr., 1970, Subsidence and Ground water offtake in the Baton Rouge area: Bulletin No. 6, Louisiana Water Resources Research Institute, Louisiana State University, Baton Rouge, Louisiana.

Zegal, F. H., 1967, Lightning deaths in the United States: a sevenyear survey from 1959 to 1965, Weatherwise, Vol. 20, p. 169-173.

Zinn, D. C., Wilkins, B., Waguespack, M., 1978, Preliminary development scenarios for geopressured-geothermal energy resources in Louisiana and Texas: Proceedings, Third Geopressure-Geothermal Energy Conference, No. 16-18, 1977, University of Southwestern Louisiana, Lafayette, Louisiana, in press. 
1014

$X$. APPENDICES

A. Description of Ecosystem Types in the Geopressured Prospect Area, Louisiana

B. Summary of Consultations with Interested Groups 
0

$\sqrt{1}$ 


\section{APPENDIX A}

Description of Ecosystem Types in the Geopressured Prospect Area, Louisiana 


\section{AQUATIC AND WETLAND ECOSYSTEMS}

Marine Ecosystem. The marine ecosystem is defined as a coastal open water system with unobstructed access to the open ocean. The water regimes and water chemistry of this ecosystem are determined primarily by the ebb and flow of oceanic tides. Salinity levels vary from 10,000 to 35,000 milligrams per liter $(\mathrm{mg} / \mathrm{l})$, depending on riverine discharge and distance offshore. The relatively constant marine environment fosters a diversity of plant and animal species. The phytoplankton are predominantly dinoflagellates and diatoms, while benthic algae include primarily Chlorophyta, Rhodophyta, and Phaeophyta. Only four species of marine vascular plants are found in Louisiana waters. Copepoda are abundant in the zooplankton, while benthic macroinvertebrate collections are predominatly polychaetes and molluses, as well as the commercially important penaeid shrimp which spend half their life cycles in the Gulf and half in the estuaries. Other commercially important species are the blue crab and squids. The most important fishes in offshore waters are the Gulf menhaden, croaker, herrings, redfish, seatrouts, spot, anchovies, mullet, sea basses, snappers, drums, and flounders. Again, such abundant species as menhaden, croaker, spot, redfish, and spotted seatrout are estuarine dependant.

Reptiles in the marine environment include five species of sea turtles of which three are on the endangered species list. Marine mammals are also protected and include the dolphin, manatee and several whales. Birds associated with this ecosystem include grebes, loons, cormorants, osprey, Peregrin falcon, gulls and terns. Threatened or endangered species are the state bird--the brown pelican, and possibly several marine mammals and reptiles. 
Estuarine Ecosystem. The estuarine ecosystem is defined as a coastal system, semi-enclosed by land, with open, partially obstructed, or sporadic access to the Gulf and with a measurable quantity of ocean-derived salt in the water. Salinities vary between 500 and $25,000 \mathrm{mg} / 1$. Open water areas of estuarine ecosystems (vegetated regions within this ecosystem are discussed separately) include bays, tidal channels, canals, ponds and lakes. Phytoplankton include diatoms, coccid blue-green algae and coccoid green algae, as well as numerous ultraplankton. Aquatic macroalgae include Chara vulgaris, filamentous greens, Enteromorpha and Ectocarpus. Vascular aquatic plants are species of Ruppia, Lemna, Eichornia, Myriophyllum, Ceratophyllum and Eleocharis. Zooplankton are dominated by cyclopoid copepods and cladocerans, and, at times, ichthyoplankton.

Because of high discharges of fresh-water into these estuarine areas, some typically fresh-water taxa are also found. Macroinvertebrates also range from typically estuarine to typically fresh-water species. Mollusca, polychaetes, oligochaetes, amphipods, decapods and some insects are found in the fauna. Penaeid shrimp use the estuary as a nursery ground and undergo most of their growth and development there. Abundant fishes in the estuary include gulf menhaden, bay anchovey, blue and sea catfish, sheepshead minnow, gulf killifish, mosquitofish, silversides, atlantic croaker, striped mullet, and clown goby; redfish, spotted seatrout and southern flounder are very important sport and comercial species. Reptiles, amphibians, mammals and birds associated with the estuarine ecosystem will be discussed in the section on the saline marsh.

Fresh-water Ecosystems. Fresh-water ecosystems can be divided into three subsystems: palustrine system is defined as aquatic habitats where surface water is not restricted to a definable channel, where wave-formed 
shoreline features are absent, and where open water is less than 4 hectares (10 acres) in extent. This class excludes permanently vegetated regions (i.e. marshes and swamps) and includes ponds and floodplains. The lacustrine system includes all aquatic habitats situated in topographic depressions where wave-formed shoreline features form all or part of the boundary; or if such features are not present, where the deepest part of the catchment is at least 4 hectares (10 acres) in size and permanentiy devoid of trees, shrubs or persistent emergents. The riverine system includes all flowing water habitats terminated in the estuary (downstream) by salt water (greater than $500 \mathrm{ppm}$ total dissolved solids) or where the water becomes part of a lacustrine system. Again, definitions and descriptions of these systems must take into account seasonal variations in physiocochemical characteristics and concomitant changes in the biota.

Phytoplankton of palustrine and lacustrine systems are very diverse and productive, and are predominantly blue-green algae or diatoms, depending on the trophic state and/or time of year. The algae exert considerable influence on the rest of the system due to their photosynthesis, respiration and eventual decay. Phytoplankton in riverine habitats are predominantly diatoms and green algae, with seasonal pulses of biue-greens. Diversity is generally high, but biomass is lower than in other aquatic ecosystems, especially in turbid waters. Vascular plants in lacustrine and palustrine habitats are much more diverse than in estuarine waters. In ponds, Eleocharis, Utricularia, duckweeds, Najas, water hyacinth, Cabomba, and others are abundant. In lakes, Myriophyllum, Ceratophyllum, Cabomba, water hyacinth, and alligator weed dominate. Vascular vegetation in large rivers is rare but the shore can support willows and grasses.

Zooplankton of fresh-water ecosystems are comprised largely of cladocerans, copepods, rotifers and protozoans. Macrobenthos of ponds and 
lakes are dominated by tubificid worms, phanton midges, chironomid midges, and clams. Benthic macroinvertebrates in riverine systems are predominantly mayflies, Tortopus and Pentagenia, and clams of the genera Corbicula and Sphaerium, as well as tubificids, chironomids and amphipods.

The economically important river shrimp and crawfishes are also abundant in Targe rivers and in the palustrine habitats of Louisiana. Important fresh-water fishes are the largemouth bass, black crappie, redear sunfish, bluegill, smallmouth buffalo, carp, fresh-water drum, blue and channel catfish, spotted gar and bowfin. Loulsiana's waters support the largest inland fisheries in the nation and most of this habitat is near the coast. This production is directly related to the close association between open water areas such as the fresh-water ecosystems described here, and the overflow swamps, which provide nursery and feeding areas. Other vertebrates of importance include numerous amphibians, turtles, water snakes (including water moccasin), alligator, nutria, beaver, muskrat, and water fowl. Because Louisiana is located at the southern end of the Mississippi flyway, the annual migration of duck and geese make the effective management of these fresh-water ecosystems of international importance. An endangered species that nests close to fresh-water ecosystems is the southern bald eagle. Saline Marsh Ecosystem. The saline marsh is defined as an emergent vegetated wetland system subject to tidal fluctuations of salt water (greater than $500 \mathrm{ppm}$ total dissolved solids). This definition includes Chabreck's saline, brackish, and intermediate marshes (Chabreck, 1972), which encompass approximately 680,000 hectares $(1,680,000$ acres) in Louisiana (Figure VII-A-2, in Section VII).

The saline marsh is dominated by a small number of emergent vascular plants including Spartina alternafiora, Spartina patens, Distichl is spicata, and Juncus roemerianus. The greater the distance from the Gulf, the 
greater the species diversity of emergent plants in saline marshes. Epiphytic and benthic algae may also be an important component of this system. Most of the consumer foodweb is based on detrital breakdown. Insects, snails, fiddler crabs, polychaetes, copepods, mites, nematodes, mussles, and spiders are important invertebrates. Fishes associated with the saline marshes include menhaden, sheepshead, spot, and croaker. Redfish and spotted sea-trout are seasonally abundant. Economically important invertebrates are shrimp and blue crabs. There are few amphibians, but at least 16 species of reptiles, including the threatened American alligator, are found in saline marshes. Mammals include racoon, opossum, armadillo, swamp rabbit, marsh rice rats, muskrats and river otters, and the endangered red wolf. Birds include 79 species including the endangered brown pelican, and Peregrine falcon. The saline marshes provide wintering or nesting grounds for millions of egrets, herons, and ibis.

The detritus export function of saline marshes not only supports onsite productivity of economically and biologically important animals, but also supports much of the estuarine and marine productivity of Louisiana. Tidal and riverine flushing actions export detritus into estuaries where productive foodwebs exist.

Fresh Marsh Ecosystem. The fresh marsh ecosystem, encompassing about 316,000 hectares $(779,000$ acres) in Louisiana, includes vegetated habitats consisting mainly of herbaceous plants which are subject to being flooded with fresh water all or part of the year (Figure VII-A-2, in Section VIII). Floating or emergent hydrophytes found in this ecosystem are more diverse and are found in more complex associations than those of the saline marshes. Chabreck(1970) lists 93 species of vascular plants in the fresh marsh 
ecosystem. Maidencane is the dominant fresh marsh plant. Other vascular species are wiregrass, bulltongue, spikerush, alligator weed, duckweed, and water hyacinth. The primary productivity of these systems may be just as great as in saline marshes, but since there is little detrital export from the system and since there is no cyclic flushing from tides, comparatively little of that productivity is transfered to outside consumer levels. However, consumer diversity within the fresh marsh can be very great. Invertebrates such as insects, spiders, amphipods, isopods, tubificids, and fingernail clams can be found. Amphibians and reptiles are very diverse in these areas, whereas birds are less diverse than in saline marsh areas. Birds include wrens, egrets, blackbirds, bitterns, gallinules, herons, egrets, and hawks. Most duck species seem to prefer fresh marsh plants to saline marsh vegetation. Nutria is the most abundant mammal, but mink, racoon, deer, and rabbits are also important. Fishes in fresh marshes are usually limited to those areas in close proximity to open water. The edge between the marsh and open water can support many of the larger fish species described in the discussion on freshwater ecosystems. Oniy forms such as mosquito fish, topminnows, and small sunfishes are abundant in the densly vegetated regions of fresh marshes.

Ridge Ecosystems. Ridge ecosystems are isolated systems of higher ground within fresh or saline marsh ecosystems. These areas include beaches, cheniers, natural and artificial levees, pleistocene islands, salt domes, spoli banks and Indian mounds. Each of these natural or artificial habitats has its own distinct community of organisms. Furthermore, the geographical location of the individual area determines the blota. Ridges are surrounded by other wetland ecosystem, with the characteristics of that ridge dependent on the adjacent ecosystem. for instance, cheniers 
are found only in the western fresh and saline marshes while beaches are found along the coast near marine, estuarine and saline marsh areas. However, all these regions serve as refugia or landfalls for terrestial organisms. For example, during storm tides manmals and reptiles use the high ground until the water receeds. These ecosystems also provide landfalls for birds migrating across the Gulf and nesting sites for many species of birds.

Beaches are found along barrier islands of the Louisiana coast adjacent to the marine ecosystem and the saline marsh and estuarine ecosystems. Beaches serve to protect more productive inland areas from the erosive force of the marine environment. The plants which stabilize the beaches and dunes include some salt marsh species as well as some species unique to beaches. Amphibians, reptiles, and mammals are not diverse, but large numbers and species of birds either feed or nest along beaches. Invertebrates along beaches in the flooded sand are mainly meiofauna and some macrofauna such as clams, crabs, and other crustacea. Terrestrial animals are few.

Cheniers are abandoned beaches located inland (Figure VII-A-3, in Section VII). They are more stable and mature habitats than beaches, however, and consequently have different communities. Cheniers are used intensively for houses, agriculture and transportation so little of the natural vegetation remains. Where undisturbed, natural vegetation includes live oak, hackberry, elm, swamp maple, cypress, water locust, water oak, and numerous understory species. The chenier's main ecological value is as a landfall, especially in rough weather, for migrating bitds. Without these isolated strands, many would perish before reaching the uplands. 
Salt domes are unique geological features of which the "Five Islands" domes are most conspicuous in the area of interest for geopressured resource deveTopment (Figure VII-A-3). With elevations of over 100 feet above sea level, these domes stand high above the surrounding marsh. The vegetation ranges from typical marsh vegetation to typical upland associations not found in any other ridge habitat. Hardwoods such as butternut hickory, pecan, pignut hickory, southern magnolia, and live oak can be found. The islands are important wading bird rookeries and habitats for white tailed deer, small mammals, and possibly black bear. All of the "Five Islands" domes are mined for salt; several other domes in the study area are used to store crude oil as part of the strategic oil reserve program.

Artificial ridges such as levees, spoil banks, and Indian mounds are usually lower in elevation than natural ridges, but, because of their extent and economic and cultural significance, are important features. The levees are often maintained for grazing, but when allowed to succeed naturally, they revert to the flora of natural levees: Geranium carolinlanum, Cynoden dactylon, Paspalum dilatatum, Sorghum halepense and Sporobolus porirette. Vegetation on spoil banks in the marshes is predominantly spartina patens, Baccharis hal imifolia, Phragmites communis, Eupatorium serotinum.

In all of these inland ridge habitats, there is a diverse assemblage of invertebrate consumers: insects, spiders, mites, centipedes, snails, 01 igochaetes and nematodes. Amphibian and reptile forms can be found in ridge areas which are not found in the surrounding marshes. Bird communities, aside from transients, include a diverse number which either nest or overwinter. Mammals include eastern mole, shrews, cottontail rabbit, squirrels, fox, bobcats, and bats. Endangered or rare species found in 
the ridge habitats include sea turtles, the brown pelican, Bachman's warbler and the Peregrine falcon.

Bottomland Forest. The bottomland forest ecosystem includes all areas with woody vegetative cover flooded by fresh water all or part of the year (shown as cypress forests and two types of bottomland hardwoods in Figure VII-A-4, in Section VII). Two subsystems are recognized: cypress swamp forests dominated by bald cypress and tupelo gum; and the dryer bottomland hardwood forest dominated by trees such as pecan, buttonbush, mayhew, hawthorn, ash, water locust, Virginia willow, tupelo gum, swamp cottonwood, and others. Cypress swamps serve as important overflow habitats for fish spawning and crawfish production. Bottomland hardwood forests also serve these purposes, but in addition support significant production of game animals: deer, squirrel, rabbit, racoon, opossum, fox, bear, woodcock, ducks, wading birds and others.

Typically, it is these overflow habitats which support the productivity of the fresh-water ecosystems in Louisiana. When a waterway is isolated from its floodplain by levees, the production of fishes goes down and game fishes are replaced by undesirable fishes. The yearly flooding of these areas in the spring inundates detritus, annuals, and understory shrubs from the previous growing season. 


\section{TERRESTIAL ECOSYSTEMS}

Prairie Ecosystem. This system is defined as a terrestrial upland system which is naturally dominated by grasses. When first settled, this ecosystem was dominated by tall grasses--mainly species of Andropogon and Panicum. After the initial clearing and grazing of these tall grasses, the system did not revert to its natural state, but is now dominated by other grass species as well as numerous weedy herbs. Eleven species of amphibians and many reptiles including turtles and snakes are common to this ecosystem. The water snake Natrix is notable by its absence. Geese are the dominant game animal in this habitat. Other birds found in prairies are the eastern meadowlark, American kestrel, snipes, dove, and some ducks. There are at least 24 species of mamals naturally occurring, including the endangered red wolf. The invertebrates of the prairie are mainly insects and worms.

Upland Forest Ecosystem. The upland forests are defined as terrestrial systems located on the Pleistocene terrace and dominated by hardwood or pine trees. Two subsystems are recognized in south Louisiana. The hardwood system includes oak, gum, ash, hickory, poplar, maple, beech, magnolia, black cherry, dogwood, redbud and hayhaw. The flatwoods system is dominated by long leaf pines, wiregrass, palmetto and some hardwoods, including scrub oaks. Birds are very diverse in hardwood forests and less so in flatwood forests. Bald eagles nest in tall dead hardwoods but no known nests are presently found in this ecosystem. Other birds include herons, egrets, owls, woodpeckers, hawks, warblers, crows, blackbirds, the belted kingfisher, and the game birds--ducks, quail and turkey. Mammals include 
squirrel, rabbits, opossum, shrews, moles, bats, armadillo, mice, rats, and skunks. Important game mammals include deer, fox, bear, squirrels, and rabbits. Reptiles commonly found in upland forest are lizards, snakes, and turtles; amphibians include frogs, toads, and salamanders. Terrestrial arthropods are important invertebrate consumers in upland areas and are often in very great diversity. 
APPENDIX B

Summary of Consultations with Interested Groups 
U

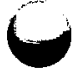




\section{SUMMARY OF CONSULTATIONS WITH INTERESTED GROUPS}

Representatives of industry, regulatory, and research groups were consulted during the course of this research in order to obtain input on key environmental issues. These groups were selected according to specific criteria. Industry representatives were identified on the basis of a strong interest in geopressured resource development on the part of the company. Regulatory agencies which will have an active role in the environmental regulation of geopressured resource development activities were visited. Research organizations and individuals with work in progress that directly concerns geopressured resource development or the environmental setting of the study area were consulted.

Consultations with these groups were conducted as interviews and, in the case of the U. S. Department of Energy/Industry Geopressure Geothermal Advisory Group, Environmental/Laboratory Research Working Subgroup, during the course of periodic group meetings. This group was specially convened on April 26, 1978 to review the results of the LSU study. The full day meeting was very productive in terms of feedback on the research results, and this Report was revised on the basis of comments made at that time. A list of participants in this meeting is appended to this section.

A list of the organizations and individuals consulted in individual sessions is given below.

\section{INDUSTRY}

Industry input in identifying key environmental issues was considered very important in order to insure that due significance was ascribed to those issues. Industries covering the full range of functions expected of geopressured operations were contacted. Of those companies listed 
below, two are primarily involved in exploration and resource extraction (Magma Gulf Co. and Systems Fuels); one is a pipeline company (United Gas Pipeline Co.); and one is a privately owned electric utility (Gulf States Utility Co.). Middle South Services, Inc. is a planning group for Middle South Utilities, an electric utility with a service territory that includes large portions of southeastern Louisiana. The other companies listed also operate within the study area in Louisiana, and have shown an active interest in geopressured resource development.

Gulf States Utilities Company

P.0. Box 2951

Beaumont, Texas 77704

Representative: A. J. Champagne, Director, Nuclear Services

Magma Gulf Company

Box 65017

Baton Rouge, Louisiana 70896

Representatives: C. 0. Durham, Jr., President; W. A Romans, Vice President

Middle South Services, Inc. (a subsidiary of Middle South Utilities, Inc.) Box 51000

New Orleans, Louisiana 70161

Representative: L. A. Wilson, Manager; Advanced Energy Programs

Systems Fuels, Inc. (a subsidiary of Middle South Utilities, Inc.)

Box 61532

New Orleans, Louisiana 70161

Representative: R. A. Rust, Vice President for Exploration

United Gas Pipeline Company

P.0. Box 1478

Houston, Texas 77001

Representative: R. Christopher, Director of Research

\section{GOVERNMENT AGENCIES}

Representatives of state agencies with regulatory responsibilities either over geopressured operations specifically, or special regulatory functions and concerns in the study area, were contacted. The objective was to determine the regulatory particulars of potential environmental 
problems and to obtain input on the relative significance of environmental issues.

Specific regulations and agency functions are discussed where appropriate in the main body of the report. The following paragraphs summarize this information.

The Department of Natural Resources, Office of Conservation has general regulatory authority over geopressured development activities. In the environmental area, the Office of Conservation will regulate the subsurface disposal of geopressured fluids and other wastes. The intent of the proposed regulations on subsurface disposal is to protect fresh or brackish water aquifers, to protect hydrocarbon production from the sands into which geopressured fiuids are injected, and to insure that completion procedures are adequate so that leakage will be minimized. The Commissioner's proposed rules on geopressured resource development also include a provision requiring baseline data collection and subsidence monitoring.

The Department of Wildlife and Fisheries has general authority for the protection of wildlife and aquatic life and for certain areas of water quality. Of interest for the future development of geopressured resources, the Department of Wildlife and Fisheries has responsibility in the following areas through its offices.

1. The Office of Coastal and Marine Resources administers programs relating to oysters and other benthic species including regulation of waste disposal into surface waters that might have adverse effects on these important commercial species.

2. The Stream Control Commission controls all disposal into surface waters. The Stream Control Commission has the authority to promulgate and enforce water quality standards. 
3. The Office of Wildlife administers state wildlife refuges and State wildiife management areas. There are a number of these in the area of geopressured resource interest in Louisiana. $0 i 1$ and gas production does take place on. State refuges and wildlife management areas, with production practices regulated by the Office of Wildlife to insure the protection of wildlife.

The Louisiana Air Control Commission has authority to promulgate air quality standards and to ensure that these are enforced. The Commission monitors compliance with federa1 air quality standards.

The U.S. Army Corp of Engineers regulates the disposal of dredged or fill materials in wetlands and waterways generated for any purpose unless expressly excluded by Congress. Disposal of material dredged during oil and gas field operation--both in wetlands and offshore--is regulated by the Corps.

The U.S. Department of Energy administers the Strategic Petroleum Reserve Program in which several salt domes in the area will be used for oil storage. Representatives of the Program were contacted to learn of their experience with the subsurface disposal of brines stored in salt dome cavities. Subsurface disposal of brines from solution mining activities is anticipated in the Program.

Louisiana Department of Health and Human Resources, Louisiana Air Control Commission

P.0. Box 60630

New Orleans, Louisiana 70160

Representatives: J. F. Coerver, Director Environmental Services;

G. VonBodunden, Air Qualtiy Section

Louisiana Department of Natural Resources

Office of Conservation

P.0. Box 44275

Captiol Station

Baton Rouge, Louisiana 70804

Representatives: A. C. Chauviere, Jr., Assistant Commissioner of Conservation;

R. Bates, Chief Geologist; C. King, Assistant Chief Geologist; J. Adams, Geologist; C. Decker, Permit Section. 
Louisiana Department of Wildlife and Fisheries

Office of Coastal and Marine Resources

400 Royal Street:

New Orleans, Louisiana 70130

Representative: L. St.Amant, Assistant Secretary

Louisiana Department of Wildlife and Fisheries

Office of Wildiife

P.0. Box 44095

Capitol Station

Baton Rouge, Louisiana 70804

Representatives: J. Herring, Chief, Game Division; K. Smith, Chief, Division of Fisheries.

Louisiana Department of Wildlife and Fisheries

Stream Control Commission

P.0. Drawer FC

University Station

Baton Rouge, Louisiana 70803

Representative: R. A. Lafleur, Exec. Secretary

U. S. Army Corps of Engineers

New Orleans District

P.0. Box 60267

New Orleans, Louisiana 70160

Representative: H. Beckert, Biologist, Environmental Section

U. S. Department of Energy

Strategic Petroleum Reserve Program

900 Commerce Road, East

New Orleans, Louisiana 70123

Representative: C. Everette, Operations Manager, Bayou Choctaw Strategic Petroleum Reserve Program

\section{RESEARCH ORGANIZATIONS}

Research groups with special interests in either the environment of the study area or geopressured resource development were contacted. These groups provided both technical information and input on the relative significance of potential environmental problems. Coastal Environments, Inc. has completed and on-going contracts with DGE in the area of environment impacts of geopressured testing activities. Professor Harre11, Director of the LSU Mineral Law Institute, is the Principal Investigator of a research project for DGE on legal aspects of the development of 
geopressured resources in Louisiana. Professor Bernard of the LSU Petroleum Engineering Department is Principal Investigator of a project for DGE to perform the resource assessment of geopressured prospects in Louisiana. The LSU Center of Wetland Resources has completed a number of research projects on environmental characteristics and impacts in the Louisiana coastal region. The Coastal Resources Program in the State Planning Office provides technical assistance to the state for the formulation of legislation in support of the National Coastal Zone Management Act of 1972. The act calls for states to develop a comprehensive plan regulating the use to which coastal lands may be put. Mr. Waguespack, LSU Office of Advanced Studies and Research, coordinated an operations research project on geopressured resource developemnt in Louisiana.

Center for Wetland Resources

124 Wetland Resources Bldg. Louisiana State University

Baton Rouge, Louisiana 70803

Representative: J. G. Gosselink, Professor, Marine Sciences

Coastal Environments, Inc. 1260 Main Street

Baton Rouge, Louisiana 70802

Representatives: R. E. Emmer, Senior Associate; C. Wax, Associate

Louisiana State Planning Office

Coastal Resources Program

P.0. Box 44425

Capitol Station

Baton Rouge, Louisiana 70804

Representative: P. H. Templet, Program Coordinator

Louisiana State University

Office of Advanced Studies and Research

324 Chemical Engineering

Louisiana State University

Baton Rouge, Louisiana 70803

Representative: M. 0. Waguespack, Senior Research Associate

Louisiana State University

Petroleum Engineering Department

121 Geology Building

Louisiana State University

Baton Rouge, Louisiana 70803

Representative: W. J. Bernard, Professor 


\section{CONSULTANTS}

Several experts at. LSU were consulted on a number of technical points. Dr. Lewis provided information on remote sensing data and techniques. Mr. Hawkins and Dr. Thoms consulted on engineering questions. Or. Noble reviewed the sections of the Report dealing with natural vegetation, and $\mathrm{Mr}$. Smith consulted on ground-water considerations.

Anthony J. Lewis, Associate Professor Department of Geography and Anthropology Louisiana State University

Murray F. Hawkins, Project Engineer Institute for Environmental Studies. Louisiana State University

Robert E. Noble, Associate Professor School of Forestry and Wildlife Management Louisiana State University

Eharles G. Smith, Jr. Consultant Geologist Baton Rouge, Louisiana

Robert $L$. Thoms, Professor of Civil Engineering Institute for Environmental Studies

Louisiana State University 
ATTENDEES OF THE FOURTH MEETING OF THE ENVIRONMENTAL/LABORATORY RESEARCH WORKING SUBGROUP -DOE/INDUSTRY GEOPRESSURED GEOTHERMAL RESOURCE DEVELOPMENT PROGRAM

Ramada Inn, New Orleans, Louisiana. April 26, 1978

Ann Bachman

Research Associate

Institute for Environmental Studies

42 Atkinson Hall

Louisiana State University

Baton Rouge, Louisiana 70803

(504) 388-6946

John I. Bailey

Graduate Assistant

Department of Geography

Institute for Environmental Studies

Louisiana State University

Baton Rouge, Louisiana 70803

(504) 344-6039

Rich Bennett

Research Engineer

Columbia Gas System

Research Department

1600 Dublin Road

Columbus, Ohio 43215

(614) 486-3681

Charles R. Boardman

Geologist

C.K. GeoEnergy Corp.

5030 Paradise Road, Suite Al03

Las Vegas, Nevada 89119

(702) $739-9630$

James D. Chiti

Engineer-Energy Resources

Peoples Gas System

122 S. Michigan

Chicago, Illinois

(312) $431-7994$

Arnold C. Chauviere

Louisiana Office of Conservation

P. O. Box 44275

Baton Rouge, Louisiana 70808

(504) 389-5161
Ray Chavanne

McNeese State University

Chemistry Department

Lake Charles, Louisiana 70601

(318) 477-2520 Ext. 438

Bob Christopher

Director Development Admin.

United Gas Pipeline Co.

Box 1478

Houston, Texas 77073

(713) $237-4440$

Hank Coffer

C. K. GeoEnergy Corp.

5030 Paradise Road, Suite Al03

Las Vegas, Nevada 89119

(702) $739-9630$

Neil Crow

Geologist

Lawrence Livermore Laboratory P. O. Box 808

Livermore, California 94550

(415) 846-6877

Kevin Cunningham

Graduate Assistant

Louisiana State University

Institute for Environmental

Studies

42 Atkins on Hall

Baton Rouge, Louisiana 70803 (504) $388-8521$

D. A. Danielson

Senior Project Geologist

Texaco, Inc.

Box 60252

New Orleans, Louisiana 70160

(504) 524-8511

Grant S. Darnell

Engineer

Amoco Production Company

P. O. Box 50874

New Orleans, Louisiana 70150

(504) $586-6250$ 
ATTENDEES OF THE FOURTH MEETING OF THE ENVIRONMENTAL/LABORATORY RESEARCH WORKIIG SUBGROUP - DOE/INDUSTRY GEOPRESSURED GEOTHERMAL RESOURCE DEVELOPMENT PROGRAM

Ramada Inn, New Orleans, Louisiana April 26, 1978

R. J. Dobson

Vice President

Gruy Federal, Inc.

2500 Tanglewilde

Houston, Texas 77063

(713) $785-9200$

Rod E. Emmer

Coastal Environments, Inc.

Senior Associate

1260 Main Street

Baton Rouge, Louisiana 70802

(504) 38307455

Richard Epstein, Attorney

Amoco Production Company

P. O. Box 50879

New Orleans, Louisiana 70150

(504) 586-6671

Ernest C. Greer

Chemical Engineer

Transco Energy Co.

Box 1396

Houston, Texas 77001

(713) $626-8100$

Doug Gundy

Senior Petroleum Engineer

Tenneco Oil Co.

P. O. Box 2511

Houston, Texas 77001

(713) $757-2558$

Russell Ham

Chemistry Department

McNeese State University

Lake Charles, Louisiana 70609

(318) 477-2520 Est. 411

Jack Hamilton

District Geologist

Dow Chemical Company

Box 22468

Houston, Texas 77027

(713) $623-3144$
Doug Harrison

Department of Chenical Engineering

Louisiana State University

Baton Rouge, Louisiana 70803

(504) $388-1426$

Robert P. Hartley

Physical Scientist

U. S. Environmental Protection Agency

Industrial Environmental Research Laboratory

Cincinnati, Ohio 45268

(514) $684-4335$

Jim Hartsock

Senior Engineer

Gruy Federal, Inc.

2500 Tanglewilde

Houston, Texas 77063

(713) $623-0300$

George Higgins

Research Engineer

Dow Chemical Company

Building 566

Midland, Michigan 48640

(577) $636-6773$

Calvin D. Jackson

Department of Energy

San Francisco Operations

1333 Broadway

Oakland, California 94612

(415) $273-7963$ 
ATTENDEES OF THE FOURTH MEETING OF THE ENVIRONMENTAI/LABORATORY RESEARCH WORRING SUBGROUP - DOE/INDUSTRY GEOPRESSURED GEOTHERMAL RESOURCE DEVELOPMENT PROGRAM

Ramada Inn, New Orleans, Louisiana April 26, 1978

C. F. Knutson

C. K. GeoEnergy

5030 Paradise Rd. Suite Al03

Las Vegas, Nevada 89119

(702) $739-9630$

Michael Kohn

American Cyanamid Co. 10800 River Road.

West Wego, Louisiana

(504) 729-5511

Ed Luper

Subsurface Geologist

Mississippi Geology Survey

P. O. Box 4915

Jackson, Mississippi 39216.

(601) $354-6228$

Donald G. McCubbin

Research Geologist

Marathon Oil Company

Denver Research Center

Box 269

Littleton, Co. 80122

(303) 794-2601

Robert A. Muller

Professor of Climatology

Institute-Environmental Studies

Louisiana State University

Baton Rouge, Louisiana 70803

(504) 388-5942

Ed Newchurch

Professor

Institute for Environmental

Studies

42 Atkinson Hall

Louisiana State University

Baton Rouge, Louisiana 70803

(504) $388-8521$
Preston Newman

Research Associate

Institute for Environmental Studies

Louisiana State University

Baton Rouge, Louisiana 70803

(504) 388-6051

Martin Novil

Assistant Engineer Economist

Institute of Gas Technology

3424 S. State Street

Chicago, Illinois 60613

(312) $567-3674$

R. L. Randolph, Associate Director

Institute of Gas Technology

3424 So. State Street

Chicago, IIlinois 60616

(312) $567-3766$

Stuart Richardson

Senior Environmentalist

Ecology and Environment

P. O. Box D

Buffalo, New York 14225

(716) 655-0252

Robert H. Roberts

Manager Mechanical Engineering Development

Pullman/Kellogg

16200 Park Row

Industrial Park 10

Houston, Texas 77084

(713) $492-2500$

William A. Romane

Magma Gulf Co.

Box 65011

Baton Rouge, Louisiana 70896

(504) 926-8144 
ATTENDEES OF THE FOURTH MEETING OF THE ENVIRONMENTAL/LABORATORY RESEARCH WORKING SUBGROUP - DOE/INDUSTRY GEOPRESSURED GEOTHERMAL RESOURCE DEVELOPMENT PROGRAM

Ramada Inn, New Orleans, Louisiana

$$
\text { April 26, } 1978
$$

A. E. Schlemmer

Texas Eastern Transmission Corp.

P. 0. Box 2521

Houston, Texas 77001

(713) $651-8100$ Ext. 507

Caralee J. Spencer

Office Manager

C.K. GeoEnergy

5030 Paradise Rd. Suite AI03

Las Vegas, Nevada 89119

(702) $739-9630$

Glenn Suter

Research Associate

Oak Ridge National Laboratory

P. 0. Box X

Oak Ridge, Tn. $\quad 37830$

Keith Westhusing

Program Manager

Department of Energy

Division of Geothermal Energy

20 Massachusetts Avenue

Washington, D. C. 10545

(202) 796-9600

Ernest Williams

Laboratory Manager

Weintritt Testing Labs.

P. 0. Box 30162

Lafayette, Louisiana

(318) $981-1560$

Ronald E. Wilcox

Associate Professor

Institute for Environmental

Studies

Louisiana State University

Baton Rouge, Louisiana 70803

(504) $388-6946$
John S. Wilson

Dow Chemical Company

Texas Division

Building A 2301

Freeport, Texas 77541

(713) $238-4153$ 